UNIVERSIDADE DE SÃO PAULO

ESCOLA DE COMUNICAÇÕES E ARTES

NINA NUSSENZWEIG HOTIMSKY

O trabalho de encenação em Calabar (1973):

o espetáculo censurado e as reflexões de Fernando Peixoto

São Paulo

2019 
O trabalho de encenação em Calabar (1973):

o espetáculo censurado e as reflexões de Fernando Peixoto

Dissertação apresentada ao Programa de Pós-Graduação em Artes Cênicas da Escola de Comunicações e Artes da Universidade de São Paulo, para a obtenção do Título de Mestre em Artes.

Área de Concentração: Teoria e Prática do Teatro. Orientador: Prof. Dr. Sérgio Ricardo de Carvalho Santos.

São Paulo

2019 
Autorizo a reprodução e divulgação total ou parcial deste trabalho, por qualquer meio convencional ou eletrônico, para fins de estudo e pesquisa, desde que citada a fonte.

Catalogação na Publicação

Serviço de Biblioteca e Documentação

Escola de Comunicações e Artes da Universidade de São Paulo

Dados inseridos pelo(a) autor(a)

Hotimsky, Nina Nussenzweig

o trabalho de encenação em Calabar (1973): o espetáculo

censurado e as reflexões de Fernando Peixoto / Nina

Nussenzweig Hotimsky ; orientador, Sérgio Ricardo de

Carvalho Santos. -- São Paulo, 2019.

233 p.: il.

Dissertação (Mestrado) - Programa de Pós-Graduação em Artes

Cênicas - Escola de Comunicações e Artes / Universidade de

São Paulo.

Bibliografia

Versão original

1. Fernando Peixoto 2. Chico Buarque de Hollanda 3. Ruy Guerra 4. Teatro Musical Politizado 5. Teatro Brasileiro I. Santos, Sérgio Ricardo de Carvalho II. Título.

CDD 21.ed. - 792 
Nome: HOTIMSKY, Nina Nussenzweig.

Título: O trabalho de encenação em Calabar (1973): o espetáculo censurado e as reflexões de Fernando Peixoto.

Dissertação apresentada ao Programa de Pós-Graduação em

Artes Cênicas da Escola de Comunicações e Artes da Universidade de São Paulo, para a obtenção do Título de Mestre em Artes.

Área de Concentração: Teoria e Prática do Teatro. Orientador: Prof. Dr. Sérgio Ricardo de Carvalho Santos.

Aprovada em:

Banca Examinadora:

Prof. Dr. Instituição

Julgamento Assinatura

Prof. Dr. Instituição

Julgamento Assinatura

Prof. Dr. Instituição

Julgamento Assinatura 
Para Sonia e Silvio,

E para Rafael, com amor. 


\section{AGRADECIMENTOS}

Agradeço a Sonia e ao Silvio, meus pais, pelas leituras de agora e pelas leituras de antes: leituras, canções e conversas que me formaram.

Agradeço ao Rafael, companheiro de vida, pela força e alegria de todos os dias. Pela troca de ideias e pelo descanso compartilhado. Amo você.

Agradeço ao avô Victor pela paixão pela pesquisa, e à avó Nechama pelo cotidiano amoroso. A Ruth e a Mark, na memória - conviver com avós é um outro jeito de se interessar pela História.

Ao meu irmão, vizinho e amigo, Marcelo. E à sua companheira, Julia, que trouxe novas alegrias para o bairro.

Agradeço à família do Rafa, família que ganhei. Que sorte fazer parte dos aniversários e dos debates políticos! E um agradecimento especial a Herci e Marília pelas conversas sobre a opção brasileira.

Agradeço às amigas e amigos. Fernanda, pelas prosas maravilhosas e por me lembrar de descansar. Leticia, por ser tão próxima mesmo quando tão distante. Clara, por me dar coragem de escrever e de enfrentar as burocracias. Amanda, pelas peças e passeios. Parceiros do CAC 08, pelos bons encontros: queridos Paulet, Carú, Amandona, Tai, Tutti, Chico, Nat. A Laura e Raonna, mulheres, pesquisadoras e parsas admiráveis. Lira, que une arte, educação e luta. Hique e Pedro, pela praia. Gustavo por Um grito parado no ar. Natália Quadros, pelo canto em cena - aprendo muito com você.

Agradeço a ETEC de Artes por ter concedido o afastamento durante a vigência da bolsa de mestrado.

Aos artistas educadores da ETEC, que me apoiaram nessa fase de estudos. Parceiros com quem me alegro de voltar a trabalhar! Agradeço especialmente aos colegas que toparam transições atípicas de componente para permitir que eu aceitasse a bolsa. Muito obrigada Lana, Élder, Valmir, Peticia, Fabi e Kel.

Agradeço aos estudantes da ETEC de Artes, pelas ótimas perguntas e pela paixão. Faz mais sentido estudar para dar aula para vocês.

Agradeço aos artistas da Cia. do Latão. Trabalhar com vocês me ensina e me emociona muito. Muito mesmo. Agradeço a Helena e ao Ney pela generosidade imensa e cotidiana e pelas lindas letras das canções. Agradeço a Cau Karam, parceiro de música 
em cena, tão bom na viola quanto no jeito de existir. Agradeço a Érika, Maria Lívia, Bia, João, Lucas, Ademir, Gabriel, Ricardo, Alessandra, Leo, Carlos, João Pissarra, Natália, Bruno, João Maria. Que sorte esses encontros!

Agradeço ao professor Guilherme Ribeiro, que me mostrou que a sanfona continuaria existindo mesmo durante o mestrado.

Agradeço à Beá e Guilherme, que me abrigaram no Rio de Janeiro quando eu fui pesquisar pela primeira vez - e alimentaram a alegria de cada descoberta durante aquela semana decisiva.

A Ana Saramago, que trabalhava no Arquivo Fernando Peixoto fazendo questão de cumprir o seu papel social: ser fonte de pesquisa. Ao Rodrigo, que encontrou as fitas que analiso - sem você esse texto seria impossível.

Agradeço a Kleber Montanheiro e aos artistas que trabalharam comigo na Cia. da Revista, onde descobri que teatro e música andariam juntos.

A Sandra Grasso, que me apresentou Brecht.

Aos parceiros do LITS, pelas muitas ajudas e pela troca de ideias. Agradeço a Lu Gabriel (parceira de viagem!), Paulo Bio (grata pela paciência com tantas perguntas!), Sara, Maria Lívia, Érika, Beatriz, Ademir, Paula Autran, Paulo Fávari, Mari, Olga, Álvaro.

A todos as pessoas que cederam entrevistas para essa pesquisa: Mário Masetti (in memoriam), Ruy Guerra, Dori Caymmi, Carlos Chaves, Renato Laforet, Nina de Pádua, Anselmo Vasconcelos, Imara Reis, Marcus Vinicius, Sérgio Mamberti e Herbert Richers Júnior. Muito obrigada por compartilhar suas memórias e suas ideias! Só foi possível escrever conversando com vocês.

Agradeço a Vavy Pacheco Borges e a Mariana Mayor, que permitiram que acontecesse a entrevista com o Ruy Guerra.

Às bibliotecárias da ECA, Marina Macambyra e Lilian Viana, pela paciência ao me orientar com referências pouco tradicionais.

Agradeço aos professores Silvia Fernandes e Walter Garcia, pelas preciosas sugestões durante o exame de qualificação desse trabalho. E ao professor Alexandre Flory, que aceitou vir de longe para compor a banca.

Agradeço à FAPESP e à CAPES pela bolsa que permitiu o desenvolvimento desse trabalho. Processo no 2017/19467-7, Fundação de Amparo à Pesquisa do Estado de São Paulo (FAPESP). As opiniões, hipóteses e conclusões ou recomendações expressas neste material são de responsabilidade dos autores e não necessariamente refletem a visão da FAPESP e da CAPES. 
Agradeço especialmente ao professor Sérgio de Carvalho, pela orientação inteligente e sensível e pelas aulas desde 2008. Por ter escrito e dirigido espetáculos que me formaram, e pelas trocas teatrais e musicais recentes. Por ter me orientado desde a iniciação científica e, com o passar do tempo, me incentivar a escrever o que penso. E por, como Fernando Peixoto, defender um final um pouco menos pessimista: sigamos em movimento. Muito obrigada, professor! 
HOTIMSKY, Nina Nussenzweig. O trabalho de encenação em Calabar (1973): o espetáculo censurado e as reflexões de Fernando Peixoto. Dissertação (Mestrado em Teoria e Prática do Teatro) - Escola de Comunicações e Artes, Universidade de São Paulo, 2019.

Este trabalho investiga a encenação censurada de Calabar. A peça foi escrita por Chico Buarque de Hollanda e Ruy Guerra em 1973, dirigida por Fernando Peixoto no mesmo ano, e censurada às vésperas da estreia pela Ditadura Civil-Militar. A pesquisa reuniu documentos ligados ao trabalho teatral realizado, incluindo depoimentos inéditos do período, gravados em fita cassete por Fernando Peixoto e pelo diretor assistente Mário Masetti. Foram também realizadas entrevistas com artistas que participaram do processo de ensaios. A partir desses materiais, foi produzida uma análise da montagem interrompida, organizada em três capítulos. O primeiro deles trata do processo de produção da peça. Muitas das reflexões de Peixoto sobre Calabar estão ligadas aos limites e possibilidades estabelecidos por sua forma de produção. O encenador avalia os impasses das produções teatrais de esquerda inseridas no circuito comercial. O segundo capítulo descreve e analisa o trabalho da equipe de direção sobre a dramaturgia. Peixoto e Masetti realizaram diversas reflexões sobre as potências do texto, e os pontos em que a montagem entrava em atrito com as proposições dramatúrgicas. Por fim, no terceiro capítulo, foram analisados aspectos da encenação censurada. Peixoto articulou um enunciado da encenação a partir da presença de um coro que representava o povo. Nele se projetava um vislumbre de luta popular, sem a presença de um herói. A participação do coro nessa montagem dialoga com certa tradição de teatro musical politizado da década de 1960, mas sua especificidade está ligada à conjuntura do Brasil da década de 1970. Ao estudar a encenação censurada de Calabar, essa pesquisa procurou investigar as relações entre forma cênica, condições produtivas e contexto histórico.

Palavras-chave: Fernando Peixoto; Chico Buarque de Hollanda; Ruy Guerra; teatro musical politizado; teatro brasileiro. 


\begin{abstract}
HOTIMSKY, Nina Nussenzweig. The process of staging Calabar (1973): the censured play and Fernando Peixoto's reflections on it. Dissertation (Master's Degree in Theater Theory and Practice) - Escola de Comunicações e Artes, Universidade de São Paulo, 2019.

This dissertation investigates the censured staging of Calabar. The play was written by Chico Buarque de Hollanda and Ruy Guerra in 1973 and directed by Fernando Peixoto the same year. It was censured a few days before of its debut by the Military-Civil Dictatorship. The research undertaken in this study assembled documents concerning the theatrical production, including unplublished testimonies from the period, recorded on audio tapes by Fernando Peixoto and his assistant director, Mario Masetti. Interviews with artists that participated in the process of rehearsals were also undertaken as a part of this investigation. Based on this material an analysis was produced of the interrupted theatrical production, organized in three parts. The first part deals with the process of producing the play. Many of Peixoto's reflections concerning Calabar are associated with the limits and possibilities established by its form of production. The director evaluates the obstacles of leftist theatrical productions enclosed within the commercial circuit. The second part describes and analyzes the rendering of the dramaturgy by the director's team. Peixoto and Masetti reflect upon the potentialities of the text and the aspects of the staging that conflict with the intentions of the dramaturgy. The third part is dedicated to the analysis of certain aspects of the censured staging of Calabar. Peixoto articulated a formulation of the staging in which a chorus that represented the people had an important role. This chorus was meant to project a glimpse of a popular struggle, undertaken in the absence of a hero. The participation of the chorus in this staging dialogues with a certain tradition of musical politicized theater of the sixties, but its specificity is associated with the particular Brazilian scenario of the seventies. Upon studying the censured staging of Calabar, this research sought to investigate the relations between the scenic form, conditions of production and the historical context within which this play was enacted.
\end{abstract}

Keywords: Fernando Peixoto; Chico Buarque de Hollanda; Ruy Guerra; musical politicized theater; brazilian theater. 


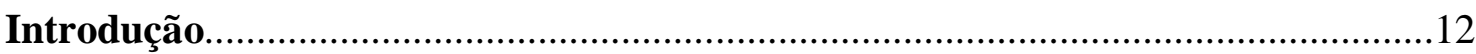

Capítulo 1 - Uma produção interrompida..............................................................43

Capítulo 2 - A dramaturgia de Calabar e as reflexões da equipe de direção...........72

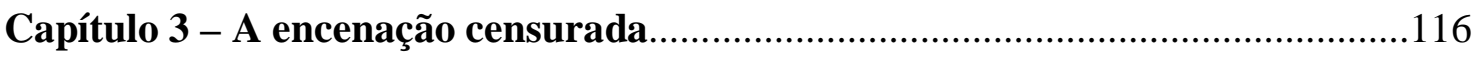

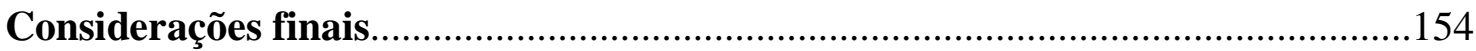

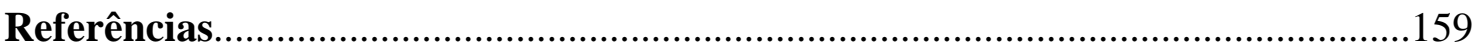

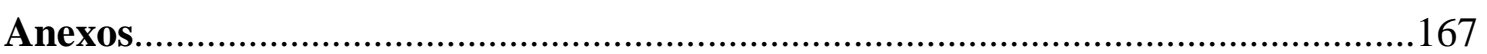




\section{Introdução}

$\underline{\text { As reflexões de Fernando Peixoto: esforços de memória e documentos de crise }}$

Em 13 de novembro de 1973 a produção de Calabar foi oficialmente desfeita. O espetáculo estava quase pronto, mas não lhe foi permitido estrear. Tratava-se da primeira montagem da dramaturgia de Chico Buarque de Hollanda e Ruy Guerra, escrita poucos meses antes. O texto foi liberado pela Divisão de Censura de Diversões Públicas (DCDP), e Fernando Peixoto dirigiu a encenação - uma superprodução que empregava cerca de oitenta trabalhadores. Às vésperas da estreia, a peça foi proibida pela Censura de maneira especialmente arbitrária, já que os protocolos oficiais não foram seguidos ${ }^{1}$.

Durante o mês de novembro, um plano de montar a peça na Argentina fracassou, e a Polícia Federal proibiu que se realizasse a filmagem de um ensaio geral - medida defensiva que visava "guardar o que foi feito” (PEIXOTO, 1989b, p. 192). Uma forma possível de registrar o trabalho teatral realizado foi gravar em fita cassete uma descrição e um estudo da montagem. Fernando Peixoto e Mário Masetti (encenador e diretor assistente) realizaram essa gravação um dia após a interrupção dos ensaios.

A iniciativa de registrar oralmente a encenação, descrevendo e comentando detalhadamente cada cena, foi uma expressão objetiva de resistência à censura. Enquanto o Estado brasileiro impedia que se mencionasse a palavra “Calabar” em quaisquer meios, a equipe de direção criava um documento com o máximo de detalhes que a forma oral permitia. Não se tratava de um puro elogio ao espetáculo. Pelo contrário: na fita registravam-se dúvidas, inacabamentos, caminhos apontados que não haviam sido suficientemente aprofundados. Se a peça continha esses problemas, para que o esforço em preservar sua memória? Talvez porque, em suas imperfeições e em suas potências, ela se tornara um testemunho importante do teatro brasileiro dos anos 1970 e das questões do país à época. Esse desejo de proteger o espetáculo do esquecimento também foi endossado pela boa vontade com a qual artistas envolvidos com a montagem se prontificaram a colaborar com o presente trabalho ${ }^{2}$.

\footnotetext{
${ }^{1}$ Detalhes sobre o processo censório serão descritos no capítulo 1 da presente dissertação.

${ }^{2}$ Entre 2016 e 2019 foram entrevistados oito trabalhadores envolvidos com o Calabar de 1973. Diversos entrevistados passaram o contato de outros artistas ligados à montagem, ampliando a rede de pessoas dispostas a narrar o processo criativo de Calabar. Foram entrevistados o diretor assistente Mário Masetti, o dramaturgo Ruy Guerra, os atores Imara Reis, Nina de Pádua e Anselmo Vasconcelos, o diretor musical
} 
A proposta inicial dessa pesquisa era reunir documentos e relatos sobre o trabalho teatral em torno da encenação censurada de Calabar, para em seguida analisar a montagem interrompida tecendo relações entre forma cênica, condições produtivas e contexto histórico. O primeiro artista entrevistado foi justamente o diretor assistente Mário Masetti, que chamou a atenção para a existência da fita de áudio com reflexões de Peixoto e dele mesmo sobre a peça. Havia uma menção a esse documento em um texto já publicado de Peixoto, extraído de seu caderno de direção: “14.11.1973 - Com Mário Masetti, gravo uma conversa crítica e autocrítica sobre o trabalho. Agora, fim. Acabou Calabar” (PEIXOTO, 1989b, p. 193).

De posse dessa informação, foi possível encontrar duas fitas cassetes relacionadas ao Calabar de $1973^{3}$ no Arquivo Fernando Peixoto (localizado no Centro de Documentação e Pesquisa da Funarte). As fitas localizadas contém três gravações ligadas à montagem. Uma delas é o diálogo entre Peixoto e Masetti. A segunda gravação é uma reflexão pessoal de Fernando Peixoto, realizada em 18 de novembro de 1973 (quatro dias após a gravação da conversa com Masetti), em que ele levanta perguntas sobre o próprio trabalho. A expressão mais frequente da fita é "até que ponto": Peixoto parece procurar balizas para avaliar sua direção, já que os espectadores e a crítica especializada não teriam chance de fazê-lo. Além disso, o encenador situa Calabar em relação a sua trajetória artística, e tenta avaliar quais deveriam ser os seus próximos passos. É um documento de crise: crise de um artista, crise do teatro brasileiro politizado, crise do país.

A terceira gravação é de autoria de Chico Buarque. O dramaturgo e compositor executa as canções de Calabar de maneira simples, apenas com sua voz e um violão. Provavelmente foi um registro com utilidade prática. Era preciso que o diretor musical e os atores aprendessem as canções. Edu Lobo (responsável pela orquestração) criou belíssimas linhas instrumentais que acompanhariam a peça em forma de playback, mas era necessário ensaiar o canto antes que esse material ficasse pronto. Essa hipótese é

Dori Caymmi, o diretor de produção Cacá Teixeira e o assistente de produção Renato Laforet, além de Herbert Richers Jr., ator que assistiu ao ensaio aberto em 1973. E para melhor compreender a montagem de Calabar de 1980, dirigida por Peixoto em uma conjuntura diferente, foram entrevistados o ator Sérgio Mamberti e o diretor musical Marcus Vinicius.

3 Calabar foi encenada novamente por Peixoto em 1980, com outro grupo de artistas. A encenação de 1980 tinha condições produtivas e propostas estéticas diferentes da encenação de 1973. . 
reforçada pelo fato de a fita ter sido encontrada no arquivo do encenador, e não do próprio compositor ${ }^{4}$.

Mas a presença dessa gravação entre as reflexões de Peixoto abre uma questão importante. Calabar reuniu uma equipe impressionante de artistas: Chico Buarque e Ruy Guerra na dramaturgia, Dori Caymmi na direção musical, Edu Lobo na orquestração, Mário Masetti e Zdenek Hampl como diretores assistentes, Zdenek Hampl na coreografia, Hélio Eichbauer na cenografia e figurinos (em parceria com Rosa Magalhães). Isso sem contar os grandes atores e músicos - basta conferir a ficha técnica $^{5}$ para constatar a excelência dos trabalhadores que criaram a peça. A contribuição de cada um desses artistas para a montagem também poderia ser objeto de estudo. Por que focar no trabalho da encenação?

A resposta a essa questão será desenvolvida ao longo dos capítulos, mas algo já pode ser dito sobre o assunto. Em primeiro lugar, já existem algumas análises a respeito da dramaturgia de Chico Buarque e Ruy Guerra ${ }^{6}$. As duas versões editadas do texto aquela publicada em 1973 e a versão revista para a montagem de 1980 - estão disponíveis para estudo nas bibliotecas. Já a análise de uma encenação teatral ocorrida em um tempo histórico passado parte sempre de um problema: a impossibilidade de assistir à peça, de passar pela experiência de ser um espectador. E isso se agrava quando se trata de uma montagem censurada, que não teve a chance de ser analisada pela crítica especializada. Apesar dessas dificuldades, a historiografia teatral não pode se restringir ao estudo de dramaturgias ${ }^{7}$.

O trabalho da encenação é responsável justamente por orientar e articular a criação de todos os artistas envolvidos, de forma a produzir um todo com sentido estético e ético. Na colaboração e no atrito com as propostas dos demais artistas é que Peixoto teceu Calabar. As entrevistas realizadas durante a pesquisa permitiram a inclusão de uma diversidade de olhares sobre o processo criativo conduzido pelo diretor.

4 Além dessas gravações, um lado de uma das fitas é uma leitura cênica da peça Um grito parado no ar, encenado por Peixoto no mesmo ano de 1973. E após o depoimento que Peixoto gravou sozinho há um trecho de outra leitura cênica. As fitas eram usadas em toda a sua capacidade de armazenamento, o que explica a sobreposição de materiais de diferentes processos teatrais.

${ }^{5}$ A ficha técnica está disponível como anexo da dissertação (Anexo A).

6 Por exemplo: Elizabete Santos Rocha realiza uma análise da dramaturgia de Calabar do ponto de vista literário (ROCHA, 2006), e Christian Alves Martins aborda o texto do ponto de vista histórico em seu mestrado (MARTINS, 2007) e em seu doutorado (MARTINS, 2013).

${ }^{7}$ Raymond Williams, crítico galês, desenvolveu uma metodologia para a análise de encenações ocorridas no passado. Seu livro Drama em cena (2010) é uma referência nesse sentido. 
Nas fitas em que reflete sobre a encenação, Peixoto menciona questões específicas sobre cada área do trabalho teatral - dramaturgia, atuação, música, cenografia, figurinos, iluminação etc. Suas observações não serão tratadas como neutras, mas como reveladoras de determinado projeto teatral em construção e em disputa.

Além das fitas, outros documentos importantes foram levantados no Arquivo Fernando Peixoto. São eles: os cadernos do encenador, a primeira versão e a segunda versão da dramaturgia com anotações de Fernando Peixoto, fotografias inéditas, notícias de jornal a respeito da encenação censurada, registros ligados aos testes de elenco, e documentos referentes à encenação de 1980, quando a dramaturgia de Calabar finalmente culminou em uma estreia.

A diversidade de documentos presentes no Arquivo revela como Peixoto era organizado: seu cuidado em deixar rastros está ligado ao seu papel importante na construção de um teatro brasileiro. Papel que exerceu como diretor e ator, mas também como crítico e intelectual. A disputa da memória e do lugar social do teatro em uma nação fazia parte de suas preocupações. Textos de Peixoto já publicados, produzidos em diversos momentos de sua carreira, foram mobilizados nas análises aqui realizadas. Diversos materiais inéditos encontrados no Arquivo foram mais bem compreendidos à luz de seus escritos já divulgados em livros.

Para analisar as reflexões de Peixoto sobre Calabar, é importante situar em que momento de sua trajetória artística ele se encontrava: com quais tradições teatrais dialogava, e com qual projeto de país. Não pretendemos dar conta de todos os aspectos de sua biografia. Serão pouco tratadas aqui as suas realizações ligadas ao jornalismo cultural e à crítica teatral, por exemplo. Serão estudados especialmente a pontos de sua trajetória que estão ligados à suas escolhas na montagem de Calabar, e que dizem respeito à sua formação como diretor teatral.

Estudos com Ruggero Jacobbi, experiência com o CPC e o projeto Nacional Popular

Fernando Peixoto se formou em interpretação no Curso de Arte Dramática da Faculdade de Filosofia da Universidade do Rio Grande do Sul. O diretor do curso era Ruggero Jaccobi, importante encenador italiano que participou do processo de modernização do teatro brasileiro, e influenciou diversos artistas em uma prática que 
articulava arte e política. No período em que esteve no Brasil, Jacobbi trabalhou no $\mathrm{TBC}^{8}$ (onde defendeu o crescimento do interesse por temas sociais), organizou com Guarnieri e Vianinha o Teatro Paulista do Estudante, e influenciou fortemente o Teatro de Arena na busca por uma dramaturgia e encenação dedicadas a colocar em cena os problemas do povo brasileiro.

Segundo Peixoto, Jacobbi já acreditava que ele seria um diretor, e ainda na escola incentivou-o a dirigir sua primeira peça (Matar, de Paulo Hecker Filho, em 1959). Também em Porto Alegre participou do grupo semiprofissional Teatro de Equipe, muito inspirado pelo Teatro de Arena de São Paulo. Segundo ele, havia a "tentativa de criar um teatro gaúcho que caminhasse para o profissionalismo" (PEIXOTO, 1989d, p. 136). Ali dirigiu Pedro Mico, de Antonio Callado, em 1961.

Muitos encenadores aproximam-se de sua atividade realizando assistência de direção para artistas mais experientes. Peixoto foi assistente de Jacobbi em diversos espetáculos, e a ele credita uma parte essencial de sua formação: “ele foi para mim a personalidade e o amigo mais decisivo e essencial de toda a minha formação artística e política. Foi quem me fez ler e estudar Hegel e Marx, Pirandello e Goldoni, Gonçalves Dias e Oswald de Andrade, Stanislavski e Brecht” (PEIXOTO, 1998, p. 38). Os autores mencionados (sempre em duplas significativas) dizem muito sobre o encenador que ele se tornou. Hegel deu a Peixoto uma base sobre o método dialético, e Marx contribuiu com o pressuposto materialista. Pirandello abriu caminho para o experimentalismo na dramaturgia, enquanto o interesse por Goldoni alude à valorização da cultura popular. Gonçalves Dias é um dos primeiros representantes da dramaturgia escrita por brasileiros, e Oswald de Andrade participou dos debates em torno da modernização do teatro brasileiro. Stanislavski propôs um método de atuação realista, e Brecht apontou esse realismo para os debates políticos e sociais, lançando mão do materialismo dialético. As duplas mencionadas reúnem autores que criaram bases consistentes para o pensamento ou para a arte, e autores ligados a preocupações políticas ou temas nacionais e populares.

\footnotetext{
${ }^{8}$ Teatro Brasileiro de Comédia, empreendimento organizado por Franco Zampari a partir de 1948 que é considerado um marco na modernização do teatro brasileiro. O TBC trouxe ao país diversos diretores europeus atentos às renovações na arte da encenação, e foi fundamental para a profissionalização dos artistas teatrais no Brasil. Foi uma modernização ligada à burguesia paulista, que inicialmente buscava encenar em São Paulo os clássicos consagrados da dramaturgia europeia. Aos poucos, textos e temas brasileiros entraram no repertório do TBC, e alguns diretores brasileiros puderam encenar montagens ali.
} 
Quando Jacobbi deixou o Brasil, em 1960, escreveu uma carta de despedida a Peixoto. Nessa carta ele sintetizou os princípios que defendeu durante sua estadia no país, e que muito contribuíram para a formação de Peixoto como diretor. Os princípios são os seguintes: a "afirmação do realismo contra os delírios místicos, criação de uma dramaturgia brasileira como matéria-prima indispensável do teatro, fundação de uma cultura nacional popular” (PEIXOTO, 1998, p. 38 grifo nosso). Veremos como os “delírios místicos” estavam em voga naquela época, ligados a uma atitude artística experimental que foi se afastando do interesse pela realidade social. Por outro lado, uma realidade social que massacrava tentativas de transformação tendia a incentivar esse afastamento.

O projeto de construção de uma dramaturgia brasileira foi inspirador de toda uma geração. Um polo disparador importante desse projeto (que contou com a participação de Jacobbi) foi o Seminário de Dramaturgia ${ }^{9}$ realizado no Teatro de Arena entre 1958 e 1961. Chico Buarque e Ruy Guerra, autores de Calabar, foram próximos do Arena e deram continuidade a esse objetivo comum. Como diretor, Peixoto optou com frequência por encenar textos de dramaturgos brasileiros, integrando-se a esse projeto.

A ideia do nacional popular merece atenção especial. Mário Masetti comentou em entrevista que essa era “a essência da tese do Fernando"10. O conceito foi desenvolvido na Itália por Antonio Gramsci, e Jacobbi foi um dos responsáveis por adaptá-lo aos debates sobre a arte e a cultura no Brasil da época ${ }^{11}$. No Brasil dos anos 1950 a 1970, a ideia de nacional e popular foi cultivada por artistas e intelectuais de esquerda, e objetivava "refletir sobre o país sob o prisma do proletariado e da crítica aos processos de exploração do trabalho” (GUINSBURG; FARIA; LIMA, 2009, p. 211). Muitos artistas e intelectuais de esquerda eram ligados então ao Partido Comunista Brasileiro (PCB), inclusive Fernando Peixoto. Após a divulgação dos crimes cometidos

\footnotetext{
${ }^{9}$ Segundo Paula Autran: "Ainda que seja difícil medir o grau da influência de Ruggero Jacobbi, não há dúvida que foi uma das presenças críticas mais importantes na politização do trabalho do Arena" (AUTRAN, 2015, p. 20). A preocupação com a construção de uma dramaturgia brasileira está ligada a essa politização. Paula Autran realizou um estudo especificamente sobre os Seminários de Dramaturgia, que foi publicado. AUTRAN, Paula. Teoria e Prática do Seminário de Dramaturgia do Teatro de Arena. São Paulo: Portal, 2015.

10 MASETTI, Mário. Entrevista sobre Calabar. Entrevistadora: Nina Hotimsky. São Paulo, nov. 2016. 11 Apenas na segunda metade da década de 1970 os textos de Gramsci foram traduzidos para o português, e ganhou espaço no ambiente acadêmico um debate sobre o sentido original do conceito Segundo o Dicionário do Teatro Brasileiro, "Na Itália, nacional popular surgira como forma de revolução "passiva" capaz de articular povo e setores intelectuais contra cultura dominante" (GUINSBURG; FARIA; LIMA, 2009, p. 214).
} 
por Stalin, em congresso de 1956, o PCB abriu mão do realismo socialista como diretriz para a criação artística, e em certa medida incentivou que outras formas de expressão fossem experimentadas.

Em Congresso de 1958, o PCB “define o caráter de revolução no Brasil como essencialmente nacional e democrático” (GUINSBURG; FARIA; LIMA, 2009, p. 211). Ao priorizar a luta anti-imperialista, o Partido abriu espaço, no campo cultural, para um debate a respeito da cultura brasileira. A ideia de nacionalidade estava então em disputa. Veremos que essa disputa também se expressa na dramaturgia de Calabar.

O interesse por temas e formas brasileiros foi abraçado pelo Teatro Paulista do Estudante, com colaboração de Ruggero Jacobbi ${ }^{12}$; pelo Teatro de Arena (sobre o qual falaremos em breve); e ainda antes do golpe civil-militar, pelos Centros Populares de Cultura da União Nacional dos Estudantes (CPCs da UNE) ${ }^{13}$. As forças reacionárias que chegaram ao poder em 1964 também disputavam a ideia de nação brasileira. Basta lembrar o slogan "Brasil: ame-o ou deixe-o”, que circulava em adesivos de carros no início da década de 1970, durante o governo do general Emílio Médici ${ }^{14}$. A arte de esquerda buscava uma cultura popular revolucionária, e a direita afirmava proteger o país do comunismo, através da valorização da família, da religião, das tradições, da propriedade.

12 Sara Mello Neiva realizou uma pesquisa de mestrado especificamente em torno do Teatro Paulista do Estudante e as origens do nacional popular no Brasil.

13 Segue uma rápida contextualização sobre o CPC: "O Centro Popular de Cultura - CPC é criado em 1961, no Rio de Janeiro, ligado à União Nacional de Estudantes - UNE, e reúne artistas de distintas procedências: teatro, música, cinema, literatura, artes plásticas etc. O eixo do projeto do CPC se define pela tentativa de construção de uma "cultura nacional, popular e democrática", por meio da conscientização das classes populares. A idéia norteadora do projeto diz respeito à noção de "arte popular revolucionária", concebida como instrumento privilegiado da revolução social. A defesa do caráter coletivo e didático da obra de arte, e do papel engajado e militante do artista, impulsiona uma série de iniciativas: a encenação de peças de teatro em portas de fábricas, favelas e sindicatos; a publicação de cadernos de poesia vendidos a preços populares; a realização pioneira de filmes auto-financiados”. CENTRO Popular de Cultura (CPC). In: ENCICLOPÉDIA Itaú Cultural de Arte e Cultura Brasileiras. São Paulo: Itaú $\quad$ Cultural, $2019 . \quad$ Disponível em: <http://enciclopedia.itaucultural.org.br/grupo399389/centro-popular-de-cultura-cpc>. Acesso em: 26 de Jun. 2019. Verbete da Enciclopédia. ISBN: 978-85-7979-060-7

14 Chico Buarque mencionou esse slogan ao descrever a conjuntura brasileira no início da década de 1970, quando ele retornava de seu autoexílio na Itália: "Eu vim realmente começar a entender o que estava acontecendo quando cheguei de volta, em 1970. Era uma barra muito pesada, vésperas de copa do mundo. Foi um susto chegar aqui e encontrar uma realidade que eu não imaginava. Em um ano e meio de distância dava pra notar. Aqueles carros entulhados com os "Brasil, ame-o ou deixe-o", ou ainda o "Ameo ou morra" nos vidros de trás. Mas não tinha outra. Eu sabia que era o novo quadro, independentemente de choques ou não. "Muito bem, é aqui que eu vou viver." Que realmente eu já estava aqui de volta. Então fiz o Apesar de você" (BUARQUE, 1979).

Em 2018, o canal de televisão SBT voltou a veicular o slogan "Brasil: ame-o ou deixe-o". A eleição de Jair Bolsonaro como presidente representou em certa medida a retomada de um projeto de Brasil defendido pelo regime civil-militar. 
A experiência dos CPCs ocorreu de 1961 a 1964. Ela reuniu artistas e intelectuais de esquerda em diversos estados brasileiros dispostos a realizar uma "tarefa de agitação e propaganda deliberadamente circunstancial”, como descreveu Peixoto (1989, p. 9), que integrou o núcleo gaúcho do CPC em 1962. Mas não havia um modelo engessado que ensinasse a realizar essa arte a serviço da Revolução. Ainda segundo Peixoto, os CPCs eram espaços de crítica e autocrítica constantes, e seu interesse pelo Brasil levou a pesquisas estéticas variadas em cada uma das linguagens artísticas. Por exemplo, no campo teatral, investigações em torno de aspectos da revista e da comédia popular.

O CPC foi palco de muitos debates em torno da ideia de nacional popular. Para Carlos Estevam Martins, interessava o que ele chamava de “popular revolucionário”. Considerava que a pauta principal não era a origem social do artista ou a forma do trabalho, e sim a posição de classe expressa pela obra. Ferreira Gullar discordava. Para ele,

o popular desejado passava pela incorporação de formas, como o cordel, o repente, a incelença e etc., ao trabalho dramatúrgico e artístico realizado: as formas nascidas ou inspiradas nos contextos de classe associados ao povo eram, a seu ver, fundamentais para o amadurecimento estético da expressão e para a coerência política do trabalho" (GUINSBURG; FARIA; LIMA, 2009, p. 211).

Peixoto participou ativamente desse debate. Ele relatou que um acontecimento chave para a sua tomada de decisão a esse respeito se deu quando, ao apresentar um espetáculo do CPC no Largo do Machado, os atores não conseguiram chamar a atenção do público. Todos os passantes estavam mais interessados em um sanfoneiro e um pandeirista que tocavam ali ao lado. Houve um debate acalorado, e Peixoto gritava que preferia sair com os sanfoneiros: “'Vocês pretendem se comunicar com a massa e estão levando uma linguagem que não está passando’. Foi daí que surgiu esta concepção do CPC de que deveríamos usar as formas populares e rechear estas formas com o melhor conteúdo ideológico possível” (1989a, p. 17).

Anos depois, em 1989, Peixoto organizou uma coletânea de dramaturgias produzidas pelos CPCs. Produziu à guisa de introdução um texto em que descreve os debates e realizações dos Centros Populares de Cultura (de onde foram extraídos parte dos depoimentos que constam nesse trabalho), e os inscreve em um contexto histórico bastante específico: 
Impossível pensar CPC fora dos nem sempre nítidos contornos que assumia, no Brasil de 1961 a 1964, o projeto de reformas de base e de desenvolvimentismo nacional frente a um reordenamento monopolista do capitalismo internacional e especialmente em face de uma agressiva redefinição do imperialismo norte-americano em relação à América Latina após o triunfo da Revolução Cubana (PEIXOTO, 1989a, p. 10).

Como intelectual, fez questão de revisitar as obras e debates produzidos nos CPCs. Avaliou que artistas de esquerda das novas gerações teriam de lidar com outros contextos históricos, e inventar novas formas e estratégias. Ao mesmo tempo, defendeu a importância de conhecer as experiências anteriores de teatro político para lidar com essa tarefa.

Em textos de diversos momentos de sua carreira, Peixoto frequentemente descreveu seu projeto teatral a partir da formulação de Ruggero Jacobbi: a luta por um $\underline{\text { teatro nacional popular, realista e crítico }}^{15}$. Em entrevista de 1980, ludicamente separou as palavras “nacional” e “popular”, pois percebeu equívocos na interpretação do conceito: "Talvez fosse melhor eu dizer nacional, crítico, realista e popular... não aproximar [nacional e popular] para não haver mal-entendido. Mas eu acho que as quatro juntas formam um todo” (1989b, p. 73). A ideia de nacional popular foi um terreno de disputa no campo acadêmico recente, e foi relacionada com diferentes avaliações sobre o teatro brasileiro dos anos 1960. Mas artisticamente essas quatro palavras nortearam o trabalho de Peixoto como encenador: "É um confronto crítico com a realidade feito a partir de instrumentos e de uma consciência nacional, a partir de uma perspectiva popular. Essa coisa toda misturada acho que dá uma definição do que eu gostaria que fosse o que fiz” (1989b, p. 71). Esse depoimento é de 1980, e em muito reflete as preocupações do diretor ao ensaiar o Calabar de 1973.

\section{Teatro Oficina: Stanislávski, Brecht, o coro de Zé Celso, a contracultura}

O desejo de trabalhar com teatro profissionalmente acabou levando Peixoto a mudar-se para São Paulo, em 1963. Anos depois, em texto de 1989 sobre a "Diáspora teatral interna”, ele afirmou ter sido forçado a emigrar: “Artistas e técnicos vêm de todo o país, pressionados pela mesma falta de perspectivas em assumir nosso trabalho como

${ }^{15}$ Grifo nosso. Ele credita a Jacobbi essa formulação em seu texto “Até sempre, Ruggero”. (PEIXOTO, 1989b, p. 242). 
profissão viável fora dos centros economicamente privilegiados”. (PEIXOTO, 2002, p. 35). Nesse artigo, Peixoto admite que teria sido possível permanecer em Porto Alegre exercendo a carreira de jornalista e fazendo teatro amador, mas que em seu caso essa opção teria sido feita "não por justa e livre escolha mas sim como condenação" (PEIXOTO, 2002, p. 34). Embora como intelectual defendesse o teatro amador como prática social relevante (atribuindo-lhe tarefas como o incentivo à formação de uma dramaturgia nacional e a apresentação de espetáculos para as classes menos favorecidas economicamente ${ }^{16}$ ), e embora tenha colocado o teatro a serviço da militância política na experiência com o CPC, a sua escolha de vida foi pela profissionalização. Veremos mais adiante como essa opção faz parte da crise de Peixoto por ocasião da encenação de Calabar.

Chegando a São Paulo o artista integrou-se ao elenco e à direção do Teatro Oficina, onde permaneceu até 1970. Em texto publicado poucos anos depois de seu rompimento com o grupo, Peixoto afirmou que “de 1963 a 1970, José Celso Martinez Corrêa foi certamente o encenador mais importante do país”. (PEIXOTO, 2002, p. 185). Mesmo após separar-se do projeto estético e político do grupo, seguiu valorizando o trabalho teatral vivido ali.

Ao escrever sobre a história do Teatro Oficina, Peixoto nomeia o período de 1962 a 1966 como o “ciclo russo-soviético” (PEIXOTO, 2002, p. 202). Ele considera como participantes desse ciclo os espetáculos Quatro Num Quarto (de Valentin Kataev, primeiro espetáculo do grupo em que Peixoto participa como ator, substituindo Ronald Daniel), Pequenos Burgueses (em que atua) e Os Inimigos (onde realiza a assistência de direção, trabalha na adaptação dramatúrgica e na iluminação). Ele também trabalhou, em parceria com Zé Celso, na tradução dos dois últimos textos (escritos por Máximo Gorki).

O ciclo russo-soviético compreendia mais do que a montagem de dramaturgias russas. Este foi o período em que o grupo realizou um esforço conjunto para verticalizar dois campos de pesquisa. Por um lado, experimentava-se o método de trabalho de

16 Essas duas propostas foram formuladas em 1960, no texto "Desorientação e irresponsabilidade". (PEIXOTO, 2002, p. 25). O vislumbre do amadorismo como lugar para a pesquisa de linguagem e a ousadia política também está presente em "Um desafio para o teatro não profissional”, de 1985 (PEIXOTO, 2002, p. 213). Outro momento interessante em que ele menciona o teatro amador é na entrevista "Teatro brasileiro - um desafio em aberto", de 1987. Ali descreve o amadorismo como um "movimento imenso, rico e contraditório. E está inteiramente organizado: cada estado tem a sua federação de grupos amadores e existe uma poderosa Confederação Nacional do Teatro Amador" (PEIXOTO, 1989d, p. 150). 
Konstantin Stanislávski, sob orientação do ator russo Eugênio Kusnet: “Com Kusnet e contra Kusnet travávamos nossa batalha de questionamento do processo stanislavskiano, e dela aprendemos a vivenciar e manipular as lições do mestre russo. $\mathrm{O}$ próprio Kusnet passava por um instante de viva indagação”. (PEIXOTO, 2002, p. 204). O grupo mergulhava na interpretação realista-psicológica e no método das ações físicas.

Por outro lado, e especialmente após o golpe de 1964, crescia o interesse pelo teatro épico dialético de Bertolt Brecht. O Teatro Oficina desde a sua origem estava preocupado em colocar em pauta a realidade social brasileira, e as dramaturgias de Brecht, assim como seus trabalhos como encenador, vieram fortalecer esse viés do trabalho. O estudo de Brecht se desenvolvia à medida que o grupo se politizava, processo que Peixoto atribui à conjuntura brasileira de estado de exceção, à pesquisa sobre a Revolução Soviética (realizada em torno das montagens de Górki) e à presença de militantes do Partido Comunista dentro do grupo (sendo Peixoto um desses militantes).

Zé Celso, Renato Borghi e Fernando Peixoto, membros do Teatro Oficina, revezaram-se em algumas viagens de pesquisa à Europa, e especialmente à República Democrática Alemã. Ali visitavam o Berliner Ensemble, grupo em que Brecht realizou suas propostas de encenação e que após a sua morte seguiu ativo artisticamente. Voltavam com as malas cheias de dramaturgias, fotografias e programas de espetáculos, além de discos com as canções de cena compostas por Kurt Weill, Hanns Eisler e Paul Dessau. Estudavam os materiais coletivamente, através de debates e de experimentações práticas. A existência de um núcleo estável de artistas pesquisadores e de um teatro onde ficar em cartaz (além, é claro, dos recursos para realizar as viagens de investigação) facilitava o aprofundamento dos estudos e seu desdobramento concreto no trabalho artístico do Teatro Oficina.

Foi em uma dessas visitas de Peixoto ao Berliner Ensemble que ele entrou em contato como espectador com o trabalho do encenador Manfred Wekhwerth. Wekhwerth foi assistente de Brecht desde 1951, e mais tarde dirigiu seus próprios espetáculos no Berliner. Peixoto descreve a experiência: “me marcaram pela espantosa inventividade da linguagem cênica, produtos acabados de toda a teoria brechtiana que eu havia estudado sem imaginar o alcance poético e político que poderiam resultar no palco”. (PEIXOTO in WEKWERTH, 1986, p.11). 
Especialmente na montagem de Os Inimigos, em 1966, houve a influência do encenador francês Roger Planchon (também estudioso de Brecht), outra fonte de inspiração advinda das viagens à Europa. Segundo Peixoto, os ensinamentos brechtianos neste espetáculo eram expressos através do que ele chamou de um "historicismo” na encenação: “O espetáculo é precedido de uma montagem de dispositivos (imagens, frases, estatísticas) que introduzem o espectador na cronologia, na compreensão dos acontecimentos” (PEIXOTO, 2002, 212). Esse "historicismo” também se fará presente, mais tarde, na encenação de Calabar ${ }^{17}$.

Um outro dado de Os Inimigos que precisa ser mencionado é a criação musical: "Chico Buarque de Hollanda escreveu uma trilha sonora inspirada em canções e hinos soviéticos” (PEIXOTO, 2002, 212). Este foi um momento em que Chico Buarque e Peixoto produziram juntos, antes de Calabar. O compositor, que no ano anterior musicara os poemas de João Cabral de Melo Neto para a encenação de Morte e Vida Severina $^{18}$ (seu primeiro trabalho com teatro), seguia experimentando o papel da canção em uma arte teatral politizada.

Chico Buarque afirma ter aprendido muito sobre a relação entre teatro e música ao compor para Morte e Vida Severina. Em depoimento de 1980 o artista descreveu:

Eu tinha a sensação de ser o caçula daquele pessoal, sentia uma incapacidade, achando que não ia conseguir musicar o poema. Em todo caso, discutia tudo, falava de tudo, e eu não entendia nada, nem de teatro. Foi com receio e aos poucos que eu fui aceitando participar e me acostumando com a ideia de fazer as músicas. (...) Nunca mais me separei do teatro. Não é que eu esteja me desviando para o teatro: desde o meu começo eu estava muito próximo dele. Eu também trabalho com o texto: às vezes eu quero dizer uma coisa que não cabe numa canção. Assim, era normal que eu partisse para o texto de teatro (BUARQUE, 1980).

O texto de João Cabral de Melo Neto foi escrito inicialmente não para ser cantado, e sim declamado. Chico Buarque enfrentou a dificuldade de musicar um texto “seco”, com alguns versos “imusicáveis” (BUARQUE, 1980). Conforme observou o pesquisador Walter Garcia, há em Morte e Vida Severina uma irregularidade nos versos

\footnotetext{
${ }^{17}$ Peixoto utiliza o adjetivo "historicista" ao escrever sobre o Calabar de 1973, em comparação com o Calabar de 1980. Essa comparação é feita no contexto de um artigo sobre o cenógrafo Helio Eichbauer, que trabalhou em ambas as montagens: “(...) seria oportuno, mas exaustivo, um exame detalhado das duas versões de Calabar: a primeira fundamentada numa postura historicista e narrativa, a descrição crítica de um instante histórico, a segunda, ao contrário, o estabelecimento de um espaço teatral seco e despojado, cru e num armado com uma textura tosca e corajosamente bruta” (PEIXOTO, 1989d, p. 127).

18 Espetáculo que estreia no Teatro da Universidade Católica em 1965, com direção de Silnei Siqueira.
} 
que "parece dar privilégio aos "processos de pensar por meio de palavras"19, dificultando, ao menos em parte, o predomínio do embalo que, via de regra, dispensa o entendimento intelectual” (GARCIA, 2011, p. 163). A variação do número de sílabas poéticas pode ter o efeito de manter o ouvinte atento aos temas e debates veiculados, e não apenas imerso em sua sonoridade. Chico soube respeitar o texto: “o grande acerto na “extração” da musicalidade do poema decorre da economia de recursos. A linguagem musical, retraindo-se, não prejudica o entendimento da letra” (GARCIA, 2011, p. 165).

É provável que essa experiência tenha contribuído para o trabalho seguinte de Chico Buarque com o Teatro Oficina, que à época estudava as propostas de Bertolt Brecht; e também para a composição das canções de Calabar. A irregularidade dos versos em uma canção de cena possui parentescos com o efeito de estranhamento ${ }^{20}$ buscado pelo teatro dialético; ela pode ajudar a manter o espectador atento sobre o sentido do que é cantado. Há nisso uma semelhança com outras estratégias teatrais buscadas por Brecht (não apenas no campo da música de cena, mas também na atuação, cenografia, figurinos, iluminação) para evitar a “identificação por abandono” do espectador com o fluxo dramático e os conflitos privados das personagens. As interrupções no fluxo dramático ou musical no contexto de um teatro épico teriam como objetivo chamar a atenção para aspectos políticos, históricos e sociais de determinada situação. Para Brecht, o teatro "tem de fazer que o público fique assombrado, o que conseguirá, se utilizar uma técnica que o distancie de tudo o que é familiar. Esta técnica permite ao teatro empregar (...) o método da nova ciência social, a dialética materialista” (BRECHT, 2005, p. 146). A sensação de familiaridade está associada à impressão de que determinada situação social é inalterável. Contra essa sensação, buscava-se representar um mundo transformável. Claro que nem toda canção com versos irregulares possui esse objetivo, mas as canções de Chico Buarque compostas para um teatro politizado podem ser estudadas sob esse viés.

Tanto em Os Inimigos como em Morte e Vida Severina, a trilha foi resultado de uma pesquisa com gêneros musicais específicos - os hinos soviéticos e as canções nordestinas tradicionais. Nos dois casos, situar a ação em outro espaço geográfico e em

19 Garcia credita essa formulação a Mário de Andrade: “Aproveito observação de Mário de Andrade sobre o ritmo na poesia (cf. Mário de Andrade, “Os compositores e a língua nacional”, in . Aspectos da música brasileira, Belo Horizonte/Rio de Janeiro, Villa Rica, 1991, p. 32)”.

20 Dependendo da tradução para a língua portuguesa, o efeito de estranhamento proposto por Bertolt Brecht também é denominado “distanciamento”. 
outra época dava amparo à crítica social do aqui-e-agora, e ajudava a evitar problemas com a censura. Esse mecanismo também foi utilizado, anos mais tarde, em Calabar.

O ciclo russo-soviético do Teatro Oficina foi encerrado em 1966. Um marco da mudança foi o incêndio que vitimou parte do teatro, e obrigou o grupo a repensar toda a sua prática. No ano seguinte, Fernando Peixoto participou como ator da histórica montagem de $O$ Rei da Vela (dramaturgia de Oswald de Andrade e direção de Zé Celso Martinez Corrêa). Considerou-a um marco pela "proposta do antropofagismo cultural (em seguida consumido pela cultura de consumo e pela burguesia como simples “tropicalismo”, esvaziado de seu conteúdo revolucionário e destruidor)” (PEIXOTO, 2002, p. 185). Paulo Bio, em sua tese de doutorado, mostra como a encenação de $O$ Rei da Vela - e os textos de Zé Celso e de Peixoto publicados no programa da peça revelava diferentes visões artísticas e políticas dentro do Teatro Oficina. Enquanto Zé Celso, ao longo de sua trajetória, apoiou a identificação do espetáculo com o tropicalismo ${ }^{21}$, Fernando Peixoto privilegiava os aspectos materialistas da obra, a sua crítica ao capitalismo.

O ano de 1968 é central nessa constituição de diferentes narrativas sobre a história do Teatro Oficina. Zé Celso realizou uma montagem fora do grupo, mas fundamental para a sua formação como encenador: Roda Viva, primeira peça escrita por Chico Buarque (sua dramaturgia seguinte foi justamente Calabar). É verdade que em 1973 Chico afirmou: “Há uma diferença de seis anos de Roda Viva para Calabar. Para mim, nessa faixa de 20 a quase 30 anos, a gente muda muito. Calabar é um trabalho bem mais elaborado" (BUARQUE; GUERRA, 1973, p. 2). Também é preciso considerar que Calabar foi escrita em parceria com Ruy Guerra. No entanto, há uma semelhança importante entre essas duas dramaturgias: a indicação de um coro ou figuração presente nas rubricas. Ambos os textos incluem cenas nas quais os protagonistas não se bastavam.

No caso de Roda Viva, rubricas indicavam "bonecos” que aplaudissem e vaiassem o ídolo; vozes em off "rezando o credo”; figurantes que cumprissem diversos papéis, como o de "bailarinas e bichas dançando um balé desconjuntado à maneira habitual na TV”, “artistas, em um empurra-empurra habitual”, e “meninas pedindo autógrafos” (BUARQUE, 1967, p. 15-24). Em alguns momentos a dramaturgia se

21 É importante lembrar que o tropicalismo não foi um movimento planejado, tanto que muitos artistas identificados com a corrente preferem chama-la "Tropicália", retirando o sufixo "ismo" relacionado à noção de movimento organizado. 
refere ao coro como "Povo”, o que se repetirá em Calabar. Veremos como a inclusão desse "Povo” em Calabar gerou consequências estéticas e políticas.

O gesto fundamental de Zé Celso ao encenar Roda Viva foi radicalizar essa presença coral e orientá-la para determinada direção. Ao invés de contratar os quatro atores previstos para a dita figuração, e aceitar os recursos dos bonecos e das vozes em off para dar a impressão de um maior número de pessoas em cena (como sugeriam as rubricas), Zé Celso convocou todos os treze jovens que foram fazer o teste. Formou-se um coro que rompia a relação tradicional de separação entre palco e plateia, e chegava a interagir corporalmente com os espectadores. Segundo o encenador, o coro passou a ser a estrela: “Os jovens de 68 pediam a imaginação no poder. E naquele coro emergiu uma força humana que dançava, cantava, que tocava nas pessoas, sem barreiras. (...) quem criou a peça foi aquela geração”. (CORRÊA, 2012, p. 6). O papel do coro em Roda Viva estava ligado aos horizontes de politização nutridos por Zé Celso, reflexo de uma geração e de determinada conjuntura internacional e nacional.

Peixoto e Zé Celso estiveram na França em maio de 1968 (aproximadamente quatro meses após a estreia de Roda Viva), e presenciaram a demanda pela "imaginação no poder”. Zé Celso afirma que “Roda Viva só podia ter acontecido em 1968, momento em que o mundo inteiro foi abalado” (2012, p. 5). Nos atos e nas reinvindicações do maio de 1968 francês se experimentava uma outra forma de fazer política, que incluía as dimensões lúdica, estética, e até erótica: “Necessidades instintuais e razão se reconciliam, eliminando a punição da sensualidade ou da reflexão. Princípio de vida, eros, felicidade sensual e instintiva: 68 foi uma luta para a vida”. (MATOS, 1981, p. 15). Uma das características fundamentais daquele movimento foi a união (ainda que pouco duradoura) entre manifestações estudantis e greves de trabalhadores; ocupação de universidades pelos estudantes e ocupação e de fábricas pelos operários.

Enquanto isso, no Brasil, o ano de 1968 foi marcado pelo Ato Institucional Número Cinco, o AI-5 (em 13 de dezembro, meses após a estreia de Roda Viva). Intelectuais, artistas e estudantes se encontravam apartados do povo e de movimentos sociais de base (que já haviam sido duramente reprimidos desde o golpe de 1964), o que fomentou o desenvolvimento de uma forma específica de contracultura. Os jovens que questionavam a sociedade, mas que não mais viam perspectivas de mudanças 
estruturais, por vezes encontravam no desbunde ${ }^{22}$ uma maneira de manifestar sua insatisfação.

É importante lembrar que essa não foi a única vertente de politização dos jovens $^{23}$ brasileiros após o AI-5. Apesar do contexto repressivo, diversos coletivos se mantiveram mobilizados em torno de diferentes leituras de conjuntura e formas de organização $^{24}$. O PCB seguia com suas atividades; o movimento estudantil era composto por diversos grupos. Setores da Igreja Católica ligados à Teologia da Libertação protagonizaram uma resistência importante ao Regime Civil-Militar. Houve também as iniciativas de luta armada, que se intensificaram a partir de 1969 e foram progressivamente massacradas até 1974. A guerrilha é, aliás, um dos temas tocados pelo espetáculo censurado Calabar.

Fernando Peixoto não participou da montagem de Roda Viva. Segundo ele, aquele espetáculo não teria sido, naquele momento, produzido dentro do Oficina (PEIXOTO, 1982, p. 67). Naquele mesmo ano, e já após presenciar o maio de 1968 francês, ele realizou sua primeira direção dentro do grupo: a peça Poder Negro, escrita pelo norte-americano Leroy Jones. O texto tratava das lutas raciais travadas nos Estados Unidos, “fazia parte do radicalismo político de 68” (PEIXOTO, 1989b, 66). Ao contrário de Roda Viva, que estreou antes de maio, a encenação de Poder Negro foi diretamente influenciada pelo movimento francês: "Eu vinha com uma carga imensa de desejo de discussão cênica dos enunciados de Marcuse, a revolução será feita pelos marginais”. (PEIXOTO, 1989b, p. 156).

Herbert Marcuse foi um dos intelectuais que inspiraram os estudantes franceses em suas ações políticas, ao articular as ideias de Freud e de Marx. Poder Negro é uma peça sobre conflitos raciais, mas Fernando Peixoto abordava a questão negra em relação com a luta de classes. Determinadas leituras de Marx não consideram os membros do chamado lumpen proletariado como sujeitos potencialmente revolucionários. A população situada socialmente abaixo do proletariado, não organizada em espaços de trabalho, não teria sua consciência de classe desenvolvida e não teria meios de articularse politicamente. Marcuse, ao contrário, enxerga naqueles mais atingidos pela miséria e pela exclusão social uma potência de ação revolucionária. Nas palavras de Maciel, um

\footnotetext{
22 "Desbunde" foi um dos termos utilizados para designar as práticas contraculturais no Brasil. 23 Segundo Marcelo Ridenti (2007), os guerrilheiros eram majoritariamente jovens de camadas médias intelectualizadas, e de sexo masculino.

${ }^{24}$ Pode-se encontrar mais informações sobre as formas de luta social após o AI-5 no livro: FERREIRA, Jorge; REIS, Daniel Aarão. Revolução e democracia - 1964... São Paulo: Civilização Brasileira, 2007.
} 
dos intelectuais a divulgar as ideias de Marcuse no Brasil, em artigo sobre o autor: “A probabilidade é que, nesse período, os extremos históricos possam novamente se encontrar: a mais avançada consciência da humanidade e sua força mais explorada”. (MACIEL, 1973, p. 110).

Vê-se que a experiência do maio de 1968 alimentou Fernando Peixoto e Zé Celso de maneiras diferentes. Zé Celso aproximou-se das propostas da contracultura, e da contestação social através de uma mudança radical nos costumes. Fernando Peixoto seguiu pensando em termos de luta de classes e revolução social, incorporando as ideias de Marcuse e o interesse pela questão racial como parte de uma necessária mudança estrutural da sociedade.

Esse conflito ficou ainda mais claro na encenação seguinte do Teatro Oficina, Galileu Galilei (Bertolt Brecht), dirigida por Zé Celso ainda em 1968. O coro de Roda Viva foi incorporado ao espetáculo pelo encenador, especialmente na famosa cena do carnaval, em que o conhecimento chegaria ao povo. Começou a ser fomentada uma luta interna no grupo, entre os "representativos” (os atores mais antigos do Teatro Oficina, inclusive Peixoto, que representavam os papéis presentes na dramaturgia) e o coro (que alongava cada vez mais a cena do carnaval, e criava um envolvimento corporal com os espectadores, um teatro de ritual e festa). O diretor de Galileu Galilei dava continuidade à pesquisa iniciada em Roda Viva: experimentava a presença de um coro contracultural em cena.

É preciso reforçar que Zé Celso fomentava essa forma específica de atuação coral. A dramaturgia de Brecht lança mão de coros em diversas ocasiões ${ }^{25}$, com o objetivo de colocar em cena conflitos de ordem pública. O próprio termo “coro” surgiu na Grécia Antiga, quando um conjunto de atores tomava a palavra coletivamente; era um recurso importante das Tragédias Gregas, que debatiam por meio do teatro problemas comuns a todos os cidadãos. Mas nessa montagem de Galileu o coro não narrava problemas coletivos dos cidadãos, não representava uma população, e sim agia para produzir uma experiência sensorial e mágica de envolvimento com a plateia. Concepções importantes entravam em choque: racionalismo e irracionalismo;

25 As peças de aprendizagem escritas entre 1928 e 1930 (Aquele que diz sim e Aquele que diz não, A peça didática de Baden-Baden sobre o acordo, $O$ voo sobre o oceano, A exceção e a regra, A decisão) são muito marcadas por coros. Várias de suas peças de espetáculo também trabalham com esse recurso - a própria cena do carnaval em Galileu Galilei, e os coros de Santa Joana dos Matadouros, para citar alguns exemplos. 
materialismo dialético e contracultura; teatro como profissão ou teatro como experiência de rebeldia, voluntariamente marginal ${ }^{26}$.

É dessa crise que nasce a peça seguinte, última em que Peixoto participará como ator no Oficina: Na Selva das Cidades, de 1969. Segundo ele, durante os ensaios são elaboradas as “sérias mas estimulantes divergências internas” (PEIXOTO, 2002, 197). O texto é um dos primeiros de Bertolt Brecht, há nele uma violência que é aprofundada pela encenação. O teatro é fisicamente destruído durante a peça - pedaços de cenário, figurinos, objetos de cena. Em seus escritos sobre a peça, Peixoto elogia a encenação como “a direção mais sensível de José Celso, um trabalho que nasce da crise interna, aprofunda a crise interna e dela retira seu vigor e suas raízes. Tudo está em jogo dentro do grupo. A própria noção de companhia profissional” (PEIXOTO, 2002, p. 198). O histórico do grupo era sólido o suficiente para tirar consequências estéticas pertinentes de suas próprias diferenças.

Mas crescia para Peixoto a necessidade de separação. As apostas de Zé Celso naquele momento - irracionalismo, misticismo, revolução “dentro de si mesmo”, interesse crescente pelo afastamento do circuito profissional do teatro ${ }^{27}$ - eram muito diferentes das suas próprias convicções. Entre 1969 e 1970, Peixoto excursiona com o Teatro de Arena (experiência sobre a qual falaremos em seguida). Ao voltar, realiza um último trabalho com o Teatro Oficina: a direção da peça Don Juan, de Molière.

Era um espetáculo onde eu rompia com a estrutura do Oficina e ao mesmo tempo pagava a minha dívida com o Oficina. O espetáculo tinha todas as influências possíveis e impossíveis do Zé Celso. Eu inventei um coro que ficava andando pela plateia, simulando puxar fumo, era um delírio total. Havia no

\footnotetext{
${ }^{26}$ Ao expor os debates que circulavam no Teatro Oficina em 1969, Peixoto relata: "Para muitos o Oficina teria que voltar às suas origens, libertando-se do mercado empresarial e talvez mergulhando decididamente na contracultura” (PEIXOTO, 2002, p. 198). Esse questionamento ganhou cada vez mais espaço no grupo: ainda segundo Peixoto, a partir da montagem de Gracias Señor (1972) o Oficina fez a opção por uma "marginalização voluntária” (PEIXOTO, 1989b, p. 144).

${ }^{27}$ Peixoto escreveu muito sobre o Teatro Oficina, sempre com grande respeito pela importância do grupo. Em seu trabalho como intelectual do teatro, chegou a escrever um livro dedicado unicamente ao assunto: Teatro Oficina (1958-1982): Trajetória de uma Rebeldia Cultural. Peixoto explicou as razões pessoais de seu rompimento com o Oficina em alguns artigos e entrevistas. Nesse excerto ficam claras as suas divergências: "Não conseguia mais suportar as posições e os encaminhamentos do Zé Celso no teatro. Eram experiências irracionais na base do corporal, não se faz a revolução político-social, então tenta-se fazer dentro de si mesmo. Estavam num processo anárquico, de religiões orientais, com pessoas jovens e porraloucas. A barra estava meio pesada. Gostava do Zé Celso, do trabalho dele, apesar de tudo, mas não concordava com o trabalho, com as coisas que estavam fazendo... Não era isso o que queria fazer. Se continuasse indo, teria que agüentar um milhão de coisas, que já não dava mais ou ficar lá reclamando delas e brigando o tempo todo. Era melhor não ficar mais junto. É como um casamento. Não é que não goste da pessoa, mas não dá mais para ficar junto! Não era nada contra a posição dele. Tudo bem, quer ir por aí vai, mas não vou junto” (PEIXOTO apud BALBI,2009, p. 72).
} 
espetáculo um lado profundamente irracionalista, desenvolvido às últimas consequências, e um lado racionalista desenvolvido até as últimas consequências. (...) $\mathrm{O}$ tema que me interessava discutir: o furo da revolta pequeno-burguesa individualista. (PEIXOTO, 1989b, p. 67).

Essa combinação de diferentes modelos teatrais se expressava também através do elenco, em que atores do Oficina contracenaram com Gianfrancesco Guarnieri, então um dos mais importantes nomes do Teatro de Arena. Peixoto propositalmente colocava duas concepções diferentes em jogo, expressando o conflito estético que o Oficina então enfrentava. Havia uma linha racionalista conduzida pelo personagem principal e uma linha irracionalista aprofundada pelo coro (PEIXOTO, 2002, p. 198). Essa separação do elenco em funções (protagonista e coro) organizando dois registros diferentes de atuação em algo se assemelha ao Sistema Coringa proposto por Boal, que ele acabara de experimentar ao trabalhar com o Arena ${ }^{28}$.

Curiosamente, a viagem realizada logo antes com o Arena aos Estados Unidos também colocou Peixoto em contato com “a contestação americana, vivia no Village com hippie (sic), aquela loucura toda, sentindo aquela explosão num momento privilegiado” (PEIXOTO, 1989b, p. 67). A influência da contracultura norte-americana concretizou-se em Don Juan musicalmente: foi criada uma ópera-rock. Um disco do Rolling Stones foi uma das grandes inspirações da montagem. Embora rompendo com o Teatro Oficina, o diretor lhe prestava homenagem, e nutria um interesse por novas formas de contestação social que surgiam. Hoje observamos criticamente o processo através do qual algumas dessas formas de contestação foram capturadas como mercadoria. À época o rock já enriquecia a indústria fonográfica, mas seguia expressando o "não" de uma juventude estadunidense que se rebelava contra a sociedade de consumo, a família tradicional burguesa, a guerra do Vietnã. O problema não era a revolta, mas a sua reclusão em um individualismo pequeno-burguês.

\section{Teatro de Arena: um outro coro, o Sistema Coringa e o problema do Herói}

Enquanto era integrante do Oficina, Peixoto também trabalhou como ator no Teatro de Arena, realizando viagens para o Peru, México e Estados Unidos com os

\footnotetext{
${ }^{28}$ O procedimento também faz lembrar a divisão entre "representativos" e "coro" vivida pelo Oficina em Galileu Galilei. Mas Peixoto faz menção ao "personagem principal” como condutor da linha de raciocínio lógico (PEIXOTO, 2002, p. 198). A afirmação remete à valorização da função protagônica defendida por Augusto Boal em seu Sistema Coringa. Veremos mais sobre o Sistema Coringa a seguir.
} 
espetáculos Arena conta Zumbi (de Guarnieri e Boal) e Arena conta Bolívar (de Boal), nos anos de 1969 e 1970. Ao visitar os Estados Unidos, durante essa turnê, Fernando Peixoto estudou mais sobre Bertolt Brecht e conheceu o encenador e estudioso Eric Bentley, que lhe forneceu documentos sobre a estadia de Brecht no país. Também entrou em contato com a contracultura norte-americana que, como vimos, o influenciou na encenação de Don Juan - e não parou de lhe provocar desde então.

Arena conta Zumbi já havia sido encenada no Brasil em 1965, e foi a peça em que o Teatro de Arena começou a criar o Sistema Coringa. Já Arena conta Bolívar (musical de 1970 orientado pelo mesmo sistema) foi impedida de estrear no Brasil por conta da censura, e foi apresentada apenas no exterior.

O Sistema Coringa foi estruturado por Augusto Boal - em textos e em cena - em 1967, por ocasião da encenação do musical Arena conta Tiradentes. Ao publicar a dramaturgia Boal incluiu artigos em que discorria sobre o Sistema ${ }^{29}$, tornando-o um modelo com possibilidade de ser reproduzido por outros artistas teatrais. Ele propunha soluções ao mesmo tempo estéticas e econômicas ao teatro brasileiro da década de 1960.

Do ponto de vista estético, Boal inspirou-se no teatro dialético de Bertolt Brecht. Propôs o uso de quatro técnicas básicas para a criação de peças brasileiras de caráter épico. Eram elas: a desvinculação entre ator e personagem; o agrupamento dos atores em uma perspectiva única de narradores; o ecletismo de gênero e estilo; e o uso da música $^{30}$. No que se refere à atuação, especialmente as duas primeiras técnicas estavam ligadas a determinadas funções. O elenco se distribuía na função protagônica, na função do Coringa, e em dois coros (coro deuteragonista e coro antagonista).

A função protagônica era a única em que a vinculação total entre ator e personagem seria desejável. O ator que assumisse essa função deveria trabalhar em um registro de interpretação naturalista, de forma a criar empatia nos espectadores. Boal estava preocupado em reconquistar o interesse dos espectadores pelo teatro, o que em

\footnotetext{
${ }^{29}$ Já no programa do espetáculo Boal publicou dois textos em que introduzia o Sistema Coringa, mas foi no livro que ele incluiu um ensaio mais completo a respeito do Sistema e de sua relação com a trajetória do Teatro de Arena até então. Posteriormente esses artigos foram publicados em seu livro "Teatro do Oprimido e outras poéticas políticas”.

${ }^{30}$ É interessante observar que a dramaturgia de Calabar utiliza duas dessas técnicas (ecletismo de gênero e estilo e uso da música), e não utiliza as outras duas (desvinculação ator-personagem e agrupamento de todos os atores em uma única perspectiva de narradores). A partir desse ponto de partida produzimos uma análise sobre as semelhanças e diferenças entre Arena conta Zumbi, Arena conta Tiradentes e Calabar, em um artigo publicado na Revista Sala Preta. HOTIMSKY, Nina. Zumbi e Tiradentes, Calabar. Sala Preta, 18(2), 2018, p. 84-94.
} 
seu ensaio é relacionado tanto com problemas econômicos - "por que debanda o público? (...) Falta dinheiro no bolso da plateia, como falta capim no estômago do cavalo: ambos emagrecem” (BOAL, 1967, p. 12) - como com um questionamento sobre o lugar social do teatro. Para ele a plateia que mais importava atrair era a massa popular. O Coringa, ao contrário do protagonista, era responsável por uma mediação crítica. Ele desempenhava diversas funções, entre elas a de comentar a ação com a consciência do autor.

Os demais atores estariam distribuídos nos dois coros acima mencionados, um que daria apoio ao protagonista e o outro que agiria contra ele. A partir dessa opção, um recurso frequentemente identificado como épico ou dialético era implicado diretamente com os desejos e dificuldades do protagonista. Como observou Paulo Bio, "a forma coral, que estruturalmente aponta para fora do conflito intersubjetivo, aqui ajudaria a ecoá-lo” (BIO, 2018, p. 191). Apesar dessa divisão em função da fábula, haveria também uma unidade no coro:

“O espetáculo deixava de ser realizado segundo o ponto de vista de cada personagem e passava, narrativamente, a ser contado por toda uma equipe, segundo critérios coletivos: "Nós somos o Teatro de Arena" e "nós, todos juntos, vamos contar uma história, naquilo que semelhantemente pensamos sobre ela". Conseguiu-se assim um nível de “interpretação coletiva”” (BOAL, 1977, p. 189).

Esse era um coro diferente do coro contracultural de Roda Viva trabalhado por Zé Celso. Vale lembrar que o coro do Arena veio primeiro, e era um modelo com o qual Zé Celso dialogava: Arena conta Zumbi é de 1965, a sistematização do Sistema Coringa veio com Tiradentes em 1967, e Roda Viva foi encenada em 1968. Em Roda Viva interessava romper a barreira entre palco e plateia, tocar fisicamente os espectadores, provoca-los sobre uma outra forma possível de viver no aqui e agora. O coro do Arena também estava próximo aos espectadores, que rodeavam os atores por todos os lados em um pequeno teatro. Mas sua interpretação coletiva estava a serviço de uma história ficcional a ser narrada, uma fábula que gerava reflexões sobre os processos históricos reais.

Importava a Boal que os atores houvessem pensado sobre a história que narravam e estivessem de acordo sobre ela. Para Zé Celso o coro interessava por fomentar eros, a festa, o ritual, uma experiência sensorial (em Galileu Galilei esse coro inclusive interrompia o andamento lógico da dramaturgia, ao alongar a cena do 
carnaval). Certos aspectos da individualidade dos artistas do coro também interessavam a Zé Celso: "E cada um deles trazia o embrião de todas as revoluções que foram acontecendo depois, separadamente: a revolução ecológica, a sexual, a religiosa, a estética, a alimentar, da revolução das drogas... Um pouco em cada corpo” (CORRÊA, 2012, p. 6). O ator do coro de Roda Viva, mesmo ao integrar um coletivo, trazia em sua identidade contestações comportamentais específicas ${ }^{31}$. Já o coro do Arena dividia com os espectadores uma contestação histórica veiculada pela fábula que era narrada.

Vale lembrar que Fernando Peixoto afastou-se gradativamente do Teatro Oficina por conta da crise desembocada pelo conflito entre “coro” e “representativos”. Quando foi trabalhar com o Arena em 1969 e 1970, ele ainda era membro do Oficina. Ou seja: Peixoto viveu na pele, como ator, a experiência de estar em cena convivendo com dois modelos completamente diferentes de coralidade $^{32}$. Essa experiência foi sendo elaborada em seus trabalhos posteriores como encenador.

Há mais um aspecto do Sistema Coringa com o qual Calabar (primeiramente a dramaturgia, e por consequência a encenação) dialogou diretamente. Trata-se da questão do herói, abordada na apresentação do Sistema no subitem Quixotes e Heróis. Boal começa dialogando com a obra de Brecht, que em poemas e peças questiona a figura do herói. Em Vida de Galileu o protagonista afirma: “Infeliz a terra que precisa de heróis” (BRECHT, 1991, p. 154). Boal, que em muito se inspirava no dramaturgo alemão, afirma que "Brecht não fustiga o heroísmo “em si”, pois tal não existe, mas apenas certos conceitos de heroísmo e cada classe tem o seu” (BOAL, 1977, p. 220).

Havia aqui uma disputa em torno do personagem histórico Tiradentes, que a Ditadura Civil-Militar (representando os interesses da classe dominante) buscava transformar em um "herói brasileiro" em seus moldes. O discurso oficial narrava um Tiradentes Mártir da Independência. Mas o nacionalismo apregoado pela ditadura não era "neutro" - carregava os seus interesses e planos para o país. Arena conta Tiradentes fazia o caminho oposto, retratando Tiradentes como um revolucionário que lutou contra um regime opressivo e em prol dos direitos de seu povo. Na analogia com 1967 que a

\footnotetext{
${ }^{31}$ Com o cuidado de não cometermos um anacronismo, seria possível relacionar essa proposta com certos caminhos apontados a partir de 1968, encampados posteriormente por formas de política identitária.

${ }^{32}$ No caso de Galileu Galilei (1968), como vimos, Peixoto estava em cena como um dos personagens da dramaturgia de Brecht, chamado pejorativamente de "representativo" pelos atores do coro. Mesmo assim, contracenava com esse coro. Também em Na Selva das Cidades (1969) esteve em cena como ator lidando com essa forma de interpretação pesquisada por Zé Celso desde então, "um teatro mais despojado e mais entregue, marcado pelo caos e pelo irracionalismo” (PEIXOTO, 2002, p.197).
} 
peça sugeria, Tiradentes não estaria ao lado do Regime Militar, mas de quem lutava contra ele.

Boal finaliza o seu texto retomando o diálogo com Bertolt Brecht: "Brecht cantou: "Feliz o povo que não tem heróis. Concordo. Porém nós não somos um povo feliz. Por isso precisamos de heróis. Precisamos de Tiradentes” (BOAL, 1977, p. 223). Para ele, a exortação de heróis revolucionários contribuía para um novo momento histórico em que a luta era necessária. Tiradentes (e Zumbi e Bolívar, também contados pelo Arena com a participação de Peixoto) poderiam inspirar novos lutadores e dar força àqueles que já haviam perdido batalhas recentes. Mas o fato de Arena conta Bolívar não ter sido apresentada dentro do Brasil já chama a atenção para o endurecimento vivido após 1968, com o AI-5. Os revolucionários reais eram massacrados, e mesmo a exortação poética da resistência era impedida de ocorrer em nossas terras.

Anatol Rosenfeld, importante crítico teatral, travou ainda em 1967 um debate com Boal a respeito da necessidade e da viabilidade de um herói contemporâneo ${ }^{33}$. Para Rosenfeld (1996, p. 35), “não se pode simplificar apenas o herói. É preciso simplificar toda a realidade que o cerca para reconstruir a época mítica”. Assim, a presença do herói não contribuiria para a interpretação complexa da realidade da época. O apelo ao mito em um teatro que deseja analisar uma situação concreta e histórica não conseguiria evitar a mistificação.

O crítico também questionava a necessidade de um protagonista interpretado através de um registro de atuação naturalista, como se essa fosse a única forma de gerar a empatia dos espectadores. Para ele isso seria uma má leitura das propostas de Bertolt Brecht, e poderia pender para uma concepção irracionalista (por subentender que a razão teria uma característica fria, incapaz de produzir empatia). Rosenfeld defendia que a obra de Brecht não opunha razão e emoção, tampouco eliminava a empatia.

Outro problema do herói seria o fato de ele ser especial, insubstituível. Concentrar os sonhos de transformação nas ações de uma figura heroica teria como consequência o retrato das massas como passivas. Um líder excessivamente forte apontaria para o populismo.

\footnotetext{
33 “O primeiro texto, Heróis e coringas, foi publicado na Revista Teoria e Prática em 1967 e o segundo, $O$ herói humilde, no Caderno Especial no 2 (Teatro e Realidade Brasileira) da Revista Civilização Brasileira de 1968. Ambos os ensaios foram reunidos mais tarde no volume $O$ mito e o herói no moderno teatro brasileiro". (BIO, 2018, p. 125).
} 
Ao mesmo tempo, Rosenfeld entende a aposta de Boal no mito e no herói. Percebe que o teatro popular tem grande potência de formular críticas, mas que há momentos em que além da análise os artistas sentem a necessidade de colocar no palco proposições de mudança, expectativas de uma outra realidade, a exaltação da ação. É por isso que Rosenfeld imagina como uma possível saída a construção de um "herói humilde”, que deveria ser "um indivíduo extremamente comum, por assim dizer, e apesar disso sugerir virtualidades humanas extraordinárias. Deveria ser imbuído do ethos de quem se sabe substituível” (p. 46). O herói contemporâneo precisaria incluir essas características tradicionalmente vistas como pouco heroicas.

Há nos textos do crítico, assim, uma segunda possibilidade de trato com o herói. Rosenfeld elenca recuperações modernas do mito no âmbito artístico que foram bemsucedidas, especialmente obras da literatura moderna: “Nos maiores exemplos, o mito é abordado criticamente ou é, ele mesmo, de certo modo o próprio tema da obra" (ROSENFELD, 1996, p. 37). Essa abordagem pode ser relacionada com a dramaturgia de Calabar, que é centrada em um herói ausente. Trataremos disso mais adiante.

Do ponto de vista econômico, Boal formulava o Sistema Coringa como um "sistema permanente de fazer teatro (estrutura de texto e estrutura de elenco)" (BOAL, 1977, p. 197). A forma narrativa e a possibilidade de os atores desempenharem mais de um personagem contribuía para a adequação dos mais diversos textos ao mesmo grupo de artistas. Inclusive textos com características épicas, que se dispunham a lidar um número maior de personagens para colocar em cena situações de caráter público. A proposta visava liberar as companhias da necessidade de contratar atores extras, o que encarece qualquer produção. É importante observar que essa proposição foi gerada antes do AI-5, quando diferentes companhias teatrais que eram críticas à situação social (como os próprios Teatro de Arena e Teatro Oficina) ainda conseguiam produzir sem tantos entraves.

O envolvimento de Peixoto com duas peças orientadas pelo Sistema Coringa coloca algumas questões essenciais para a compreensão de Calabar. São elas: qual coro se deseja? Qual forma de produção se deseja? Como retratar o povo em cena? Precisamos de heróis para discutir a realidade nacional?

$\underline{\text { Fim de um ciclo histórico e afirmação de Peixoto como encenador: } 1972 \text { e } 1973}$ 
Segundo Décio de Almeida Prado, o início da década de 1970 foi marcado por uma ausência de modelos claros para a produção teatral no Brasil.

Com o desaparecimento quase simultâneo do Teatro de Arena e do Teatro Oficina, ocorrido por volta de 1972, terminava um ciclo histórico. Durante três decênios, havíamos tido uma companhia-padrão, que encabeçava a vanguarda e pela qual se julgava tudo o que se fazia no momento. Primeiro, no Rio, Os Comediantes, Dulcina, Mme Morineau. Depois, em São Paulo, o TBC, o Arena, o Oficina. Em meados de setenta, abalado o consenso que fizera a força daquelas companhias, entrávamos numa fase de tateamento e indecisão. A verdade é que depois de tanto ardor revolucionário, político e estético, tantas experiências apontando para as mais disparatadas direções, ninguém sabia ao certo qual deveria ser o próximo passo. (PRADO, 2009, p. 119).

Peixoto também afirmou em seus textos que o Oficina e o Arena foram os mais importantes grupos teatrais de determinado momento, e funcionavam como dois lados da mesma moeda. Ambos estavam preocupados em refletir criticamente sobre a realidade brasileira: o Arena através de sua dramaturgia, e o Oficina mais focado em buscar uma linguagem nacional da encenação (PEIXOTO apud BALBI, 2009, p. 58). O encerramento desse ciclo se deu de maneira violenta: Augusto Boal e Zé Celso sofreram prisões e tortura, e foram obrigados a deixar o país. Ambos deram seguimento às suas pesquisas artísticas no exílio, e eventualmente retornaram ao Brasil ${ }^{34}$. Mas o fato é que nesse ponto, que Prado situa em 1972, os artistas que seguiram produzindo nessas terras precisavam tatear possibilidades. E a pesquisa se dava em condições profundamente adversas: desde o AI-5 a censura sufocava as produções, o Estado concedia pouquíssimo incentivo às iniciativas culturais, havia uma crise financeira e de público.

Curiosamente, 1972 é também um ano importante para a consolidação de Fernando Peixoto como encenador. Até ali, sua maior participação nos espetáculos se dava como ator. Ele havia dirigido apenas duas peças semiprofissionais (em Porto Alegre) e duas peças profissionais (dentro do Teatro Oficina), além de um show musical: O Canto Livre de Nara, em 1968. Em entrevista, ele justificou: “eu fiquei meio órfão com os exílios do Zé Celso e do Boal e disse: 'o único diretor com quem eu quero trabalhar sou eu mesmo’” (PEIXOTO, 1989b, p. 68).

34 Paulo V. B. Toledo realizou uma bonita tese sobre a trajetória de Augusto Boal e Zé Celso a partir do golpe civil-militar. TOLEDO, Paulo Vinicius Bio. Debates sobre teatro e sociedade após o golpe de 1964: reflexão e trabalho teatral de José Celso Martinez Corrêa e Augusto Boal. Tese (Doutorado em Teoria e Prática do Teatro) - ECA, USP. São Paulo, 2018. 
Em 1972 Peixoto dirige quatro espetáculos. Dois deles, Tambores na noite (de Bertolt Brecht) e A Semana (Carlos Queiroz Telles ${ }^{35}$ ), foram realizados com o Grupo Núcleo - antes chamado de Núcleo Dois do Arena ${ }^{36}$. Esse grupo foi formado a partir de uma oficina no interior do Arena em 1969, e estreou Teatro Jornal - Primeira Edição em 1970. O trabalho do Grupo Núcleo com Peixoto se deu no espaço do Teatro São Pedro, em parceria com o produtor Maurício Segall. Mais tarde, parte do grupo decidiu aprofundar seu viés político através de uma ida às periferias de São Paulo ${ }^{37}$, optando por uma prática teatral militante fora do circuito profissional. Acompanhar as experiências do Núcleo Independente (como passaram a se chamar nesta nova etapa) em paralelo com os trabalhos seguintes de Peixoto pode lançar luz sobre algumas das inquietações que ele expressa nas fitas sobre Calabar. O encenador se incomodava com os limites impostos pela forma de produção profissional, mas é claro que as propostas de teatro e militância no contexto da ditadura civil-militar também encontravam dificuldades e contradições.

O terceiro espetáculo dirigido por Peixoto em 1972 foi Frei Caneca, de Carlos Queiroz Telles, que estreou na sala grande do Teatro São Pedro, “com parte do elenco do Núcleo e parte de atores convidados ou testados” (PEIXOTO, 1989d, p. 138). Além destes, é do mesmo ano sua direção de “O processo de Joana d’Arc”, de Bertolt Brecht, na Escola de Artes Dramáticas.

O ano seguinte, 1973, seguiu intenso para Peixoto como encenador. Antes de dirigir Calabar, ele estreou Frank $V$ (do autor suíço Friedrich Dürrenmatt) com a companhia do Teatro São Pedro e Um grito parado no ar (texto de Gianfrancesco Guarnieri) com a Othon Bastos Produções Artísticas. Foram sete direções em apenas dois anos. Não caberá aqui uma análise profunda de tantos espetáculos, mas há alguns aspectos que merecem ser mencionados, por sua correlação com Calabar e com as reflexões produzidas então por Peixoto.

\footnotetext{
${ }^{35} \mathrm{O}$ dramaturgo Carlos Queiroz Telles foi um dos fundadores do Teatro Oficina, grupo que Fernando Peixoto também integrou.

${ }^{36}$ Segundo Fernando Peixoto: "No Arena havia um Núcleo Dois, que se constituiu em um grupo profissional independente, o Grupo Núcleo. Conseguiram um esquema de co-produção com o produtor Maurício Segall e me convidaram para fazer o espetáculo no Studio São Pedro” (PEIXOTO, 1989d, p. 138). Há diferentes narrativas sobre a passagem do Núcleo Dois do Arena para o Grupo Núcleo, que mais tarde se denomina Núcleo Independente. Essa trajetória vem sendo estudada pelo pesquisador Ademir de Almeida em seu mestrado, ainda não finalizado.

37 Silvana García estudou essa e outras iniciativas de Teatro Independente em sua tese. GARCÍA, Silvana. O Teatro Independente - A Intenção do Popular no Engajamento Político. Tese (Mestrado em Artes Cênicas) - ECA, USP. São Paulo, 1987.
} 
Um aspecto a se observar é a inserção do diretor em contextos em que havia um grupo relativamente estável, certas pessoas que nutriam uma perspectiva de continuidade de trabalho. Já falamos do Grupo Núcleo. O próprio Teatro São Pedro foi um polo da produção teatral de esquerda naquele momento em que Arena e Oficina desapareciam. Ali se constituiu “um trabalho de produção regular, um projeto de grupo. (...) Maurício Segall se preocupou em manter uma programação e um elenco permanente. Foi uma experiência ainda pouco estudada. E de grande importância nesses anos” (PEIXOTO, 1989d, p. 138). Beatriz Segall e Maurício Segall arrendaram o antigo teatro, que corria risco de demolição. Realizaram reformas e em 1969 criaram a empresa São Pedro Produções Artísticas, inicialmente em parceria com Fernando Torres - que mais tarde produziu Calabar. A partir de 1970 o espaço passou a contar com duas salas: o tradicional teatro de seiscentos lugares e mais uma sala menor, de duzentos lugares, o Studio São Pedro. Maurício Segall foi militante da Ação Libertadora Nacional (ALN) à época, e chegou a ser preso e torturado. Durante sua prisão, Beatriz manteve em funcionamento a São Pedro Produções Artísticas.

Com o fechamento do Teatro de Arena, em 1971, o Núcleo passou a trabalhar no Teatro São Pedro e colaborar com suas produções; há peças em que esses dois grupos se confundem ${ }^{38}$. Peixoto considera 1973 como um marco de “organicidade” para o grupo de teatro do São Pedro, que passou a contar inclusive com uma comissão de discussão de repertório formada por artistas e intelectuais (PEIXOTO, 1989d, p. 139). Foi essa comissão que decidiu pelo texto Frank $V$, que não era o favorito nem de Fernando e nem do produtor Maurício Segall. O diretor vê esse fato como um marco: “O meu projeto estava então ligado ao projeto de um grupo. O fato de eu ter sido voto vencido no projeto significa, mais do que nunca, que estava perfeitamente integrado no grupo” (PEIXOTO, 1989b, p. 69). Posteriormente, passou a considerar Frank V um de seus trabalhos preferidos.

Além das parcerias com o Teatro São Pedro e com o Grupo Núcleo (então acolhido pelo mesmo Teatro), houve também o trabalho de Peixoto com a Othon Bastos Produções Artísticas. Tratava-se de uma empresa teatral criada em 1970, que àquela altura lidava com limitações econômicas, mas que marcou o período por seu repertório crítico à realidade social brasileira. Um grito parado no ar foi uma encomenda dos

38 Sérgio Mamberti falou em entrevista sobre a grande admiração de Maurício Segall (produtor do Teatro São Pedro) pelos jovens atores do Grupo Núcleo. Seu depoimento ajudou a compreender a proximidade entre os dois grupos no período. MAMBERTI, Sérgio. Entrevista sobre Calabar de 1980. Entrevistadora: Nina Hotimsky. São Paulo, jan. 2019. 
produtores a Guarnieri, escrita pelo dramaturgo em diálogo com a equipe que o montaria: “Terminou o texto para nós, escreveu diretamente para o elenco que dispunha, chegou a dar o nome do diretor, um personagem da peça, de Fernando (...)”. (PEIXOTO, 1989d, p. 139).

Do ponto de vista formal, um dado importante das direções de Peixoto em 1972 e 1973 é a predominância de peças musicais, ou nas quais a música cumpria papel fundamental. Tambores na noite e Um grito parado no ar tinham canção de Toquinho em parceria com Gianfrancesco Guarnieri; A Semana tinha músicas de Toquinho e Chico Buarque de Hollanda ${ }^{39}$. Frei Caneca tinha músicas de Carlos Castilho, e houve provavelmente um estudo de música litúrgica, já que há partituras de músicas religiosas junto com os materiais da peça no Arquivo Fernando Peixoto.

Frank V, uma comédia-musical-policial (segundo informação no programa), tinha composições de Paul Burkhard, direção musical de Paulo Herculano e música ao vivo. Os cadernos de direção de Peixoto para essa peça revelam que o seu trabalho com a musicalidade era inspirado pelo pensamento de Bertolt Brecht. Nesses cadernos, consta a anotação: “Localizar o gestus de cada música” ${ }^{40}$. Esse procedimento muito provavelmente se baseava no texto Acerca da música-gesto, escrito pelo encenador alemão.

Brecht define a música-gesto como um princípio artístico: o "princípio de sempre procurar o "gesto” que lhe permita assumir, ao criar a música, uma posição política. Para assumir essa posição necessita elaborar um "gesto” social (...), gesto que permite tirar conclusões que se apliquem às condições dessa sociedade” (BRECHT, 2005, p. 238). Ele estava preocupado em utilizar a música a serviço de um teatro crítico, muito diferente de formas já então consagradas de teatro musical comercial. Nas formas hegemônicas de teatro musical, as canções costumam servir ao desenvolvimento do conflito intersubjetivo, ou à expressão dos sentimentos íntimos das personagens; sua função é dramática ou lírica. Para Brecht, pelo contrário, as canções poderiam ajudar a epicizar a cena, ao inscrever as personagens em um contexto social em disputa.

39 A participação de Chico Buarque nesse projeto precisaria ser melhor esclarecida. Seu nome consta no programa do espetáculo, embora Peixoto afirme em um de seus textos que não conseguiu as músicas de Chico: "Tentei música de Chico Buarque, mas acabei com música de Toquinho”. (PEIXOTO, 139b, p. 138).

${ }^{40}$ Gestus significa "gesto" em alemão, língua na qual Bertolt Brecht produziu. Caderno de direção manuscrito disponível no Arquivo Fernando Peixoto do Centro de Documentação e Pesquisa da Funarte. 
A montagem de Frank $V$ pelo Teatro São Pedro foi assistida pelo importante crítico francês Bernard Dort ${ }^{41}$, estudioso do teatro épico brechtiano. Dort escreveu sobre a direção de Peixoto: "Sua ópera de um banco particular é na verdade a descrição irônica de um sistema de exploração e opressão capitalista (...). Se Peixoto renuncia a aos efeitos de teatro, ele reencontra o teatro através de uma ironia, de um senso muito agudo do gesto adequado"42. A ideia de uma ópera trabalhada a partir de "gestos adequados” também alude ao conceito de música-gesto. Quando o encenador trabalhou Calabar, no mesmo ano de 1973, a precisão do gestus seguiu sendo sua principal preocupação no trabalho com as canções. O processo de Joana D’Arc parece ter sido a única das sete peças encenadas entre 1972 e 1973 a não contar com composições originais ou com música ao vivo (embora não tenhamos encontrado materiais documentais que o afirmem com certeza).

Outro aspecto interessante dessa fase é a escolha das dramaturgias. Foram quatro peças de autores nacionais (Carlos Queiroz Telles, Gianfrancesco Guarnieri, Chico Buarque e Ruy Guerra), duas peças de Bertolt Brecht e apenas uma de outro autor estrangeiro, Durrenmatt, escolhida justamente por sua predisposição de discutir problemas sociais e econômicos da época. Sobre a encenação de Frank $V$, de Durrenmatt, Edélcio Mostaço (que foi aluno de Peixoto na Escola de Comunicações e Artes da Universidade de São Paulo) observou: “Estão aqui esboçadas as linhas mestras que impulsionaram a encenação de Fernando: fazer com que um texto não-brechtiano adquirisse todos os valores defendidos pelo mestre da dramaturgia não-aristotélica” (2014). Também em Calabar o encenador incutiu elementos epicizantes nem sempre previstos pela dramaturgia.

A operação de dar a ver determinada situação social a partir das mais diversas dramaturgias foi muito desenvolvida pelo encenador Roger Planchon, na França. Peixoto tomou contato com seu trabalho quando ainda era membro do Teatro Oficina, em sua viagem de pesquisas à Europa. Mostaço comenta a influência de Planchon na encenação de Frank V:

\footnotetext{
${ }^{41}$ Bernard Dort, teórico do teatro francês que dedicou parte importante de sua produção ao teatro épico brechtiano, foi também amigo pessoal de Fernando Peixoto.

${ }^{42}$ A crítica de Bernard Dort ao espetáculo Frank $V$ foi publicada em artigo intitulado "A crítica do nosso teatro, por um francês", e consta no Arquivo Fernando Peixoto. Infelizmente o recorte de jornal ali encontrado não permite extrair mais informações sobre a publicação: não constam no recorte a data do artigo e nem o nome do jornal.
} 
Maurício e Beatriz Segall ofereceram todas as condições para que a produção se completasse com luxo e qualidade artística: músicos em cena, tecidos de alta qualidade, smokings e fraques impecáveis para os homens e vestidos de fino corte para as mulheres. Segundo Fernando, tais itens materializavam, de um ponto de vista histórico, as relações de classe das criaturas cênicas; ou seja, ele agia como se estivesse na pele de Planchon dirigindo molierescas figuras aristocráticas. "Brecht não faria de outro modo”, me dizia baixinho (MOSTAÇO, 2014).

O período de afirmação de Peixoto como encenador também serviu para que ele testasse no próprio trabalho as influências de artistas que admirava. Ao encenar Calabar ele seguiu tendo em mente o trabalho de Planchon. Tanto em Frank $V$ como em Calabar, uma produção com recursos viabilizava os investimentos necessários para essa forma de materializar as relações de classe - havia elencos numerosos e figurinos de alta qualidade, por exemplo.

As duas peças de Carlos Queiroz Telles dirigidas por Peixoto, A Semana e Frei Caneca, eram peças históricas. Elas partiam de um procedimento parecido com o adotado nos musicais do Arena, e posteriormente em Calabar: a figuração de um momento do passado brasileiro como forma de discutir o presente. Frei Caneca é especialmente semelhante, já que elege como protagonista um homem que exerceu resistência ao colonialismo e conspirou contra os poderes instituídos. Em texto do programa, Peixoto se refere a Frei Caneca como “um homem de ação, empenhado no combate à injustiça e à miséria, soldado das batalhas pela libertação do país”. Afirma ainda que a peça é a "biografia de um herói, num país onde eles são necessários” 43 , colocando-se assim ao lado de Augusto Boal nos debates sobre a necessidade do herói no teatro brasileiro. A crítica especializada identificou esse tema sensível e dialogou com ele. Uma das críticas jornalísticas disponíveis no Arquivo Fernando Peixoto intitula-se "Peça conta a história de um herói incômodo"44, e outra, de Sábato Magaldi, afirma que Frei Caneca é pouco citado nos livros de História por se tratar de um "herói menor, que desafiou D. Pedro I, um herói maior, dentro dos conceitos vigentes” (MAGALDI, 1972).

Houve uma preocupação de produzir um estudo histórico, o que se pode verificar no programa do espetáculo - que oferecia ao espectador uma cronologia da

\footnotetext{
${ }^{43}$ Programa do espetáculo: Frei Caneca, Teatro São Pedro, 1972.

44 Essa crítica consta no Arquivo Fernando Peixoto. Infelizmente, trata-se de um recorte do jornal guardado pelo diretor, de forma que não é possível averiguar informações tais como nome do jornal, data da matéria ou autor.
} 
vida de Frei Caneca - e nos cadernos de direção ${ }^{45}$. Essa abordagem por vezes se refletia também em um certo "historicismo" na encenação. O cenário e os figurinos de Frei Caneca foram produzidos por Helio Eichbauer, que posteriormente trabalhou em Calabar. É possível encontrar semelhanças entre as criações visuais de ambos os espetáculos: o cenário tinha cordas, bandeiras e brasões. Ele mesclava um estudo histórico e uma aposta na simplicidade, que se expressa em linhas geométricas sintéticas e em elementos cenográficos que podiam se transmutar em outros com facilidade. Essas tendências voltariam a aparecer em Calabar. Quanto aos figurinos, há no Arquivo Fernando Peixoto os desenhos de Eichbauer para os figurinos do "Povo" de Frei Caneca $^{46}$, que possivelmente possuem parentescos com os figurinos do "Povo" de Calabar: a predominância de tons ocres, beges e preto, os retalhos, a presença de saias compridas para caracterizar mulheres simples e religiosas, os objetos que remeteriam aos ofícios dos personagens. Por fim, havia em Frei Caneca a presença de uma inspiração na cultura popular: há um desenho de um homem montado em um cavalo

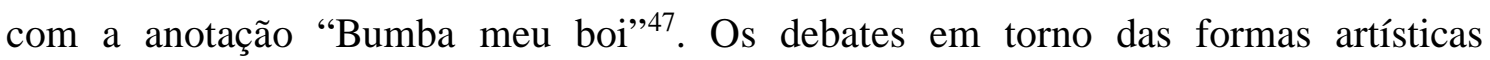
populares realizados nos CPCs seguiram ecoando nas realizações do teatro politizado. Mais tarde, em Calabar, teríamos o Boi voador.

Um último dado dessa fase a se assinalar foi a solidificação de parcerias que chegariam a Calabar, e que por vezes durariam muitos anos ainda: com o cenógrafo e figurinista Helio Eichbauer ${ }^{48}$, o diretor assistente Mário Masetti, o cineasta Ruy Guerra $^{49}$, e com o compositor Chico Buarque ${ }^{50}$. Havia uma pesquisa de linguagem em curso, e a preocupação de seguir debatendo criticamente a realidade brasileira, mesmo sob censura. Zé Celso e Augusto Boal faziam falta, assim como faziam falta o Teatro Oficina e o Teatro de Arena como companhias modelares. Mas o trabalho teatral continuava e novas alianças eram tecidas. Trataremos a seguir das especificidades em torno da produção de Calabar, única das sete peças do período que não chegou a estrear.

45 Consultados no Arquivo Fernando Peixoto - CEDOC - Funarte.

${ }^{46}$ Um desses desenhos está disponível como anexo da dissertação (Anexo D - desenho 1).

${ }^{47}$ Esse desenho está disponível como anexo da dissertação (Anexo D - desenho 2).

48 Helio Eichbauer já havia trabalhado com Peixoto quando este atuava em O Rei da Vela, mas nessa fase passa a trabalhar com ele como diretor.

49 Logo após desligar-se do Oficina, Peixoto foi trabalhar em cinema com Ruy Guerra, "amigo eterno e constante, exemplo de independência e lucidez" (PEIXOTO, 1989b, p. 68).

50 Chico já havia trabalhado com Peixoto no Teatro Oficina, no espetáculo Os Inimigos, mas aqui parece ter feito uma parceria com ele já como diretor. Ver nota de rodapé anterior. 


\section{Capítulo 1 - Uma produção interrompida}

Muitas das reflexões de Peixoto sobre Calabar estão ligadas aos limites e possibilidades estabelecidos por sua forma de produção. Peixoto avalia os impasses do trabalho teatral naquele momento, em que o teatro de esquerda inserido no circuito comercial passava por uma nova fase. Para dialogar com essas reflexões, é necessário entender o processo de produção da peça.

A dramaturgia de Calabar foi protocolada por Chico Buarque de Hollanda para análise da censura na Superintendência Regional do Estado do Rio de Janeiro em março de 1973. Como de praxe, o processo foi encaminhado à Divisão de Censura de Diversões Públicas (DCDP) em Brasília. O texto foi, a princípio, liberado com “cortes em pelo menos sete páginas da peça”, e proibição para menores de 18 anos, conforme documento de 16 de maio de 1973. Maria Luiza Barroso Cavalcante, uma das censoras que emitiu parecer, pediu atenção para algumas páginas por conterem "possíveis implicações de sentido político e analogia com a atualidade" 51 .

A peça era baseada na figura histórica de um soldado que mudou de lado na guerra: Domingos Fernandes Calabar, nascido em Pernambuco sob a colonização portuguesa, aliou-se aos holandeses que invadiram o Brasil no século XVII. Discutia-se o conceito de traição - algo que remetia às recentes tentativas de resistência contra o Regime Militar. O texto também colocava em pauta a questão da submissão do Brasil a interesses econômicos estrangeiros, tecendo analogias entre o passado colonial e a conjuntura da década de 1970.

Em junho do mesmo ano, os dramaturgos convidaram o diretor Fernando Peixoto para encenar a peça. Em julho, e por sugestão de Peixoto, definiram-se como produtores Fernanda Montenegro e Fernando Torres. Agosto foi o mês de pré-produção e escolha de elenco, e os ensaios foram realizados nos meses de setembro, outubro e início de novembro. A encenação estava quase pronta, e chegaram a ocorrer ensaios com a presença de diversos espectadores: o diretor registrou em seus diários a presença de “dois garotos vendendo balas e chocolates na plateia” (PEIXOTO, 1980, p. 13) no último ensaio.

\footnotetext{
51 "Parecer da TC da DCDP Maria Luiza Barroso Cavalcante”. Brasília, 16/5/1973. In Processo de censura da peça Calabar, de Chico Buarque e Ruy Guerra. DCDP/CP/TE/PT/CX444/1277
} 
Às vésperas da estreia, o espetáculo foi barrado pela censura de forma bastante atípica. A censura, mesmo que cheia de arbitrariedade, era regulada por etapas padronizadas. Miliandre Garcia descreve minuciosamente de que maneira os procedimentos burocráticos previstos pelos órgãos oficiais foram desrespeitados (GARCIA, 2012). Os prazos para emissão de parecer foram extrapolados; foram solicitados novos pareceres aos censores que, inicialmente, liberaram o texto; o Centro de Informações do Exército (CIE) emitiu um documento interno acusando a peça de subversão; o ensaio geral foi enfim suspenso e a peça adiada sine die (ou seja, sem que uma data futura fosse fixada) ${ }^{52}$. Em 13 de novembro de 1973, o que prevaleceu, nas palavras do encenador Fernando Peixoto, foi uma censura econômica: "mandaram dizer que não há proibição: apenas o texto ficará quatro meses preso para revisão. (...) E nós estamos definitivamente castrados. Agora resta encontrar o elenco para encerrar tudo" (PEIXOTO, 1980, p. 13).

O fim se deu pela impossibilidade econômica de manter os ensaios (por pelo menos mais quatro meses) sem previsão de estreia. O investimento já realizado na produção esperava ter retorno pela venda de ingressos. A produção empregava mais de 80 pessoas - não seria possível seguir pagando salários sem que o público pagante cobrisse esses valores. Apenas em 15 de janeiro de 1974 (aproximadamente dois meses após a produção ter sido desfeita) saiu a proibição oficial de Calabar para todo o território nacional. Em parte, por pressão dos artistas envolvidos: Ruy Guerra relatou, em entrevista concedida a nós, a importância política de o Estado assumir-se responsável pela censura. Com isso, afastou-se qualquer impressão de que o que houvera fora um cancelamento do espetáculo devido a dificuldades financeiras de uma produção mal administrada. Além disso, a oficialização da censura desobrigava os produtores (já cheios de prejuízo) de uma série de encargos trabalhistas. Houve ainda um embate judicial na tentativa de liberação do texto, protagonizado - sem grandes esperanças - pelos advogados de Chico Buarque e formalmente concluído em 19 de abril de 1974.

Descreveremos com mais vagar o curso destes acontecimentos, de forma a constituir uma visão do trabalho teatral (sob o ângulo produtivo) em torno da encenação de Calabar.

\footnotetext{
${ }^{52}$ Consta como anexo (Figura 16 - Anexo C) um documento emitido pela Polícia Federal que informa não ser possível marcar uma data para a realização do ensaio geral com a presença do censor o que, na prática, impedia a estreia do espetáculo.
} 
Trabalho inicial: o processo criativo da dramaturgia

Chico Buarque e Ruy Guerra já eram amigos, mas encontraram-se como parceiros teatrais pela primeira vez na peça $O$ homem de la Mancha. Tratava-se da tradução de Man of La Mancha (1965), musical de Dale Wasserman baseado no Dom Quixote de Cervantes, que já havia feito grande sucesso na Broadway. Flávio Rangel e Paulo Pontes traduziram o texto para o português, e Chico e Ruy se encarregaram de fazer versões das canções. A estreia brasileira ocorreu no Teatro Municipal de Santo André em 1972.

Sobre O homem de la Mancha, Fernando Peixoto (aqui em sua atividade de crítico) escreveu à época:

Flávio Rangel, antes de ter optado pela supervisão, já que a encenação original foi imposta pelos produtores (ou autores) norte-americanos, havia me contado rapidamente uma série de propostas que poderiam ter valorizado a peça (pretendia dinamitar a estrutura comercial do musical norte-americano, retrabalhando as canções e a partitura musical original; o texto de Man of $\mathrm{La}$ Mancha não significa nada de mais, mas seu tema permitiria uma encenação mais esclarecedora dos valores de liberdade tratados; (...) o espetáculo pertence ao universo do comércio teatral). (PEIXOTO, 2002, p. 188).

Ou seja: o desejo inicial de Rangel era o de adaptar um musical norte-americano, alterando sua forma (moldada pelos padrões da Broadway) e privilegiando o tema da liberdade. Este tema já havia sido discutido por ele em Liberdade Liberdade, peça musical escrita por Rangel em parceria com Millôr Fernandes e encenada pelo Grupo Opinião em 1965, claramente veiculada para criticar o então recente golpe militar.

É interessante notar que, no caso do musical O Homem de La Mancha, a censura não veio dos órgãos oficiais brasileiros. Foram os produtores norte-americanos que não permitiram a adaptação da peça aos interesses nacionais. Este modo de operar dos produtos importados da Broadway continua até hoje: a peça fora dos Estados Unidos é como uma franquia, que deve seguir os padrões da montagem original.

A crítica de Peixoto não considerou que a tradução das canções feita por Chico Buarque e Ruy Guerra operou algum grau de politização. Um bom exemplo é a canção principal, Imposible Dream, que no original tem por metáfora central a busca por tocar uma estrela inalcançável. Na tradução, a dupla incluiu versos inexistentes no original. Por exemplo: “Negar / Quando a regra é vender” (que sugere o tema da forma 
mercadoria); e “Sofrer a tortura implacável / Romper a incabível prisão” (uma provável alusão aos procedimentos dos militares no Brasil no início da década de 1970).

Parece significativo que o desejo de Chico e Ruy de escrever um musical brasileiro original tenha surgido nesta situação. A tradução das canções permitiu alguma criação, mas a arte da encenação foi limitada por padrões mercantis. Era melhor não depender da autorização de autores estrangeiros.

Foi então que a figura histórica de Calabar se tornou mote para um projeto conjunto de dramaturgia ${ }^{53}$. Em entrevistas da época, os autores relataram a grande quantidade de pesquisas exigidas pela empreitada. O trabalho de escrita estendeu-se por um ano, e incluiu o estudo de documentos históricos da época das invasões holandesas documentos em que o Domingos Fernandes Calabar real é mencionado.

Já nessa fase, contaram com a colaboração de André Midani, influente representante da Philips (empresa holandesa) no Brasil. Em sua autobiografia ele relata: “a pedido dos dois, entrei em contato com o embaixador da Holanda, solicitando sua interferência para que os documentos relacionados a Calabar, arquivados naquele país, fossem postos à disposição deles, o que foi acertado” (MIDANI, 2008, p. 122). Também foram feitas consultas com o historiador Sérgio Buarque de Hollanda (pai de Chico) e o estudo da obra Elogio da Loucura, de Erasmo de Rotterdam, com a qual Calabar - o Elogio da Traição tece intertextualidades.

O aprofundamento dos dramaturgos na pesquisa histórica os aproxima do modo de trabalhar de Fernando Peixoto. Na fase da primeira escrita eles ainda não sabiam quem seria o diretor da peça, mas partiam de preocupações semelhantes. Em parte, por continuar uma tendência bastante explorada como forma de driblar a censura, e já mencionada aqui: situar a ação da peça em outro tempo com o objetivo de discutir o presente. Há também pressupostos políticos envolvidos no estudo da História, possivelmente inspirados pelos debates sobre o teatro épico brechtiano na década anterior $^{54}$.

53 Em entrevista concedida a nós, Ruy Guerra desmentiu uma afirmação recorrente a respeito do texto: a de que teria idealizado Calabar como filme e que, por ausência de recursos, a trama tornara-se teatro: "Não foi requentado", afirmou.

${ }^{54}$ Desde meados da década de 1950, Brecht é uma referência, mais ou menos adotada, para os debates sobre representação da sociedade no teatro brasileiro. Um dos aspectos, entretanto, menos discutidos de sua influência no Brasil é seu interesse pelas relações entre teatro e História. Em seu Pequeno Organon para o Teatro, Brecht formula a necessidade de retratar o contexto de cada peça em sua relatividade histórica: "Nós pretendemos, porém, deixar às diferentes épocas a sua diversidade e não esquecer jamais a sua efemeridade, de forma que a nossa época possa ser também considerada efêmera” (BRECHT, 2005, 
Ruy Guerra os descreve nesse período: “a gente morava numa casa na Gávea. Era o nosso centro, o escritório; a gente trabalhava lá. (...) Nos lembro, Chico e eu, frente a frente, trocando páginas, reescrevendo ideias, ajustando palavras, afobados, frenéticos, quixotescos”. (GUERRA apud BORGES, 2017, p. 236). Os moinhos de vento já se viam no horizonte, mas a produção ocorria dentro de casa; segundo Chico: “era uma extensão da nossa amizade” (BUARQUE apud BORGES, 2017, p. 236). Texto finalizado, eles partiram para a etapa seguinte, necessariamente pública, coletiva e custosa: a montagem do espetáculo.

\section{$\underline{\text { Fernando Peixoto, encenador convidado }}$}

Em palestra realizada na Cinemateca de São Paulo, Ruy Guerra contou que o primeiro diretor sondado foi Amir Haddad, "mas o Amir Haddad pediu um ano pra ensaiar. Trabalhar, formar atores, escola. E nós tínhamos recém-acabado de passar um ano pra escrever aquilo, e pareceu uma certa sofreguidão esperar um ano pra ver o texto montado” (GUERRA, 2017). Em entrevista concedida a nós, Guerra completou: “A gente achava que era importante, não só em termos pessoais nossos de trabalho, mas em termos políticos também, que a peça não ficasse presa tanto tempo”55.

Os autores, então, convidaram Fernando Peixoto para dirigir. Em entrevista a Rosângela Patriota, Peixoto relatou que chegou a participar da finalização da dramaturgia: “Logo que começou o trabalho, quer dizer, antes de começar a ensaiar, antes de fazer os testes e tudo eu tive uma etapa de trabalho na dramaturgia mesmo. Eu lia o texto e discutia em reuniões muito frequentes com Chico e Ruy” (PEIXOTO, 2001). De fato, no caderno de direção de Peixoto (disponível no Arquivo Fernando Peixoto) há anotações a respeito dessas reuniões. Por exemplo:

Diário 5 de Agosto - Reunião com Ruy e Chico. Discutimos os problemas de estrutura do texto, eu coloco meus pontos de vista, Chico e Ruy concordam. Nos instalamos para trabalhar juntos no texto. Planeja-se uma troca de canções na 1a parte: Tatuagem por Cala a Boca e vice-versa. Outros pequenos detalhes

p. 142). O estudo da História, com suas contradições e pontos de mudança, deve ser cultivado por artistas que pretendem retratar o mundo como transformável.

${ }^{55}$ GUERRA, Ruy. Entrevista sobre Calabar. Entrevistadora: Nina Hotimsky. São Paulo, mar. 2018. 
de estrutura são mencionados a respeito da 1a parte. Inclusive, a necessidade de reduzir a sequência da latrina ${ }^{56}$.

Que o diretor tenha modificado o texto em conjunto com os dramaturgos é um dado importante para a compreensão do trabalho teatral. Ele revela que havia a abertura para o debate dentro da equipe, e que as funções especializadas permitiam algum grau de flexibilidade. Esse dado consta também nos depoimentos dos atores entrevistados, e será retomado mais adiante.

A escolha por Fernando Peixoto revela determinadas intenções a respeito da encenação. Como vimos, Peixoto vinha de uma intensa trajetória como ator e diretor, trabalhando com grupos importantes - o Teatro Oficina, o Arena, o Teatro São Pedro. Foi esse caminho profissional que o colocou em contato com os dramaturgos de Calabar em trabalhos anteriores. Nos últimos anos, havia encenado peças em que a presença da música ${ }^{57}$ era fundamental, dando-lhe estofo para lidar com mais uma peça musical. Além disso, ele era reconhecido como alguém que trabalhava para a construção de um teatro crítico no Brasil, tanto através dos estudos e montagens de peças de Bertolt Brecht, como a partir do incentivo aos dramaturgos nacionais. A dramaturgia de Calabar já apresentava predisposições dialéticas, que foram desenvolvidas nos ensaios pelo trabalho do encenador.

Ao mesmo tempo, Peixoto possuía uma boa abertura para a construção coletiva do discurso teatral. Em seu texto "Sete notas (pessoais) sobre a encenação no Rio em 1973”, em que reflete justamente sobre o trabalho de diferentes encenadores no ano em que Calabar foi ensaiado, afirma que “cada espetáculo é o resultado de um trabalho coletivo, complexo, contraditório e polêmico”. (PEIXOTO, 2002, p. 182). Em provável menção às dificuldades impostas pelo regime militar e pela censura, comenta que "não existe razão para um encenador permanecer fiel a si mesmo. (...) E em certo sentido o atual momento não é nada propício a opções definitivas. Cada espetáculo é uma experimentação” (PEIXOTO, 2002, p. 182). Ainda sobre a coletivização da criação,

56 PEIXOTO, Fernando. Caderno de Direção. Disponível no Arquivo Fernando Peixoto - CEDOC FUNARTE.

57 Três anos depois de Calabar, em 1976, Peixoto dirigiu um show de Fafá de Belém. Ao descrever a experiência, retomou a importância da música para sua trajetória como diretor até ali: "A música me atraía mais do que nunca: os sambas de Glênio para Pedro Mico, a trilha sonora com muito Billie Holiday e Miles Davis para Poder Negro, canções de Toquinho para Tambores e A Semana, Carlos Castilho para Frei [Caneca], a extraordinária música de Paul Burkhard para Frank V, novamente Toquinho no Grito, Chico e Edu em Calabar, Sidney Miller na Torre [em concurso], Mozart e progressive-jazz no Caminho [de volta] e alguns shows que já havia realizado culminaram em Tamba Tajá”. (PEIXOTO, 1989d, p. 140) 
afirma: "nada mais inteligente do que um diretor, diante de certos casos específicos, limitar-se a organizar e coordenar um espetáculo: não deixa de imprimir sua visão e sua marca pessoal, mas não interfere onde não é necessário interferir” (PEIXOTO, 2002, p. 182).

Especificamente sobre o processo criativo dos atores em Calabar, Peixoto relatou: "A relação de um com o outro era trabalhada em todos os detalhes, quer dizer, se trabalhava igual (...). Não havia para nós diferença entre o chamado “elenco” que faz aqueles personagens todos e a “figuração” digamos, que faz o povo" (PEIXOTO, 2001). A dimensão coletiva e o espaço para a troca de ideias cultivado nos ensaios fazia especial sentido naquele momento histórico. Segundo Imara Reis, atriz da montagem, em entrevista concedida a nós: "Era uma válvula de escape pra ditadura, pra repressão externa. E de repente a gente não tinha mais esse lugar de respiro que eram os ensaios. Que era um lugar extremamente democrático" ${ }^{\text {58. }}$

Do ponto de vista das relações de trabalho, como vimos, Peixoto foi um defensor da viabilidade material do teatro profissional brasileiro. Até mesmo em suas atividades de crítico, costumava considerar as condições materiais de produção como dado importante para compreender uma obra. Em suas notas sobre a encenação no Rio de Janeiro de 1973, comenta o impasse a que Zé Celso chegara: “a inviabilidade, inclusive econômica, do prosseguimento de uma experiência de espetáculo marginal” (PEIXOTO, 2002, p. 186). Em sua preocupação por criar condições profissionais para o teatro brasileiro, inclusive através de políticas públicas para a cultura, em 1985 ingressou no quadro do Instituto Nacional de Artes Cênicas (posteriormente incorporado à Funarte), onde chegou a trabalhar como diretor do Departamento de Teatro.

Em certo sentido, esse posicionamento o diferencia de Amir Haddad, diretor convidado inicialmente para dirigir Calabar. Haddad já havia trabalhado como diretor e ator profissional (foi inclusive um dos fundadores do Teatro Oficina, em que Peixoto posteriormente trabalhou). No entanto, entre 1968 e 1970 optou por um posicionamento diferente, ao participar da experiência do grupo teatral A Comunidade: "Juntamo-nos para constituir um grupo liberto das injunções de um regime empresarial, queríamos o direito de errar sem estarmos sujeitos às leis do lucro, à ditadura das bilheterias" (HADDAD, 1969), disse ele à época em entrevista ao Jornal do Brasil. Havia uma

\footnotetext{
${ }^{58}$ REIS, Imara. Entrevista sobre Calabar. Entrevistadora: Nina Hotimsky. São Paulo, ago. 2016.
} 
recusa à profissionalização, e os espetáculos do grupo A Comunidade eram viabilizados através de uma caixinha mensal com que cada integrante contribuía. Essa recente experiência pode ser relacionada com a demanda por um ano de processo criativo por parte do diretor, quando sondado para encenar Calabar.

Já a organização dos ensaios conduzida por Fernando Peixoto veio ao encontro da expectativa dos dramaturgos de produzir um espetáculo nos moldes profissionais, que tivesse sim viabilidade material através da bilheteria. A experiência do encenador como integrante da direção do Teatro Oficina tornava-o acostumado com esse tipo de preocupação. Essa função o colocava em um lugar de tomada de decisões, não apenas artísticas, mas também administrativas. Como ele próprio afirmava, com seu rigor histórico, o Oficina e o Arena eram “empresas capitalistas com patrões e empregados. O que havia é que a maioria dos patrões era socialista (...). Mas eram empresas capitalistas, não poderia ser de outra forma. Nós éramos patrões”59 (PEIXOTO, 1989b, p. 63). Nos muitos textos que produziu sobre o Teatro Oficina, Peixoto frequentemente lembra a opção por colocar em cartaz uma ou outra peça do repertório como forma de manter o equilíbrio financeiro do empreendimento. Isso sem nunca abrir mão da preocupação com o significado social das produções.

Analogamente, no caso de Calabar, o dinheiro inicial investido precisava retornar. Apenas, como veremos, o volume do aporte era maior do que costumeiramente dispunham os espetáculos politizados do período. Foi esse investimento que possibilitou o pagamento de salários para os trabalhadores envolvidos (atores, músicos, encenador, diretor musical, coreógrafo, cenógrafo, figurinista, iluminador e equipe de produção) desde o período dos ensaios. Em entrevista concedida anos depois o diretor explicitou um impasse frequente do teatro politizado, que diz respeito a Calabar: "Existe uma contradição no espetáculo político que se revela desde séculos (...). Inevitavelmente você precisa de peças com muita gente, porque com peças de três personagens dificilmente você levanta um painel histórico válido”60 (PEIXOTO, 1989b, p. 64). Para

59 Na mesma entrevista, Peixoto também fala sobre um período posterior dos dois grupos em que, após grandes crises econômicas, ambos experimentaram um sistema cooperativo que acabou não dando certo. Segundo ele, no caso do Arena essa tentativa teria sido um recurso para seguir trabalhando. Já no caso do Oficina, teria havido uma tentativa de socialização "Mais radical, e eu diria mais utópica também. Surgiu quando o grupo estava embebido de uma ideologia que se poderia caracterizar como razoavelmente anarquista”. (PEIXOTO, 1989b, p. 64). Nesse momento, em que o Oficina passou a buscar se constituir como comunidade, Peixoto já não trabalhava mais com o grupo.

60 Vale observar que o Sistema Coringa idealizado por Augusto Boal lidava com essa dificuldade. Um de seus objetivos era justamente viabilizar a montagem de espetáculos politizados diversos contando com um número fixo de atores, que se revezariam em diversos papéis. 
que se pagasse toda a equipe para ensaiar, e considerando que se tratava de um elenco numeroso, os ensaios não poderiam durar mais do que três ou quatro meses.

\section{As condições de trabalho}

“Era super bem pago, era bem legal. O Fernando [Torres, produtor] perdeu um dinheirão" ${ }^{61}$. Assim Anselmo Vasconcelos definiu o seu cachê durante os ensaios de Calabar, e as consequências econômicas da censura.

O encenador convidou alguns atores com quem já gostaria de trabalhar; e para constituir o coro, realizou um processo seletivo em três etapas. A atriz Imara descreve: "todo mundo que fazia teatro naquela época, todos os membros de grupo de teatro foram fazer teste!” 62. Ela lembrava-se de ter tomado conhecimento dos testes pelo "boca a boca” - os artistas alertavam os colegas sobre a oportunidade de trabalho. No Arquivo Fernando Peixoto, pudemos verificar que os testes foram também divulgados no jornal. A redação era a seguinte: “Atores e atrizes para Calabar (Chico Buarque Ruy Guerra). Interessados em participar do elenco (qualquer idade, sexo ou cor), com ou sem experiência, disponíveis para ensaios a partir de $1^{\text {a }}$ DE SETEMBRO, sabendo cantar, procurar Fernando Peixoto no TEATRO MAISON DE FRANCE Hoje, 6a feira, a partir das 13 horas”.

Segundo Peixoto (2001), 360 candidatos participaram da primeira fase, uma entrevista. 100 atores passaram para a segunda fase, de canto, sob responsabilidade do diretor musical Dori Caymmi. E 60 atores alcançaram a última etapa, os testes cênicos. Ao final, seriam selecionados quinze homens e doze mulheres. No Arquivo Fernando Peixoto consta uma tabela com o nome de todos os candidatos, e a nota em cada uma das três fases (aparecem as notas A ou B). Ao final da linha, um "S" para sim ou "N" para não, em sua maioria anotados a lápis - o próprio diretor relatou em entrevista o “medo de estar errado na escolha” (PEIXOTO, 2001).

Constituída a equipe, iniciou-se uma rotina intensa de trabalho. Imara Reis lembrou que os ensaios ocorriam diariamente e duravam cerca de oito horas, e acrescentou:

61 VASCONCELOS, Anselmo. Entrevista sobre Calabar. Entrevistadora: Nina Hotimsky. São Paulo, jul. 2017.

62 REIS, Imara. Entrevista sobre Calabar. Entrevistadora: Nina Hotimsky. São Paulo, ago. 2016. 
Era todo mundo carteira assinada. (...) Até oitenta e pouco, teatro tinha carteira assinada. Contrato de trabalho como qualquer outro. A gente era trabalhador. Isso dava compromisso profissional que agora você não tem. Mandar embora uma pessoa que tem carteira assinada implica algumas responsabilidades trabalhistas, um mínimo de segurança. Tanto é que todo mundo abriu mão, ninguém acionou o Fernando [Torres]. Entendeu? A gente ficou assim! Não só a gente perdeu um grande espetáculo, como a gente perdeu o emprego. Desemprego coletivo, pra essa curiola imensa! ${ }^{63}$.

Os dois atores entrevistados manifestaram preocupação com a pessoa do produtor. Fernando Torres também era artista, estava próximo daquele universo - não era um produtor distante de uma grande corporação do entretenimento. O diretor musical Dori Caymmi elogiou: "Não era uma grana enorme, mas o trabalho do Fernando Torres como produtor foi muito bom. Eu tinha trabalhado com alguns caras profissionais no Teatro Casa Grande, Kilomax. Mas o Fernando eu gostava e respeitava muito" 64 .

É curioso que tenha vindo de Dori o parênteses “não era uma grana enorme”. A experiência anterior de Dori com Torres havia se dado na televisão (ele fazia as trilhas para o grupo Teatro dos Sete na TV Tupi). É provável que a televisão pagasse à época salários maiores do que os do teatro. Dori também fala do lugar de músico; um músico que trabalhou com teatro desde cedo, e integrou parte importante dos musicais politizados das décadas de 1960 e 1970. Entre outros trabalhos, Dori realizou a direção musical do Show Opinião (1965), de Arena conta Zumbi em sua versão carioca (1966), de Calabar e também de Gota d’Água (1975). Quando perguntado a respeito do Centro Popular de Cultura (CPC) como antecedente do grupo Opinião, Dori afirmou: "Eu não tinha esse envolvimento, por não fazer parte de grupo de estudantes. Foi uma coisa muito ligada à faculdade (...). O meu negócio foi todo relacionado com trabalho. Era

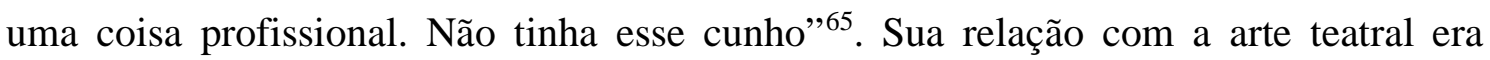
profissional, e não advinda de uma militância. Essa ótica fazia-o enxergar os impasses econômicos do teatro com algum distanciamento:

O negócio do teatro é que normalmente, são pessoas muito corajosas porque trabalham muito sem recurso. E há muito tempo é assim sem recurso. E dava pena de ver o desgaste da pessoa, e por uma causa linda mas pô! Dava um trabalho desgraçado e era muito pouco remunerada. No caso do show Opinião mesmo, foi feito um mutirão, limpou-se um lugar que estava sujo, com restos

63 REIS, Imara. Entrevista sobre Calabar. Entrevistadora: Nina Hotimsky. São Paulo, ago. 2016.

${ }^{64}$ CAYMMI, Dori. Entrevista sobre Calabar. Entrevistadora: Nina Hotimsky. Rio de Janeiro, jan. 2018.

${ }^{65}$ CAYMMI, Dori. Entrevista sobre Calabar. Entrevistadora: Nina Hotimsky. Rio de Janeiro, jan. 2018. 
de madeira, e a gente ajudava. Eu carreguei cadeira... foi muito complicado no princípio o Opinião, porque não tinha recurso ${ }^{66}$.

O processo de Calabar foi bastante diferente: “O Fernando Torres era um cara organizado. Muito mais organizado do que foi o Opinião”67. Houve recursos investidos desde o início do trabalho. A censura de Calabar quase levou a empresa Fernando Torres Diversões à falência. Fernanda Montenegro, esposa de Fernando Torres e sócia na produtora, relatou em entrevista recente ao jornal O Globo que foram salvos pela “montagem de $\mathrm{O}$ amante de madame Vidal, cujo sucesso pagou as dívidas. Mas o desespero após a censura foi tanto, pelo prejuízo e pelo medo de uma retaliação mais violenta, que sequer guardamos a documentação da peça"68. O encerramento da produção também prejudicou enormemente todos os artistas envolvidos, que já contavam com salário por mais alguns meses.

Renato Laforet, assistente de produção, acrescentou mais um dado em sua entrevista: mesmo antes da estreia, já se preparava uma circulação nacional do espetáculo. Ele estava responsável por organizar as viagens por diversas cidades de todo o Brasil. Segundo ele, a previsão era de que após a temporada carioca Calabar viajaria em turnê por aproximadamente um ano (tempo em que os contratos de trabalho de toda a equipe estariam garantidos).

Renato também era o responsável pela produção da cenografia e figurino. A "forma sofisticada de censura" - como definiu a censura econômica - lhe revolta pela lembrança dos gastos já realizados, para além do pagamento de salários. Ele descreveu, a título de exemplo, o trabalho e o alto custo envolvido na realização dos figurinos de época: “As botas eram de couro, feitas sob medida, e iam até os joelhos!” 69.

Após o cancelamento da estreia, Laforet teve uma tarefa ingrata: devolver o dinheiro dos ingressos que já tinham sido vendidos ${ }^{70}$. Segundo ele, a primeira semana já estava lotada ("os mil e quatrocentos ingressos vendidos!" ${ }^{71}$ ), e havia 15 dias de

\footnotetext{
${ }^{66}$ CAYMMI, Dori. Entrevista sobre Calabar. Entrevistadora: Nina Hotimsky. Rio de Janeiro, jan. 2018.

${ }^{67}$ CAYMMI, Dori. Entrevista sobre Calabar. Entrevistadora: Nina Hotimsky. Rio de Janeiro, jan. 2018.

${ }^{68}$ FONSECA, Rodrigo. Marco da censura no Brasil, Calabar faz 40 anos com nova montagem. O Globo, Rio de Janeiro, 12 mai. 2013. Disponível em: $<$ https://oglobo.globo.com/cultura/marco-da-censura-nobrasil-calabar-faz-40-anos-com-nova-montagem-8363246\#ixzz5APDj6egs>. Acesso em: abr. 2019.

69 LAFORET, Renato. Entrevista sobre Calabar. Entrevistadora: Nina Hotimsky. São Paulo, ago. 2016.

${ }^{70}$ Consta no anexo C dessa dissertação (Figura 17) um documento do DCE da PUC que informa os estudantes sobre a devolução do dinheiro de ingressos já comprados para assistir Calabar.
}

71 LAFORET, Renato. Entrevista sobre Calabar. Entrevistadora: Nina Hotimsky. São Paulo, ago. 2016. 
reservas previamente realizadas. A possibilidade de retorno financeiro via bilheteria era real.

\section{$\underline{\text { O investimento perdido }}$}

A censura econômica causou grandes prejuízos: de acordo com Tânia Pacheco, “Calabar situava-se entre as produções mais caras do país, com investimento de 400 mil cruzeiros na época” (PACHECO, 1979, p. 96). Este mesmo valor é mencionado pelo crítico teatral Yan Michalski em seu livro “O palco amordaçado”. Segundo o conversor de valores da página Acervo Estadão, este valor significaria hoje 2 milhões de Reais $^{72}$.

Em outras fontes, encontramos valores diferentes. Segundo a historiadora Vavy Pacheco: “Nos arquivos do DOPS, a produção de Fernando Torres Diversões dá como orçamento total da peça 290.750,40 cruzeiros” (BORGES, 2017, p. 236). Cacá Teixeira, Diretor de Produção de Calabar, afirmou em entrevista ${ }^{73}$ que o gasto foi de 300 mil Reais (talvez querendo dizer 300 mil cruzeiros, o que aproximaria o dado ao valor declarado no DOPS). No site oficial de Chico Buarque, temos o valor estimado em dólares: $30 \mathrm{mil}^{74}$.

Apesar das mudanças na moeda brasileira e das oscilações do câmbio, é consenso que Calabar foi um grande investimento. O ator Anselmo Vasconcelos, que participou do processo criativo, afirmou em entrevista:

Anselmo - Esse espetáculo era um produto comercial top de linha.
[Risos]. Então ele tinha todas as características disso. Era o principal
compositor, a estrela da televisão, Betty Faria, a estrela da cenografia
e da caracterização que era o Helio Eichbauer, a estrela dos arranjos
musicais que era o Dori Caymmi e o Edu Lobo, e a estrela do cinema,
da dramaturgia brasileira que era o Ruy Guerra. E a estrela da direção
que era o Fernando Peixoto. Então era um espetáculo top.
Nina - Mas era um espetáculo top que queria dizer coisas ainda, não
é? Não era uma mercadoria vazia?
Anselmo - Porque só se fazia teatro pra se dizer coisas. Não havia
escapismo (...). Eu acho que foi um banho de loja da esquerda. A
esquerda tomou um banho de loja, fez um espetáculo... "Uau!”.
Vistoso, caro. Porque os espetáculos de esquerda eram pobres. Era

72 CONVERSOR de valores. Disponível em: <http://acervo.estadao.com.br/>. Acesso em: dez. 2017.

73 CHAVES, Carlos Alberto Teixeira. Entrevista sobre Calabar. Entrevistadora: Nina Hotimsky. São Paulo, ago. 2017.

74 Segundo o site de Chico Buarque. http://chicobuarque.com.br/construcao/index.html Acesso em: nov. 2017. 
Boal, era Zé Renato, aquelas roupas, todo mundo com a mesma roupa. Não tinha figurino, não tinha nada. “Arena conta” né?75

Durante a entrevista, Anselmo fez questão de não romantizar a pobreza de um espetáculo. Mencionou outras produções da época, como O Balcão e Cemitério de Automóveis, que precisaram de produções mais caras para alcançar suas propostas estéticas. Claro que uma peça que depende de financiamentos mais altos gera problemas específicos, a saber: como conseguir o investimento inicial? O retorno se dará através de ingressos? $\mathrm{O}$ valor dos ingressos pode realizar um recorte de classe, selecionando apenas espectadores com mais recursos?

No caso de Calabar, segundo o diretor de produção Cacá Teixeira relatou em entrevista, o investimento inicial veio de três fontes: "A Philips entrou com 100 mil, Chico Buarque com 100 mil e Fernando Torres Diversões com outros 100 mil” ${ }^{76}$. Que o autor da peça investisse parte do dinheiro era prática comum - Chico Buarque já havia financiado sua peça anterior, Roda Viva, em 1968. Chico e Ruy Guerra iriam investir a mesma quantia de dinheiro, mas Ruy estava em dificuldades financeiras à época, e acabou devendo a Chico sua parte. Em entrevista, contou que a dívida acabou sendo perdoada pelo parceiro ${ }^{77}$. Chico já gozava de alguma estabilidade, conquistada por seu trabalho musical.

Outro terço do orçamento veio da empresa Fernando Torres Diversões, de Fernando Torres e Fernanda Montenegro. Um espetáculo daquele porte demandava um esforço grande de produção, e a empresa, além de contribuir financeiramente, acompanhou os trabalhos com sua equipe especializada. Na ficha técnica constam três trabalhadores dessa área: o próprio Cacá Teixeira, e seus assistentes de produção Renato Laforet (também entrevistado por nós) e Leda Borges.

A terceira parte do investimento é que faz de Calabar um caso particular. Como a multinacional Philips veio a investir em um espetáculo de caráter político? Cacá Teixeira fez questão de lembrar que, naquela época, não existiam mecanismos de incentivo fiscal (sistema em que uma empresa transfere valores de impostos que já teria de pagar para uma produção cultural de sua escolha). Que um terço dos recursos do espetáculo tenham vindo da gravadora de Chico Buarque impõe que estudemos

75 VASCONCELOS, Anselmo. Entrevista sobre Calabar. Entrevistadora: Nina Hotimsky. São Paulo, jul. 2017.

76 CHAVES, Carlos Alberto Teixeira. Entrevista sobre Calabar. Entrevistadora: Nina Hotimsky. São Paulo, ago. 2017.

77 GUERRA, Ruy. Entrevista sobre Calabar. Entrevistadora: Nina Hotimsky. São Paulo, mar. 2018. 
brevemente a situação da indústria fonográfica no Brasil à época. Calabar também precisa ser visto, no que se refere aos aspectos produtivos, como um caso de aliança direta entre teatro musical politizado e mercado musical brasileiro em ascensão. Não fosse a censura, essa aliança teria sido a responsável por viabilizar um espetáculo de grandes proporções.

Do ponto de vista material, aquele era um momento em que a Indústria Fonográfica no Brasil prosperava - favorecida pelo modelo de modernização conservadora instalado pela Ditadura Civil-Militar. Margarida Autran descreve a indústria fonográfica como "a mais multinacional entre as indústrias brasileiras”; seu crescimento durante a década de 1970 foi de em média 15\% ao ano (AUTRAN, 1979, p. 94). Havia recursos em caixa e boas razões para investir em Chico Buarque, artista que já fazia sucesso ${ }^{78}$. O interesse da empresa por Calabar foi conquistado pela amplitude do projeto: Teixeira lembrou-se do chavão "leia o livro, escute o disco e veja a peça"79. O disco, é claro, seria gravado pela Philips ${ }^{80}$.

Além do investimento financeiro na peça, a Philips encarregou-se da produção do playback que seria utilizado em cena. Um texto sobre Calabar publicado na revista francesa Travail Théâtral esclarece: “A parte sonora misturava um conjunto de músicos tocando ao vivo e uma fita gravada com orquestra nos estúdios da Philips do Brasil”81. Aquele momento de grande lucratividade para as gravadoras permitia a produção de áudios com muitos timbres, a contratação de diversos instrumentistas - ao menos quando se tratava de Long Plays dos artistas de prestígio. Esse recurso veio ao encontro das necessidades de Edu Lobo, responsável pela orquestração do espetáculo e do disco, conhecido por seus arranjos complexos. Tudo indica que a mesma gravação, que

78 Chico Buarque tematizou a relação entre o cantor e a sua gravadora na bem-humorada canção “A voz do dono e o dono da voz”, do álbum Almanaque (1981). A letra narra a trajetória de um artista (a voz) que muda de gravadora (o dono da voz), indo "morar com novo algoz”. Afinal, sempre precisaria veicular seu trabalho - à época através de discos de vinil: "Queria se prensar, queria ser um prato / Girar e se esquecer veloz”. E embora as notas entoadas fossem suas, o artista não possuía os meios de produção para fazer seu trabalho circular: "Deus deu ao dono os dentes, Deus deu ao dono as nozes / Às vozes Deus só deu seu dó”. Em última instância, as liberdades do cantor seriam determinadas pelas necessidades de seu empresário: "o que é bom para o dono [a gravadora] é bom para a voz".

79 CHAVES, Carlos Alberto Teixeira. Entrevista sobre Calabar. Entrevistadora: Nina Hotimsky. São Paulo, ago. 2017.

80 O Prof. Dr. Walter Garcia, na banca de qualificação deste mestrado, sugeriu a possibilidade de que a parte de investimento cedida pela Philips ao espetáculo fosse uma espécie de adiantamento dos ganhos que Chico Buarque receberia com a venda do LP. A pesquisa ainda não permitiu uma averiguação da hipótese, que é de todo o modo bastante interessante. Agradeço ao professor pela sugestão.

${ }^{81}$ CALABAR interdit - tradução do texto publicado em "Travail Théâtral”. Travail Théâtral, Paris, primavera, 1974. Disponível em: <http://chicobuarque.com.br/critica/crit_calabar_travail.htm>. Acesso em: mar. 2019. 
envolveu “dezenas de músicos” (PEIXOTO, 1989c, p. 159) ${ }^{82}$, foi utilizada posteriormente no disco de Chico Buarque. Ou seja: o investimento necessário para gravar um disco de alta qualidade seria aproveitado para permitir arranjos grandiosos já nas apresentações da peça teatral. Isso torna o caso de Calabar diferente de outros espetáculos que se tornaram LPs, em que a trilha foi gravada já após o sucesso de uma peça. Nesse ponto a parceria com a gravadora influenciou as opções estéticas da peça. Dentre as direções de Fernando Peixoto até então, Calabar foi talvez a obra de efeito sonoro mais espetacular.

À época de Calabar o marketing experimentava novas estratégias. No contexto da indústria fonográfica, os gestores observavam que a empatia entre o cantor e o público era essencial para as vendas de discos. Canções tecnicamente simples, vozes desafinadas, podiam fazer um grande sucesso quando se comunicavam com questões que a população enfrentava no dia-a-dia. Midani, empresário da Philips, menciona como exemplo em sua autobiografia o cantor Orlando Dias, que era porta-voz "do inconsciente coletivo do povo nordestino emigrado do sertão para as cidades” (MIDANI, 2008, p. 85). Orlando vendeu mais de cinquenta mil cópias de seu primeiro disco, e o fez de maneira espontânea, sem que a gravadora investisse em sua promoção.

Segundo Midani, esse tipo de fenômeno passou a ser analisado e manipulado pelas empresas. Psicólogos e psicanalistas passaram a fazer parte da equipe responsável por divulgar os produtos da Philips:

\footnotetext{
"meus psicanalistas e eu nos encontramos diversas vezes com alegria e crescente entusiasmo, conscientes das possibilidades que se abriam diante de nós por meio desse novo brinquedo de poder (...). A gente quis também comprovar se era possível orientar de maneira mais adequada e certeira a imagem do artista perante o público. Estava para nascer o marketing psicanalítico!!!!” (MIDANI, 2008, p. 87).
}

É certo que isso não se deu apenas no contexto da indústria fonográfica estratégias semelhantes eram adotadas para vender todo o tipo de mercadoria. Dentre as experiências publicitárias feitas pela Philips à época, Midani menciona artistas que construíram suas imagens apelando para religiosidade, casos amorosos, aparência física,

\footnotetext{
${ }^{82}$ Marcus Vinicius, diretor musical do Calabar de 1980 (que criou arranjos diferentes para canções já conhecidas) estimou que os playbacks de 1973 contariam com quarenta músicos. Em texto publicado no programa do espetáculo, afirmou que sua concepção seria "mais teatral e despojada. Em vez de quarenta músicos, seis”.
} 
naturalidade, opção política, entre outros fatores. Tudo em diálogo com o público alvo pretendido.

O empresário narra diversos episódios em que a resistência de artistas à ditadura foi trabalhada para promovê-los. Um exemplo: em 1969, durante sua prisão domiciliar e logo antes de ser exilado, Gilberto Gil compôs a canção de despedida “Aquele Abraço”. Sua gravação foi feita em sigilo, durante uma noite de sexta para sábado, nos estúdios da Philips. Sábado de manhã foram produzidas diversas cópias em fita, imediatamente distribuídas para rádios do Rio de Janeiro e de São Paulo. Midani conta: "Fui acompanhar os meninos [Caetano e Gil] até o Aeroporto do Galeão (...). Voltei para casa com o rádio ligado e “Aquele abraço” estava tocando em muitas estações antes mesmo de o avião decolar” (MIDANI, 2008, p. 87).

O episódio ao mesmo tempo emociona por sua força crítica, e nos interessa na medida em que contribuiu para os negócios. Ele expressa o que Marcos Napolitano descreveu como a

condição paradoxal da música popular brasileira naquela década marcada pelo autoritarismo: foco de resistência e da identidade cultural de uma oposição civil ao regime militar, as canções rotuladas como parte da "MPB - Música Popular Brasileira" eram extremamente valorizadas pela indústria fonográfica brasileira (NAPOLITANO, 2010, p. 389).

As motivações políticas e os interesses econômicos faziam parte de um mesmo fenômeno. E as contradições se expressavam também no comportamento das gravadoras. Em uma época em que diversos artistas eram perseguidos, a Philips assumiu uma "responsabilidade moral, artística e financeira” (MIDANI, 2008, p. 118) com os exilados. A empresa "se comportaria como a multinacional que de fato era e utilizaria todos os meios à sua disposição em outros países para esses artistas seguirem suas carreiras” (MIDANI, 2008, p. 118). Foi aliás esse recurso que trouxe Chico Buarque da gravadora independente RGE para a Philips, durante seu exílio em Roma em 1970. Através de uma complexa operação internacional, com gravações feitas na Itália e no Brasil, a Philips lançou o disco Chico Buarque de Hollanda $n^{\circ} 4$. Midani afirma que essa estratégia foi "um ato moderno e um fato novo no comportamento da indústria fonográfica brasileira. O lançamento teve um efeito fulminante, ainda mais pelo excesso de timidez das outras gravadoras na relação com Brasília” (MIDANI, 2008, p. 120). Por “efeito fulminante" entendemos que houve um bom retorno 
financeiro para a gravadora. Claro que a falta de timidez de uma multinacional em relação aos governantes brasileiros pode ser relacionada com o seu poder econômico e sua independência em relação ao Brasil.

No caso de Calabar, traçou-se em parceria com a Philips o plano de aproveitar um espetáculo teatral de sucesso para promover o disco do já célebre Chico Buarque. Podemos aninhar a estratégia às novas experiências publicitárias então em curso. Não seria a primeira vez que se associaria uma peça teatral a um Long Play. Especificamente no contexto das peças de teatro musical politizado produzidas após o golpe, Morte e Vida Severina (1965, com músicas de Chico Buarque para o texto de João Cabral de Melo Neto), Opinião (1965), Arena conta Zumbi (1965), Liberdade Liberdade (1965), entre outros, geraram discos. Em Liberdade Liberdade a relação de uma gravadora com a peça foi além do simples registro das canções: organizou-se um concurso de sambas com o tema da liberdade. O modelo competitivo era claramente inspirado nos Festivais de Música Popular Brasileira então em voga. A promessa impressa no programa do espetáculo é de que os quatro sambas vencedores seriam gravados por Nara Leão, com selo da Philips ${ }^{83}$.

Infelizmente, no caso de Calabar, a censura do espetáculo estendeu-se para o uso do título da peça em quaisquer outros meios, e o LP, que seria chamado de Chico Canta Calabar ${ }^{84}$, foi lançado com o nome Chico Canta. Sem o título original, com letras inteiras censuradas e até a arte da capa proibida (originalmente o nome "Calabar" aparecia pichado em um muro, à semelhança de frequentes mensagens de protesto contra a ditadura), o LP fez muito menos sucesso que os demais álbuns de Chico Buarque $^{85}$. É por isso que o historiador Marcos Napolitano vê o fracasso do disco Chico

\footnotetext{
${ }^{83}$ Essa ação da Philips foi realizada independentemente da gravação da trilha do espetáculo (que foi lançada por outra empresa, a gravadora Forma, em 1966). Ao final, apenas uma das canções vencedoras do concurso foi gravada, "Manhã de Liberdade", de Nelson Lins de Barros. O disco, que foi lançado com o mesmo título Manhã de Liberdade (1966), incluiu também três canções de autoria de Chico Buarque. A história desse espetáculo e de seus subprodutos culturais é descrita por Natália Batista em seu livro. BATISTA, Natália. Nos palcos da história: teatro, política e Liberdade Liberdade. São Paulo: Letra e voz, 2017.

84 Este título também seria uma menção irônica ao CCC, Comando de Caça aos Comunistas, que invadiu o espetáculo anterior de Chico Buarque (Roda Viva) e agrediu atores.

85 Seu disco solo imediatamente anterior (Construção, de 1971) "nas primeiras semanas de lançamento, atingiu a venda de 140 mil cópias, índice comparável aos de Roberto Carlos e Martinho da Vila”. NAPOLITANO, Marcos. A música popular brasileira (MPB) dos anos 70: resistência política e consumo cultural. Actas del V Congresso Latinoamericano IASPM, 2002. RL:http://www.educadores.diaadia.pr.gov.br/arquivos/File/fevereiro2012/historia_artigos/2napolitano70_ artigo.pdf. Acesso em 2 abr. 2018. Página 5.
} 
Canta como uma "demonstração dramática do poder da censura sobre o mercado musical” (NAPOLITANO, 2002, p. 5).

É preciso observar que esse tipo de prejuízo estava previsto no cotidiano da empresa Philips. Vale incluir um dado pessoal: quem autorizou o financiamento da peça foi André Midani. O mesmo empresário que conseguiu documentos holandeses a respeito do Domingos Fernandes Calabar histórico para os autores, e que trouxe Chico Buarque para a Philips. Em sua autobiografia, ele confirma que "concordou em financiar parte da peça” Calabar (MIDANI, 2008, p.122), e revela diversos casos diferentes em que obteve prejuízos ao produzir obras importantes. Claro que quando um setor artisticamente consequente gerava perdas, outros setores precisavam garantir o lucro. Para gerenciar essa equação, as gravadoras criavam selos internos destinados à “faixas de prestígio" e outros dedicados à "faixas comerciais”. Essa dinâmica da indústria fonográfica da época, já analisada por Marcos Napolitano (2002), não caberá nos limites deste texto.

Se o prejuízo foi aceitável para a Philips, certamente não o foi para os dramaturgos, produtores, elenco e equipe contratados. Ao menos três espetáculos foram responsáveis pela recuperação financeira de parte dos envolvidos: as peças $O$ amante de Madame Vidal (1973) e A torre em concurso (1974), e o show Tempo e Contratempo (1974). Esses três empreendimentos chamam a atenção por envolver mais de um integrante da ficha técnica de Calabar. A censura produziu (nas palavras de Imara) um “desemprego coletivo”; as saídas para a crise também foram parcialmente coletivas.

Fato é que algumas das contradições vividas por Calabar como uma superprodução se assemelham às encaradas pela MPB na mesma época:

Os dilemas e contradições da canção em geral, e da MPB em particular, expressam os dilemas e contradições dessa mesma resistência civil no seio da classe média brasileira, mais afeita à tradição radical do que aos impulsos revolucionários (CANDIDO, 1990) ${ }^{86}$. Esses dilemas poderiam ser traduzidos em equações de difícil resolução normativa: Como manter a "boa palavra" circulando em tempos sombrios? Como ampliar o leque de interlocutores e correligionários do campo estético-ideológico? Como conciliar as

\footnotetext{
${ }^{86}$ Napolitano faz referência ao texto Radicalismos, de Antonio Candido. Trata-se de um estudo da noção de "radicalismo" no Brasil: "Gerado na classe média e em setores esclarecidos das classes dominantes, ele não é um pensamento revolucionário, e, embora seja fermento transformador, não se identifica senão em parte com os interesses específicos das classes trabalhadoras, que são o segmento potencialmente revolucionário da sociedade” (CANDIDO, 1990, p. 4). Segundo essa análise, diversos artistas e intelectuais de esquerda (inclusive os que trabalharam em Calabar) tenderiam ao radicalismo, mais do que a uma atitude revolucionária.
} 
benesses da modernização e do acesso ao mercado com a atitude crítica às políticas do governo autoritário? Como falar às classes populares, vistas como sujeitos da história pela cultura de esquerda que lastreava a MPB, sem os códigos e canais apropriados? (NAPOLITANO, 2010, p. 390-1).

Todas essas perguntas são pertinentes para discutir Calabar. E especialmente a terceira delas (como conciliar acesso ao mercado e atitude crítica) faz da montagem um caso raro. Artistas teatrais da classe média de esquerda frequentemente se perguntaram sobre a circulação de suas obras. Augusto Boal afirmou em 1968 que a exortação da luta política no teatro “só tem validade no convívio popular” (BOAL, 2016, p. 29). Ele retomava a crítica feita por Vianinha ${ }^{87}$ e Chico de Assis anos antes, por ocasião de seu rompimento com o Arena (que culminou na fundação do CPC, em 1961). Boal questionava a apresentação de peças como Arena conta Zumbi no pequeno espaço do Teatro de Arena, para cerca de cento e cinquenta espectadores, também de classe média. Ele vislumbrava o teatro feito nas praças, para o povo; poucos anos depois se dedicou ao desenvolvimento do Teatro do Oprimido.

Mas Calabar não ficaria em cartaz no Teatro de Arena, e sim no Teatro João Caetano, de mil e trezentos lugares. Não por coincidência, esse foi um dos teatros que se “consagraram como verdadeiros 'templos da MPB'” (NAPOLITANO, 2010, p. 398). Artistas celebrizados pelos festivais da canção, divulgados pela televisão e pelo rádio, gravados pela indústria fonográfica e por ela massivamente distribuídos, faziam ali seus shows. Esse dado não resolve as contradições que Calabar teria enfrentado caso houvesse estreado, mas faz parte das questões específicas que o projeto mobilizava. Não

\footnotetext{
${ }^{87}$ Em seu texto "Do Arena ao CPC", publicado na Revista Movimento da União Nacional de Estudantes (UNE), $n^{\circ}$ 6, out. de 1962, Vianinha afirmara: "O Arena era porta-voz das massas populares num teatro de cento e cinquenta lugares... O Arena não atingia o público popular e, o que é talvez mais importante, não podia mobilizar um grande número de ativistas para o seu trabalho. A urgência de conscientização, a possibilidade de arregimentação da intelectualidade, dos estudantes, do próprio povo, a quantidade de público existente, estavam em forte descompasso com o Teatro de Arena enquanto empresa. Não que o Arena tenha fechado seu movimento em si mesmo; houve um raio de ação comprido e fecundo que foi atingido com excursões, com conferências etc. Mas a mobilização nunca foi muito alta, porque não podia ser muito alta. E um movimento de massas só pode ser feito com eficácia se tem como perspectiva inicial a sua massificação, sua industrialização. É preciso produzir conscientização em massa, em escala industrial. Só assim é possível fazer frente ao poder econômico que produz alienação em massa. O Teatro de Arena, esbarrando aí, não teve capacidade, naquele movimento, de superar esse antagonismo. O Arena contentou-se com a produção de cultura popular, não colocou diante de si a responsabilidade de divulgação e massificação. Isto sem dúvida repercutia em seu repertório, fazendo surgir um teatro que denuncia os vícios do capitalismo mas que não denuncia o capitalismo ele mesmo. O Arena, sem contato com as camadas revolucionárias de nossa sociedade, não chegou a armar um teatro de ação, armou um teatro inconformado" (VIANNA Filho apud BIO, 2013, p. 126).
} 
foram frequentes os momentos em que peças teatrais de esquerda tiveram esse tipo de acesso às “benesses da modernização”.

\section{Fernando Peixoto e a forma de produção de Calabar}

Em texto destinado ao programa do espetáculo, Peixoto afirmou: “o aparato de superprodução não é um fim em si, define uma opção instrumental para sondar uma verdade difícil. O teatro procura erguer sua voz dentro da sociedade brasileira” (PEIXOTO, 1989c, p. 157). O gesto de falar sobre a forma de produção em um texto que seria lido pelos espectadores mostra que o encenador estava atento às contradições inerentes ao processo, e disposto a dialogar sobre elas. Ao mesmo tempo, lhe interessava verificar se aquele aparato poderia contribuir para que o teatro brasileiro fosse escutado, reverberasse na sociedade.

Peixoto produziu diversos questionamentos sobre a forma de produção de Calabar: o tempo reservado para a criação, o volume de investimento, o envolvimento de pessoas famosas. Sua preocupação dizia respeito ao efeito que esses dados materiais teriam no resultado artístico, e ficou registrada especialmente na fita que ele gravou sozinho no dia 18 de novembro de 1973. Naquele momento a censura já havia impedido a estreia da peça. Peixoto sabia que estava avaliando um processo não concluído, mas se perguntava: teria sido possível ir mais fundo em seus debates e pesquisas de linguagem?

Logo no início da fita o encenador levanta o problema do tempo que fora disponibilizado para o trabalho. Diz que a montagem havia sido preparada "às pressas, pouco tempo de ensaio”. Vimos que Amir Haddad, o outro encenador sondado pelos dramaturgos, pedira um ano de trabalho para montar o mesmo texto. Os ensaios de Calabar começaram em setembro de 1973, e a estreia estava prevista para 8 de novembro. A rapidez do processo se tornaria um problema, na visão do encenador, na

medida em que "teria resultado numa simplificação, num esquematismo de muitos momentos" (1973c).

No contexto do teatro profissional da época, era comum que peças fossem criadas em poucas semanas. Isso viabilizava o pagamento dos atores já na fase dos ensaios. Mas Peixoto estava habituado a trabalhar com companhias de elenco razoavelmente estável, como era o caso do Teatro Oficina, do Arena e de suas direções no Teatro São Pedro. Um grupo que estuda e ensaia junto seguidamente tende a criar 
uma afinação, uma linguagem comum que é colocada em movimento em cada nova criação. Há um repertório de recursos conhecidos por todos de que se pode lançar mão.

Além de recursos e de uma linguagem comuns, as companhias de teatro politizado daquela época aprofundavam um debate sobre o significado de suas peças. Tanto no Oficina como no Teatro São Pedro os textos a serem montados eram escolhidos em função da pertinência dos debates veiculados. Em ambos os espaços Peixoto participou do grupo que tomava essa decisão: no primeiro como membro da equipe de direção e no segundo como participante da comissão de discussão de repertório. Mesmo os atores não envolvidos nessa tomada de decisão deveriam compreender os critérios utilizados na escolha. Já sobre Calabar, Peixoto descreve um trabalho

com uma equipe de qualidade mas ao mesmo tempo não totalmente identificada até o fim numa mesma visão das coisas. Talvez a equipe que produziu o espetáculo não tenha pesquisado entre si, discutido entre si até suas últimas consequências o verdadeiro significado da montagem Calabar como obra de arte (1973c).

Em um momento de repressão violenta, após a tortura e o exílio de parceiros teatrais próximos como Augusto Boal e Zé Celso, incomodava a Peixoto montar um espetáculo sem que houvesse uma reflexão coletiva sobre o seu sentido. Subjaz à afirmação o receio de que o espetáculo fosse tomado pela equipe como um mero emprego provisório, quando para Peixoto o teatro profissional era também um lugar de expressão política. Para ele, o acordo da equipe sobre o significado da obra produziria marcas na peça, que por sua vez gerariam efeitos na recepção da mesma pelos espectadores.

O encenador sabia que estava em um contexto produtivo diferente daquele vivenciado no Arena, no Oficina ou no São Pedro (mesmo considerando as diferenças entre cada um desses agrupamentos). Não havia uma ingenuidade a respeito do projeto: ele afirma que “a própria proposta talvez me colocasse numa certa crise”, pois via-se “montando Calabar dentro de circunstâncias muito difíceis e particulares, e preso a toda uma série de ingerências de ordem institucional e profissional em certo sentido da palavra” (1973c). Seu incômodo era detectar a influência da forma de produção no resultado teatral que se desenhava: 
O espetáculo foi castrado mesmo. Mas será que no momento em que foi castrado, ele não poderia já ter atingido um nível maior? E (...) até que ponto se deve a uma incapacidade de realizar o que eu penso, ou até que ponto se deve às condições empresariais em que ele foi encenado, ou até que ponto se deve à presença de milhões de milhares de cruzeiros sendo gastos e às datas limites para ensaio, para apresentação pública. Até que ponto se deve ao fato de eu estar trabalhando com gente conhecida, até que ponto se deve a uma não integração total entre a equipe num nível de uma discussão de princípios (1973c).

Nesse trecho, além de retomar o pouco tempo para ensaio e a falta de integração total da equipe, Peixoto menciona outros dois aspectos produtivos: o volume dos investimentos e a fama de alguns dos artistas envolvidos. A questão dos gastos aparece em outros pontos do depoimento quando o encenador se refere a Calabar como uma “superprodução”, e afirma que “a presença do dinheiro por trás traz uma certa limitação”, por depender “dos horários, das datas, dos limites de tempo de ensaio, do grande número de pessoas reunidas” (1973c).

É interessante observar o uso do termo "limitação": ele aparece mais frequentemente em contextos em que há pouco dinheiro, e não dinheiro demais. Nesse caso, Peixoto sentia que o investimento limitava o tempo dos ensaios (já vimos que era preciso estrear rapidamente para que a bilheteria cobrisse os gastos), e também o aprofundamento na pesquisa de linguagem. O encenador descrevia a montagem como “complexa”: ela lhe solicitava o refinamento na direção de 37 atores, das coreografias, das intervenções musicais. Era preciso harmonizar a execução dos cinco músicos que tocariam ao vivo com o playback gravado por outros 40 instrumentistas. Paradoxalmente, o investimento lhe oferecia recursos artísticos múltiplos, mas não um contexto que permitisse uma experimentação profunda com esses recursos.

A presença de "gente conhecida” fazia parte do problema. Por um lado, Calabar é um momento raro do teatro brasileiro inserido no circuito comercial. Ali se reuniu uma equipe formada por artistas magistrais, com interesse em produzir um debate político consequente; como Anselmo resumiu, foi um “banho de loja da esquerda”. Por outro lado, há uma espécie de responsabilidade de ordem mercantil envolvida em lidar com nomes de sucesso. Chico Buarque, por exemplo, já fora envolvido em certo escândalo por ocasião da montagem de Roda Viva, em $1968^{88}$. Já vimos que a Philips

\footnotetext{
${ }^{88}$ A encenação de Roda Viva por Zé Celso foi moralmente chocante e abalou a imagem de Chico Buarque como um "bom moço" que a mídia alimentava. A tendência de certa crítica especializada foi contrapor dramaturgia e encenação, como se o texto inicial houvesse sido completamente transformado
} 
estava acostumada a lucrar com produções de esquerda; também o teatro politizado experimentara bons resultados de bilheteria em diversas ocasiões ${ }^{89}$. Mas um experimentalismo radical poderia dificultar a lotação de um teatro de mil e trezentos lugares, e a boa venda dos discos de Chico.

Anos depois, em depoimento a Yan Michálski por ocasião da estreia do Calabar de 1980, Peixoto voltou a chamar a montagem de 1973 de superprodução, mas abordou esse tema sob outro olhar: "Esta visão tinha uma função para a época, quando o teatro estava sendo esmagado, reduzido a dramas intimistas de dois ou três personagens, e quanto à tentativa de devolver-lhe o caráter de teatralidade tinha nítida importância” 90 . Se durante a criação os gastos no espetáculo apareciam como limitadores, em 1980 (momento de inflação descontrolada e crise econômica profunda) a lembrança de uma montagem com recursos projetava uma afirmação positivada a respeito do lugar social do teatro profissional.

\section{Contraponto: "Uma nova consciência no teatro brasileiro?”}

A palavra aprofundar está vindo demais em tudo que eu falo, talvez como um reflexo de eu estar sentindo que em outros campos totalmente diferentes dos meus, totalmente opostos às minhas propostas um aprofundamento pode ser realizado. Eu não digo isso no teatro convencional, profissional feito no país. Diante desses Calabar era um espetáculo de extremo significado (PEIXOTO, 1973c).

Há na fita que estamos estudando um último dado relevante para a análise dos aspectos produtivos de Calabar. Trata-se de um contraponto: Peixoto menciona as limitações advindas de uma superprodução em comparação com o contexto produtivo do encenador Airton Kerensky, que à época dirigia o Centro de Pesquisa Ex-Teatro (Teatlab): "Vendo os dois espetáculos de Kerensky ontem eu sinto uma certa liberdade de trabalho, um trabalho mais liberto de uma série de problemas que tem um espetáculo

pela concepção cênica. No entanto, uma análise mais detida pode mostrar como a montagem aprofundou dados já indicados pela dramaturgia. Essa questão é debatida no artigo: HOTIMSKY, Nina. (2019). Aspectos da escrita cênica de "Roda Viva". Revista Aspas, 8(2), 122-141. Disponível em: $<$ https://www.revistas.usp.br/aspas/article/view/150266>. Acesso em: mai. 2019.

89 O próprio Fernando Peixoto falou sobre isso anos depois, em entrevista de 1980: "Antes contestação era mercadoria. A gente sempre soube disso. Não somos tão ingênuos assim. Um espetáculo de oposição, quando passava pela censura, dava bilheteria, Isso inclusive indicava que o caminho, a crítica do real, estava certo. Houve muita verdade nisso, mas também muita enrolação” (PEIXOTO, 1989b, p. 74).

${ }^{90}$ MICHALSKI, Yan. Como surgiu o novo Calabar. Jornal do Brasil, Rio de Janeiro, Caderno B, p. 20, 18 mai. 1980. 
profissional, uma superprodução. A presença do dinheiro por trás traz uma certa limitação” (1973c).

Kerensky é mencionado quatro vezes ao longo dos vinte e cinco minutos da reflexão de Peixoto sobre Calabar - recorrência que exige nossa atenção. Descreve-se "um trabalho realizado talvez até suas últimas consequências. Talvez contando com uma pesquisa de meios impressionais muito mais minuciosa e muito mais rica” (1973c). Os dois espetáculos do diretor assistidos por Peixoto na véspera, bastante inspirados pelo teatro de Jerzy Grotowski ${ }^{91}$, foram "Dos Mistérios” e “Dysagelium”. Dentro de uma proposta estética completamente diferente da sua, o diretor de Calabar enxergava um grau de aprofundamento na linguagem teatral que desejava realizar com a própria pesquisa artística.

Em sua atividade de crítico, Fernando Peixoto menciona Kerensky em dois textos. O primeiro deles, “Uma nova consciência no teatro brasileiro?”, foi escrito no mesmo mês em que Calabar foi censurado, novembro de $1973^{92}$. Ou seja: ao gravar suas reflexões sobre Calabar o diretor já estava trabalhando nesse texto. E não é apenas a cronologia que aproxima os dois documentos (a fita e o artigo), mas uma postura inquieta frente aos trabalhos teatrais de uma nova geração - sua linguagem, suas implicações políticas e sua forma de produção.

O título do texto faz uma citação ao livro de Luiz Carlos Maciel, Nova Consciência - Jornalismo Contracultural 1970/1972. Peixoto o escreve partindo de um pressuposto: o da crise do teatro brasileiro (situada por ele a partir da morte do Teatro de Arena e do "suicídio" do Teatro Oficina). Frente a ela, reconhece uma corrente nova, a de grupos de jovens atuando à margem do circuito comercial, frequentemente inspirados pelas ideias da contracultura. Daí a citação ao livro de Maciel, um dos intelectuais que primeiro escreveu sobre a contracultura no Brasil.

Em um capítulo dedicado às questões produtivas do teatro, cabe um parêntese. Ao falar sobre grupos críticos ao "teatro comercial”, no artigo em questão, Peixoto relativiza o que seria um teatro de empresa: o teatro nacional como um todo estava falido, e os produtores assumiam grandes riscos a cada trabalho. A experiência recente

91 Encenador polonês que viveu entre 1933 e 1999, autor de "Em busca de um teatro pobre". A influência de Grotowski foi bastante grande no teatro brasileiro dos anos 1970, especialmente entre artistas que buscavam um teatro ritual e um aprofundamento no trabalho corporal dos atores.

${ }^{92}$ No fim do artigo consta a informação: Rio, novembro de 1973. O texto foi parcialmente publicado em 17 de dezembro do mesmo ano, em Opinião $\mathrm{n}^{\circ}$ 58, e publicado na íntegra no livro "Teatro em movimento". O segundo texto de Peixoto sobre o encenador chama-se "Sobre Airton Kerensky", e é de março de 1974. 
com Calabar certamente o comprovava. Também o espetáculo Um grito parado no $a r^{93}$, que Peixoto dirigiu meses antes de Calabar (o espetáculo estreou em abril de 1973), fazia um debate sobre a crise do teatro profissional - que envolvia aspectos econômicos e de sentido social:

Muito de tudo isso está teatralizado na última peça de Guarnieri, Um Grito Parado no Ar. Um personagem, ator, fala: fazer teatro é sofrer no paraíso. Esta vocação masoquista define muito do teatro nacional de hoje, quando produzir teatro significa, sobretudo, manter viva a ideia de teatro sem levar em conta o significado desta ideia ou deste teatro. Uma reflexão desta ordem poderia ser especulada pelos críticos (existem?). Pelos que fazem teatro o único tipo de pensamento cabível é “como continuar” (PEIXOTO, 1989b, p. 141).

A dramaturgia de Um Grito Parado no Ar trata justamente de um grupo de teatro que tenta manter sua atividade em circulação no âmbito profissional. Há uma estreia marcada, o prazo se aproxima, mas o espetáculo ainda não está pronto. O diretor tenta conduzir com os atores improvisos que levem em conta o cotidiano do povo brasileiro, mas o trabalho é constantemente interrompido por conflitos pessoais e por limitações financeiras. Um dos atores precisa a todo tempo sair da sala de ensaio para negociar com “os home” - pessoas que vêm cobrar as dívidas do grupo. Os equipamentos técnicos são confiscados (a caixa de iluminação, refletores, o gravador), a energia elétrica é cortada, e os profissionais de teatro insistem em seguir. Nessas condições, que tipo de aprofundamento poderia ser atingido? Peixoto menciona Um Grito Parado no Ar como uma obra que ilustra a seguinte conclusão:

ninguém sabe exatamente o que significa espetáculo "artístico" ou "comercial”. Estão todos em busca de um equilíbrio financeiro imprevisível, numa roda viva que os transforma, a todos, numa coisa só, deixadas de lado as sutilezas estruturais: uma coisa culturalmente indefinida, praticamente aventureira e socialmente pouco responsável (PEIXOTO, 1989b, p. 141).

Apesar da dureza dessa descrição, dureza que aproximava velhos e novos artistas de teatro, há um esforço no texto de Peixoto em não criar julgamentos precipitados sobre o teatro que a nova geração experimentava. Sua proposta ao escrever

\footnotetext{
${ }^{93}$ A dramaturgia de Um grito parado no ar era de Gianfrancesco Guarnieri, e a realização da peça ficou a cargo da Othon Bastos Produções Artísticas. A peça estreou em São Paulo em julho de 1973, mas antes disso realizou apresentações em diversas cidades: Curitiba, Blumenau, Florianópolis, Porto Alegre, Pelotas, Caxias do Sul, Brasília, Belo Horizonte e Salvador.
} 
“Uma nova consciência no teatro brasileiro?” foi assistir a alguns espetáculos desses grupos jovens, entrevistar artistas envolvidos e mostrar semelhanças e diferenças entre eles. Ele não pretendia “separar o joio do trigo" prematuramente; evitava reprimir experiências que, embora frequentemente confusas, poderiam trazer vida ao teatro brasileiro de amanhã (PEIXOTO, 1989b, p. 140). Foi nesse contexto que ele assistiu “Dos Mistérios” e “Dysagelium”, e entrevistou Kerensky - visivelmente o encenador que mais lhe interessou dentre os jovens pesquisados. O diálogo entre os dois artistas ficou parcialmente registrado no artigo de 1973. Posteriormente, na crítica "Sobre Airton Kerensky” publicada em 1974, Peixoto incluiu na íntegra os “5 Manifestos do Centro de Pesquisa Ex-Teatro escritos por Airton Kerensky”. Aproveitou para enfatizar pontos dos manifestos que lhe interessavam, e levantar possíveis problemas nas propostas do colega.

Do ponto de vista da produção, Kerensky foi um defensor dos pequenos teatros. Suas duas peças acima mencionadas eram apresentadas em uma sala de aula vazia da Aliança Francesa de Botafogo. Em um de seus manifestos, afirmou: "Sentimos necessidade de implantação de pequenos teatros (...) onde se cultivaria um novo espírito alheio ao consumo tão intrinsecamente vinculado às grandes salas” (KERENSKY apud PEIXOTO, 1989d, p. 53). Essa era outra posição possível no debate sobre a proporção das salas de espetáculo. Vianinha e Augusto Boal criticaram o Teatro de Arena por seu limitado número de lugares; para Vianinha, a massificação da crítica era uma necessidade política. Por outro lado, Kerensky defendia que as grandes salas instauravam uma relação mercantil, pouco afeita a um diálogo mais profundo entre a obra e o público. Em seus manifestos e na entrevista que concedeu a Peixoto, dizia buscar espectadores ativos, e o teatro como local de confronto. Dysagelium tinha apenas um ator em cena, e Dos Misterios, quatro atores. A pequena sala era ocupada por poucos atores e por poucos espectadores, ambos (atores e espectadores) disponíveis ao tipo de imersão e troca demandada pelo diretor.

Ao mesmo tempo, Kerensky não se dizia contra o teatro profissional: "Não posso ser efetivamente contra um teatro profissional, se este teatro leva a primeira imagem do teatro para lugares que nunca viram teatro" (KERENSKY apud PEIXOTO, 1989b, p. 156). E fazia uma crítica bastante concreta ao chamado teatro marginal: "Estou convencido, aliás, que o teatro chamado marginal, que se faz hoje no Rio, é um degrau para o teatro convencional. É um apêndice deste teatro” (KERENSKY apud 
PEIXOTO, 1989b, p. 155). Peixoto expressou uma preocupação parecida em algumas de suas produções como crítico, diferenciando os artistas teatrais que atuavam fora do mercado por opção crítica e aqueles que apenas esperavam a chance de serem contratados.

O grupo de Kerensky, Ex-Teatro, parecia buscar não uma oportunidade de inserção no mercado, mas uma prática artística diferente. Em um de seus manifestos, ele fala sobre certa covardia "que nos assalta, a nós, homens de teatro(...). Os ideais que sustentaram o verdadeiro humanismo foram substituídos pela farsa da sobrevivência, pela humildade na escolha do repertório, pela subserviência na linguagem” (KERENSKY apud PEIXOTO, 1989b, p. 156). Não é possível enquadrar Fernando Peixoto nessa descrição. Mas é compreensível que, esmagado pela perseguição das companhias politizadas da década anterior, pela estrutura de superprodução e pela castração da censura, Peixoto sentisse saudades de uma pesquisa de linguagem mais profunda.

Airton Kerensky não estava sozinho em suas provocações. O próprio artigo de Peixoto o aproxima de diversos outros artistas. Inclusive de dois diretores da geração de Peixoto, já mencionados neste trabalho: Zé Celso, descrito como "o mais radical e também o mais corajoso e coerente na trajetória desesperada de uma aventura pessoal” (PEIXOTO, 1989b, p.144); e Amir Haddad, que em seu grupo “A Comunidade” atuava fora do âmbito profissional.

Foi nos anos 1970 que se consolidou no Brasil a hoje já muito debatida noção de um teatro de "grupo". Os grupos tinham por horizonte embaralhar arte e vida, experimentando um modo de criar e de existir sem hierarquias. Como define Mariângela Alves de Lima: “a História mostra que o modo de produção de uma arte adapta-se, por tortuosos caminhos, ao modo de produção predominante na sociedade em que essa arte é produzida” (LIMA in ARRABAL, LIMA E PACHECO. 1979, p. 45). O grupo seria uma "tentativa de eliminar do interior da criação teatral a divisão social do trabalho" (LIMA in ARRABAL, LIMA E PACHECO. 1979, p. 45).

Muitas vezes essa tentativa se dava pela exclusão da figura de um diretor, e a prática da criação coletiva. Mas na própria fala de Kerensky como diretor se expressa um tipo de preocupação parecida: "Não deve existir entre nós o "mais sábio”, ou o “mais inteligente” senão a efetividade na contribuição do trabalho comunitário" (KERENSKY apud PEIXOTO, 1989d, p. 50). Peixoto, um diretor de uma geração 
anterior, comentava essas afirmações com bom humor: dizia que esse é um "verdadeiro ideal de condições de trabalho para o teatro” (PEIXOTO, 1989d, p. 49). Para ele, as contribuições coletivas seriam preciosas para a construção de todo espetáculo teatral consequente, qualquer que fosse sua forma de produção.

As propostas de um teatro de grupo dos anos 1970 precisam ser pensadas sob dois aspectos históricos. Um deles é o contexto de estado de exceção: o regime militar proibia a própria reunião de pessoas, e todas as decisões políticas eram tomadas sem consultar a população. Neste contexto, mesmo o teatro profissional produzido de maneira mais convencional pode ter se beneficiado da visão do teatro enquanto trabalho coletivo. Vimos como a atriz Imara Reis valorizou o aspecto democrático da sala de ensaio de Calabar, em oposição à conjuntura de repressão. No caso da produção empresarial de Calabar, a censura conseguiu encerrar de uma vez aquela convivência democrática e afetiva. Os grupos tentavam fazer de sua convivência uma prática constante, quase que um fim em si mesmo. Claro que essa proposta também trazia contradições: a falta de estabilidade material; a dificuldade em estabelecer com os espectadores um laço tão significativo quanto o constituído entre os integrantes do grupo; a frustração frente a uma realidade política que seguia antidemocrática ${ }^{94}$.

Outro aspecto que precisa ser considerado para pensarmos a forma "grupo" é a já mencionada chegada da contracultura no Brasil. Vimos como o teatro de Zé Celso passou a se pautar por uma mudança radical nos costumes, e como essa atitude fez parte da cisão de Fernando Peixoto com o Teatro Oficina. Muitos outros grupos dos anos 1970 também estavam mais preocupados em modificar sua forma de viver do que em produzir espetáculos teatrais. Ao escrever “Uma nova consciência no teatro brasileiro?”, Peixoto se pergunta sobre a possibilidade de se constituir um teatro de contracultura. Voltaremos a esse tema mais tarde.

Mas o que lhe interessa especialmente em Kerensky não é tanto uma outra forma de viver, e sim a possibilidade de aprofundar-se em uma pesquisa de linguagem, ir "até as últimas consequências” em seu teatro. Diz Peixoto: "Eu não sei que tipo de trabalho seria esse. Que tipo de aprofundamento na teatralidade teria de ser buscado. Não é evidentemente o que é desenvolvido pelo Kerensky. Não é um trabalho grotowskiano que me interessaria” (1973c). Apesar de mencioná-lo tantas vezes, algumas coisas separam Peixoto de Kerensky: entre elas, a visão de mundo.

\footnotetext{
${ }^{94}$ Essas questões foram muito bem abordadas por Mariângela Alves de Lima (LIMA in ARRABAL, LIMA E PACHECO. 1979) em texto já citado.
} 
Ao mesmo tempo que expressa sua admiração pelas peças de Kerensky, em nenhum momento Peixoto abre mão de seus pressupostos políticos: nem na fita gravada como desabafo, nem nas críticas que escreve ao trabalho do encenador. Especialmente em "Sobre Airton Kerensky”, Peixoto convida o jovem artista a incluir as questões sociais em seu trabalho. Mesmo ao pesquisar processos inconscientes, afirma: "não posso me isolar ou abstrair da vida objetiva e histórica, do cotidiano e do sócioeconômico. Porque justamente penetram profundamente minha vida inconsciente. E o acesso à mesma só pode ser feito dentro de uma interação dialética entre eu e o mundo” (PEIXOTO, 1989d, p. 49). Em sua atividade de crítico, Peixoto ao mesmo tempo respeita os interesses de outro artista a respeito da vida inconsciente, mas observa que esta não existe apartada da realidade histórica.

$\mathrm{O}$ que Kerensky provoca em Peixoto enquanto questionamento diz respeito à forma de produção empresarial, e “até que ponto” (emprestando a expressão tão usada por Peixoto) essa forma limitaria um aprofundamento em suas pesquisas da linguagem teatral.

Há muitos outros “até que ponto" levantados por Fernando Peixoto na fita, e que serão analisados nos próximos capítulos. Antes de mencionar os problemas do contexto produtivo, o encenador levanta muitas dúvidas sobre suas próprias escolhas artísticas o que em um trecho já citado está expresso quando ele menciona uma possível “incapacidade em realizar o que pensa”. É importante explicitar a presença de autoquestionamentos de diversas ordens, pois as reflexões da fita não buscam culpabilizar a forma de produção por todas as dificuldades do processo criativo.

E há momentos em que o encenador considera a possibilidade de sua crise ter sido disparada unicamente pela violência da censura: “Ou até que ponto o espetáculo era exato. E até que ponto talvez tudo isso seja bobagem, e a crise venha só da paralisação do espetáculo. É possível que, apesar de tudo, fosse o meu espetáculo mais maduro” (1973c). A impossibilidade de Calabar encontrar seus espectadores é um dado que define a própria existência das fitas que estamos analisando. Veremos o que elas nos revelam a respeito do trabalho da equipe de direção sobre a dramaturgia e sobre a encenação em si. 


\section{Capítulo 2 - A dramaturgia de Calabar e as reflexões da equipe de direção}

As reflexões de Peixoto podem ser melhor compreendidas se lidas junto com a dramaturgia de Calabar. O texto foi o ponto de partida do trabalho de encenação, e seria representado na íntegra, sem cortes. O encenador imprimiu na peça elementos novos, mas a lealdade à dramaturgia era um pressuposto que até certo ponto balizava suas escolhas estéticas. Essa postura está ligada à de uma geração de artistas teatrais preocupados com a consolidação de uma dramaturgia e de uma encenação brasileiras, capazes de colocar em cena os debates sociais pertinentes à realidade nacional. Vimos como o Teatro de Arena e o Oficina, na década anterior, haviam trabalhado em prol desse projeto. Peixoto participou de ambas as empreitadas, e manteve as suas diretrizes após o esfacelamento dos dois coletivos.

A dramaturgia de Calabar foi editada e é de fácil acesso; a descrição e análise que constam nesse trabalho não substituem o contato direto com um texto poético e cheio de meandros. A primeira versão publicada da dramaturgia é a base fundamental para a análise. Foi ela que chegou a ser ensaiada em 1973. As edições mais recentes da peça, publicadas a partir de 1980, são bastante diferentes da edição original. Isso ocorre porque Chico, Guerra e Peixoto revisaram e modificaram o texto para a montagem do Calabar de 1980.

A primeira edição de Calabar foi lançada ainda em 1973. Peixoto registrou em nota de 13 de novembro sua ida à editora para buscar os primeiros cinquenta exemplares do livro (PEIXOTO in BUARQUE; GUERRA, 1980). Na festa de despedida do elenco, realizada após a dissolução da produção, os artistas foram presenteados com esses exemplares de Calabar, e em suas páginas deixaram recados uns para os outros ${ }^{95}$.

Uma reportagem da revista Veja em 21 de novembro daquele ano apresentou o lançamento da editora Civilização Brasileira. A notícia tinha destaque: ocupava quase uma página inteira do caderno de literatura, com direito a uma fotografia dos dramaturgos, um desenho retratando o Calabar histórico e uma crítica elogiosa de Geraldo Mayrink. O livro Calabar se manteve na lista dos dez mais vendidos publicado pela Revista Veja durante algumas semanas. A estreia do espetáculo foi interditada, mas

\footnotetext{
${ }^{95}$ Nina de Pádua levou o seu exemplar do livro para a entrevista. O mesmo contava com vários recados carinhosos de amigos e colegas.
} 
a dramaturgia seguia sendo lida. A censura era frequentemente menos rigorosa com materiais escritos do que com espetáculos teatrais ${ }^{96}$.

\section{Considerações iniciais sobre a dramaturgia}

A dramaturgia de Calabar não possui uma divisão em atos previamente estabelecida. Peixoto, já em seus primeiros estudos do texto ${ }^{97}$, procurou dividi-lo em duas partes. Essa divisão foi reforçada nos ensaios com o elenco, e os “dois atos” estabelecidos pela equipe de direção passaram a operar como uma categoria importante. Segundo Peixoto, decidiu-se terminar o primeiro ato com o frevo Não existe pecado do lado de baixo do Equador (1973).

Em Calabar o enredo não é exposto de maneira linear, e sim através de quadros (modelo semelhante ao adotado pelo Teatro de Revista ${ }^{98}$ brasileiro). Muitos dos acontecimentos que compõe a trama são narrados e muitos temas aparecem em forma de canção. É possível perceber no texto a influência das ideias de Bertolt Brecht, a busca por uma construção dramatúrgica épica. O texto não respeita uma estrutura dramática $^{99}$ tradicional, não há um rígido encadeamento causal entre as cenas, tampouco a predominância de conflitos intersubjetivos. Dois narradores auxiliam na costura da história: o Frei, portador do discurso oficial, e Bárbara, personagem que por vezes assume a voz crítica dos dramaturgos ${ }^{100}$.

A primeira parte da peça ocorre ainda durante a hegemonia do domínio português no Recife. O soldado Calabar, nascido no Brasil, abandona o exército português e vai lutar ao lado dos holandeses. O exército português vence os holandeses

\footnotetext{
${ }^{96}$ Miriam Hermeto (2010) analisa o assunto ao lidar com a peça seguinte de Chico Buarque, Gota d'água. ${ }^{97}$ A primeira versão mimeografada da dramaturgia, e também a segunda versão, possuem anotações de Peixoto em que ele divide o texto em "primeira parte" e "segunda parte". BUARQUE; GUERRA, 1973b e BUARQUE; GUERRA, 1973c.

${ }^{98}$ A pesquisadora Neyde Veneziano traz em seus livros uma análise detalhada sobre o Teatro de Revista brasileiro. Ela aborda a diversidade estética presente nos diferentes quadros que compunham um mesmo espetáculo. Havia números cômicos, quadros de fantasia, apoteoses. A intenção era agradar o espectador das mais diferentes formas, fazendo-o rir, se emocionar e se deslumbrar com a beleza dos cenários, dos figurinos - e das próprias vedetes.

99 Partimos de uma compreensão do gênero dramático e do gênero épico bastante debatida por Bertolt Brecht em diferentes textos teóricos. Um de seus textos importantes a esse respeito é "Notas sobre a ópera Ascenção e queda da cidade de Mahagonny (BRECHT, 2005, p. 25-38). Há uma boa sistematização a esse respeito no livro "O teatro épico", de Anatol Rosenfeld (1965). Esse livro foi um dos primeiros sobre o assunto no Brasil, em uma época em que Brecht ainda havia sido pouco traduzido para o português. Por isso, foi um livro importante para os encenadores das décadas de 1960 e 1970 interessados no teatro épico.

${ }^{100}$ Os próprios dramaturgos fizeram essa observação sobre a personagem Bárbara em entrevista ao DCE da PUC. (BUARQUE; GUERRA, 1973b).
} 
em uma batalha, e com isso captura Calabar - agora prisioneiro de guerra acusado de traição. Acompanhamos Bárbara, sua companheira, tentando obter ajuda de antigos colegas para salvar seu amado. São eles: Henrique Dias, Camarão e Sebastião de Souto. Esses soldados são ironicamente chamados de "heróis”, mas nada fazem de heroico. Também nos é apresentada a personagem Anna de Amsterdam, uma prostituta que trabalha durante a guerra, atendendo a clientes de ambos os lados da trincheira. Apesar dos esforços de Bárbara, o governante Mathias de Albuquerque condena Calabar, que é morto e esquartejado. Anna consola a viúva, e sugere-se um início de relação amorosa entre elas.

O governador Mathias é um personagem contraditório: representante oficial de Portugal no Brasil, mas nascido brasileiro, explora o país mas diz que o ama. Tem consciência de que suas conquistas, feitas em nome de Portugal, favorecem a Espanha, por conta da conjuntura internacional da União Ibérica ${ }^{101}$, e isso o revolta. O personagem deixa o Brasil logo após a execução de Calabar. O ator que representava Mathias volta ao segundo ato representando Maurício de Nassau. Os dramaturgos afirmaram em reportagem à época que previram essa opção cênica (posteriormente acatada por Peixoto ${ }^{102}$ ). Segundo Ruy Guerra, Mathias e Nassau “representam a mesma coisa: a ideia que o poder tem sobre a traição. Mas ambos são colonizadores e vinculados aos interesses de suas metrópoles” ${ }^{103}$.

A chegada de Maurício de Nassau marca o início da segunda parte da peça, segundo a divisão de Fernando Peixoto. Fica subentendido que os holandeses venceram os portugueses na disputa territorial pela região. O governador chega ao Recife para administrá-lo, representando interesses do Estado holandês e da Companhia das Índias Ocidentais ${ }^{104}$, um grupo comercial poderoso à época, interessado em comerciar o açúcar

\footnotetext{
101 A ação da peça se passa em 1635. Nesse período (mais exatamente entre 1580 e 1640) Portugal havia sido anexado pela Espanha. Após o desaparecimento de Dom Sebastião e a morte de seu tio Cardeal Henrique de Portugal houve uma crise de sucessão do trono português, que desembocou no domínio espanhol. Os historiadores cunharam o termo "União Ibérica” para designar esse momento histórico. Há trechos da peça em que Mathias reclama contra sua sujeição ao reinado espanhol. Essa questão intensifica o problema da traição: quem Calabar traiu ao trair o exército de Mathias de Albuquerque? Traiu o Brasil, Portugal ou a Espanha?

102 Peixoto escreveu sobre a opção em texto que seria publicado no programa do espetáculo: "É proposital e fundamental, no espetáculo, que Mathias e Nassau sejam interpretados por um mesmo ator: ambos significam a mesma coisa, como vassalos do colonialismo, e ambos sofrem quase que o mesmo processo interior, ainda que em circunstâncias diversas”. (PEIXOTO, 1989c, p. 156).

$103 \mathrm{O}$ depoimento foi publicado em reportagem da Revista Veja. O texto falava sobre a dramaturgia e anunciava o futuro espetáculo, antes mesmo de serem iniciados os ensaios para o espetáculo. CALABAR Revisado. Revista Veja, São Paulo, p. 84, 25 jul. 1973.

104 Peixoto define da seguinte maneira a Companhia das Índias Ocidentais: "sociedade por ações, organizada na Holanda em 1621, visa multiplicar a acumulação de capital, justificada e apoiada pelo
} 
produzido no Brasil. Nassau é uma espécie de líder populista. Ele faz melhorias na cidade, traz um séquito de cientistas e artistas, estabelece a liberdade de culto (e o Frei católico rapidamente se alia a esse líder protestante). Ao mesmo tempo, Nassau não deixa de ser cobrado pelos colonizadores que representa. O personagem do Consultor constantemente lhe pressiona a esse respeito, censurando gastos excessivos e incentivando a continuidade de batalhas coloniais, a ampliação de seus territórios.

Bárbara envolve-se amorosamente com o soldado Sebastião de Souto e com Anna de Amsterdam, mas segue lembrando do amado Calabar. Souto acaba enlouquecendo e sendo morto pelos holandeses. Bárbara questiona o Frei sobre a facilidade com a qual mudou de lado, enquanto Nassau confessa que se deixou seduzir pelo Brasil. A peça termina com Nassau sendo obrigado a voltar para a Holanda, por não cumprir bem seu papel de colonizador. Fica apontado que outro governante virá, mais disposto a realizar a exploração eficiente das riquezas brasileiras em prol da Holanda.

No Arquivo Fernando Peixoto consta a primeira versão do texto mimeografada, com anotações do diretor e a data 12 de junho de 1973. Isso quer dizer que aproximadamente três meses antes de iniciar os ensaios o encenador já investigava a dramaturgia e trabalhava junto aos autores em alguns ajustes. O fato de Peixoto ter participado da finalização do texto reforça como este foi base para o trabalho de montagem.

Esse documento singular dá a ver o método de Peixoto na lida com o texto e registra certas posições do encenador frente ao material dramatúrgico. Em um estudo feito a lápis ele faz anotações de diversas ordens: numera 77 cenas do texto, lista os personagens (subdividindo-os entre os que seriam interpretados pelos "atores I" e os que ficariam a cargo da figuração), passa a limpo frases que considera importantes, anota pensamentos com palavras-chave, visualiza movimentos de luz e transformações de cenário, registra materiais que serão necessários (figurinos, objetos de cena). Em uma provável segunda leitura, e já a caneta, Peixoto divide o texto em 22 blocos que numera com algarismos romanos, e escreve um resumo de cada bloco, que sintetiza as ações essenciais das cenas ali contidas. Seria proveitoso respeitar essa divisão em blocos ao tratar da dramaturgia aqui, mas ocorreram mudanças estruturais no texto que impediram esse procedimento.

calvinismo, utiliza a pilhagem e o assassinato, o saque e a pirataria, no momento em que o capitalismo dá seus primeiros passos no continente europeu”. (PEIXOTO, 1989c, p. 153). 
Numa fase posterior, após a censura, ao gravar sua descrição crítica da encenação, a equipe de direção também teceu diversos comentários sobre os problemas e as qualidades da dramaturgia. Essas reflexões foram retomadas por Peixoto na fita que gravou sozinho. Certamente o corpo a corpo com o texto experimentado na sala de ensaio trouxe novos elementos para a análise do diretor.

\section{Sobre as rubricas: sonoplastia, iluminação e indicações para o coro}

É importante considerar que o texto de Chico Buarque e Ruy Guerra para o espetáculo já sofre seu primeiro processo de modificações no diálogo com o encenador Peixoto. Diante disso, as rubricas, que traduzem não apenas estados emocionais ou ações das personagens, mas também elementos cênicos, se tornam fundamentais para uma compreensão dos interesses do espetáculo projetado. O estudo das rubricas é revelador da passagem de um texto para a cena.

Quando Peixoto passou a integrar os debates sobre a dramaturgia em processo, Chico e Guerra já haviam escrito rubricas numerosas e detalhadas. A permanência da maioria das rubricas mesmo após o trabalho do encenador com os dramaturgos indica que ele as considerava potentes. O cuidado com as indicações de iluminação e sonoplastia é uma marca dos dramaturgos, um cineasta e o outro compositor (dado que foi esmiuçado por Ruy Guerra em sua entrevista) ${ }^{105}$. A luz e a musicalidade em Calabar são muito importantes para a construção de sentidos.

Em processos teatrais orientados por um trabalho coletivizado, frequentemente as rubricas registram descobertas dos atores e do encenador realizadas durante os ensaios. Esse não foi o caso de Calabar. Ruy Guerra afirmou em entrevista que "o que está no livro são as nossas propostas (...). Isso é meu lado um pouco diretor que

\footnotetext{
105 Nina -O texto possui muitas rubricas de luz e música incidental. Essas marcações também foram propostas de vocês? Ou teve coisas que surgiram nos ensaios?

Ruy - O que está no livro são as nossas propostas. Isso é meu lado um pouco diretor que extrapola. Mesmo os roteiros sempre tem... Pra mim é muito difícil escrever. Demoro mais pra escrever meus roteiros de cinema porque em vez de eu trabalhar a parte literária e depois pegar um diretor e trabalhar a parte da mise-en-scène, a parte do espetáculo, eu já escrevo pensando um pouco num tipo de mise-enscène que não obrigatoriamente aquele. Mas eu não consigo avançar sem eu ter uma visualização do espetáculo além da dramaturgia propriamente dita. Eu já tenho sempre um espetáculo na minha frente. E às vezes até desvia a dramaturgia. Faz parte do meu processo, que é um processo híbrido. A mise-enscène pra mim não tá separada da dramaturgia. A luz não tá separada da dramaturgia.

Nina - Também tenho impressão de que nas rubricas a luz caminha junto com o som. Faz parte da sua estética?

Ruy - É, faz. É que são subordinados a uma estética visual.

GUERRA, Ruy. Entrevista sobre Calabar. Entrevistadora: Nina Hotimsky. São Paulo, mar. 2018.
} 
extrapola”106. Guerra falou de como seu processo criativo inclui visualizar o espetáculo, a mise-en-scène.

Analogamente, quando o músico Chico Buarque escreve para teatro, as situações cênicas são sempre acompanhadas de sonoridades. O texto é inseparável das canções e ambientações sonoras que o integram ${ }^{107}$. A ênfase das rubricas no campo da sonoplastia parece mais do que evidente num espetáculo musical. Em Calabar, ela projeta uma visão poética e crítica dos dramaturgos sobre o espetáculo. O exame de algumas das cenas desse ângulo evidencia aspectos dessa visão.

Claro que rubricas são sugestões dos autores, que (mesmo quando inicialmente aprovadas pelo diretor) nem sempre são respeitadas pela montagem. Por vezes as experimentações na sala de ensaio levam para outros caminhos. No caso de Calabar, depoimentos dos artistas envolvidos sugerem que elas estavam sendo bastante respeitadas. No que se refere à sonoplastia, o processo foi conduzido através do trabalho especializado de alguns artistas, que se concentravam em suas respectivas funções. $\mathrm{O}$ diretor musical Dori Caymmi tinha como principal tarefa trabalhar o canto com os atores, e disse que "não se metia” com certas decisões. Os arranjos eram feitos por Edu Lobo fora da sala de ensaio, os playbacks (que incrementavam as canções, mas também entrariam durante as cenas, como música incidental) eram gravados sem a sua intervenção, e Dori também não tinha contato cotidiano com os dramaturgos. Os demais músicos só chegaram ao final do processo de ensaios, “quando já estava praticamente tudo pronto" ${ }^{108}$; não teriam tempo hábil para criar intervenções sonoras para além das previamente definidas. Era uma equipe de instrumentistas de alta qualidade, cuja função seria executar as composições. O próprio Peixoto afirmou que não houve tempo de trabalhar os arranjos tocados ao vivo com o mesmo cuidado depositado nos playbacks (1973).

No que se refere à iluminação, Mário Masetti relatou que o espetáculo seria demarcado pela luz ${ }^{109}$ - descrição que se aproxima da sugerida pelas rubricas. Segundo ele, a encenação não fazia uso de coxias, de forma que os atores ficavam todo o tempo em cena. Para atribuir foco em cenas mais íntimas, e considerando o elenco numeroso, o

\footnotetext{
${ }^{106}$ GUERRA, Ruy. Entrevista sobre Calabar. Entrevistadora: Nina Hotimsky. São Paulo, mar. 2018.

${ }^{107}$ No caso das canções de Calabar, as letras são de Chico Buarque e Ruy Guerra, e a música é de autoria de Chico.

${ }^{108}$ CAYMMI, Dori. Entrevista sobre Calabar. Entrevistadora: Nina Hotimsky. Rio de Janeiro, jan. 2018.

${ }^{109}$ MASETTI, Mário. Entrevista sobre Calabar. Entrevistadora: Nina Hotimsky. São Paulo, nov. 2016.
} 
recurso de escurecer partes do palco seria imprescindível. Peixoto também descreveu a luz seccionando as cenas no espaço. Infelizmente com o processo da censura a parte de iluminação (que já havia sido idealizada) não pôde ser finalizada ${ }^{110}$.

Há um aspecto das rubricas que incentivou a criação de um enunciado próprio da encenação. Trata-se das indicações cênicas envolvendo o coro: moradores do Recife, soldados portugueses e holandeses e outros personagens que pouco falam. A dramaturgia prevê a sua presença e seu canto em diversas situações. Peixoto elegeu o coro como dado fundamental para a sua concepção da encenação. Para realiza-la, foi além do que as rubricas descreviam. O coreógrafo e diretor assistente Zdenek Hampl, por sua vez, trabalhou com o elenco para criar as movimentações dessas figuras. Entre a cena projetada pelos dramaturgos, a concepção estruturada por Peixoto e o trabalho corporal conduzido por Zdenek certas dissonâncias foram produzidas. Esse tema será melhor desenvolvido no capítulo 3 da dissertação.

\section{$\underline{\text { Calabar cena a cena }}$}

O texto de Calabar começa com um painel do domínio dos portugueses no Recife. Moradores cantam a reza Miserere Nobis; um Frei narra a prosperidade da colônia; em um acampamento militar, alguns soldados dormem e outros torturam um prisioneiro, que grita; o Governador e Comandante ${ }^{111}$ Mathias de Albuquerque se barbeia. Peixoto anotou em seu texto uma palavra-chave: as ações seriam "simultâneas” (BUARQUE; GUERRA, 1973b). O painel social contraditório constitui-se pela sobreposição ${ }^{112}$.

A presença da tortura era uma clara denúncia às práticas do regime militar, e interessava ao encenador reforçar esse dado de atualidade. Peixoto anota: "acentuar

\footnotetext{
${ }^{110}$ Peixoto (1973) afirmou: "A iluminação nunca foi realizada, a gente nunca teve uma ideia concreta de clima, nem de (vamos dizer assim) seccionar o espetáculo. Seccionar cenas no espaço. Poder iluminar umas e escurecer outras. Não houve um trabalho de iluminação que poderia dar outra dimensão para a peça”..

${ }_{111} \mathrm{O}$ personagem se autodenomina "Governador e Comandante Supremo das quatro capitanias nordestinas de Pernambuco, Itamaracá, Paraíba e Rio Grande”. (BUARQUE; GUERRA, 1974, p. 3).

${ }^{112}$ Roda Viva, dramaturgia anterior escrita por Chico Buarque, também começa com um grupo de fiéis miseráveis rezando: "(Povo esfarrapado entra em procissão entoando o canto religioso). Aleluia / Falta feijão na nossa cuia / Falta urna pro meu voto / Devoto / Aleluuuuuuia” (BUARQUE, 1968, p. 15). Embora o recurso seja muito parecido, em Roda Viva essa reza sofria um corte brusco através da entrada de Benedito como apresentador de televisão. O povo miserável imediatamente se transformava em garotas-propaganda, expressando a indústria cultural impositiva e falsamente alegre. A pobreza era forçada a sumir de cena. Em Calabar, a capacidade de incluir dados contraditórios na mesma cena, compondo um painel dialético, pode ser vista como um amadurecimento do autor.
} 
tortura” (BUARQUE; GUERRA, 1973b). A reza Miserere Nobis (que traduzida do latim literalmente significa “tende piedade de nós”) ${ }^{113}$ também merece algumas anotações de Peixoto. Ele escreve: "Povo na miséria (sócio-econômico). Recurso: Deus (via Frei). MISERERE = resistência passiva" ${ }^{114}$.

A transformação de um texto litúrgico em descrição da pobreza é sugerida pela divisão dos versos presente na dramaturgia: "Miserere nobis /Miserere nobis / Miserê [Grifo nosso]/ Renó / Bis”. A reza entoada coletivamente circunscreve a ação em um contexto social de pobreza ${ }^{115}$, enfrentada (neste primeiro momento) pacificamente. Veremos como o discurso da encenação incutiu uma passagem gradativa de um povo pacífico para um povo militante e organizado. A sugestão original da dramaturgia expressa na rubrica - era de a reza vir como um som em off ${ }^{116}$. Na encenação Peixoto contou com seu coro de atores numeroso para compor ao vivo o grupo de fiéis.

Enquanto se barbeia, o representante de Portugal Mathias de Albuquerque dita ao escrivão uma carta para Domingos Fernandes Calabar. A data da carta é 1635, e o local, Arraial do Bom Jesus. Mathias tenta convencer Calabar a voltar aos Serviços d'El Rey; fica subentendido que o soldado havia decidido lutar ao lado dos holandeses. A cena termina com um solilóquio em que Mathias descreve Calabar (“mulato bonito, (...) guerreiro como ele não sei mais se haverá (...) Mameluco, louco, pelo brabo, pixaim”) e narra seu desinteresse em voltar para o lado dos portugueses (“O rebelde, em língua de serpente / Mandou-me recusar, / Como um bicho esquisito destas terras / Que pensa dum jeito impossível de pensar”). Mathias se pergunta: “Por que é que ele foi para lá?” (BUARQUE e GUERRA, $1974^{117}$, p. 4). Nos trechos destacados, Calabar vai sendo constituído como um brasileiro. Um bicho esquisito dessas terras (a metáfora da serpente será retomada na canção “Cobra de Vidro”), que recusa as ofertas de Mathias

\footnotetext{
${ }^{113}$ Miserere Nobis e faz parte da reza Agnus Dei, introduzida na missa pelo Papa Sérgio I (687-701) e incorporada pela liturgia católica e anglicana. Durante as missas, essa reza é entoada no momento da fracção do pão.

${ }^{114}$ Grifos e textos em caixa alta presentes no original.

115 Essa reza também nos remete à canção Misere Nobis, de Gilberto Gil e Capinam, que integra o álbum Tropicália, lançado em 1968 pela Philips. Nela se dá um jogo entre a musicalidade religiosa (com a presença do órgão como instrumento e o canto se assemelhando aos cantos gregorianos) e os temas materiais (a metade do pão para todos, a banana e o feijão na mesa), além da alusão ao regime militar (se soletram as palavras "Brasil", "Fuzil" e "Canhão", e ouvem-se tiros de canhão ao final da gravação). Na canção de Gil e Capinam, "Misere” já pode ser associada a "miséria” ou “miseráveis”.

116 "Som em off” significa que a reza seria reproduzida a partir de uma gravação, e não cantada ao vivo por um grupo de atores.

117 O exemplar de Calabar utilizado durante a escrita deste trabalho foi produzido na quarta edição, e data de 1974. Este exemplar foi comparado com um de 1973, e foi averiguado que não houve mudanças da primeira edição para a quarta. Assim, mantivemos a data de 1974 apenas para manter o rigor quanto à paginação das citações.
} 
por um aumento de salário e de patente militar. Se não foi por prestígio ou por dinheiro, alguma outra razão o teria levado "para lá". Peixoto sintetiza o problema: "Por que a traição?” (BUARQUE; GUERRA, 1973b).

O Frei narra que Calabar levou consigo uma mameluca, Bárbara. A personagem surge para cantar Cala a Boca Bárbara, um canto de amor a um guerreiro. Canto proibido ou perigoso: os versos de amor são intercalados com um coro que manda a mulher se calar. Mas na exigência de silêncio subjaz a memória daquele nome proibido, bastando unir a palavra “cala” ao início do nome da amada, Bárbara. Como observou Meneses (2001, p. 124), “a própria palavra Calabar, reinventada, passa a condensar em si o 'Cala a boca' que estigmatiza a peça e os tempos que a geraram. (...). E o nome de Calabar conterá o nome de Bárbara: fusão de amantes apaixonados". A canção sintetiza liricamente um tema da dramaturgia. O poder instituído ameaça matar Calabar, e proíbe que se fale nele, mas contra essa “civilização” violenta haverão bárbaros para cultivar a memória da revolta.

Observamos nos cadernos de Fernando Peixoto que o diretor sugeriu uma mudança na ordem das canções, já mencionada neste trabalho. Originalmente Bárbara surgiria pela primeira vez para cantar a canção Tatuagem. Aparentemente foi Peixoto que sugeriu introduzir a personagem com a canção Cala a Boca Bárbara.

Terminada a canção, Bárbara fala diretamente ao público, assumindo-se como uma segunda narradora (além do Frei). Mas enquanto o Frei simplesmente conta a história, Bárbara por vezes rompe a convenção teatral e assume-se como uma espécie de “porta voz dos dramaturgos” (BUARQUE; GUERRA, 1973a, p. 21). Ela pede atenção: "Não a atenção que costumais prestar aos oradores sacros. Mas a que prestais aos charlatães, aos intrujões e aos bobos da rua” (BUARQUE e GUERRA, 1974, p.6). Esse trecho é uma colagem de Elogio da Loucura, de Erasmo de Rotterdam, com o qual Calabar - Elogio da Traição tece intertextualidades ${ }^{118}$. Segue em pauta o tema: quem narra a História? Oradores sacros, como os padres que em suas cartas documentaram a colonização do Brasil? Ou os bárbaros, as mulheres, as mamelucas, os vencidos? Vimos que os dramaturgos estudaram documentos oficiais produzidos por líderes religiosos no

\footnotetext{
${ }^{118}$ Ruy Guerra explicou em entrevista: “Quando a gente põe um Elogio da Traição é tirado do Erasmo de Rotterdam, O Elogio da Loucura, que é justamente uma inversão de valores, quando o cara faz um elogio da loucura. Aí, a loucura, como valor positivo, numa época em que se dá assim como um estigma (BUARQUE; GUERRA, 1973, p.6)”. No Brasil de 1973, era a traição (principalmente a traição à pátria) que era estigmatizada socialmente, e que precisava ser debatida.
} 
século XVII, e incluíram trechos no texto ${ }^{119}$ - nas primeiras edições de Calabar constava inclusive uma bibliografia histórica. Mas sua abordagem buscava outro olhar para os mesmos fatos. Guerra afirmou em entrevista à época a intenção de "questionar a própria oficialização da História” (BUARQUE; GUERRA, 1973a, p. 26).

O Frei português volta a narrar. Descreve a entrada do "pecado nas terras brasileiras” - a chegada dos holandeses. Cria-se em cena um banquete holandês, que segundo a rubrica “constitui-se numa orgia muda” (BUARQUE e GUERRA, 1974, p. 6). A representação de colonizadores não católicos realizando uma orgia poderia ser um retrato bem-humorado da visão católica sobre os mesmos. Mas essa sugestão dramatúrgica teve implicações mais profundas na encenação.

O chefe holandês já se anuncia como vencedor da guerra contra os portugueses; promete liberdade de culto ao padre católico, e outras liberdades para os moradores do Brasil, com o objetivo de assegurar a produção do açúcar. Confidencia ao Frei que é católico, e se faz de protestante para garantir seus pagamentos. Novamente o tema da traição, que aparece de diversas formas durante a peça. Nas suas anotações sobre a dramaturgia, Peixoto privilegia o dado material da cena. Ele dá ao trecho o subtítulo “Com açúcar e com traição”120: “Contradição aparente da cena: católicos e protestantes. Na verdade: AÇÚCAR. Açúcar = o pó branco. Domínio econômico é o que importa à Cia. das Índias Ocidentais. (Carregamentos de açúcar podem entrar) (BUARQUE; GUERRA, 1973b”. Sua leitura estrutural é a de que os conflitos políticos e religiosos expostos em cena tem uma motivação econômica. E uma solução cênica já é aqui esboçada: incluir figuras que carregam sacos de açúcar por trás de cenas da peça. Essa ideia, que não chegou a ser realizada, voltou a ser mencionada na conversa com Masetti $^{121}$.

Uma grande traição acontece: Sebastião de Souto, antigo parceiro de Calabar, prepara uma emboscada. Ele revela aos holandeses que os portugueses se aproximam de

\footnotetext{
${ }^{119}$ Uma das principais referências estudadas por Chico Buarque e Ruy Guerra foi o livro O Valeroso Lucideno, de Frei Manoel Calado. A obra é citada na Bibliografia Histórica presente nas primeiras edições de Calabar (BUARQUE; GUERRA, 1974, p. 94). Em sua dissertação, o historiador Christian Alves Martins expõe trechos da dramaturgia que foram criados a partir da colagem dos escritos de Calado (MARTINS, 2007).

${ }^{120}$ Em referência bem-humorada à canção "Com açúcar, com afeto”, grande sucesso de Chico Buarque, lançada em 1967.

121 "A cena da orgia holandesa, talvez tivesse faltado gente pra caracterizar o acampamento militar holandês. E tinha uma ideia que eu tinha aí que eu nunca fiz, não deu pra fazer. Era um momento que eu sentia que podia talvez se utilizar gente passando com sacos de açúcar por trás da cena, entende? Pra não mostrar só a orgia mas mostrar que por trás daquela orgia tinha uma movimentação de trabalho e de saque. Quer dizer, o açúcar sendo transportado por escravos” (PEIXOTO; MASETTI, 1973).
} 
Porto Calvo, mas mente sobre as dimensões da tropa. Uma grande expedição se aproxima, e ele a descreve como alvo fácil, provocando um erro estratégico do exército holandês. O Frei age como seu cúmplice. É essa mentira que leva à captura de Calabar pelos portugueses.

Durante a orgia a personagem Anna de Amsterdam se apresenta cantando: "Eu dormi com um protestante / E um católico depois / Mas a mim ninguém garante / Qual é o melhor dos dois (...). Quando perco alguma guerra / Eu não perco a profissão / Muda só minha bandeira/ Como muda o rufião” (BUARQUE; GUERRA, 1974, p. 8-10). Em suas anotações Peixoto define: “Católico ou protestante - o problema em termos de sexo. (Qual a posição “ideológica” da mercadoria?) (BUARQUE; GUERRA, 1973b)”. Os termos, ligados ao materialismo dialético, reforçam a inscrição teórica e política do diretor. Era sob esse viés que ele lia a peça, e que pretendia construir a encenação. Na conversa de Peixoto e Mário, eles concordam que Anna realiza um "resumo ideológico da cena toda” (1973). À mercadoria não importa se o consumidor é católico ou protestante. No Brasil das décadas de 1960 e 1970, também se revestiam de morais os problemas econômicos e políticos ${ }^{122}$. A Marcha da Família com Deus pela Liberdade defendia a moralidade dos lares ou a manutenção dos privilégios da classe dominante? Em 1964, esse movimento surgiu como uma reação às promessas de reformas de base feitas por João Goulart. Marchava-se contra a reforma agrária e a estatização de refinarias de petróleo, mas falava-se em valores abstratos como Deus, Família e Liberdade.

A cena seguinte começa com a Canção dos heróis, que não foi gravada em disco: trata-se de uma canção necessária para a cena ${ }^{123}$, mas que deslocada da peça não se sustentaria como obra musical autônoma. A canção é cantada por três personagens, que com ela se apresentam, um de cada vez. Todos são soldados do exército português. Henrique Dias é um negro que luta ao lado dos brancos; Camarão é um índio catequizado; e o brasileiro Sebastião Souto é o antigo parceiro de Calabar que o traiu ${ }^{124}$.

\footnotetext{
${ }^{122}$ A mesma tendência se verifica no Brasil de 2019.

${ }^{123}$ No Calabar de 1973 a música seria um "sambão", como Peixoto descreve na fita. Nina de Pádua em entrevista confirmou lembrar-se de um samba. Para o Calabar de 1980 Chico Buarque compôs outra melodia e adicionou alguns versos, criando o Forró dos heróis. Marcus Vinicius, diretor musical da montagem de 1980, gentilmente cedeu uma gravação de Chico cantando essa canção inédita. Ela também pode ser ouvida interpretada pelos atores, na gravação da peça que consta no CCSP.

${ }^{124}$ A letra completa da canção é a seguinte:

"O meu nome é Henrique Dias/Se a memória não me falha/ Ganhei os dias do nome/No negrume da batalha/Troquei os pés pelas mãos/Um olho por uma medalha/Fiz das tripas coração/E da camisa, mortalha.
} 
Guerra (1973a) explicou em entrevista que os três homens realmente existiram no Recife do século XVII. Foram os heróis oficiais daquela época, e "até hoje são apresentados como heróis”.

Peixoto e Masetti comentam que essa cena era originalmente uma sátira à nota comemorativa de 500 cruzeiros $^{125}$, que foi lançada em 1972 nas comemorações do sesquicentenário da independência brasileira. Ela retratava rostos fortes e corajosos de índios, negros e brancos lado a lado, como se houvessem construído juntos um projeto coerente de nação. A História oficial escondia a violência dos colonizadores portugueses para com os negros africanos escravizados e os índios brasileiros subjugados. Há nessa sátira uma semelhança com dois trabalhos realizados por Peixoto em 1972: Frei Caneca, feito dentro das comemorações do sesquicentenário da independência, e A Semana, que marcava os cinquenta anos da Semana de Arte Moderna de 1922 (PEIXOTO, 1989d, p.138). O Regime Militar narrava a história brasileira de acordo com seus interesses, e os homens de teatro procuravam problematizar os significados políticos subjacentes a essas festividades oficiais.

Na gravação da conversa sobre o espetáculo, Peixoto afirma: “Os três heróis eu achava muito legal a forma deles se apresentarem como trio de vocalistas, um negócio de filme da Atlântida. Eu acho que ridicularizava bastante a ideia dos heróis, e a música ajudava demais” (1973). Esse trecho da fita mostra como são delicadas as fronteiras entre dramaturgia e encenação. A inspiração nos filmes da Atlântida (companhia brasileira que produziu muitas chanchadas, gênero de grande apelo popular e baixo custo) provavelmente foi aprofundada na cena. Anos antes, Zé Celso já fizera referência às chanchadas da Atlântida como uma fonte de inspiração para a Tropicália:

Minha graça é Camarão/Em tupi, Poti me chamo/Mas do novo Deus cristão/Fiz minha rede e meu amo/Bebo, espirro, mato e esfolo/No ramerrão desta guerra/E se eu morrer não me amolo/Que um índio bom nunca berra.

Me chamam Sebastião Souto/E algumas coisas mais/Que com a morte se excita/E destrói o que lhe apraz/A vida, bicha maldita,/De tudo me dá o troco/E eu vivo na desdita/De ser lúcido e ser louco”. (BUARQUE;GUERRA, 1974, P. 11).

125 "Mário - E a apresentação dos heróis, e tudo isso. Quer dizer, tinha a ideia original que era em cima da nota de 500 cruzeiros. Era baseada na nota de 500 cruzeiros.

Fernando - Verdade. Que era o brasileiro, o índio e o negro”. (PEIXOTO; MASETTI, 1973). 
Nossa forma de arte popular está na revista, no circo, na chanchada da Atlântida, na verborragia do baiano, na violência de tudo o que recalcamos, na violência do nosso inconsciente. É isso que temos que devorar e esculhambar. É desse material que é feito o país: plumas e recalques. (CORRÊA, 1998, p. 105).

A provável diferença entre a estética de Zé Celso e a de Calabar é que aqui esse modelo de representação popular e comercial era utilizado para tornar risíveis os “heróis”, e não incorporado em tom festivo. A operação tropicalista de sobrepor contradições sem chegar a uma síntese ${ }^{126}$ desagradava a Peixoto, e possivelmente também não agradava aos dramaturgos de Calabar. Vimos como desde o Rei da Vela Peixoto admirava a potência de um antropofagismo cultural, mas se incomodava com os rumos do movimento. A cultura de consumo e a burguesia teriam consumido um “tropicalismo” esvaziado de conteúdos revolucionários (PEIXOTO, 2002, p. 185). Para que a estética da Atlântida fizesse sentido em Calabar, ela teria de vir à serviço da crítica social.

A cena que ridiculariza os “heróis” era acentuada pela canção de Chico e Guerra. Ao mencionar a importância da música para o efeito cômico, Peixoto ainda descreve: "Sobretudo o jeito que o Flávio ${ }^{127}$ cantava, era uma forma mais brechtiana de cantar, ele quebrava a música no meio, que é um sambão” (1973). A crítica veiculada pela musicalidade do samba em atrito com o texto violento era reforçada pela interpretação do ator. A referência a Brecht indica a importância da direção de Peixoto para o trabalho de atuação. Em suma: dramaturgos, compositor, diretor e ator trabalhavam juntos. E aqui o seu trabalho estava em torno de um debate sobre os heróis nacionais - tema importante para o Teatro de Arena na década anterior, como vimos, e que nessa cena aparece em chave negativa. Os heróis da História oficial brasileira são representados por três personagens que se curvaram aos interesses do colonizador. O único herói potencialmente positivo da peça é o próprio Calabar, que só surge em cena para ser morto: um herói ausente.

Finda a canção os três “heróis” sentam-se à mesa com Mathias de Albuquerque e o Frei, e planejam a batalha de Porto Calvo, na qual pretendem capturar Calabar. ${ }^{128}$. O

\footnotetext{
126 Uma análise aprofundada dessa característica da Tropicália foi feita por Roberto Schwarz. SCHWARZ, Roberto. Cultura e política, 1964-69. In O pai de família e outros estudos. Rio de Janeiro: Paz e Terra, 1978.

127 Flávio São-Tiago era o ator que interpretava Sebastião Souto na encenação de 1973. Ele também participou da primeira montagem de Roda Viva (texto de Chico Buarque e direção de Zé Celso), em 1968. ${ }^{128}$ Peixoto anota em seu texto: “Comer muito” (BUARQUE; GUERRA, 1973b). O encenador visualizava maneiras de reforçar cenicamente o retrato dos poderosos. É possível que também tivesse em mente a
} 
governante Mathias canta Fado Tropical. A escolha de gênero musical é relevante: embora seja reconhecido como um gênero português, historiadores afirmam que o fado surgiu primeiro no Brasil colônia ${ }^{129}$. O sentimentalismo do fado ajuda a constituir a ironia da canção, que desenha o sonho colonizador de o Brasil tornar-se um "imenso Portugal”. Entre uma estrofe e outra, declamações de Mathias aprofundam a violência da colonização: "Mesmo quando as minhas mãos estão ocupadas em torturar, esganar, trucidar, meu coração fecha os olhos e, sinceramente, chora”. (BUARQUE e GUERRA, 1974, p. 14). Segue em pauta a questão: quem narra a História? Aqui se trata de um colonizador que frisa não o sofrimento do torturado, mas as lágrimas do torturador.

Na fita da conversa sobre o espetáculo, Peixoto se pergunta sobre essa cena. Pensa que com o tempo poderia "dinamizar a cena no sentido de se mostrar o acampamento se preparando para atacar". Ao mesmo tempo, afirma que a cena "ficava parada de propósito. Eu acho que naquele momento o negócio era parar para ver a canção, e para ouvir a canção, e ver a letra” (1973). Mesmo após a censura, o encenador registra uma dúvida inerente ao processo criativo. A ideia de incluir o acampamento está muito ligada à sua proposta de radicalizar a presença do Povo, sobre a qual falaremos. Ao mesmo tempo, fazia sentido para o diretor dar a ver a canção, construir o foco para a letra, privilegiando a dramaturgia e suspendendo ações paralelas e ruídos de cena.

Finda a canção ocorre a cena da latrina, em que Mathias e um Holandês negociam a rendição de Porto Calvo enquanto defecam. Fica claro que os portugueses foram vitoriosos na batalha, e Mathias exige que Calabar lhe seja entregue. O holandês entrega Calabar “à mercê del Rey Dom Felipe de Castela”. O gesto é provocativo, pois lembra ao oponente que Portugal estava à época sob o domínio do monarca espanhol. No dia 5 de Agosto de 1973 Peixoto escreveu em seu caderno de direção sobre a necessidade de reduzir a cena da latrina, tratada então em reunião com os dramaturgos. Comparando a primeira versão do texto com a versão publicada vemos que os cortes

peça A Vida de Galileu, de Bertolt Brecht. Um dos traços gestuais contraditórios do personagem Galileu criado por Brecht era o fato de comer muito (mesmo sem ser especialmente interessado em manter os alunos que garantiam seu sustento, como é exposto no início da peça).

129 É possível que Chico Buarque e Ruy Guerra tenham aprendido isso com o pai de Chico, Sérgio Buarque de Holanda, que contribuiu para a fase de pesquisas que precedeu a escrita da peça. Em seu livro Cobra de Vidro ele afirma sobre o Fado: "Essa expressão, hoje típica da alma portuguesa, foi originalmente tão nossa como o velho lundum ou o cateretê. O fato parece bem documentado, principalmente depois das eruditas investigações do sr. Mário de Andrade” (BUARQUE, 1944, p. 77). 
foram mínimos. Talvez os dramaturgos não tenham concordado com a proposta de tornar a cena mais curta.

Após a censura, o diretor diz a Masetti que ainda considerava a cena "meio longa”, e que ela "era crítica por si mesmo. O fato de ser uma reunião de estadistas discutindo a paz sentados na latrina já diz tudo que se quer dizer. Em cima disso tinha que criar ritmo, vivacidade, passar a ideia de que enquanto se caga está se decidindo a sorte do cara.” (PEIXOTO, 1973).

Essa fala fornece alguns dados. Primeiro, de que a criticidade da cena era rapidamente transmitida pela situação (poderosos decidem o destino de um homem enquanto defecam). A situação risível e cruel era mais importante do que as piadas verbais. Por isso, segundo a avaliação de Peixoto, teria sido possível fazer mais cortes no texto. O segundo dado é que essa cena estava sendo pensada em função da proposta dramatúrgica. A dramaturgia já “era crítica”, já “dizia tudo”. O problema teatral era como transmitir de forma mais eficiente o que o texto propunha. E não se tratava de um problema menor! Para solucioná-lo, Peixoto faz referência ao Teatro de Revista e Masetti à esquetes de televisão - modelos em que uma cena cômica possui autonomia em relação ao todo de uma obra. Peixoto ainda reforça a necessidade de desbunde ${ }^{130}$ e de esculhambação (PEIXOTO; MASETTI, 1973). Tudo isso para gerar o efeito cômico e crítico esperado.

Terminada a cena da latrina entram em cena os “heróis” Souto, Camarão e Dias junto a outros soldados do exército português, que comemoram a vitória e trazem despojos de guerra - entre eles, Anna de Amsterdam. Mathias expressa seu incômodo com o domínio espanhol: "Portugal e Espanha estão unidos pela dinastia dos Felipes, está certo. Mas eu sou brasileiro, de sangue nobre português. E quem manda no Brasil ainda é Portugal e não a Espanha” (BUARQUE; GUERRA, 1974, p. 24). Fernando

\footnotetext{
${ }^{130}$ Peixoto utiliza quatro vezes o termo "desbunde" em seu diálogo com Masetti. A palavra possui diversos significados: pode se referir a um efeito de deslumbramento; a um estado de confusão ou espanto; e ainda, como vimos, à vivência da contracultura no Brasil. No trecho mencionado acima, a palavra aparece ao lado de "esculhambação". Veremos mais adiante como Peixoto também associa desbunde a ironia. Já Mário Masetti diz sobre uma cena que ela "devia ter um desbunde muito engraçado" (1973).

Nas falas de Peixoto e de Masetti, "desbunde" se relaciona ao campo estético. Parece se referir a um recurso possível para fazer rir e alimentar o pensamento crítico dos espectadores. De todo o modo, a escolha da palavra está ligada àquele momento histórico, em que “desbunde” também era uma forma de contestação dos costumes sociais.
} 
Peixoto analisa: "Mathias na opção brasileira: Castela sim; Castela não"131. Ele se refere ao Reino de Castela, região histórica espanhola. Os esforços de Mathias e de seu exército estavam realmente favorecendo a Espanha. Essa submissão o incomodava, mas a colonização portuguesa era para ele natural.

A crítica de Calabar publicada na revista francesa Travail Théâtral esclarece: “na verdade, acentua Fernando Peixoto, (...) naquele momento histórico não existiam possibilidades de uma opção brasileira - trava-se uma batalha entre Portugal e Holanda, dilacerando o solo brasileiro no saque do açúcar e dos engenhos do Nordeste”132. Veremos mais adiante como Peixoto lança mão do coro para ampliar o debate sobre uma “opção brasileira” verdadeiramente ligada aos interesses nacionais. Uma “opção brasileira" que, superando o contexto ficcional do século XVII, se ligasse às perspectivas políticas dos brasileiros da década de 1970 .

Há um debate entre os personagens sobre o que é ser traidor: é traidor quem trai a Holanda? Castela? Portugal? Jesus Cristo? Peixoto observa: "Na dramaturgia moderna, Brecht, mais do que ninguém, desmistificou de forma irreversível o conceito de herói. Em Calabar (...) Ruy Guerra e Chico Buarque de Holanda desmistificam, com inteligência e sensibilidade, o conceito de traidor" (PEIXOTO, 1989c, p. 152). O fato é que eliminar um homem rotulado como "traidor" traz capital político. Mathias condena Calabar para marcar seu nome na História, e manda o Frei ir confessá-lo. Afirma seu poder dizendo que "neste Pernambuco eu sou Dom Felipe de Castela, rei de Portugal e Algarves”, ao que Anna responde com uma canção em que se apresenta. Masetti resumiu a ironia deste momento: "Se você é dono de Portugal, Porto Calvo... E ela dizendo: "E daí?! Sou Anna de Amsterdã”” (1973). Anna “Da compra, da venda, das trocas, das pernas” (BUARQUE; GUERRA, 1974, p. 27), Anna prostituta.

O Frei traz notícias sobre a confissão de Calabar. Mathias espera que tenham sido revelados nomes de outros traidores, uma possível referência às práticas do regime militar de torturar perseguidos políticos em busca de novos alvos. Mas o Frei alerta: “os grandes culpados não estão na arraia-miúda”, frase grifada por Peixoto em seu texto (BUARQUE; GUERRA, 1973b).. “Arraia-miúda” é uma maneira de chamar ao povo, à

\footnotetext{
${ }^{131}$ Em seu primeiro estudo da dramaturgia, Fernando Peixoto circula uma referência a "Castela” presente na dramaturgia e escreve "Espanha". No contexto do texto "Castela" e "Espanha" funcionam quase como sinônimos. (BUARQUE; GUERRA, 1973b).

${ }^{132}$ CALABAR interdit - tradução do texto publicado em "Travail Théâtral”. Travail Théâtral, Paris, primavera, 1974. Disponível em: <http://chicobuarque.com.br/critica/crit_calabar_travail.htm>. Acesso em: mar. 2019.
} 
massa despossuída ${ }^{133}$. Ou seja: o Frei avisa que existem traidores poderosos, com os quais seria aconselhável não gerar enfrentamento político.

No momento em que os dois se encaminham para um canto escuro para seguir confabulando, segundo a rubrica, “os moradores entoam o refrão do Miserere Nobis”. A mesma reza que abre o espetáculo é aqui retomada pelo coro de 28 atores. É deste coro em oração que Bárbara, mulher do condenado, se destaca. Nessa cena o povo se faz presente, mas não chega a agir: não intervém em prol de Calabar. A fala versificada de Bárbara se dá sobre o som da reza - aqui os dramaturgos já pensavam na sonoplastia, produzindo sentidos através da sobreposição de texto individual e canto coletivo. Ao longo dos versos Peixoto rascunhou, na primeira versão da dramaturgia, uma variação entre a reza, o silêncio e a boca chiusa, (termo em italiano que se refere a cantar com a boca fechada, fazendo soar a melodia sem dizer a letra). Essa variação contribuiria para destacar trechos do texto, fazendo do canto coral uma cama que acompanharia a personagem em seu desabafo.

O texto de Bárbara tematiza exatamente o imobilismo do povo: “Arraia-miúda não muda / Arraia-miúda está muda”. Em seguida e ainda em versos, ela fala de como é útil a um regime possuir um "traidor dentro da manga”. E que "O melhor traidor é o que se escala/ Corpo pronto para bala/ Se encurrala, se apunhala”. Possivelmente o trecho fazia referência às recentes iniciativas de guerrilha no Brasil, que em 1973 já haviam sido fortemente reprimidas. Parte da esquerda organizada (incluindo o Partido Comunista, PCB) fez duras críticas ao uso de táticas de guerrilha no contexto brasileiro daquele momento, por avaliar que não havia então condições de resistir militarmente ao Regime. Poeticamente, os corpos estariam se escalando prontos para bala. A fala é finalizada com imagens fortes de tortura e assassinato deste "traidor útil”. Horrores que estariam sendo ignorados pelo povo (aquele povo que, segundo a dramaturgia, seguia rezando): "E cabe dentro da mala / Se despeja numa vala. / Se esquece espetado em tala / Com que arraia não se rala / E não se fala na sala” (BUARQUE; GUERRA, 1974, p. 30-31). Veremos mais adiante como essa cena foi modificada pelo trabalho do encenador com o coro.

Uma mudança de luz indicada na rubrica transfere a cena para um diálogo entre Mathias e o Frei. Na dramaturgia original havia uma indicação de que o Miserere aos

133 Arraia-miúda tornou-se também uma maneira carinhosa de se referir aos atores do coro durante os ensaios, conforme Mário Masetti relatou em entrevista: "O elenco de apoio que a gente chamava de arraia-miúda, porque tem um trecho na peça que usa essa expressão”. MASETTI, Mário. Entrevista sobre Calabar. Entrevistadora: Nina Hotimsky. São Paulo, nov. 2016. 
poucos seria transformado pelos moradores no canto Cala a Boca Bárbara, canção que viria a seguir. Aqui Peixoto anotou: “trocar a canção por Tatuagem?” (BUARQUE;GUERRA, 1973b), substituição que de fato foi feita. A troca favoreceu o dado mortuário da canção Tatuagem. No entanto, a proposta inicial de transformar gradualmente uma reza em um canto de proteção à Bárbara (proteção que só se concretizaria através de um silêncio omisso) foi perdida com a alteração na ordem das canções.

O entrevistado Anselmo Vasconcelos foi quem chamou a atenção para o gesto de defesa implicado no "Cala a boca” do coro, que com a mudança era cantado no início da peça. Perguntado se havia violência na ordem de calar Bárbara, ele respondeu: "Não! Ao contrário. Era: [Cochicha cantando] "Cala a boca, Bárbara”. Era pra ela segurar a onda! Ela estava dando detalhe. Tinha os soldados, entendeu? Era para ela não dançar também, como ele dançou. Foi preso” ${ }^{134}$. O clamor coletivo para que Bárbara se expusesse menos teria um fundamento pragmático, de autopreservação. Ainda mais em tempos de Regime Militar, quando pessoas que se colocavam publicamente estavam sendo desaparecidas e mortas. No entanto, a reza transformada em imperativo de silêncio provavelmente constituiria um povo menos aguerrido do que o desejado por Fernando Peixoto, e a dramaturgia foi modificada.

Tematicamente o atrito entre religiosidade e conflitos materiais se manteve. Neste ponto Mathias faz sua confissão ao Frei: admite seu amor ao Brasil, que por vezes o fez hesitar em privilegiar os interesses da coroa portuguesa. Deseja "que Deus e os homens” o perdoem, ao que o Frei afirma: “Deus certamente perdoa”. O povo (sempre presente no discurso teatral através do coro) talvez não perdoasse... Mas Mathias já anuncia a um oficial: “podem dar início a execução” (BUARQUE; GUERRA, 1974, p. 32).

Após essa ordem, “subitamente iluminada, Bárbara canta Tatuagem" (BUARQUE; GUERRA, 1974, p. 32). Depois de uma cena irônica e farsesca entre o Frei e Mathias, a canção opera uma quebra brusca. Bárbara derrama um lirismo radical. A introdução executada por um instrumento de metal (que podemos escutar no disco Chico Canta, e que muito provavelmente entraria como playback no espetáculo) é bastante curta, já que a letra expressa urgência, mas traz em si um dado musical que permanecerá ao longo da melodia. Trata-se do trabalho com a escala cromática: já na

${ }^{134}$ VASCONCELOS, Anselmo. Entrevista sobre Calabar. Entrevistadora: Nina Hotimsky. São Paulo, jul. 2017. 
introdução uma sequência simples de notas é variada através da alternância entre o mi e o mi bemol ${ }^{135}$. A tonalidade da música está em dó maior, mas a presença do mi bemol sugere o tom menor, o que colabora para gerar uma sensação de melancolia.

Durante toda a música o intervalo de meio tom é explorado repetidamente, em diferentes alturas, através do uso da escala cromática. O semitom é a menor distância entre duas notas admitida na música ocidental. É o grau máximo de aproximação a que podem chegar dois sons com alturas diferentes. Bárbara canta que deseja ficar "como tatuagem” na pele do homem amado. Letra e melodia convergem ${ }^{136}$ para a imagem da menor distância possível entre dois corpos, característica do amor erótico. Isso, em um momento da fábula em que a morte de Calabar irá concretamente separar os corpos dos amantes.

A canção Tatuagem foi interpretada em diversas gravações ${ }^{137}$, e ganhou autonomia em relação à peça. No contexto do espetáculo seu sentido é mortuário: o eu lírico deseja ficar "feito tatuagem” no corpo de um homem que será enforcado dali a minutos. Ela deseja lhe dar “coragem / Pra seguir viagem / Quando a noite vem”. A viagem na noite, aqui, é a morte. Esse trecho da letra coincide musicalmente com a repetição de uma só nota. Mais uma vez a melodia reforça o sentido das palavras retrata a morte como ausência de movimento. Na partitura a repetição de uma mesma nota gera um desenho horizontal, como o de um corpo no chão.

A segunda estrofe alude repetidamente à imagem da fadiga, com palavras como exaustos, frouxa, murcha, farta, morta de cansaço. Frequentemente dizemos de alguém ao morrer que ele “descansou”. Por outro lado, podemos tecer uma relação com o contexto histórico: o início da década de 1970 no Brasil estava marcado pela sensação de esgotamento da luta. Quem havia escolhido se opor ao regime oficial, como foi o caso de Calabar, estava ou morto ou exausto. Apenas para citar dois exemplos muito próximos a Peixoto, Augusto Boal e Zé Celso haviam muito recentemente sobrevivido a prisões e tortura e partido para o exílio.

\footnotetext{
135 Consultamos a partitura que consta no Songbook de Chico Buarque. A mesma nota está grafada na introdução como mi bemol, e no restante da melodia como ré sustenido. CHEDIAK, Almir. Chico Buarque - Songbook volume 4. Rio de Janeiro: Lumiar, 2010.

${ }^{136}$ Devo essa preciosa observação ao professor Walter Garcia, que no exame de qualificação deste trabalho analisou a canção Tatuagem sob esse viés. Fica aqui o meu agradecimento ao professor.

${ }^{137}$ Em 1973 Maria Bethânia gravou a canção em seu disco Drama - $3^{\circ}$ ato. Seu arranjo manteve dados incômodos - como um constante reco-reco e uma letra entoada com o exagero das consoantes. Mas a interpretação mais conhecida da canção é a de Elis Regina, presente no álbum de 1976 Falso Brilhante. A versão de Elis colaborou para afastar a canção do sentido mortuário que tinha originalmente, em relação com a dramaturgia. Deslocada de seu contexto teatral, Tatuagem pode ser interpretada como mais uma das belas canções de amor de Chico Buarque.
} 
A última estrofe da canção começa com a imagem da cruz, que relaciona Calabar com a figura de um mártir. Assim como Jesus Cristo, certos traidores "morrem por nós”. A letra faz menção ao esquartejamento ao qual Calabar seria em seguida condenado: “Te retalha em postas / Mas no fundo gostas / Quando a noite vem”. A afirmação de que haveria um gosto pela flagelação gera uma camada de contradição. Como vimos (e na visão de Bárbara) o herói escolheu se escalar, “Corpo pronto para bala”. Mas a mulher deseja seguir no corpo dele: “Quero ser a cicatriz risonha e corrosiva”, canta ela (BUARQUE; GUERRA, 1974, p. 33).

Que uma cicatriz possa rir e corroer ao mesmo tempo é mais um dado de contradição potente da letra. Musicalmente, uma das maneiras pelas quais essa oposição se expressa é pelo trabalho com a escala cromática, que em contato com a harmonia gera acordes cheios de tensões. Além disso, os semitons na melodia tornam Tatuagem uma canção difícil de ser entoada - não por exigir grande extensão vocal, agudos e graves virtuosos, mas por exigir a precisão dedicada de quem narra uma história espinhosa $^{138}$

Pode-se dizer que toda a dramaturgia de Calabar busca ser uma cicatriz risonha e corrosiva. Tem momentos de ironia farsesca (como o de Mathias pedindo perdão por amar o Brasil) intercalados a canções tristes e ácidas (como Tatuagem). Materialmente falando, o teatro crítico brasileiro do início da década de 1970 talvez se assemelhasse a essa mesma imagem. Os artistas, apartados do povo (cujos movimentos sociais haviam sido massacrados), castrados pela censura e pelas ameaças de prisão ou exílio, não conseguiam desferir golpes concretos no Regime. Podiam, na melhor das hipóteses, ridicularizar e fazer arder o corpo social.

À canção se segue um novo corte brusco operado sonoramente. A rubrica indica: "Rufar de tambores. Em claro-escuro, soldados trazem um homem num cerimonial de execução. Oficial lê a sentença entrecortada por rufos de tambor” (BUARQUE; GUERRA, 1974, p. 33). Esse é o único momento em que o personagem Calabar apareceria fisicamente no palco. Mas a opção dos autores indicada na rubrica é deixá-lo

\footnotetext{
138 O trabalho de Chico Buarque com cromatismos e com acordes repletos de tensão foi em parte herdado da Bossa Nova. É fato que muitas das letras da Bossa Nova não possuem letras com conteúdos trágicos ou mortuários. A complexidade harmônica das canções da Bossa Nova muitas vezes (mas não sempre!) é palco de letras líricas, amorosas, lúdicas. Uma análise que articula tensões harmônicas com tensões temáticas (presentes na letra de uma canção) não pode ser generalizada. No caso de Calabar, seu sentido se constrói na relação entre música, letra e dramaturgia.

Há todo um debate sobre os sentidos sociais da Bossa Nova. Duas visões importantes sobre o assunto são as de Lorenzo Mammì (1992) e a de Walter Garcia (2012).
} 
na penumbra. Como sugeriu Ruy Guerra (2017), a opção foi por criar um herói sem rosto. A sentença em muito se assemelha à de Tiradentes, herói contado pelo Arena na década anterior. Ordena que o corpo de Calabar seja esquartejado, a casa derrubada, seu chão salgado, seus bens confiscados e seus descendentes declarados infames até a quinta geração, “para que não perdurem na memória” (BUARQUE; GUERRA, 1974, p. 34). Não bastava matar o homem, era preciso matar a memória de sua luta.

Finda a leitura da sentença, a rubrica indica o fundo orquestral de Cobra de Vidro. Essa canção só será cantada por Bárbara quase ao final da peça, logo antes de Mauricio de Nassau deixar as terras brasileiras. No ponto em que estamos, os espectadores ainda não teriam conhecido sua letra. A musicalidade de Cobra de Vidro falaria por si só. Este é, aliás, um procedimento constante da dramaturgia de Calabar: sugerir o fundo instrumental de determinada canção para um momento em que ela não é cantada. O contrário também ocorre: que trechos de letras sejam faladas, antes ou depois de aparecerem enquanto canção. Esse tipo de procedimento é bastante comum no teatro musical em geral (e pode ser relacionado ao leitmotiv de Wagner ${ }^{139}$ ), mas vale observar como aparece nesse espetáculo específico.

A letra do refrão de Cobra de Vidro, que diz apenas "presta atenção”, quase pode ser intuída em uma versão instrumental. A música é tensa todo o tempo. Essa tensão envolve o diálogo entre os “três heróis" (Souto, Dias e Camarão), três soldados que já lutaram junto com Calabar. Na conversa são anunciadas frases que irão mais tarde compor a letra da canção Cuidado. As frases são: “não vi nada”; “ninguém diz nada”; “não sei mais nada”. (BUARQUE; GUERRA, 1974, p. 34).

Em um primeiro momento do diálogo eles naturalizam a execução que virá. Dias diz que “A guerra tem todos os direitos. (...) É natural. É a guerra”. A rubrica indica: “Bárbara parece não prestar atenção aos três guerreiros” (BUARQUE; GUERRA, 1974, p. 34). Os homens falam sobre ela, se perguntam se Bárbara já sabe sobre o destino do companheiro, e ela segue calada. O diálogo dos "heróis” por si só poderia soar inverossímil ou ingênuo; o requinte da canção instrumental e a presença calada de Bárbara geram contradição na cena.

Uma virada ocorre: "Bárbara parece despertar”, indica a rubrica, e apela aos guerreiros para que impeçam a execução. Peixoto anota neste trecho da dramaturgia:

${ }^{139}$ Leitmotiv é um termo em alemão que literalmente significa "motivo condutor". Essa técnica de composição foi formulada pelo alemão Richard Wagner em suas óperas. A ideia é que determinado tema ou melodia seja associado a uma personagem ou a um assunto. Assim, ao escutar um mesmo tema em diferentes situações, o espectador produz associações. Telenovelas e filmes utilizam muito esse recurso. 
"Bárbara quer saber tudo (interage com tudo)”; "Calma, ela quer saber: interrogando os três heróis, colocando-os na parede => enquanto Calabar é enforcado" (BUARQUE; GUERRA, 1973b, grifo do autor). Veremos que essa imagem de Bárbara interagindo com tudo foi expressa em cena através de uma marcação estilizada. Os três homens afirmam não ter nada com isso, e se utilizam de um argumento muito comum aos militares: “Cumprimos ordens superiores”. Essa pode ser uma menção aos militares que ficaram calados frente aos horrores do Regime instaurado em 1964. A cena também veicula uma discussão sobre a questão racial. Segundo Guerra:

Camarão era índio mesmo, era um tipo importante naquela época. O Dias era negro e, inclusive, foi um cara que serviu para atacar o Quilombo de Palmares, mais tarde. A Bárbara serve para colocar um pouco em questão os personagens. Ela remete os personagens para o que eles representam, em termos raciais, dentro de uma perspectiva moderna. O Dias, do ponto de vista atual, podia ser muito mais traidor do que o Calabar. A partir do momento em que é um negro que serve a uma série de atitudes de encaminhamento da repressão até o ponto de não ser mais negro, de recusar a negritude dele (GUERRA, 1973a, p. 14-20).

Os debates sobre o racismo seguiram se transformando desde a década de 1970. É possível que o movimento negro hoje formulasse essas questões de outro modo. De todo o modo, fica o registro da preocupação dos dramaturgos em incluir também um viés étnico ou racial no debate sobre a traição. Isso em um ponto crucial da ação dramática, logo antes da execução de Calabar. Um recurso dramatúrgico interessante é que Bárbara repete frases proferidas pelos soldados. O que é dito por eles para se redimir (talvez num registro de interpretação farsesco) assume na boca dela uma intensidade trágica: "Eles não têm nada com isso. Eles são apenas soldados. Agora é com o rei e o carrasco” (BUARQUE; GUERRA, 1974, p. 37).

Fernando Peixoto resumiu as falas dos três "heróis” na anotação: “Campo do não tenho nada com isso (isenção de responsabilidade)" (BUARQUE; GUERRA, 1973b). Na dramaturgia essa isenção se expressa em versos cantados pelos soldados ${ }^{140}$ que aludem à cegueira, surdez e mudez, preparando uma imagem que seria corporificada em seguida. A canção do “Não tenho nada com isso” é interrompida,

\footnotetext{
${ }^{140}$ Essa canção não foi gravada no disco Chico Canta, e nem em outros discos. Faz parte de um conjunto de músicas compostas tendo por finalidade servir à cena, que não ganharam autonomia enquanto canções. A título de exemplo, a primeira peça de Chico Buarque (Roda Viva, 1968) também inclui músicas que se encerraram naquele espetáculo, como o rock'n'roll paródico cantado por Ben Silver.
} 
segundo a rubrica, com o "rufo de tambor e morte de Calabar" (BUARQUE; GUERRA, 1974, p. 42). Os três personagens formam a imagem dos três macaquinhos de marfim, um cego (que cobre os olhos com as mãos), um surdo (que cobre as orelhas) e um mudo (com a boca tapada pelas próprias mãos).

Na primeira versão da dramaturgia havia uma descrição mais específica sobre como retratar a execução. Além do rufo do tambor, a rubrica previa "estrondo surdo que marca a queda do corpo de Calabar, que agora balança, na contra-luz” (BUARQUE; GUERRA, 1973b). O som e a luz construíam a cena, como é característico dos autores. No texto final publicado eles deixaram em aberto a maneira de retratar esse evento central, abrindo espaço para as escolhas de potenciais encenadores. É possível que o próprio Fernando Peixoto tenha feito essa sugestão.

Logo após a morte de Calabar e a formação cênica dos três macaquinhos imobilizados, Bárbara entoa a canção Cuidado. Ela retoma frases ditas pelos “heróis”, inclusive durante o tempo em que Bárbara “parece não prestar atenção” neles. Enquanto a personagem se mantinha calada, ela articulava o que agora expressa: "Ninguém sabe de nada/ Ninguém viu nada / Ninguém fez nada”. Relaciona então essa inação com a metáfora dos macaquinhos de marfim, porém agrega peso à imagem ao inserir a ideia da castração, que fecha a letra: "Você / Seu ventre inchado / Ainda vai gerar / Um fruto errado. / Um bonequinho / Um macaquinho de marfim, / Castrado"141 (BUARQUE; GUERRA, 1974, p. 43).

Essa música também não entrou no disco, mas foi reaproveitada por Chico Buarque em sua dramaturgia seguinte, Gota d’Água (uma tragédia carioca baseada em Medeia, escrita em parceria com Paulo Pontes, que estreou em 1975). Masetti revelou em entrevista que a música da canção Basta um dia é a mesma música de Cuidado ${ }^{142}$. Entre as duas letras ${ }^{143}$, a que se canonizou foi a de Basta um dia, pois o espetáculo Gota d’Água permaneceu cinco anos em cartaz e gerou o seu próprio disco, com a

\footnotetext{
${ }^{141}$ A letra completa da canção é a seguinte: "Ninguém sabe de nada /Ninguém viu nada / Ninguém fez nada / Ninguém é culpado / Bichos de estimação / Nesse jardim / Cuidado / Estão todos gordos / Sempre cem por cento cegos / Cem por cento surdo-mudos / Cem por cento sem perceber / A agonia / Da luz / Do dia / Você / Seu ventre inchado / Ainda vai gerar / Um fruto errado / Um bonequinho / Um macaquinho de marfim / Castrado" (BUARQUE; GUERRA, 1974, p. 42-3).

${ }^{142}$ Essa correspondência também foi apontada por Wagner Homem em seu livro "Histórias de canções: Chico Buarque”.

${ }^{143}$ Os únicos versos comuns às duas letras (e colocados musicalmente no mesmo trecho de suspensão, que se segue ao momento de maior aceleração rítmica) são: "Da luz/ Do dia”. Em Cuidado, estão todos "sempre cem por cento cegos / cem por cento surdo-mudos / cem por cento sem perceber / A agonia / Da luz / Do dia". Em Basta um dia, "se beija, se maltrata / Se come e se mata / Se arremata, se acata e se trata / A dor /Na orgia/ Da luz do dia".
} 
interpretação da atriz e cantora Bibi Ferreira. Não faria sentido se utilizar da mesma melodia para gravar Cuidado, tampouco interpretá-la em shows descolados do contexto dramatúrgico para o qual foi composta. Cuidado foi inclusive excluída do Calabar de 1980, quando a dramaturgia foi revista pelos autores em parceria com Fernando Peixoto.

Uma comparação mais aprofundada entre as duas letras ficará para uma próxima ocasião. Vale observar que ambas são cantadas por personagens femininas vivendo situações limite ${ }^{144}$, e ambas as letras trazem uma espécie de maldição. A de Gota d’Água, mais dramática, e a de Calabar mais narrativa, épica. A trágica Joana de Gota d’Água precisa lidar com sua dor em ação. Para isso matará os filhos e irá se suicidar. Bárbara seguirá a peça toda chamando atenção para a cegueira, surdez e emudecimento coletivos, mas não será ela a resolver o problema ou evitar a castração anunciada. A responsabilidade final do conflito exposto em Calabar fica com os espectadores. E a sanidade, nos tempos de Calabar como na década de 1970, parecia caminhar junto com a traição.

Quando acaba de cantar, Bárbara "remexe o sangue de Calabar numa bacia num gesto caseiro” (BUARQUE; GUERRA, 1974, p. 43). A dramaturgia aponta para um efeito grotesco. Sobrepõe uma atividade cotidiana e o horror de lidar com os restos mortais de um amor que foi executado. Peixoto intitula a cena de " $\mathrm{O}$ sangue e o corpo de Calabar (a comunhão)”. O encenador faz menção ao simbolismo cristão, já presente na letra de Tatuagem através da imagem da cruz. Ele descreve: “Bárbara mexe no sangue e no corpo de Calabar, diz que ele está vivo (...). Anna aproxima-se dela com amor. Ambas estão unidas pelo sangue de Calabar” (BUARQUE; GUERRA, 1973b). A insistência de Bárbara em afirmar que Calabar está vivo está ligada ao tema da memória. "Eles não são capazes de o matar", diz ela. "Eles” - os inimigos, os colonizadores, os poderosos - não conseguiriam mata-lo enquanto Bárbara não o esquecesse. Anna lhe propõe amor e cuidado, e as duas cantam Anna e Bárbara ${ }^{145}$. Há uma rubrica desafiadora para a atriz que interpretasse Bárbara: “Anna canta para Bárbara e Bárbara canta para Calabar, mas Calabar nesse momento tem o rosto de

\footnotetext{
${ }^{144}$ Vimos que Bárbara canta Cuidado logo após a execução de seu amado. Já a Joana de Gota d' Água canta Basta um dia no momento em que consegue um dia a mais para ficar na Vila do Meio-Dia, e decide que será tempo suficiente para operar sua vingança: "Um dia pra aplacar /Minha agonia / Toda a sangria / Todo o veneno / De um pequeno dia”. (BUARQUE; PONTES, 1975, p. 151).

145 Gravada em alguns álbuns sob o nome de Bárbara.
} 
Anna” (BUARQUE; GUERRA, 1974, p. 46). A rubrica tenta dar conta dessa transição delicada, em que a viúva do enforcado se envolve amorosamente com outra pessoa.

A presença de um casal homoafetivo era significativa naqueles tempos de moralismo violento. Segmentos da sociedade civil que eram reacionários, do ponto de vista dos costumes, por vezes eram os mesmos que apoiavam os horrores praticados pelos militares no poder. A defesa da família e das tradições cristãs nem sempre se expressava em uma defesa ampla dos direitos humanos ${ }^{146}$. No álbum Chico Canta a letra sofreu um corte devido à censura moral ${ }^{147}$.

Do ponto de vista da estrutura dramatúrgica, Peixoto (1973) via problemas na cena: considerava Anna uma personagem que chega "não se sabe de onde. É difícil a Anna entrar nessa cena. O início do relacionamento da Anna com a Bárbara não é preparado. Então a cena começa e termina nela mesma, é muito estranha. É uma cena difícil de ser feita, mas acho que ela estava sendo resolvida”. Essa é uma das poucas críticas de Peixoto ao texto que foi registrada na conversa com Masetti; o diretor assistente faz críticas à dramaturgia com mais frequência. Mesmo ao apontar um problema dramatúrgico, Peixoto o formula em termos de “estranheza” e "dificuldade” características com as quais era possível lidar ao trabalhar a cena.

Neste ponto dava-se um entreato, uma transição entre a primeira e a segunda parte do espetáculo. O trecho foi bastante modificado da primeira versão mimeografada até a dramaturgia definitiva publicada em 1973. Será descrita a estrutura do texto final, aquele que chegou a ser ensaiado. A rubrica indica que amanhece e Anna e Bárbara estão caídas. Entram soldados holandeses e Bárbara declara seu desprezo, "não sei se pela ingratidão, pela covardia ou pelo fingimento dos mortais” (BUARQUE; GUERRA, 1974, p. 47).

\footnotetext{
146 Ao mesmo tempo, à época, certos setores da Igreja (especialmente os ligados à Teologia da Libertação) eram essenciais na defesa dos direitos humanos. Freis ligados a essa corrente estão entre os militantes que foram presos, torturados e mortos pelo Regime Civil-Militar.

Infelizmente, segue muito atual a coincidência entre discursos moralistas e religiosos e práticas que violam os direitos humanos básicos.

${ }^{147}$ A frase "E mergulhar no poço escuro / De nós duas" teve a palavra "duas" cortada. Era uma palavra que explicitava o fato de a canção de amor se dar entre duas mulheres. Como o nome "Anna” não é mencionado na letra, um ouvinte descontextualizado do espetáculo poderia considerar que a canção era de um eu lírico masculino para sua amada Bárbara. A frase "Sabendo que no fim da noite / Serei tua" também define o gênero feminino de quem canta, mas pode ser interpretada como uma resposta de Bárbara a quem cantasse para ela (fosse um homem ou uma mulher).

Essa canção foi anteriormente gravada no álbum Caetano e Chico juntos e ao vivo, de 1972. A mesma palavra "duas" foi censurada, encoberta por aplausos da plateia (já que o disco foi gravado a partir de um show ao vivo).
} 
Chega então Maurício de Nassau, enviado pela Holanda como governador-geral a serviço da Companhia das Índias Ocidentais. Fica subentendido que os portugueses venceram a batalha de Porto Calvo, mas os holandeses conquistaram outras terras de Pernambuco, formando na região um “Brasil holandês”. Nassau é uma figura histórica extremamente contraditória. Peixoto escreveu longamente sobre seus feitos, em texto para o programa do espetáculo ${ }^{148}$. Segundo o diretor, Nassau assegura um momento de festa: "Em certo sentido, Nassau assume o sonho de Calabar: o utópico sonho de um país mais livre” (1989c, p. 155). Ao mesmo tempo, sua política de conciliação visa favorecer os lucros dos holandeses, e acaba por trair o sonho de Calabar (PEIXOTO, 1989c, p. 156).

Ao desembarcar no Brasil, Nassau declama um “estranho epitáfio” para Calabar: “Tu não morres em vão. / (...) repito-o, porém, deste meu porto/ como um grito de conforto / a algum estranho herói / de contorno incerto/ no porto de um povo de imaginação” (BUARQUE; GUERRA, 1974, p. 48).

O herói pode lhe ser estranho pelo desconhecimento, já que Nassau acaba de chegar ao país. Mas o herói é literalmente mostrado ao público com o contorno incerto: ele aparece em cena apenas no momento da execução, e a sugestão da rubrica é que ele surja “em claro-escuro”. Já a expressão “povo de imaginação” possui duas leituras possíveis. Pode-se entender que o povo dessas terras seria imaginativo, sonhador. Ou (e haja gravidade na constatação) pode-se ler que o povo brasileiro seria um povo imaginado, sem existência real.

Há um evidente anacronismo na menção a um povo brasileiro no século XVII ${ }^{149}$. Aqui se faz uma alusão a um debate caro aos artistas e intelectuais brasileiros de esquerda durante as décadas de 1950 e 1960. Marcelo Ridenti (2000) traz uma grande

\footnotetext{
148 Seguem algumas das observações de Peixoto sobre Nassau. É possível verificar o esforço de estudo histórico realizado pelo encenador: "Trazendo uma corte de artistas e cientistas, Nassau estabelece o choque entre o importado do humanismo renascentista europeu e o primitivo missioneirismo medieval encarnado pela Companhia de Jesus. Nassau transforma a paisagem e concilia os choques de classes. Estabelece a lei como igual para todos (...). Concede medidas de tratamento mais humano para os negros, organiza uma câmara com igual número de representantes holandeses e brasileiros, permite, dentro de medidas, a liberdade de culto: é preciso não esquecer que os protestantes são membros de seu governo e seus chefes, os católicos são os senhores de engenho, a produção, e os judeus representam o comércio, o capital. Por trás de uma política de conciliação aparentemente liberal existe o planejamento estudado de um estadista hábil: paz significa maior produção, maior produção significa maior lucro. Mas Nassau não se descuida também de ações militares, mantendo viva a guerra de conquista. Acaba, entretanto, destituído de seu posto, por suas próprias contradições” (PEIXOTO, 1989c, p. 155).

${ }^{149} \mathrm{O}$ próprio Peixoto esclarece esse ponto em texto que teria sido publicado no programa do espetáculo. Cita Barbosa Lima Sobrinho, que afirma: "no Brasil do século XVII não se encontraria ainda nenhum indício de consciência nacional brasileira” (SOBRINHO apud PEIXOTO, 1989c, p. 152).
} 
contribuição sobre o assunto, no livro "Em busca do povo brasileiro". Fazendo um paralelo entre o tempo ficcional da peça e a década de 1970, o questionamento poderia ser: Lamarca e os demais guerrilheiros morreram em vão? Ou, se morreram por seu povo, esse povo possui identidade e objetivos em comum? Essas questões serão retomadas adiante.

Apesar do peso desses questionamentos, Chico e Ruy inserem um coro na dramaturgia. Existem os moradores do Recife, os soldados, os fiéis católicos. A peça depende da presença dessas figuras anônimas, que sofrem as violências da colonização portuguesa, e experimentam algumas melhorias durante o governo de Nassau. Com ou sem consciência de classe, com ou sem identidade nacional, aquelas pessoas estão em cena e cantam. Neste momento, para comemorar a chegada de Nassau, os moradores cantam “Não existe pecado do lado de baixo do Equador”.

O frevo começa com um solo de Anna de Amsterdam, o que agrega contradição à letra. É uma prostituta que canta a inexistência do pecado; como mercadoria que é, precisa vender seus serviços para os novos clientes holandeses. Ela, que acabara de declarar seu amor por Bárbara, agora pede para um interlocutor genérico para ser jantada, abusada, para ser "escracho, capacho" (p. 50). A letra se baseia na frase em latim “ultraequinoxialem non pecar”, registrada pelo cronista Barlaeus em 1641 e citada por Sérgio Buarque de Holanda em seu Raízes do Brasil. Esse ditado era corrente na Europa do século XVII, pois para os colonizadores era "como se a linha que divide o mundo em dois hemisférios também separasse a virtude do vício” (BARLAEUS apud ROCHA, 2006, p. 131). Essa concepção produzia efeitos cruéis na maneira pela qual os europeus tratavam mulheres negras e indígenas no hemisfério Sul. No contexto de Calabar o ditado europeu é ironizado, ao ser cantado pelos moradores desse país em que todos os pecados seriam permitidos. Anna abre a canção, mas todo o coro passa a cantar e dançar o frevo enquanto o cenário é modificado (dado já previsto na dramaturgia através de uma rubrica).

Peixoto anota em seu texto uma proposta de divisão da letra entre o solo de Anna e o canto coletivo, e escreve "CORO” em caixa alta e letras garrafais ao lado de duas estrofes (BUARQUE; GUERRA, 1973b) ${ }^{150}$. O problema do povo brasileiro levantado pouco antes pela fala de Nassau provavelmente lhe provocava. Militante do Partido Comunista, interessado em construir um teatro nacional popular, Peixoto

\footnotetext{
${ }^{150}$ A imagem dessa página está disponível como anexo dessa dissertação (figura 2 - Anexo C).
} 
considerava a ideia de um “povo brasileiro” como fundamental para orientar sua criação artística. Mas trabalhava em um tempo de refluxo da luta política, e a partir de uma dramaturgia que lidava com as recentes derrotas. Dramaturgia pouco otimista, portanto. A presença do coro, do povo do Recife em cena, era um recurso fundamental para que Peixoto refletisse sobre o povo brasileiro da década de 1970 através da linguagem teatral. Figuras descoletivizadas, que compunham o painel social da peça, assumiam a forma coletivizada do coro.

Os moradores aparecem na cena seguinte dando "Vivas" a Nassau. Também se aproxima de Nassau um papagaio que só diz “Oba”, interjeição que era comum às vedetes do Teatro de Revista. Os membros do coro ao redor de Nassau comportam-se como o povo diante de um líder populista. A dramaturgia indica uma aproximação entre Nassau e Juscelino Kubitschek: o governador holandês propõe "realizar cinquenta anos em cinco” (BUARQUE; GUERRA, 1974, p. 52), em referência ao antigo presidente. Há na gestão de Nassau uma promessa de crescimento econômico que caminha ao lado do sonho de desenvolvimento científico e cultural. Chico Buarque afirmou à época que “Nassau era tropicalista (...) um pouco Chacrinha ${ }^{151}$, um pouco Juscelino” (BUARQUE; GUERRA, 1973a, p. 12 -13). A alusão a Chacrinha certamente foi aprofundada pela encenação, que enchia o palco de cores com a chegada do governante holandês.

Como é frequentemente sublinhado nas anotações de Peixoto, aspectos econômicos são centrais para a peça. Nassau desembarca em uma região que produz açúcar. O holandês promete favorecer o cultivo da cana-de-açúcar e os engenhos através da abertura de linhas de crédito e redução de impostos. Sua política econômica consiste em apoiar os produtores de açúcar para favorecer os holandeses que circulam a mercadoria.

Há também a promessa de modernizar a cidade do Recife, através da construção de uma ponte e de outras melhorias urbanísticas. Peixoto anota: "Nassau em cena - o séquito cultural-científico” (BUARQUE; GUERRA, 1973b). O holandês traz consigo pintores, astrônomos, arquitetos, naturalistas, médicos. Os Moradores comemoram, mas surge em cena a personagem do Consultor, um conselheiro oficial de Nassau. Ele está ali para controlar os gastos do governante e proteger os interesses da metrópole. O

\footnotetext{
${ }^{151}$ José Abelardo Barbosa de Medeiros, o Chacrinha, foi um comunicador de rádio e televisão brasileiro que fez muito sucesso, especialmente entre 1950 e 1980. Foi assumido pelos artistas da Tropicália como um símbolo pop. Na primeira peça escrita por Chico, Roda Viva, o cenógrafo e figurinista Flávio Império trabalhou com pessoas da equipe de Chacrinha. Isso porque a peça discutia o processo de mercantilização de um cantor, e a televisão cumpria um papel fundamental nesse processo.
} 
Consultor opina em assuntos políticos e econômicos; fala em nome da Holanda e da Companhia das Índias Ocidentais, grupo privado de mercadores holandeses interessado no comércio do açúcar. Mesmo os mais desenvolvimentistas dentre os governantes do Brasil sempre sofreram pressão estrangeira, de forma a garantir os lucros da Holanda (e em outros tempos de Portugal, da Inglaterra, dos Estados Unidos...).

A necessidade de Nassau enriquecer a Holanda torna a morte de Calabar mais triste, e menos heroica. A alegria "tropicalista" do governante, seu interesse pela beleza local, não o liberava de continuar com as guerras coloniais. A metrópole exigia conquistas territoriais, e não se importava com a quantidade de mortos que deixaria pelo caminho. Retomando mais um trecho do epitáfio que Nassau declama a Calabar:

Nassau (...) - duvido firmemente / em nome dos Santos Mártires, / que algum dia algum homem / tenha conhecido morte / que não fosse vã. Soldado 3 (segurando um pedaço de Calabar) - Também, era apenas um negro...

Nassau - Mas tu não morreste em vão. (BUARQUE; GUERRA, 1974, p. 49).

O comentário cruel do Soldado 3 - aliado à ação grotesca de segurar um pedaço do morto - evidencia a barbárie. Aqui fica clara a importância de um pequeno personagem para constituir o quadro social que envolve os protagonistas. As belas palavras de Nassau não encobrem a naturalização do horror. Um soldado holandês acha perfeitamente normal o assassinato de um homem negro. Se Calabar morreu por um Brasil holandês, ele possivelmente morreu em vão. Ou, no mínimo, morreu por um projeto política e economicamente contraditório - que assim como o governo de JK, compunha alas nacionalistas e alas “entreguistas”"152. No caso de Nassau, outra contradição constante era entre medidas humanistas e práticas militares colonialistas ${ }^{153}$. Se, ao contrário, a luta de Calabar estava em função de um projeto maior e a longo prazo, a dramaturgia não aponta para qualquer realização nesse sentido.

Dentre as melhorias de seu governo, Nassau promete a liberdade de culto no Brasil, e a construção de uma casa para o Frei vizinha ao Palácio. Vale lembrar que os holandeses eram predominantemente protestantes, e que no início da peça o Frei estava

\footnotetext{
$152 \mathrm{O}$ historiador Gorender afirma que "o Governo Kubitschek, afinal também eleito pelos comunistas, não era um governo de 'traição nacional', mas um governo de composição heterogênea, em que se defrontavam a ala nacionalista e a ala entreguista” (GORENDER apud MARTINS, 2007, p. 131).

${ }^{153} \mathrm{O}$ próprio personagem o afirma ao final da peça: "Eu continuo um homem de armas. E um humanista. E essa combinação é difícil em qualquer século” (BUARQUE; GUERRA, 1974, p. 92).
} 
alinhado aos portugueses católicos. Segundo Ruy Guerra, o Frei poderia representar a classe média brasileira ${ }^{154}$ - sempre hábil em tecer alianças com os poderosos com vistas em seu próprio benefício. Por fim, dois compromissos contrários são estabelecidos. Nassau promete ao povo uma era de paz, mas termina a cena anunciando um ataque à Bahia que visa à ampliação de seus domínios territoriais.

Nassau perde a batalha. Recebemos essa notícia através de Souto, que entra em cena para encontrar Bárbara. O soldado ajudou a derrotar os holandeses, mas mesmo assim pisa em seu território, pois está apaixonado por Bárbara. Após a canção Você vai me seguir ${ }^{155}$, os dois se amam. Mas a viúva termina rejeitando Souto e lembrando Calabar, com a canção Tira as mãos de mim.

Ao discutir com Peixoto sobre as dificuldades de ensaiar essa cena, Masetti (1973) fez uma crítica à dramaturgia: "Eu atribuo [a dificuldade] a um problema do texto, em que preparam para atacar a Bahia e existe um pulo. De uma cena para outra a Bahia já foi atacada. E realmente o Souto, o Flávio tinha que entrar com a responsabilidade de contar a derrota dos holandeses na Bahia”. Por um lado, dramaturgias de caráter épico frequentemente fazem "pulos” temporais e espaciais. As peças de Bertolt Brecht apresentam muitos saltos desse tipo. O teatro épico (ao contrário do Drama) não tem o compromisso de desenvolver um enredo linear, com encadeamento causal estrito. Por outro lado, um ator que entra em cena para viver uma situação amorosa pode encontrar dificuldades em contextualizar para o espectador acontecimentos bélicos. $\mathrm{O}$ ator teria de variar seu registro de interpretação, alternando duas tarefas: vivenciar a situação e narrar uma batalha. É esse o problema que Masetti levanta. Ele poderia ter sido resolvido com uma mudança textual, ou com um processo de ensaios mais longo, focado na formação de atores para um teatro épico brasileiro ${ }^{156}$.

Na cena de Souto e Bárbara se misturam o âmbito público e o privado. Por um lado, há o interesse de discutir a traição em diversos aspectos, o que inclui a traição entre amigos e a traição amorosa. Por outro lado, quando Bárbara rejeita Souto ela retoma sua luta por manter viva a memória de Calabar: "Pobre Sebastião, você não sabe o que é trair. Você não passa de um delator. (...) Calabar vomitou o que lhe enfiaram

\footnotetext{
154 “A representação da classe média a gente deu mais através do Frei”. GUERRA, Ruy. Entrevista sobre Calabar. Entrevistadora: Nina Hotimsky. São Paulo, mar. 2018.

${ }^{155}$ Essa canção não existia na primeira versão da dramaturgia, e foi a última a entrar no texto. Segundo rubrica da segunda versão dramatúrgica, a ideia original era que Você vai me seguir seria cantada como um contraponto de Tira as mãos de mim. (BUARQUE; GUERRA, 1973c).

${ }^{156}$ Peixoto expressou nas fitas sua preocupação com a falta de tempo de ensaios. Ele precisaria de mais tempo para formar atores na linguagem teatral que trabalhava. Voltaremos a esse tema mais adiante.
} 
pela goela. Foi essa a sua traição. A terra e não as sobras do rei. A terra e não a bandeira. Em vez da coroa, a terra” (BUARQUE; GUERRA, 1974, p. 63).

A primeira versão da dramaturgia incluía nessa cena uma carta escrita por Calabar antes de morrer, que Bárbara obrigava Souto a ler. A carta era uma declaração de princípios, uma tentativa de fazer com que o herói ausente deixasse claras as motivações de sua luta:

Depois de ter derramado o meu sangue pela causa da escravidão, passo para este campo, não como traidor, mas como patriota, porque vejo que os holandeses procuram implantar a liberdade no Brasil, enquanto os espanhóis e portugueses cada vez mais escravizam meu país (BUARQUE; GUERRA, 1973b).

Há algumas possíveis razões para esse trecho ter sido cortado. Uma delas é a opção dos dramaturgos em não transformar Calabar em um herói. Guerra afirmou à época:

Não há uma reabilitação de Calabar na peça, ele não passa a ser herói. O que há é uma discussão sobre o conceito de traição. (...) Nós achamos interessante não discutir o Calabar, porque a informação sobre Calabar é muito pouca. Nós não tínhamos nenhuma informação rigorosa que nos permitisse por o personagem em discussão, num nível que não fosse simplesmente o sentimental: é um traidor, então vamos colocar como herói (BUARQUE; GUERRA, 1973a, p. 6).

A carta esboçada na primeira versão fazia de Calabar um patriota morto pela liberdade. Um heroísmo tão explícito, e sem lastro nos documentos históricos pesquisados, desagradava aos dramaturgos. É possível também que a repetição do recurso da carta (já utilizado no início do primeiro ato para revelar a relação entre Mathias e Calabar) tenha causado incômodo, pois Peixoto anota: "Usar o texto da carta no início???????? (BUARQUE; GUERRA, 1973b)”. Ambas as cartas (a que permaneceu na dramaturgia e a que foi cortada) lidam com o desafio formal do herói ausente. Um herói - ou ainda, um traidor - que não entra em cena para falar das razões de sua luta, mas cuja luta interessa à peça. No segundo ato esse problema se agrava, pois além de ausente Calabar já foi morto.

Mesmo sem a leitura da carta, a cena entre Bárbara e Souto continha uma densidade política e amorosa difícil de ensaiar. Enquanto Masetti fazia críticas à dramaturgia, Peixoto direcionou suas preocupações para a própria encenação: “Essa 
cena não ganhou a grandiosidade que ela teria de ter no espetáculo. É uma cena que precisaria ser feita entre um rei e uma rainha. Não entre as personagens. Ela tinha uma grandeza shakespeariana, essa cena, que ela não foi atingida nunca” (1973).

William Shakespeare é mencionado três vezes por Peixoto em seu diálogo com Masetti ${ }^{157}$. Essa referência remonta aos estudos do encenador sobre o teatro épicodialético. Em seu livro "Brecht - uma introdução ao teatro dialético", ele explica como Brecht considerava Shakespeare um antecedente básico do teatro épico (no plano da dramaturgia) e um autor que só poderia ser representado "diante de espectadores que possuem sentido histórico” (BRECHT apud PEIXOTO, 1981, p. 76). Um autor que tanto interesse despertava em Brecht merecia a atenção de Fernando Peixoto.

A ideia de uma cena que se passaria entre um rei e uma rainha está ligada às peças históricas e tragédias shakespearianas. Nelas, os âmbitos público e privado se entrelaçam, na medida em que a vida pessoal dos governantes influi nas decisões políticas que afetam o reino. Masetti parecia se incomodar mais com essa mistura em Calabar $^{158}$ - talvez porque a relação de amor e ódio entre Souto e Bárbara não teria consequências reais na cidade do Recife.

Embora a cena como um todo apresentasse dificuldades durante os ensaios, a canção Tira as mãos de mim parecia encerrá-la bem. Peixoto diz que "Tira as mãos de mim era, sobretudo a parte final da Bárbara, a parte política mesmo da cena (1973)”. Sua letra possui um dado forte de teatralidade, é muito gestual. A relação de Bárbara com Souto e com Calabar é formulada em ação. Após deitar-se com Souto, ela pede que ele tire as mãos dela, e logo depois muda de ideia, ordenando "Põe as mãos em mim”. Bárbara não quer ser tocada para receber carinho, mas para explicitar a diferença entre Souto e o marido morto: "Vê se o fogo dele/ Guardado aqui / Te incendeia um pouco"; "E vê se a febre dele / Guardada aqui / Te contagia um pouco”. O verso final constitui uma espécie de vingança de Bárbara: “Tira as mãos de mim / Põe as mãos em mim / Vendeste um teu amigo / Até o fim / Agora leva o troco”159. (BUARQUE; GUERRA,

\footnotetext{
${ }^{157}$ A primeira referência é para explicitar um procedimento dos dramaturgos, que incluíram na cena da latrina uma citação a Otelo, mais especificamente do seguinte trecho: "Peço-vos por favor que em vossas cartas, ao relatardes estes tristes fatos, faleis de mim tal como sou, realmente, sem exagero algum, mas sem malícia". As duas outras referências utilizam "shakespeariano" como adjetivo, relacionado à necessidade de certas cenas ganharem em "grandeza" e "força".

${ }^{158}$ Analisando o segundo ato como um todo, Masetti (1973) volta ao assunto das cenas íntimas: "Tem três cenas muito compridas de dois atores só. Souto e Bárbara, Anna e Bárbara...”.

159 No caso da canção Tira as mãos de mim, há algumas diferenças entre a letra publicada na primeira edição de Calabar e as letras posteriormente gravadas. Uma delas é a exclusão da terceira estrofe, mais difícil de ganhar autonomia em relação à peça, pois fazia menção direta ao fato do interlocutor do eu
} 
1974, p. 64). Peixoto considerava que "a música era das coisas mais bonitas da peça” (1973). Esse é um dos casos em que uma canção composta como parte orgânica da dramaturgia favorecia o trabalho da encenação.

O texto volta a tratar do âmbito público, com a cena da Restauração. Peixoto e Masetti concordam que há ali “um pulo violento de época” (1973). Mais uma vez um salto temporal desafia a equipe de direção. Uma missa celebrada pelo Frei junto a um grupo de moradores católicos comemora a coroação de Dom João Quarto como rei de Portugal, livrando aquela nação do domínio espanhol. Nassau e um grupo de holandeses interrompem a missa, e Nassau apropria-se da pauta portuguesa em função de seus interesses como governante: "Este é um brinde comum a todos nós, holandeses, portugueses e brasileiros!” (BUARQUE; GUERRA, 1974, p. 65). Promete como parte das festividades a inauguração da Ponte Maurícia, causando o riso dos moradores. O boato que corria é que seria "mais fácil um boi voar” do que a ponte ser finalizada.

Nassau então inaugura a ponte e faz espetacularmente um boi voar - episódio curioso que de fato ocorreu, e foi incorporado pelos dramaturgos. Chico Buarque explicou em entrevista:

\begin{abstract}
A história do boi também é verídica. É o seguinte: havia um ditado naquela época que "é mais fácil um boi voar do que...”, sei lá, “o Flamengo ganhar”, por exemplo. Maurício de Nassau achou interessante este ditado e resolveu fazer um boi voar, para provar que, para ele, nada era impossível. Ele pegou um boi (tem a história contada do boi, com o nome do dono do boi e tudo), mandou matar o boi, encheu de palha, amarrou num... e o boi voou sobre a cidade. Na inauguração da ponte. (...) Aliás, são duas festas que a gente fundiu em uma (BUARQUE; GUERRA, 1973a, p. 27-8).
\end{abstract}

Dois fatos históricos protagonizados por Nassau são condensados em uma mesma cena: a inauguração da ponte e o voo do boi. A marchinha Boi voador não pode acompanha as comemorações. Ao mesmo tempo, o Consultor informa Nassau de que a trégua assinada entre Portugal e Holanda só vale para as metrópoles. Na colônia o estado de guerra permaneceria por mais alguns meses. Os dois combinam então um ataque ao Maranhão para conseguir mais conquistas aos portugueses.

lírico ter traído um amigo. A primeira e a segunda estrofes podem ser mais facilmente tomadas como canção de desamor, entoada por um eu lírico que viveu uma separação e que encontra um novo parceiro, menos amado do que o anterior. Outra diferença no trecho aqui citado é a mudança de "Guardada aqui" para "Guardada em mim” realizada na maioria das gravações. Essas duas alterações na letra constam já na gravação do próprio Chico Buarque, no disco Chico Canta (1973). 
Peixoto resumiu esse trecho nos seguintes subitens: “A política (tática) de conciliação de Nassau / A promessa do boi voador / O cálice sagrado e o cálice profano / A missa transformada em orgia” (BUARQUE; GUERRA, 1973b). Sua síntese dá conta do movimento espiritual (da missa à orgia, do sagrado ao profano) e do movimento político da cena (de uma comemoração católica e portuguesa a uma festividade de todos os moradores em torno das obras de Nassau).

Masetti formulou mais uma crítica à dramaturgia: "Estava clara a ideia de transformar uma coisa sacra em profana. Mas não estava claro o porquê. Eu atribuo isso a um problema de texto também. O problema da Restauração que não ficou clarificado o suficiente” (1973). A falta de clareza sobre a motivação das cenas de festa e orgia deu margem, na encenação, para um trabalho corporal cheio de alegria, mas nem sempre conectado com os debates políticos pretendidos.

A fala de Masetti está ligada à sua crítica anterior, de que haveria um salto temporal grande entre a chegada de Nassau ao Brasil (em 1637) e a coroação de Dom João Quarto em Portugal (que ocorreu em 1640). Alguns fatos históricos eram retratados na peça; era tarefa da equipe de direção compreender o seu papel para os debates veiculados pela dramaturgia como um todo. Novamente a ausência do herói ou traidor - Calabar produzia consequências desafiadoras. Ele não poderia subir no palco para dizer o que pensava sobre a Restauração Portuguesa ou o governo de Nassau em Pernambuco.

A cena seguinte volta a alimentar a imaginação do espectador a esse respeito. Sabemos de Calabar que ele morreu por um Brasil menos curvado aos interesses estrangeiros. O Consultor (representante da Holanda e da Companhia das Índias Ocidentais) cobra Nassau; informa-lhe que a metrópole desaprova seus investimentos na cidade do Recife. Peixoto assim resumiu o diálogo: “A paixão de Nassau, sua doutrina (a ideia de colonização baseada na liberdade de culto, comércio, tradições - sem monopólios) (Tudo isso e defesa da indústria do açúcar mesmo) - sua postura contra a monocultura” (BUARQUE; GUERRA, 1973b) ${ }^{160}$. A anotação dá conta do lugar contraditório de Nassau. Ele é um agente da colonização holandesa, mas busca um modelo menos opressivo (em termos religiosos e de costumes) e economicamente mais vantajoso para os brasileiros (pois incentiva que a produção do açúcar conviva com a de outros produtos).

\footnotetext{
${ }^{160}$ Na primeira versão textual essa cena se dava mais cedo, próxima ao início do segundo ato. A mudança de lugar na estrutura da peça não alterou significativamente o diálogo entre Consultor e Nassau.
} 
A próxima transição é realizada, segundo a rubrica, ao som do fundo orquestral de Tira as mãos de mim, canção de Bárbara a Souto; a música volta a operar com a lógica do leitmotiv. Na segunda cena íntima da dupla, Bárbara propõe proteção e amor a Souto, mas ele recusa a ideia de paz. Bárbara diz que a guerra de Souto não tem mais sentido, ao contrário da guerra de Calabar, que tinha sentido. Souto grita enlouquecido o nome de Calabar, chamando a atenção dos soldados holandeses, que o matam com tiros. Disse Peixoto: “O importante era a definição do Souto, isso acho que estava claro. O Souto se definindo, assumindo Calabar, e levando-o à loucura. (...) Essa continuidade, no nível do desenvolvimento psicológico mesmo do personagem, e esse clima neurótico da cena” (1973).

O foco do diretor no desenvolvimento psicológico do personagem é necessário para essa cena. Em outras cenas, e no trabalho com outros personagens, sua abordagem era diferente. Peixoto escreveu à época que o primeiro problema para o espetáculo era “encontrar a dosagem entre um realismo crítico distanciado e um psicologismo existencial, exposto com vigor e penetração. Mas todos os recursos são válidos para desvendar esta rede de traições” (PEIXOTO, 1989c, p. 155). Esse problema ligado à atuação tinha raízes na hibridez da própria dramaturgia. Ruy Guerra comentou:

Os personagens, na maioria, aparecem como dados prontos, entram de um jeito e saem iguais. A Bárbara e o Souto não. O Souto muda um pouco, vai mais longe dentro dele. Mas vai justamente mais longe dentro da traição. Vai assumindo a traição nos níveis mais inferiores da traição. (...) [Calabar] lutava por uma ideologia, e ele não. Souto é um traidor uterino, congênito, trai por prazer de trair (BUARQUE; GUERRA, 1973a, p. 20-21).

A fala explicita a diferença entre a trajetória de Souto e Bárbara, que se modificam, e os demais personagens, que tendem à tipificação. Figuras como o Frei, o Consultor, Dias e Camarão mantinham as mesmas características em todas as suas cenas. Mas a proposta de discutir a traição também em seu sentido amoroso dependia de personagens complexas, cuja vida interna apresentasse contradições. Uma dramaturgia de caráter predominantemente épico pode lançar mão de cenas dramáticas para aprofundar temas e situações.

Segue-se a última cena de caráter íntimo da peça, ainda que entrecortada por intervenções do coro. Anna vem consolar Bárbara pela morte de Souto. Fala mal do amor dos homens, e canta versos de Anna e Bárbara, o leitmotiv das duas. Em seguida, 
a canção transforma-se em Vence na vida quem diz sim, que de acordo com a rubrica é cantada por Anna acompanhada pelo coro. Peixoto definiu a canção como um número de “cinismo e ironia” (1973). A letra afirma que para vencer é preciso dizer “sim” após sofrer todo o tipo de ações, em sua maioria violentas (socos, dores, xingamentos).

Finda a canção a rubrica indica: “Anna paramenta Bárbara auxiliada por algumas escravas ${ }^{161}$ negras” (BUARQUE; GUERRA; 1974, p. 81). Esse grupo penteia, maquia e veste a viúva. A presença das mulheres escravizadas não é discutida com profundidade pela dramaturgia, mas produz contradições. Calabar é descrito por Mathias como "mulato"162, provavelmente filho de negros africanos escravizados. É estranho que uma prostituta convoque o serviço dessas mulheres para arrumar sua amada Bárbara, por sua vez descrita pelo Frei como mameluca (ou seja, descendente de índios e brancos). O quadro talvez produzisse uma imagem alegórica do Brasil, nação formada a partir de processos escravistas.

A escolha da cor do tecido é significativa: entre o amarelo (associado à bandeira brasileira) e o vermelho (cor associada à luta das esquerdas), Anna escolhe o tecido vermelho, “mais alegre” (BUARQUE; GUERRA, 1974, p. 82). O termo "paramenta” utilizado na rubrica talvez se referisse à transformação de Bárbara em uma representante da luta política. Os dramaturgos provavelmente se inspiraram em Brecht e na famosa cena da paramentação da peça A Vida de Galileu. Nela, conforme um Cardeal da Igreja é paramentado Papa, sua tolerância para com os estudos de Galileu Galilei se reduz drasticamente. Se no início da cena aquele homem defende a Matemática e diz que Galileu é o "maior físico deste tempo", ao final da cena ele aceita ameaçar o cientista com instrumentos de tortura (BRECHT, 1991, p. 146 - 149). O ato de vestir o personagem torna-se o ato de transformar o seu papel social.

Bárbara fica desatenta durante a sua paramentação, o que faz Anna se desesperar e dispensar as escravas. Bárbara então canta Fortaleza, canção que expressa sua tristeza,

\footnotetext{
${ }^{161}$ Há hoje em dia uma discussão em torno das palavras "escravo" e "escrava”. O movimento negro sugere sua substituição pelos termos "escravizado" e "escravizada", por evidenciarem que a condição de escravidão não é natural. Como Calabar foi escrito antes de esse debate ganhar espaço, seus autores ainda utilizaram o termo "escravas", como citado acima.

162 "Mulato" é mais um termo associado ao racismo, que é hoje evitado. No contexto da peça, ele é utilizado por Mathias de Albuquerque para descrever Calabar. É possível que o seu uso revele preconceito por parte do governante, descendente de portugueses e, provavelmente, branco. O Frei descreve Calabar como "mestiço", outra palavra possivelmente reveladora de preconceitos. O termo "mestiço" sugere uma mistura de etnias, mas também é utilizado para designar animais.

Chico afirmou em entrevista que havia dúvidas sobre a identidade étnica do Calabar histórico, descrito de diferentes maneiras em diferentes documentos: "não se sabe se ele era mameluco ou mulato. Às vezes era descrito como mulato, outras como mameluco" (BUARQUE; GUERRA, 1973, p. 23).
} 
sua surpresa, e descreve: "Minha fortaleza é de um silêncio infame / Bastando a si mesma, retendo o derrame / A minha represa” (BUARQUE; GUERRA, 1974, p. 84). Há uma provável relação entre essa canção e o marco, tipo de estrutura poética comum no Nordeste que se desenvolve em torno da exaltação sobre a própria fortaleza ${ }^{163}$. Mas aqui a personagem cantava o contrário da exaltação: não havia o que celebrar.

A partir desse canto Bárbara elabora o luto por seus dois amantes, relacionandoo a uma análise sobre a situação política. Peixoto anotou: "Ela agora distingue as traições de Calabar (orgulha-se) e de Souto (repugna-se)” (BUARQUE; GUERRA, 1973c). Mas a personagem vai mais adiante em sua avaliação: “Tudo isso que fez Calabar trair... Sebastião enlouquecer... Não valia a pena morrer por isto. Holandeses, portugueses, não valia a pena ter morrido por nada disso” (BUARQUE; GUERRA, 1974, p. 85). Fernando Peixoto anotou em seu texto: “TRAIÇÃO - não valia a pena morrer por nada (as opções históricas do momento)” (BUARQUE; GUERRA, 1973c). No Brasil de 1973, o texto talvez ecoasse a pergunta: de que valeu a morte dos guerrilheiros?

Era uma pergunta dolorida, um tema difícil de se lidar. Diferentes setores da esquerda faziam diferentes avaliações de conjuntura à época, o que os levava a estratégias distintas. Mas a morte é muito definitiva. A fala de que não valia a pena morrer por holandeses ou portugueses não teria a força de trazer Souto e Calabar de volta à vida.

Fernando Peixoto era membro do Partido Comunista, que à época se posicionou contra a luta armada brasileira, por avaliar que a conjuntura não era favorável. As “opções históricas do momento” seriam outras, os horizontes utópicos estavam rebaixados. Masetti falou sobre os sentimentos contraditórios de Peixoto e de outros membros do PCB a respeito da luta armada:

O Fernando falava muito contra. Mas ao mesmo tempo montou a peça do Boal, Murro em ponta de faca. Num momento que o Boal já estava exilado... Mas isso tudo eu ponho por conta do "Vastas emoções e

\footnotetext{
163 Segundo Santos (2011): “O marco é um tipo de estrutura poética usada por cantadores nordestinos e poetas de bancada. Utilizado por improvisadores como demarcação de espaço geográfico para a sua cantoria, no começo do século XX o marco começa a surgir nos folhetos como rubrica para marcação de autoria. O poeta escreve um marco para exaltar seus dotes artísticos e deixar uma marca de sua poesia. $\mathrm{O}$ marco é uma fortaleza indestrutível da qual o poeta, canta, afama, celebra sua própria construção e desafia qualquer outro sujeito a vir atentar contra seu castelo”. Uma análise mais aprofundada da canção Fortaleza sob essa perspectiva ficará para uma próxima ocasião.
} 
pensamentos imperfeitos” ${ }^{164}$. O Guarnieri também, era do Partidão. Mas ficou atônito com a morte do Vladimir Herzog. Entendeu? Que era um cara do Partido mas que foi uma morte como se tivesse sido o pior guerrilheiro do mundo. Que não era, mas enfim. Então, quer dizer, a direita vinha também com atitudes assim, que faziam as pessoas perderem o rebolado ${ }^{165}$.

A dramaturgia de Calabar era fruto desse tempo histórico descrito por Masetti, tempo de exílios e assassinatos, de “vastas emoções e pensamentos imperfeitos”. Artistas alinhados com diferentes organizações políticas faziam diferentes leituras de conjuntura, mas uma análise fria era impossível. Retomando a cena de Anna e Bárbara, os corpos mortos ainda jaziam frescos no chão. Na encenação censurada, bonecos ${ }^{166}$ mortuários presentificavam os guerreiros deixados sem sepultura.

A personagem Bárbara recoloca o tema da escrita da História: "Tudo que Calabar disse e fez, foi de peito aberto, às claras, sem mentiras. Se é necessário chamar Calabar de traidor, que chamem Sebastião do Souto de herói” (BUARQUE; GUERRA, 1974, p. 85). Calabar ficou marcado como traidor na História oficial, o que faria de Souto um herói. Na analogia com a luta armada contra a ditadura, Lamarca provavelmente também seria narrado como traidor do exército. Seriam os militares no poder alçados a heróis? A discussão sobre a figura do herói na História e no teatro brasileiros continuava em pauta, recheada de contradições. A cena termina com Bárbara enfeitada, e Anna se declarando: "Você está linda... Louca e linda. Eu te amo, Bárbara” (p. 85).

Seguem-se duas cenas simultâneas: um diálogo de Bárbara e Frei e outro diálogo entre o Consultor e Nassau. Bárbara cobra a falta de coerência do Frei, que se favorecia do domínio holandês, mas seguia chamando Calabar (que lutou ao lado dos mesmos holandeses) de traidor. Sua pergunta reitera o ambiente mortuário da peça e do tempo histórico: “E o morto, Padre? O que é que a gente faz do morto?” (BUARQUE; GUERRA, 1974, p. 87). O Frei responde que Calabar é um assunto encerrado: "E quem disser o contrário atenta contra a segurança do Estado e contra as suas razões. Por isso o

164 "Vastas emoções e pensamentos imperfeitos" é o nome de um livro de Rubem Fonseca. Mário Masetti citou a frase diversas vezes ao longo da entrevista, como uma espécie de expressão que definiria sua vivência e a de outros companheiros durante a década de 1970. Ela daria conta da mistura entre vivências políticas intensas (organização política, debates entre diferentes movimentos, perseguição, exílio e assassinato de companheiros) e de experiências pessoais também intensas (a criação artística, a convivência com outros artistas jovens e libertários, a experimentação do desbunde, a estadia no Rio de Janeiro).

165 MASETTI, Mário. Entrevista sobre Calabar. Entrevistadora: Nina Hotimsky. São Paulo, nov. 2016.

${ }^{166}$ Esses bonecos serão melhor abordados no capítulo 3. 
Estado deve usar do seu poder para o calar. Porque o que importa não é a verdade intrínseca das coisas, mas a maneira como elas vão ser contadas ao povo” (p. 88). Desde o momento da execução ficava clara a intenção de matar, ao mesmo tempo, Calabar e a memória de sua luta. O Frei aqui explicita o poder do Estado de calar quem insistisse em lembrar o traidor. O poder do Estado de calar possuía em 1973 sentidos de atualidade imediatos. Naquele momento a censura era institucionalizada (e silenciou inclusive o espetáculo Calabar).

Ao mesmo tempo em que o Frei e Bárbara dialogam, o Consultor comunica a Nassau uma decisão oficial da Companhia das Índias e dos Estados Gerais ${ }^{167}$ : o governador é obrigado a renunciar. Nassau não se mostra surpreso com o anúncio. Ele faz um balanço sobre as contradições de sua gestão, e se classifica também como traidor. Afinal, utilizou recursos holandeses em seu projeto megalomaníaco de modernizar o Recife. Retoma então a canção de Mathias em chave séria: "esta terra ainda vai cumprir seu ideal / Ainda vai tornar-se um imenso canavial”. (BUARQUE; GUERRA, 1974, p. 90). A troca de "Portugal” e "Império Colonial” (termos presentes na primeira exposição de Fado Tropical) por “canavial” desloca o problema político imediato para um problema econômico de longo prazo. Fosse para enriquecer Portugal, Holanda, Espanha ou os Estados Unidos, essa terra seguiria sendo usada para a monocultura de exportação.

Bárbara avança para afirmar o contrário: que um dia o Brasil será independente. Um dia, todos os países poderão ser independentes. "Mas isso requer muito traidor. Muito Calabar. E não basta enforcar, retalhar, picar... Calabar não morre, Calabar é cobra de vidro. E o povo jura que cobra de vidro é uma espécie de lagarto que quando se corta em dois, três, mil pedaços, facilmente se refaz” (BUARQUE; GUERRA, 1974, p. 90). Há aí uma citação e uma homenagem: Sérgio Buarque de Hollanda, pai de Chico Buarque que ajudou os dramaturgos na pesquisa, publicou um livro de críticas com o nome Cobra de Vidro, título inspirado por esse réptil tão falado pelo povo ${ }^{168}$.

Bárbara canta então a canção Cobra de Vidro:

\footnotetext{
${ }^{167}$ É interessante observar a variação entre representação de interesses públicos e privados nas falas do Consultor. Diversas vezes ao longo da peça ele se refere ao que é bom "para a Holanda". Aqui ele se diz primeiramente porta-voz da Companhia das Índias (termo econômico que designa uma empresa de comércio holandês), e em segundo lugar como porta-voz dos Estados Gerais (referindo-se aos Estados Gerais dos Países Baixos, termo político e geográfico que inclui a Holanda). O personagem do Consultor explicita a relação íntima entre as ações de um Estado e os interesses de sua classe dominante.

168 O livro de Sérgio Buarque de Hollanda abre com a seguinte citação: “... o povo jura que tais "cobras”, depois de partidas em vários pedaços, facilmente se refazem... Rodolfo Von Ihering - Dicionário dos Animais do Brasil. São Paulo, 1940” (HOLLANDA, 1944, p. 5).
} 
Aos quatro cantos o seu corpo / Partido, banido / Aos quatro ventos os seus quartos/ Seus cacos de vidro / O seu veneno incomodando / A tua honra, o teu verão / (com coro) Presta atenção! / Presta atenção! Aos quatro cantos suas tripas / De graça, de sobra / Aos quatro ventos, os seus quartos / Seus cacos de cobra / O seu veneno arruinando / A tua filha e plantação / (com coro) Presta atenção! / Presta atenção!

Aos quatro cantos seus ganidos / Seu grito medonho / Aos quatro ventos os seus quartos / Seus cacos de sonho / O seu veneno temperando / A tua veia e o teu feijão / (coro) Presta atenção / Presta atenção / Presta atenção / Presta atenção / Presta atenção (BUARQUE; GUERRA, 1974, p. 90-91).

Há na letra uma retomada de imagens presentes na sentença de Calabar, por sua vez pesquisada em documentos históricos. É no momento da execução que se obriga a jogar o corpo esquartejado "aos quatro cantos”, a salgar o chão e a declarar infames os descendentes do morto (arruinando a plantação e a filha). A sentença afirma que com isso o condenado servirá de exemplo, e não perdurará na memória (BUARQUE; GUERRA, 1974, p. 34). A canção inverte a intenção dos poderosos: propõe que a luta de Calabar não será esquecida, e que ele servirá de exemplo não para produzir medo, mas para incentivar a coragem de novos guerreiros e guerreiras.

Cobra de Vidro é uma síntese poderosa da peça Calabar em relação com seu tempo histórico. A letra descreve a violência da repressão e a desagregação do sujeito que lutou. Cada uma das três estrofes se dedica a uma parte dessa descrição. Está despedaçado o corpo, feito cacos de vidro. Estão despedaçadas as tripas, que a letra aproxima da imagem da cobra. E está despedaçado o ganido ou o grito: a última estrofe associa a desagregação da voz com a desagregação do sonho.

Apesar dessa imagem de terra arrasada, o coro (também chamado de "Povo" pela equipe de direção) se alia com Bárbara para cantar o refrão. E o refrão é imperativo: “Presta atenção!”. Ao final da peça, o subtexto é o seguinte: Calabar foi esquartejado, mas seu grito, seu sonho e seu veneno seguiriam se refazendo.

A música é tensa todo o tempo, traduzindo sonoramente a ordem "Presta atenção!”. Vale lembrar que uma versão instrumental já havia sido tocada no primeiro ato, logo após a sentença de Calabar ser proferida. A ideia de desagregação presente na metáfora do animal (e no esquartejamento do herói) se faz sentir durante a escuta. Na gravação presente em Chico Canta (1973), um piano com dados jazzísticos não dá trégua, com fraseados rápidos e pouco tempo de repouso. Um chocalho lembra o som 
que certas cobras peçonhentas fazem com suas caudas, contribuindo para a materialização da metáfora fundamental da canção.

Os metais da introdução (timbres que no espetáculo provavelmente entrariam através do playback) parecem anunciar problemas. Um deles faz uma frase rítmica na nota lá, enquanto o outro, mais grave, toca quatro vezes a sequência descendente lá - ré. A repetição dessa sequência de duas notas por um timbre grave durante a introdução sugere que a música repousaria em um acorde de ré, mas esse repouso é raríssimo durante a harmonia. O acorde de ré menor só aparece no primeiro compasso de cada verso $^{169}$. Assim como a letra, a música não caminha para uma fácil resolução.

Durante a execução da letra os metais atacam notas em resposta a certas frases cantadas, e soam como sustos, ou como gritos. Os instrumentos de sopro, afinal, têm a predisposição de fazer lembrar a voz humana. A sua presença se intensifica a cada estrofe. No refrão, que fica no acorde de lá maior, os metais também acompanham o caminho em semitons que varia entre a sétima maior de lá e a quinta aumentada de lá. Essa presença de semitons (e o próprio timbre dos metais) provavelmente colaborava para instauração de uma tensão cênica, para além das tensões na harmonia musical. Se os semitons de Tatuagem expressavam o encontro erótico de dois amantes no momento da morte do homem amado, os semitons de Cobra de Vidro colaboravam para instaurar uma suspensão, um suspense, uma falta de resolução. Calabar estava morto, mas eram muitas e diversas as vozes que seguiam gritando. De semitom em semitom os gritos se fariam ouvir. Os cacos de sonho poderiam voltar a se $\operatorname{colar}^{170}$.

Peixoto descreveu Cobra de Vidro como “O grande final da peça” (1973). Para um encenador implicado em construir uma arte nacional popular com perspectivas revolucionárias, essa canção era fundamental. Mesmo sem prometer a vitória, mesmo musicalmente apostando mais em tensões do que em resoluções, mesmo se constituindo como uma ameaça de vingança sem garantia de resultados: Cobra de vidro era o ápice de qualquer esperança de transformação social veiculada por Calabar.

O que vem depois não possui a mesma grandiosidade, mas dá conta das conclusões. Acontece a festa de adeus para Nassau, com faixas de saudações, índios

\footnotetext{
169 Consultamos a partitura que consta no Songbook de Chico Buarque. CHEDIAK, Almir. Chico Buarque - Songbook volume 4. Rio de Janeiro: Lumiar, 2010.

${ }^{170}$ Muitas outras canções politizadas de Chico Buarque instauram mais expectativas do que certezas. Como observou Meneses, há um “caráter reivindicativo e vingativo que as canções assumirão, num misto de recusa e espera. Recusa do atual, espera de uma realidade renovada (...), mas espera que é exigência: é assim que se apresentarão as canções de protesto de Chico Buarque” (1982, p. 70-71).
} 
cientistas e negros pintores - uma expressão bem-humorada de suas intenções modernizadoras. Nassau faz um discurso do alto de sua ponte, no qual, segundo Peixoto, fica clara “a contradição do Nassau entre homem de letras e militar” (1973). Embora sua despedida cause alguma comoção, Nassau nunca representou unicamente os interesses dos moradores do Recife. E suas ideias humanistas conviveram sempre com a empreitada bélica de ampliar os territórios dominados pelos holandeses. Após as declarações oficiais do antigo governante, Bárbara dá o seu “recado final” (1973) diretamente para os espectadores. Ela os convoca a serem sãos, aplaudirem, viverem, beberem e traírem.

A canção Elogio da Traição fecha o espetáculo. Ela é cantada por todo o elenco, segundo a rubrica, “até baixar o pano” (BUARQUE; GUERRA, 1974, p. 93) Sua letra diz que o que é bom para a Holanda (e para Luanda, Espanha, Alemanha e outras nações e indivíduos diversos) é bom pro Brasil. Há uma provável referência ao pronunciamento de Juraci Magalhães, embaixador do Brasil nos EUA que participou do golpe de 1964 e afirmava: “O que é bom pros Estados Unidos é bom pro Brasil” (MARTINS, 2007, p. 111). Para Peixoto, essa canção seria um momento de desbunde, ironia e cinismo (1973).

Como visto, a relação entre formas e temas presentes na dramaturgia é das mais complexas. Há na peça um ambiente mortuário: um herói (ou traidor) morto, seu sangue em uma bacia, a tortura de um preso, o assassinato de Souto, guerras coloniais. O povo do Recife está presente em cena, mas pouco interfere no enredo. Ele observa, canta, mas pouco age.

Conflitos religiosos encobrem um conflito material. Mais do que uma obra sobre protestantes e católicos, trata-se de uma peça que retrata a disputa colonial por territórios brasileiros. O objetivo é lucrar com o açúcar produzido no país. Em meio aos interesses econômicos estrangeiros, a quem os brasileiros devem a sua lealdade?

O debate em torno da ideia de traição é explorado nos âmbitos público e privado. Junto a ele, há um questionamento sobre o que é ser um herói. Ambos os termos traidor e herói - se ligam a uma disputa em torno da História. Quem narra a História brasileira? Quais os interesses por trás dos discursos oficiais? Acompanhamos na peça o esforço dos poderosos para matar a memória de Calabar. São os vencedores que formulam as narrativas hegemônicas a respeito do passado. Mas Bárbara e outros bárbaros insistem em cantar o veneno vivo de uma luta que pode ser recomposta. 
Está em disputa a própria ideia de nação e povo brasileiros. Como formulou Guerra, se debate em Calabar “o conceito de Pátria. Porque é coisa fundamental da época. Quer dizer: naquela época, tínhamos os brasileiros, os portugueses, os espanhóis, os holandeses, aquela confusão toda. Havia uma série de divisões internas” (BUARQUE; GUERRA, 1973a, p. 24-5). No Brasil da década de 1970, outros grupos estavam em confronto pela ideia de nacionalidade. Artistas e intelectuais de esquerda se reuniam em torno da ideia de uma cultura nacional popular. O PCB e outros movimentos organizados militavam contra o imperialismo, almejando uma economia menos curvada a interesses estrangeiros. Já os militares no poder veiculavam um tipo de patriotismo ligado à obediência: Brasil, ame-o ou deixe-o. Desenhavam um povo brasileiro ordeiro, cristão, defensor da propriedade privada, um povo ligado à família e avesso ao fantasma do comunismo. Esse projeto encontrava apoio em setores da sociedade civil. As divisões internas apresentadas em Calabar aludiam a esses dados de atualidade.

Os temas veiculados pela peça são apresentados em uma estrutura de quadros. A dramaturgia não aponta para uma harmonia formal. Há cenas cômicas (figuras farsescas, situações escatológicas, retrato alegórico de poderosos) convivendo com momentos líricos e envoltos em tragicidade. Percebe-se uma inspiração no teatro épicodialético de Brecht, que buscava uma relativa autonomia entre as partes de uma obra: “cada cena em função de si mesma” (BRECHT, 2005, p. 31).

Essa variação formal pode também ser lida como uma característica dos dramaturgos, um cineasta e o outro compositor. A linguagem do cinema trabalha muito a partir da montagem, e Ruy Guerra tem experiência com essa função. O montador costura imagens e sons diversos para compor um filme; um procedimento semelhante é adotado em Calabar. Segundo Peixoto, há no texto "uma unidade que se manifesta justamente na descontinuidade quase cinematográfica do relato. Cada cena se exprime livremente, independente das demais, em termos de estrutura. Mas o todo conserva uma linha dramática consequente, lógica, objetiva” (1989c, p. 155). Já as canções musicadas por Chico Buarque ajudam a instaurar o lirismo e o erotismo que, de outra forma, poderiam não caber após momentos de humor escatológico.

Essa maneira de trabalhar com as canções aproxima formalmente Calabar dos musicais do Arena. O Sistema Coringa propunha o ecletismo de gênero e estilo. Mas enquanto o Arena contava a trajetória de heróis, Calabar gira em torno de um herói 
incerto e ausente, um homem acusado de traição. Outros supostos heróis povoam a peça, aqueles que a História oficial elegeu: Dias, Camarão e Souto. Suas ações são omissas, egoístas e covardes, nunca heroicas.

O personagem que dá nome à peça é executado ainda no primeiro ato, e a peça insiste em seguir sem ele. Masetti critica o excesso de cenas íntimas no segundo ato; talvez fosse mesmo um desafio dar continuidade à peça e sustentar o interesse dos espectadores após a execução de Calabar. Todo o segundo ato, que retrata a tentativa de “modernização conservadora” de Nassau, se desenrola sem que ocorram melhorias estruturais para a vida dos brasileiros. Se no primeiro ato ainda acompanhamos as tentativas de Bárbara por salvar seu amado, a metade final da peça não veicula grandes esperanças. O cinismo ganha espaço; a derrota está dada.

Nisso a peça (desequilibrada, assimétrica, torta) reflete bem os anos 1970 e os impasses dos próprios artistas. Ela mostra uma ferida aberta, uma sensação de paralisia histórica. Como seguir narrando e cantando enquanto os corpos mortos jazem frescos, e a esperança despedaçada? Peixoto, em certa medida, buscou com a encenação unir os cacos e apontar um vislumbre de luta popular. Sua tentativa foi censurada, mas é reveladora de princípios que orientaram o seu fazer teatral e o de outros artistas do mesmo período. 


\section{Capítulo 3 - A encenação censurada}

A dificuldade de estudar uma encenação teatral ocorrida no passado é evidente. O teatro é uma arte ligada à presença; nenhum documento ou relato substitui a experiência de se assistir a um espetáculo ao vivo. Embora contando com diversas fontes documentais, jamais passaremos pela experiência de ser espectador do Calabar de 1973. Muito menos, um espectador com a sensibilidade de uma pessoa daquela época.

Além disso, o fato de a peça ter sido impedida de estrear tornou-a, para sempre, incompleta. Na fita em que descreve a encenação, Peixoto abre com a seguinte frase: “Primeira coisa que existe no espetáculo, acho, é que ele não ficou pronto(...). Então o que a gente está conseguindo julgar, talvez fazendo uma autocrítica nesse nível, é de um espetáculo não terminado” (1973). O diretor faz questão de registrar o problema, mas é fato que chegou a ocorrer ao menos um ensaio geral com a plateia lotada ${ }^{171}$. E os espectadores presenciaram um espetáculo que já se realizava do começo ao fim, sem interrupções. Herbert Richers Júnior, um dos espectadores, descreveu uma obra bela e espetacular, que a seus olhos parecia completa.

A sensação de inacabamento de Peixoto está em parte ligada à ausência de uma temporada. Para Dori Caymmi, “eles estavam ensaiando, eu acho que foi pouco tempo. Eu acho que essa peça engrenaria no ar. Ela estava crua, na minha opinião, musicalmente" 172 . O responsável pela parte musical comentou sobre a sua área de trabalho especializado. Mas as metáforas que ele utiliza (“engrenar no ar”, como se a peça fosse um avião que ajusta a rota, e "crueza”, como se fosse necessário que a obra passasse mais tempo no forno) são frequentes entre os artistas de teatro. É comum que montagens teatrais amadureçam conforme são apresentadas. $\mathrm{O}$ encontro com os espectadores produz retornos imprevistos, o que permite que a equipe criativa faça ajustes na obra.

\footnotetext{
171 O próprio Peixoto, no texto Histórico de um aborto, publicado em 1974, afirmou que o espetáculo estava pronto. "Dia 30 de outubro (com o espetáculo pronto e a estreia marcada para 8 de novembro) a empresa Fernando Torres Diversões faz requerimento à censura Federal para que fosse marcado o ensaio geral da referida peça, a fim de obter o alvará do espetáculo” (1989c, p. 159). Nesse caso, a afirmação dava mais peso à denúncia de arbitrariedade por parte dos organismos de Censura. Ao analisar a montagem do ponto de vista artístico, no entanto, o diretor ainda o via como inacabado.

${ }^{172}$ CAYMMI, Dori. Entrevista sobre Calabar. Entrevistadora: Nina Hotimsky. Rio de Janeiro, jan. 2018.
} 
Peixoto percebe como essa falta de encontro da obra com seus espectadores e com a crítica especializada aumentou o peso de sua autocrítica:

Talvez isso: espetáculos meus anteriores em contato com o público, funcionando em relação com o público, sendo compreendidos, sendo aplaudidos, e sendo inclusive criticados (sem grande incidência interpretativa mas pelo menos sendo aceitos pela crítica), tenham me levado a me deixar satisfeito com o trabalho realizado. E o fato de Calabar não ter sido encenado levou eu mesmo a fazer a reflexão crítica como público e como crítico, vamos dizer assim, diante do próprio trabalho, num nível bem mais exigente (1973c).

Um diálogo entre Calabar, seu público, e a crítica especializada poderia ter produzido documentos fundamentais. Na ausência deles, é a voz dos artistas envolvidos que testemunha a encenação quase finalizada. A partir de seus depoimentos é possível tentar realizar uma reconstituição crítica de determinados aspectos da encenação. A análise será balizada pelas reflexões de Fernando Peixoto.

$\underline{\text { Povo em luta: a “opção brasileira” em um coro de herói ausente }}$

Na dramaturgia de Calabar o possível herói positivo (cuja voz nunca escutamos, e só enxergamos na contraluz) era executado no meio do primeiro ato. Os vivos Camarão, Dias e Souto são chamados de heróis, mas em nada contribuem para melhorar a situação dos habitantes do Recife. A arraia-miúda também não está organizada e pronta para a luta. Bárbara diz que é preciso “muito Calabar” para esse país ser independente: o herói morto é talvez substituível, como o herói humilde proposto por Rosenfeld (1996), mas ele ainda não foi substituído.

Talvez essa perspectiva fosse exageradamente pessimista para Fernando Peixoto. Ao deparar-se com uma produção de tamanho porte, com tantos recursos e com a possibilidade de ser assistida por um número significativo de espectadores, ele se perguntou: como incluir um vislumbre de transformação social? O pressuposto de lealdade à dramaturgia convivia com a possibilidade de criar um enunciado da encenação, afinado com determinadas posturas ideológicas. Como o diretor explicou, em texto destinado ao programa do espetáculo:

Cada imagem cênica, cada gesto ou movimento, procura traduzir visualmente um conceito, resultado de uma reflexão dialética sobre o significado da cena. Neste sentido se tornam ridículas as diferenças 
entre personagens centrais e personagens secundários. Uns não existem sem os outros e todos os atores, estejam em primeiro plano, com a responsabilidade de um monólogo em versos brancos de uma página, ou no fundo do palco, segurando uma lança, imóveis, dividem entre si, cada um com sua tarefa, a responsabilidade pelo significado total do que é visto, sentido, compreendido. A escritura cênica, neste sentido, interpreta o texto, definindo uma moral, uma ética, uma opção ideológica (PEIXOTO, 1989c, p. 157).

Peixoto concentrou muitos de seus esforços na constituição de um povo em cena. Para tanto, os personagens ditos secundários assumiram uma importância fundamental. Logo no início do diálogo com Masetti o encenador apresenta essa ideia. Comenta que faltou tempo para finalizar a encenação, e que por isso "não deu para realizar totalmente a ideia de trabalhar o povo, trabalhar o coro que a gente chamava, coro no sentido de pessoas em permanente atividade, em trabalho. Seria vamos dizer assim a moldura - moldura não - o pano de fundo do espetáculo inteiro” (1973).

O fato de ele corrigir o termo "moldura” para "pano de fundo” é significativo. Vimos que o encenador tinha como uma de suas inspirações o diretor Manfred Wekhwerth, que trabalhou com Bertolt Brecht no Berliner Ensemble. Em seu livro sobre o trabalho de encenação, Wekhwerth valoriza muito os ensaios de marcação ${ }^{173}$. Ele compara os arranjos cênicos a quadros de artistas visuais importantes, como Pieter Bruegel, pela forma como podem revelar as relações entre os homens e sua posição social (WEKHWERTH, 1986, p. 109). Há uma relação direta entre o recurso estético da marcação e a opção teórica e política pelo materialismo dialético: “É a partir do arranjo cênico que a irrupção do materialismo na selva do teatro pode ser realizada do modo mais simples possível” (WEKHWERTH, 1986, p. 112). É por isso que o coro de Calabar não poderia ser moldura, e sim fundo. Sua presença era fundamental para compor o quadro das relações sociais debatidas pelo espetáculo.

Ao final da fita Peixoto retoma o problema do coro:

O que mais senti mesmo foi... Aquela ideia original que se tinha, de enxertar as cenas com o trabalho. Fazer essa história acontecer toda com o povo trabalhando e vivendo. Isso estava esboçado, e havia muitas cenas que se realizavam, mas não se realizava no total (1973).

\footnotetext{
${ }^{173}$ Fernando Peixoto fazia desenhos da marcação em seus cadernos de direção. Ali registrava a disposição espacial dos atores para determinadas cenas. A imagem de uma dessas páginas de seu caderno está disponível como anexo da dissertação (Figura 7 - Anexo C).
} 
A partir desses trechos podemos compreender a importância do coro para a constituição da conjuntura social em que os protagonistas agiam. Mas os planos de Peixoto para o coro vão mais adiante: “a opção brasileira que não existe na peça poderia talvez ser encarnada na arraia-miúda” ${ }^{174}$ (1973).

A arraia-miúda daria corpo para uma ideia em disputa. O termo “opção brasileira” era usado de diversas maneiras no contexto da militância de esquerda. Peixoto o utilizou como sinônimo de "luta de libertação nacional”, em texto escrito para o programa do espetáculo ${ }^{175}$ (1989c, p. 152). A expressão “opção brasileira” condensava o seguinte debate: qual seria a natureza de uma possível Revolução brasileira? ${ }^{176}$ Quais grupos poderiam se constituir como sujeitos revolucionários? A polêmica partia do fato de que, apesar de a ideia de comunismo almejar um internacionalismo, a luta pela mudança estrutural da sociedade capitalista assumia formas diferentes em contextos políticos e sociais diversos. A recente Revolução Cubana aquecera as discussões, pois era possível estudar as particularidades de uma luta travada na América Latina.

A formulação de Peixoto parte do fato de que a dramaturgia é mais crítica do que propositiva. Não existia “opção brasileira” no texto; ele não retratava um Brasil revolucionário (qualquer que fosse a natureza dessa Revolução). Havia, no máximo, o desejo de a cobra-luta unir seus pedaços.

A canção Cobra de vidro é um ponto da dramaturgia que endossa a concepção de Peixoto: surge aí a chance de colocar em cena um povo politicamente organizado,

\footnotetext{
${ }^{174}$ Vimos como "arraia-miúda” e "povo" tornaram-se maneiras de se referir ao coro de 28 atores durante os ensaios.

175 Os dois termos são aproximados por Peixoto em um parágrafo em que ele analisa o contexto histórico em que Calabar se passa, o século XVII no Brasil. A frase completa é a seguinte: "Não existem ainda condições maduras, do ponto de vista social, econômico, nem político, para uma opção brasileira, para uma luta de libertação nacional” (PEIXOTO, 1989c, p. 152).

${ }^{176}$ O debate em torno da ideia de "opção brasileira" incluía questões como: a revolução brasileira partiria do proletariado? Do lumpen proletariado? Seria necessária uma aliança com a burguesia nacional para industrializar o país ou, pelo contrário, a burguesia no Brasil jamais seria revolucionária? Mário Pedrosa, artista e pensador ligado ao trotskismo, em livro de 1966 intitulado A opção brasileira "atacava a hipótese, formulada principalmente pelo PCB, de que seria possível uma revolução burguesa no Brasil" (MANOLO, 2009). Pedrosa escrevia pouco após o golpe civil-militar, em um momento em que era necessário produzir uma crítica às condutas adotadas até então pelas esquerdas.

É possível que Fernando Peixoto tenha lido o livro de Pedrosa. O encenador era membro do PCB, mas não necessariamente concordava com todas as ideias defendidas pelo Partido. Vimos, por exemplo, como o encenador se encantou pelo pensamento de Marcuse; ao encenar Poder Negro, discutiu a ideia de que a revolução "será feita pelos marginais" (PEIXOTO, 1989b, p. 156).

Há também um livro de 1996 chamado A opção brasileira, organizado por César Benjamin, que conta com análises de diversos intelectuais de esquerda. O termo, em uma nova conjuntura, seguiu sendo objeto de discussão. Como se pode notar, esses debates são bastante complexos, e não poderão ser aprofundados nos limites dessa dissertação.
} 
capaz da possibilidade de transformação, figurado no coro. A importância de Cobra de Vidro fica clara no texto que o encenador escreveu para o programa do espetáculo. O texto, intitulado “Uma reflexão sobre a traição” ${ }^{177}$, tinha como epígrafe a primeira estrofe da letra dessa canção (PEIXOTO, 1989c, p. 151).

O musical político dos anos 1970 não cantava a luta com o mesmo otimismo dos musicais e das canções de protesto apresentadas entre 1964 e 1968, pois muitas derrotas já se acumulavam ${ }^{178}$. Uma comparação entre a canção Cobra de Vidro e as canções de protesto presentes nos musicais Arena conta Zumbi e Arena conta Tiradentes dá a ver essa mudança histórica. Zumbi termina com o coro cantando que "lutar afinal / é um modo de crer / é um modo de ter / razão de ser” (BOAL; GUARNIERI, 1965, p. 92). Em Tiradentes o coro afirma que o povo "Quanto mais cai mais levanta / Mil vezes já foi ao chão / Mas de pé lá está o povo / Na hora da decisão” (BOAL; GUARNIERI, 1967, p. 163). Cobra de vidro não promete o povo de pé, a luta, nem mesmo a crença e o sentido de vida. A canção descreve com detalhes o esquartejamento do herói; do guerrilheiro morto restavam cacos de sonho e algum veneno. O que o coro faz é alertar para que se preste atenção: é possível que a luta se refaça.

Tomando Cobra de Vidro como um ponto culminante para a presença do povo na peça, Peixoto formulou três momentos essenciais para o coro:

O povo teria três momentos. Três arraias-miúdas. Nesse momento ele funcionaria isoladamente, trabalhando em pontos isolados do espaço cênico. E na segunda aparição da arraia-miúda estavam juntos, e na terceira eles formavam uma espécie de barreira de passeata já no nível político, já mais juntos no nível político, já se dirigindo diretamente ao público (1973).

O que Peixoto desenhava, o enunciado da encenação que não estava dado na dramaturgia, era uma ascensão da organização do povo. Esse deslocamento operado

\footnotetext{
177 Na edição de 1980 da dramaturgia Calabar esse texto de Peixoto foi incluído em uma versão sintetizada, que (entre outros cortes) não inclui como epígrafe os versos de Cobra de Vidro. Aqui estamos partindo de um texto mais extenso, publicado no livro Teatro em Pedaços. Segundo nota presente no livro, o texto "Uma reflexão sobre a traição" foi escrito para o programa do espetáculo de 1973, publicado no Diário de Notícias do Rio de Janeiro em 4 de novembro de 1973, e na revista Argumento (Rio de Janeiro, $n^{\circ}$ 3) em janeiro de 1974 (1989c, p. 151).

178 No texto “Que pensa você da arte de esquerda?”, de 1968, o próprio Boal fez uma crítica ao que chamou da tendência "sempre de pé" - uma linha maniqueísta e exortativa de teatro, que segundo ele teria validade apenas quando apresentada para o povo. No contexto adequado, a peça exortativa encorajava a luta que ocorria no mundo real. Porém experiências de teatro ligadas à militância foram extinguidas pelo regime civil-militar em 1964, junto com os próprios movimentos sociais. Seguir cantando a Revolução para plateias pagantes de classe média, quando a contrarrevolução preventiva esmagara forças da sociedade organizada, teria algum grau de anacronismo (BOAL, 2016).
} 
pela montagem fica claro ao estudarmos a fala dos dramaturgos sobre a presença do povo na peça, em depoimento concedido ao DCE da PUC:

Chico: O povo está lá. A arraia-miúda está lá. Ela não atua, ela assiste. Mas a intenção é esta. Ela não participa de nada, fica ali perplexa, vendo as coisas mudarem. Prometem reduzir os impostos... O papagaio diz: OBA. Se manifesta assim nessa base: fica triste, fica contente, mas ela não atua para a história.

Ruy: E o Fernando desenvolveu mais isso cenicamente, criando desde o aleijado até passando pelos trabalhadores. Tem todo o desenvolvimento interno dessa arraia-miúda. Nós botamos como uma massa assim, de propósito, anônima, para ser trabalhada durante o espetáculo. (BUARQUE; GUERRA, 1973a, p. 13 -14).

A fala de Chico Buarque descreve uma arraia-miúda perplexa e intencionalmente não participante. Isso não refletia os desejos do artista, mas uma leitura da conjuntura política de horizontes utópicos rebaixados. Já Ruy Guerra colocou a dramaturgia como ponto de partida para uma encenação; no momento da entrevista já estavam ocorrendo os ensaios, e Guerra presenciava os esforços de Fernando em trabalhar o coro.

Vejamos como se davam os três momentos da arraia-miúda mencionados por Peixoto. A participação do coro no espetáculo não se resumia a essas cenas, mas é necessário compreende-las para acompanhar a sistematização do diretor. O primeiro momento, em que eles se dedicariam a trabalhos isolados, ocorria enquanto Mathias escreve a carta a Calabar e até o início da canção Cala a Boca, Bárbara. Ali eles ainda “não eram um conjunto”. A preocupação de Peixoto nesse momento era conseguir “um pouco mais de exagero nos movimentos, quer dizer, teatralizar mais os movimentos de trabalho da arraia-miúda” (1973). A estilização era aqui desejável.

Masetti chama atenção para o tipo de trabalho escolhido para o povo durante os ensaios: "O camarada martelando, trabalhando com o martelo, esse tipo de trabalho mais braçal” (1973). A opção por trabalhos braçais retratados de maneira estilizada favorecia uma aproximação possível entre os trabalhadores do século XVII no Recife e os trabalhadores contemporâneos. A ficção histórica não era rompida, mas a construção de leituras ligadas à realidade de 1973 ainda assim era possível.

A cena culminava na canção, gerando uma ideia fundamental enunciada por Masetti: “Bárbara assumindo Calabar no corpo dela, contrapondo com o povo trabalhando numa situação de clandestinidade, por enquanto” (1973). Nesse momento 
da dramaturgia o herói ainda estava vivo, mesmo que ausente da cena. Peixoto fala desse número como a “canção de amor ao guerrilheiro”.

O uso frequente dessa palavra para descrever Calabar por parte da equipe de direção, dramaturgos e atores envolvidos permite que se faça um paralelo com os guerrilheiros dos anos 1960 e 1970. Alguns grupos envolvidos com a luta armada brasileira adotaram uma estratégia próxima ao foquismo ${ }^{179}$, com inspiração na revolução cubana. Segundo essa estratégia, o levante armado seria iniciado por uma vanguarda e o povo tenderia a aderir, mesmo sem um trabalho político prévio, pois “já estariam amadurecidas condições objetivas para a Revolução na América Latina” (RIDENTI, 2007, p. 25). Mas em Calabar o guerrilheiro já estava sendo perseguido, e o povo, nesse primeiro momento, não corria a pegar em armas e juntar-se a ele. O que o coro sugeria era que sua amada Bárbara se calasse, para se proteger. Pode-se enxergar aqui o povo não participante descrito por Chico. É possível também projetar na cena as divergências internas da esquerda na época. Era o momento de pegar em armas, ou de manter-se vivo durante o refluxo da luta e construir um futuro momento revolucionário?

Mesmo com a dramaturgia indicando um povo que pedia silêncio, Peixoto reforça no diálogo com Masetti um outro trabalho desempenhado pelo coro, além dos trabalhos braçais. Fala de uma figura "limpando armas, que já era uma indicação de uma coisa seguinte. Mas as armas deveriam voltar na cena seguinte. Na última principalmente. Era uma constante que deveria ter se colocado” (1973). No universo ficcional da peça esse indivíduo provavelmente representaria um soldado do acampamento português. Ao mesmo tempo, a figura produzia um vislumbre do povo armado. Também os facões ${ }^{180}$ usados pelos atores que representavam o trabalho com o corte de cana contribuíam para essa “constante”.

O segundo momento chave do coro, no qual eles estariam juntos, ocorria na segunda aparição da oração Miserere. Nesse ponto o Frei e Mathias se retiravam para debater as consequências políticas da confissão de Calabar, já condenado. Peixoto comenta que essa interrupção era das mais difíceis de serem feitas, mas que “a arraia-

\footnotetext{
${ }^{179}$ A organização mais próxima a Cuba no contexto brasileiro foi a Ação Libertadora Nacional (ALN). Mas Ridenti explica que "poucos grupos de esquerda no Brasil assumiram plenamente o modelo cubano" (RIDENTI, 2007, p. 25). A própria geografia brasileira dificultava que um foco de levante armado se espalhasse por todo o território: Cuba é uma ilha, e o Brasil um país de proporções continentais.

${ }^{180}$ Mário Masetti menciona os facões nesse momento do diálogo, concordando com Peixoto em sua ideia de transformar instrumentos de trabalho em armas durante a canção Cobra de Vidro.
} 
miúda estava se saindo até bastante bem”. Masetti afirma que a ideia era boa, e Peixoto descreve:

A ideia é boa. Sobretudo a movimentação do coro no nível da transformação daquela primeira cena. Os caras agora estavam agrupados, mas cada um no seu instrumento de trabalho. E cantando Miserere numa forma carola. E com aquela gesticulação meio biomecanista, sei lá o que era aquilo. Uma gesticulação mais abstrata, onde os gestos que eles faziam quando eles trabalhavam se transformavam em gestos abstratos. Mais coletivos. Era bonito o momento em que a Bárbara saía do meio deles (1973).

A personagem Bárbara se destacava justamente para dizer: "Certo. Certo. / Não tem culpa a arraia-miúda. / Não tem culpa a arraia-miúda. / Arraia-miúda não muda / Arraia-miúda está muda / Carrancuda, tartamuda / Bochechuda, barriguda / Arraiamiúda só ajuda. / A traição graúda" (BUARQUE; GUERRA, 1974, p. 30). Ela também descreve como o traidor "Se esquece espetado em tala / Com que arraia não se rala / E não se fala na sala” (p. 31). O texto da personagem é uma acusação à arraia-miúda. A dramaturgia indica um coro que reza, mas a encenação criou um coro que reza e trabalha. A direção transformou uma massa anônima (nos termos de Ruy Guerra) buscando a piedade divina em uma classe social: trabalhadores com gestos coletivos.

A descrição de sua movimentação como “meio biomecanista” é uma referência à biomecânica de Vsevolod Meyerhold ${ }^{181}$. Essa era uma das inspirações presentes no trabalho do coreógrafo e diretor assistente Zdenek Hampl em seu trabalho com o coro. Zdenek não seguia rigidamente uma única técnica: segundo Anselmo Vasconcelos, ele era uma "enciclopédia de assuntos corporais"182. Vindo da República Tcheca, havia se formado dançarino após oito anos de estudos na Universidade de Praga. Ali reuniu um repertório vasto de referências artísticas, que mobilizava à sua própria maneira no

\footnotetext{
${ }^{181}$ Vsevolod Emilevich Meyerhold (1874 - 1940) foi um homem de teatro russo. No início de sua carreira trabalhou com Constantin Stanislávski. Posteriormente passou a pesquisar uma estética menos ligada ao realismo, e criou a Biomecânica, técnica concentrada na expressividade corporal.

${ }^{182}$ Anselmo Vasconcelos disse na entrevista que Zdenek Hampl era conhecedor de Étienne Decroux, Richard Schechner e Antonin Artaud (mas não mencionou especificamente a biomecânica de Meyerhold). Imara Reis também afirmou: "tinha toda uma dinâmica de corpo que ele trabalhava, que era completamente diferente do que a gente trabalhava aqui no Brasil. Por mais que a gente visse Klaus Vianna, trabalhava consciência corporal, essas coisas. Mas a parte coreográfica do Zdenek era muito interessante". É preciso considerar que certas pesquisas modernas do trabalho teatral europeu e estadunidense chegavam aos poucos no Brasil, e Zdenek foi um dos responsáveis por essas trocas. Por isso faz sentido o termo "biomecanista" aparecer de forma genérica na fala de Peixoto; técnicas estrangeiras modernas de expressão corporal paulatinamente chegavam ao conhecimento dos encenadores brasileiros, e os influenciavam.
} 
momento da criação. Segundo José Lavigne, que foi aluno do coreógrafo no Tablado ${ }^{183}$ : “O que Zdenek fazia tinha biomecânica! Ele não falava assim: 'Olhe, este é um exercício do Meyerhold, a biomecânica...’. Não tinha teoria nenhuma, mas para quem percebia e tinha prazer em estudar ele falava: 'Ih, é isso! Tá aqui neste livro!’” (LAVIGNE apud SIQUEIRA, 2009, p. 64).

Siqueira afirma que, apesar de sua formação acadêmica, Zdenek se orientava por um “pragmatismo pedagógico”, já que mobilizava diversos recursos "buscando alcançar objetivos práticos, em função de uma ideia” (SIQUEIRA, 2009, p. 38). Na cena em que estamos analisando, por exemplo, a ideia a ser perseguida era construir uma movimentação de trabalho coletiva e abstrata, teatralizada.

Vimos como Peixoto já intervira nesse momento da dramaturgia ao trocar de lugar as canções Cala a boca, Bárbara e Tatuagem. A proposta inicial era que o coro em reza se tornasse o coro que pedia para Bárbara se calar. A rubrica da primeira versão do texto indicava: "luz em crescendo sobre os moradores que entoam o refrão do “Miserere Nóbis”; Bárbara vai se destacando dos moradores que vão transformando o refrão anterior no canto “Cala a boca, Bárbara””"184. Peixoto evitou essa transição, que reforçaria a leitura de um povo alienado ${ }^{185}$, desinteressado em participar das questões

\footnotetext{
183 O Tablado foi fundado como uma companhia amadora em 1951, no Rio de Janeiro, por um grupo de artistas e intelectuais. Tornou-se um lugar de referência para o teatro infantil e um centro difusor da dramaturgia de Maria Clara Machado. Na década de 1960 as atividades didáticas ganharam espaço, assim como a encenação de textos adultos. O Tablado é hoje considerado um Patrimônio Cultural do Rio de Janeiro.

${ }^{184}$ Na dramaturgia final editada ainda há mudança entre a reza Miserere (no caso, em sua primeira aparição) e a canção Cala a boca, Bárbara, mas a transição não é gradual. A rubrica sugere um "Corte brusco na música religiosa. Primeiros acordes dolentes para uma nova canção” (BUARQUE; GUERRA, 1974, p. 4). A rubrica é quase idêntica à da primeira versão do texto, quando o Miserere do início da peça se transformaria em outra canção, Tatuagem. Além do corte sonoro brusco, faz diferença que na versão final da dramaturgia essa transição entre reza e imperativo de silêncio ocorra no início da peça, e não no momento em que Calabar está prestes a ser executado (como ocorria na primeira versão textual), o que aumentaria o grau de omissão do povo.

${ }^{185}$ O termo "alienação” é, segundo Raymond Williams, uma das palavras mais difíceis da língua. Em seu livro "Palavras-Chave", ele mostra o desenvolvimento de diversos sentidos diferentes para alienação, partindo de duas ideias fundamentais: (i) "fato de apartar-se ou ser apartado de Deus" e (ii) "ação de transferir a propriedade de algo para outra pessoa". (WILLIAMS, 2007, p. 51). Ele mostra como Marx articulou as duas ideias ao enxergar o processo de alienação como histórico: "o homem cria a si mesmo ao criar seu mundo, mas na sociedade de classes é alienado dessa natureza essencial por formas específicas de alienação na divisão do trabalho, na propriedade privada e no modo capitalista de produção (...). O mundo construído pelo homem confronta-o como estranho e inimigo, e tem poder sobre ele, que transferiu ao mundo seu próprio poder” (p. 54).

Calabar se passa no século XVI, o universo ficcional é pré-capitalista. No entanto, a peça permanentemente construía conexões com 1973. Assim, esse ponto da dramaturgia poderia sugerir a leitura de um povo alienado: havia a presença de um povo miserável que vê em Deus a única possibilidade de salvação, e não enxerga possibilidades de agir no mundo para defender a si próprio e a seu companheiro Calabar.
} 
políticas terrenas. A semelhança entre as melodias do Miserere ${ }^{186}$ e do refrão de Cala $a$ Boca, Bárbara se manteve como memória da proposta dramatúrgica inicial.

O texto de Bárbara tematiza a mudez da arraia-miúda, que instantes antes da execução não intervém em prol de Calabar. Mas a encenação faz desse ponto um salto de qualidade na organização do povo: eles antes trabalhavam isoladamente, e agora se movem como um grupo. Não poderiam salvar a vida de Calabar (isso descaracterizaria completamente a dramaturgia), mas se organizavam para uma possível futura ação.

As palavras ditas por Bárbara eram as mesmas, mas a cena contradizia as acusações da personagem. O povo que ela criticava se mostrava disposto a sair de sua mudez. Chico Buarque afirmou à época que "Bárbara não é só um personagem, como também, volta e meia, ela se dirige ao público, deixando de ser Bárbara, para ser, vamos dizer, o nosso porta-voz” (BUARQUE; GUERRA, 1973a, p. 21). Ao mesmo tempo, ele admitiu os riscos dessa fusão ocasional entre voz dos dramaturgos e voz da personagem: Bárbara “coloca o Calabar como herói, sim, mas acho que isto é normal. A gente não está elogiando Calabar, mas ela está tentando. O papel dela é esse. Por ela ser o personagem, talvez, principal, fica a impressão de que a gente é que está querendo reabilitar Calabar” (BUARQUE; GUERRA, 1973a, p. 22). Os dramaturgos deixavam claro nessa entrevista que não desejavam tornar Calabar um herói, mas sua personagem principal tentava fazê-lo, no mínimo porque o amava.

Analogamente, na cena em que estamos analisando, Bárbara acusava o povo de se omitir frente às injustiças. Ela se destacava do povo em reza para se opor a ele, e denunciar como sua mudez ajudava a "traição graúda”. Seria essa a voz dos dramaturgos? Talvez, já que Chico descreve o povo na peça como perplexo e não atuante. Mas as escolhas da encenação afastaram essa possibilidade. Tornaram Bárbara inconformada com a morte anunciada do amante, mas cega a um povo que já se organizava. Os dramaturgos não pretendiam reabilitar Calabar, mas a encenação possivelmente desejava reabilitar o povo.

O terceiro momento da arraia-miúda era a canção Cobra de Vidro. Ali, segundo Peixoto, a marcação se inspirava em $A$ Mãe, adaptação para o teatro do romance homônimo de Máximo Gorki encenada pelo Berliner Ensemble ${ }^{187}$. A cena da

\footnotetext{
${ }^{186}$ A melodia ficou registrada na fita em que Chico gravou suas composições, um dos lados das duas fitas relativas ao Calabar de 1973 encontradas no Arquivo Fernando Peixoto.

${ }^{187}$ Bertolt Brecht adaptou o romance A Mãe, de Máximo Gorki, para o teatro e Hans Eisler compôs as canções. O espetáculo estreou no Berliner Ensemble em 1951, e a montagem manteve-se no repertório da companhia até a morte de Helene Weigel, em 1971.
} 
paramentação de Bárbara aqui encontrava razão de ser: "ia dar um sentido político muito grande se ela estivesse com um pano vermelho na mão, era exatamente a bandeira vermelha de A Mãe do Gorki” (1973). A imagem de uma mulher empunhando uma bandeira vermelha constava inclusive nos cartazes de divulgação do espetáculo A Mãe, a referência visual foi bastante difundida. Manfred Wekwerth - encenador já mencionado, que muito inspirou Peixoto - realizou uma versão filmada do espetáculo do Berliner Ensemble em 1958. Esse é um dos pontos em que Peixoto anuncia claramente sua inspiração na estética da companhia alemã.

Enquanto Bárbara empunhava o seu pano vermelho, o povo inteiro se organizava em paredão e avançava em passeata (1973). Assim se expressava o ponto máximo de sua organização, o fato de estarem “mais juntos no nível político”. O encenador explica: “Todo mundo deveria estar armado pra passar a ideia de maneira real. Ou transformar os instrumentos de trabalho em armas, ou então ter armas mesmo” (1973). A “constante” do povo armado já apontada por Peixoto se realizava plenamente durante o número Cobra de Vidro.

É possível que a ideia de transformar os instrumentos de trabalho em armas (como por exemplo os facões de corte de cana mencionados por Masetti) objetivasse cenicamente certa leitura da teoria marxista. Que o ser humano aumente as capacidades de seu corpo com utensílios faz parte do seu processo de humanizar-se. Os instrumentos de trabalho permitem que as mãos se prolonguem e se fortaleçam - e junto delas o pensamento e a linguagem. Através do trabalho os objetos da natureza são transformados em objetos da cultura, criando um mundo passível de ser amado. Mas historicamente o trabalho é vivido como exploração; o facão que poderia coletar a doçura da cana para o agricultor é usado principalmente para enriquecer portugueses, espanhóis e holandeses. Na cena vislumbrada por Peixoto, os trabalhadores explorados passariam a utilizar sua força em seu favor. A classe em si se tornaria classe para si, consciente de seus interesses em comum e disposta a lutar por eles. O facão se tornaria arma e os homens, traidores, para fazer chegar o dia em que esse país fosse independente - e a cana adoçasse a vida de quem a cultiva.

Ao descrever a imagem do povo armado, Peixoto justifica que ela existe "para conduzir a ideia que estaria por trás do Calabar revolucionário. Quer dizer: não ele Calabar revolucionário. Mas enfim, a opção brasileira que não existe na peça poderia talvez ser encarnada na arraia-miúda” (1973). O fato de ele se corrigir é relevante. O 
personagem Calabar não era um herói revolucionário como o Zumbi ou o Tiradentes das peças do Arena. Poderia, quem sabe, representar um herói substituível, um guerrilheiro que caiu em combate para que a luta avançasse.

Mas a proposta de Peixoto de encarnar a "opção brasileira” na arraia-miúda encontrava dois problemas, um dramatúrgico e um extra estético. Do ponto de vista da dramaturgia, seria preciso verificar se a imagem do povo em luta ao final seria forte o suficiente para fechar positivamente um texto em que o povo é retratado como perplexo, não atuante, massa anônima (palavras dos dramaturgos). Do ponto de vista do Brasil de 1973 - e talvez também do Brasil de 2019 - caberia se perguntar: a cobra de vidro irá mesmo se refazer? A representação do povo armado em passeata produz uma exortação para a luta a ser realizada no mundo real, ou a sensação melancólica de inverossimilhança?

\section{$\underline{\text { Povo revolucionário e/ou povo contracultural? }}$}

A imagem revolucionária do povo em armas por um Brasil independente era bela e difícil. Faz sentido que Peixoto, formado na perspectiva de uma arte nacional popular e militante do Partido Comunista, desejasse constituir esse vislumbre. Mas a realidade do país e a dramaturgia cheia de contradições dificultava a constituição plena desse momento afirmativo. Ao mesmo tempo, uma outra forma de positividade era nutrida por parte dos artistas envolvidos e se expressava em cena. Diversos atores jovens do coro experimentavam em seu cotidiano a força do pensamento contracultural.

Membros do elenco com seus 18 ou 20 anos de idade (em 1973) haviam saído da infância já em um país sob a Ditadura Civil-Militar. Não puderam viver, como Peixoto viveu, a esperança e os esforços de transformação estrutural ensaiados pelas esquerdas antes de 1964. Mesmo assim, alguns deles se engajaram em movimentos com perspectivas revolucionárias, e até mesmo com a luta armada. Masetti disse do coro que “era um elenco ideologicamente muito forte. Resultou em gente bastante participativa, depois, nas questões da política”188. Dois entre os três atores do coro entrevistados durante a pesquisa eram envolvidos em organizações políticas de esquerda à época.

Havia membros do elenco que conjugavam as duas atitudes: luta pela revolução brasileira (por mais difícil que a causa se mostrasse à época) e experimentação

\footnotetext{
${ }^{188}$ MASETTI, Mário. Entrevista sobre Calabar. Entrevistadora: Nina Hotimsky. São Paulo, nov. 2016.
} 
contracultural. Segundo Imara Reis, em entrevista: "Era o pessoal chamado do desbunde. O pessoal tomava ácido, mas esse povo também era militante. Não era só desbundado. Fazia tudo junto” ${ }^{189}$. A atriz afirmou que essa convergência entre questionamento dos costumes e orientação revolucionária era menos comum dentro do Partido Comunista, que à época nutria um maior moralismo ${ }^{190}$. Mesmo entre os grupos que romperam com o PCB para organizar a guerrilha havia uma dificuldade de conjugar essas pautas. Ainda segundo Imara: "Era um segmento dentro da luta organizada, a gente não era muito aceito não. Porque eles achavam que era um desvio ideológico, que a droga era alienante. A gente achava que não, que era outra manifestação de consciência.”" ${ }^{\text {. O }}$ relato de Imara é importante para evitar uma dicotomização simplista entre os desejos de transformar a estrutura da sociedade e de transformar o modo de vida no presente imediato. Para muitos jovens do início da década de 1970 esses desejos conviviam.

Mas um muro histórico violento barrava as tentativas revolucionárias. Lamarca estava morto, Marighella estava morto, e o último grande levante armado foi massacrado no Araguaia em 1974, menos de um ano após a censura de Calabar. Parte daquela geração impedida de vislumbrar uma revolução social - ao menos em um horizonte próximo - optava por se engajar em um questionamento dos costumes, do modo de vida. A forma de viver teria de expressar, aqui e agora, uma outra forma de ver o mundo ${ }^{192}$. Maciel, estudioso da contracultura já mencionado nesse trabalho, polemicamente afirmava:

O problema não é mais mudar a sociedade - o que é a proposição revolucionária clássica - nem a de resignar-se passivamente às coisas como elas são em busca da salvação interior - o que caracteriza as soluções "puramente pessoais". O problema é de criar uma nova sociedade paralela, com seus próprios valores e suas próprias instituições. Paradise now ${ }^{193}$, o título de um espetáculo do Living

\footnotetext{
${ }^{189}$ REIS, Imara. Entrevista sobre Calabar. Entrevistadora: Nina Hotimsky. São Paulo, ago. 2016.

190 A relação das esquerdas brasileiras a partir de 1961 com a questão específica da droga foi abordada por Júlio Delmanto em sua tese, já publicada em livro. DELMANTO, Júlio. Camaradas caretas - drogas e esquerda no Brasil. São Paulo: Alameda, 2015.

${ }^{191}$ REIS, Imara. Entrevista sobre Calabar. Entrevistadora: Nina Hotimsky. São Paulo, ago. 2016.

192 Claro que o desenvolvimento de tendências contraculturais no Brasil não pode ser visto unicamente como consequência da derrota de iniciativas revolucionárias nacionais. Ele se aliava a tendências mundiais que desde 1968 ganhavam força. Também refletia a insatisfação de setores da esquerda com os caminhos tomados em países que passaram por uma revolução socialista. A divulgação dos crimes de Stalin, por exemplo, gerou um impacto negativo internacional.

${ }^{193}$ Espetáculo apresentado em 1968 no Festival de Avignon, e que depois circulou diferentes países.
} 
Theater, é a palavra de ordem, não para os indivíduos isolados mas para as novas associações comunitárias (MACIEL, 1973, p. 62).

De acordo com essa formulação, Fernando Peixoto estaria mais identificado com a “proposição revolucionária clássica”. Ao mesmo tempo, vimos como estava atento às novas formas de questionamento social que surgiam. Pensador formado na dialética, soube evitar polarizações simplistas. Trabalhava no Teatro Oficina quando Zé Celso iniciou sua guinada contracultural; rompeu com Zé Celso homenageando-o, ao incluir em seu Don Juan um coro desbundado. Naquela peça discutiu "o furo da revolta pequeno-burguesa individualista” - o mesmo furo que Maciel admite ao criticar as soluções “puramente pessoais”. Peixoto ficou fascinado pela profundidade da pesquisa estética de Kerensky e dispôs-se a debater com o jovem encenador em duas críticas, nas quais respeitosamente sugeriu a necessidade de levar em conta questões políticas e econômicas no palco (mesmo ao pesquisar processos inconscientes). Escreveu em 1973 um texto discutindo “Uma nova consciência no teatro brasileiro?”, com título inspirado pelo livro de Maciel e um subitem dedicado a refletir sobre a existência de um teatro de contracultura (PEIXOTO, 1989b).

Ao escrever sobre esse teatro de contracultura almejado por certa juventude da época, Peixoto também utiliza muitas vezes a expressão “até que ponto” - a mesma que é recorrente na fita em que refletiu sozinho sobre Calabar. Essa é uma maneira de formular suas críticas de caráter teórico e político, sem com isso desmerecer completamente as pesquisas estéticas de uma nova geração, que de todo o modo expressava descontentamento com o status quo. Ele começa se perguntando até que ponto o encenador polonês Jerzy Grotowski (um dos artistas que mais influenciou esse teatro) teria algo a contribuir com a realidade latino-americana. Alerta que "para muitos, Grotowski é uma praga que desvia a juventude do confronto com a realidade sociopolítica de seus países, conduzindo-a ao confronto, menor, do indivíduo consigo mesmo” (PEIXOTO, 1989b, p. 146). Países com desigualdades sociais profundas para resolver talvez não pudessem se dar ao luxo de uma arte tão implicada em questões privadas.

É provável que Peixoto estivesse dialogando com Augusto Boal ${ }^{194}$, que em texto produzido em Buenos Aires em março de 1973 escreveu:

\footnotetext{
${ }^{194}$ Devo essa observação ao professor Sérgio de Carvalho, que notou a relação entre o texto de Peixoto e o de Boal e me indicou o livro "Técnicas Latino-Americanas de Teatro Popular". Agradeço ao professor por mais essa contribuição.
} 
O colonialismo cultural, é tão cotidiano, tão persistente, que já se tornou invisível, passa desapercebido. (...) Parece-nos muito natural que se formem grupos de estudos para praticar as técnicas de Teatro Laboratório de Vroclav, Polônia, mas nos pareceria muito estranho pedir a Grotowski que montasse um espetáculo sobre a reforma agrária. Esta última hipótese é absurda: as técnicas de Grotowski servem aos espectadores de Grotowski e, da mesma maneira, os artistas que trabalham com um público que necessita da reforma agrária têm que desenvolver as técnicas indispensáveis para montar peças sobre a reforma agrária. É uma estupidez imensa e sem-fim, pensar que alguns temas como, por exemplo, o "subconsciente coletivo" é "arte", enquanto a reforma agrária é "política". Poderíamos responder lembrando que a reforma agrária é arte e o subconsciente coletivo é psicologia (BOAL, 1979, p. 91).

Para Boal, o fascínio por Grotowski na América Latina expressaria o domínio de ideias colonizadoras nos países colonizados. Isso, em um tempo em que ele acreditava estar próxima uma "revolução copernicana ao contrário": o momento em que os povos da América Latina se descobririam como sujeitos da história, como centro, e não mais satélites. Essa esperança tinha como lastro recente a Revolução Cubana, além de movimentos populares que se desenvolviam no Peru, Panamá e Argentina. Os imperialistas, observando o levante dos povos dominados, estariam lançando contra eles “todas as armas de sua cultura e, pior ainda, toda a sua cultura” (BOAL, 1979, p. 90). Seria, portanto, o momento de o teatro latino-americano travar uma batalha contra o teatro colonialista.

Peixoto (ainda que provavelmente concordasse com diversos argumentos de Boal) ${ }^{195}$ expressou sua discordância a respeito de Grotowski: "Colocar Grotowski como uma influência nefasta é uma maneira fácil e infantil de enfrentar o problema. Seu teatro é fundamental neste século, sua presença é uma afirmação histórica vigorosa” (PEIXOTO, 1989b, p. 147). Para ele, as influências estrangeiras não deveriam ser genericamente rejeitadas, e sim assimiladas de forma crítica (p. 146). Peixoto menciona a ideia de Antropofagia - artistas brasileiros poderiam “comer” as mais diversas ideias estrangeiras, e vomitar o que não lhes interessasse.

Essa defesa é realizada em diálogo explícito com Luiz Carlos Maciel, referência intelectual dos interessados pela contracultura: “O próprio Maciel, mesmo quando afirma que está fadada ao fracasso qualquer aspiração a cultura nacional com a pureza

195 No final da década de 1970, Fernando Peixoto escreveu o prefácio do livro "Técnicas LatinoAmericanas de Teatro Popular”, de Augusto Boal. Nesse livro foi publicado, como apêndice, o texto "Uma revolução copernicana ao contrário”, de onde foi extraída a menção de Boal a Grotowski. 
preconizada por um Gramsci, não deixa de ressaltar que só as raízes nacionais podem propiciar energia e originalidade criadora a uma cultura” (PEIXOTO, 1989b, p. 146). Subjaz a esse trecho uma discussão sobre o nacional popular. Maciel admitia que as raízes nacionais eram fundamentais para a cultura brasileira, e Peixoto admitia que as influências estrangeiras poderiam ser importantes, desde que apreendidas de maneira crítica. Ambos os pensadores se dispunham a defender suas ideias sem ignorar as contradições, e sim lidando com elas.

Ainda ao discutir um teatro de contracultura, Peixoto levanta outros "até que pontos":

Até que ponto estes espetáculos se afastam da análise da realidade nacional e terminam numa contemplação passiva, abstrata, antihistórica, individualista e inútil, demitindo o teatro de sua responsabilidade social. Cumpre mesmo verificar até que ponto o teatro tem o dever, preconizado neste século sobretudo pelas formulações fundamentais de Brecht, de assumir seu papel na transformação do homem e da sociedade. (...) Até que ponto este mergulho desenfreado nas insondáveis camadas irracionais do ser humano não passa de um fascinante capítulo da própria racionalidade do homem? Porque tudo isso acontece no mundo hoje e encontra entusiasmo e entrega também no Brasil de hoje? Até que ponto, como afirma Maciel a respeito da contracultura (não sem antes dizer que não concorda com tudo que ela vem estabelecendo), este teatro não constitui um saudável arejamento dos nossos hábitos mentais e de nossas categorias de pensamento? Ou, ao contrário, não passa de uma atitude elitista, alienada e mistificadora, fuga de um confronto com os problemas efetivos do homem e da sociedade? Pessoalmente a pesquisa de um indivíduo isolado do contexto sócio-econômico em que vive me parece uma postura inútil e frequentemente mentirosa como processo de conhecimento da verdade. Mas na medida em que esta análise é realizada, até onde possui utilidade e sentido? São inúmeras interrogações que somente a verificação descontraída e isenta de preconceitos pode dar respostas válidas (PEIXOTO, 1989b, p. 147).

Esse trecho conjuga ao menos três aspectos relevantes. Em primeiro lugar há uma preocupação política com o estabelecimento de um teatro não implicado com a realidade social. Essa fala liga Peixoto à sua geração de artistas: uma geração que vislumbrou a perspectiva de reformas de base que construiriam um Brasil mais justo, e agiu para que a arte estivesse também dedicada à transformação da sociedade. Em segundo lugar, há uma percepção de que alguns fundamentos teóricos da contracultura estariam mal formulados. Isso fica claro no trecho em que ele levanta que o mergulho no irracional faz parte da própria racionalidade. Por fim, há uma crítica sobre a própria crítica: o autor se pergunta qual a utilidade de sua análise, e se abre para conhecer as 
peças e as falas de alguns jovens artistas. A verificação isenta de preconceitos é uma tentativa que se expressa em todo o restante do texto, quando Peixoto assiste às peças ligadas ao teatro marginal e entrevista seus criadores. Afinal, diferentes propostas de teatro "somente adquirem significados quando estudadas a partir de uma prática efetiva. Aqui o que nos interessa, sobretudo, é a divulgação de parte deste esforço dos mais jovens, utilizando inclusive, no nível da informação, suas próprias declarações de princípios” (p. 148).

No mesmo mês em que Peixoto exercia sua atividade de crítico pesquisando um teatro de contracultura, ele atuava como artista dirigindo Calabar. A fita que gravou sozinho reforça uma convivência instigante entre a crítica política e teórica à contracultura e o interesse por certas práticas teatrais ligadas a ela:

Até que ponto também com essas pesquisas feitas com esses grupos jovens eu não estou esbarrando com outra mentalidade de pensar que está me problematizando, na medida em que está primada em outras coordenadas. Essa semana não só o encontro com outros espetáculos, alguns dos quais minha capacidade crítica se exerceu sem problemas, mas diante do espetáculo do Kerensky a minha capacidade crítica não se exerce sem problemas, porque o espetáculo me toca. Me toca no nível de me colocar problemas. Isso é a coisa mais importante que aconteceu. Até que ponto também a leitura do livro do Maciel "A nova consciência”, embora seja um livro que eu li com a maior facilidade, que não me causou nenhum tipo de perplexidade, com seu próprio fascínio pela lucidez com que ele Maciel consegue defender ideias que eu absolutamente discordo, mas a capacidade também contraditória que ele tem, de às vezes ser um analista lúcido e quase dialético. Até que ponto esse encontro com toda uma juventude inquieta do momento não deve provocar em mim justamente - e isso seria muito positivo - uma reformulação de uma linguagem teatral que eu estaria realizando (1973c).

Ao falar da juventude inquieta, Peixoto poderia estar se referindo mais diretamente às suas pesquisas como crítico teatral. Mas certamente havia também na equipe de Calabar uma juventude inquieta que participava do coro. Em entrevista concedida a Rosângela Patriota, Peixoto (2001) elogiou: “percebi que o elenco ${ }^{196}$ estava com uma capacidade de entender o texto muito grande. Coisas que eu até pensei que iam ser difíceis de explicar, eles estavam seguindo muito bem de modo geral e até

\footnotetext{
${ }^{196}$ Ao falar sobre os atores, é provável que ele se referisse igualmente a coro e a protagonistas. Como vimos em outra declaração da mesma entrevista: "A relação de um com o outro era trabalhada em todos os detalhes, quer dizer, se trabalhava igual. (...) Não havia para nós a diferença entre o chamado "elenco" que faz aqueles personagens todos e a "figuração" digamos, que faz o povo". (PEIXOTO, 2001).
} 
contribuindo nas discussões”. Essa era a visão do diretor sobre a sala de ensaio democrática descrita por Imara Reis.

O artista diferenciava sua capacidade crítica em relação às formulações de Maciel e em relação à obra de Kerensky, já que seus espetáculos o tocavam. A teoria em torno da contracultura se mostrava questionável, mas alguns artistas jovens traziam provocações instigantes para o trabalho de Peixoto. O diretor estava orientado por pressupostos materialistas e pelo método dialético, e não poderia concordar com certos ídolos da contracultura quando estes se diziam contra qualquer forma de organização política, acreditando que a Revolução se faria sozinha (HAVENS apud MACIEL, 1973, p. 158). Mas mesmo uma encenação que retratava a crescente organização do povo, como Calabar, poderia se beneficiar da atitude experimental nutrida pelas novas gerações. Do ponto de vista das relações de trabalho, uma superprodução escrita e dirigida por artistas de esquerda poderia se inspirar no trabalho teatral coletivizado experimentado pelos grupos jovens. Essas atitudes poderiam favorecer os projetos artísticos de Peixoto: uma renovação da linguagem ${ }^{197}$ pautada em um aprofundamento das pesquisas em torno da teatralidade..

\section{$\underline{\text { Povo em festa }}$}

Mas como a atitude contracultural se expressava na sala de ensaio e na encenação de Calabar? De que maneira ecoava ou produzia dissonâncias em relação à dramaturgia? E como Peixoto avaliava essa presença? Uma chave para essas questões é estudar o trabalho do coreógrafo e diretor assistente Zdenek Hampl. Atores do coro entrevistados para a presente pesquisa descreveram com muita admiração o trabalho de Zdenek. Falaram de seu profundo conhecimento de técnicas corporais, aliado a um incentivo alegre à improvisação dos atores.

Anselmo Vasconcelos disse que a função de Zdenek ia além da coreografia (compreendida como a organização de uma dança, ou da movimentação dos artistas durante a execução de uma música), que se tratava de uma corpografia ${ }^{198}$. O termo,

\footnotetext{
197 Essa busca era influenciada pela ideia de revisionismo brechtiano, à época debatida na França: o encenador afirma na fita que gostaria de fornecer sua contribuição pessoal para esse revisionismo (1973). ${ }^{198}$ Hoje em dia o termo corpografia também está sendo utilizado com outra acepção: "A corpografia é um conceito elaborado por Paola Jacques e Fabiana Britto, por meio de referências da Dança e da Arquitetura, com o intuito de construir uma alternativa à ideia de "cidade espetáculo" (Guy Debort, 1997) (...) a corpografia se traduz num modo diferenciado de sentir a cidade por meio de intervenções e performances estéticas e artísticas que provocam, rechaçam, questionam a espetacularização das
} 
mais amplo e mais moderno, coincide com a maneira pela qual Zdenek é creditado na ficha técnica do trabalho seguinte que realizou com Peixoto, A torre em concurso (1974). Sua criação de uma linguagem corporal poética parecia ter a confiança de Peixoto, que não sentia a necessidade de intervir demais - tanto que não lhe era importante definir com precisão a técnica utilizada ${ }^{199}$. Na entrevista concedida a nós, Masetti também falou com muito entusiasmo do processo criativo de Zdenek.

É curioso que a fita de diálogo sobre o espetáculo tenha sido gravada entre Peixoto e Masetti, sem a presença do outro diretor assistente ${ }^{200}$, Zdenek Hampl. É possível que a língua fosse ainda um pequeno entrave - o dançarino vivia no Brasil há apenas três anos. Mas uma hipótese plausível é que, embora Zdenek fosse fundamental para o trabalho com o coro, sua pesquisa em torno da expressão corporal estava menos afinada com as concepções gerais de Fernando Peixoto. Ou, no mínimo, seu pensamento sobre a criação se expressava em outros termos. Em livro publicado sobre Zdenek Hampl, que inclui relatos de diversos artistas que trabalharam com ele ${ }^{201}$, em nenhum momento são mencionados termos como Bertolt Brecht, teatro dialético, materialismo. Essa diversidade possivelmente produziu alguns ruídos interessantes para a montagem.

A ameaça da censura levou à decisão de que Zdenek, Caymmi e Masetti ensaiassem mais com os atores do coro, enquanto Peixoto se dedicava aos protagonistas. Nina de Pádua, atriz do coro, descreveu: "Fernando trabalhava os personagens principais, Mário fazia o entremeio, e Zdenek era quem mais trabalhava com a gente. Porque ele precisava de movimento, de corpo(...). A gente trabalhou muito mais com Dori e Zdenek do que com o Fernando”202. Essa divisão - que já se praticava desde o início, mas foi intensificada para garantir que a peça ficasse pronta - pode ter dificultado um diálogo mais orgânico entre o diretor e sua equipe. A forma de produção de Calabar já determinava que o período de ensaios fosse curto, mas a reta final foi

metrópoles contemporâneas". Silvana Nascimento, « A cidade no corpo », Ponto Urbe [Online], 19 | 2016, posto online no dia 31 dezembro 2016, consultado o 01 maio 2019 . URL: http://journals.openedition.org/pontourbe/3316 ; DOI : 10.4000/pontourbe.3316

199 Vimos como se referiu à determinada movimentação como "meio biomecanista".

200 Zdenek foi inicialmente contratado como coreógrafo. No texto em que Peixoto narra os passos da produção, "Histórico de um Aborto”, ele aparece designado para essa função (PEIXOTO, 1989c, p. 159). Masetti afirmou: "Eu acho que eu ganhei o título de diretor assistente pra esse coreógrafo poder também ganhar o título. Porque ele era muito bom. Era o Zdenek”. MASETTI, Mário. Entrevista sobre Calabar. Entrevistadora: Nina Hotimsky. São Paulo, nov. 2016.

201 Trata-se do livro: SIQUEIRA, Arnaldo (org). Zdenek Hampl - Perfis de um artista inovador. Recife: Ed. Do Organizador, 2009.

${ }^{202}$ PÁDUA, Nina de. Entrevista sobre Calabar. Entrevistadora: Nina Hotimsky. Rio de Janeiro, jan. 2018. 
prejudicada pela incerteza de que teriam permissão oficial para estrear. A sensação de Peixoto de que gostaria de trabalhar mais o Povo está ligada à organização dos ensaios, decidida não unicamente por uma escolha artística, mas sim em função da necessidade prática de finalizar a encenação. Segundo Masetti, a tentativa era deixar o espetáculo pronto para garantir sua versão filmada, caso a censura impossibilitasse a temporada da peça $^{203}$.

Quais as reflexões de Peixoto sobre o trabalho de Zdenek? Nas fitas analisadas o diretor só o menciona nominalmente em uma ocasião, quando afirma que “a orgia funcionava muito bem, por causa da marcação do Zdenek” (1973). Ele se refere à cena do banquete holandês. Apesar do elogio, acrescenta uma ideia que não chegou a realizar: "Podia talvez se utilizar gente passando com sacos de açúcar por trás da cena. Para não mostrar só a orgia, mas mostrar que por trás daquela orgia tinha uma movimentação de trabalho e de saque. Quer dizer, o açúcar sendo transportado por escravos” (1973). Mesmo avaliando a eficiência da marcação, o diretor sentia falta de um elemento material que inserisse o banquete em determinada situação social. Os participantes da festa eram colonizadores que comerciavam riquezas produzidas em um Brasil escravocrata.

Vimos como essa ideia ocorria a Peixoto desde o primeiro estudo da dramaturgia, antes do início dos ensaios. O que lhe incomodava nesse ponto da peça, em última instância, não era o trabalho do coreógrafo e sim a própria dramaturgia, que não detalhava com rigor o contexto socioeconômico da ação dramática. Os holandeses em festa poderiam produzir uma espécie de alegoria do colonizador, mais do que uma análise profunda do processo de colonização. Na fita que gravou sozinho o diretor deixa claro esse seu impasse na relação com a dramaturgia. Afirma que em Calabar

a reflexão histórica é entremeada de superficialidades, a reflexão histórica é pouco minuciosa quanto a uma análise marxista dessa realidade. Até que ponto isso realmente constitua um freio que eu talvez não tenha sentido em outros espetáculos feitos anteriormente porque o meu grau de capacidade para compreensão disso não tenha existido. Talvez também porque eu não tenha repensado espetáculos já feitos dentro dessa perspectiva. (...). Agora, talvez porque eu tenha

\footnotetext{
203 “Na verdade o espetáculo, ele não estava totalmente pronto quando foi proibido. E pra gente filmar eu lembro que a gente fez um tour du force assim, de falar "vamos terminar o espetáculo!”. Então eu fiquei meio cuidando de toda a figuração, disso eu lembro bem, e dos movimentos de cena, enquanto o Fernando ensaiava com os atores principais, pra gente ter um espetáculo pronto. Enfim, estava semipronto". Vimos que ao final a própria filmagem da peça foi impossibilitada. MASETTI, Mário. Entrevista sobre Calabar. Entrevistadora: Nina Hotimsky. São Paulo, nov. 2016.
} 
realizado um trabalho mais maduro meu, evidentemente as questões que se colocam pra mim mesmo são questões mais graves (1973c).

A dramaturgia não se propunha a realizar uma análise marxista daquele período da colonização do Brasil. Tampouco fazia um puro elogio da festa, do corpo, da contracultura. Sugeria, sim, diversas cenas festivas, mas a festa geralmente era criticada pelo próprio texto. A orgia holandesa mostrava a riqueza ostensiva dos colonizadores; a festa em comemoração à vitória da batalha de Porto Calvo vinha com a violência imposta à Anna de Amsterdam, tratada como despojo de guerra. As comemorações em torno de Maurício de Nassau (em sua chegada e no momento da inauguração da ponte) mostravam um povo facilmente manipulável por um líder populista. O “momento de festa” assegurado por Nassau era traído pelo próprio governante, quando saía de cena “cantando seu sonho colonialista” (PEIXOTO, 1989c, p. 156). A canção final, Elogio da traição, era pura ironia. Cantava-se animadamente como o que é bom para a Holanda (e Espanha, e demais países) é bom pro Brasil.

Peixoto comentou sobre essa última cena: "Tinha que ser um desbunde total, como no final da semana. E mais irônico, mais cínico. Eu acho que faltava isso às vezes no coro, o cinismo, a ironia, a inteligência cínica” (1973). Aqui o diretor coloca o desbunde a serviço da ironia. Essa postura seria uma demanda da própria dramaturgia, e especialmente das canções. Podemos sistematizar as canções cantadas pelo o coro em alguns gestos. Há o gesto de procurar na religião uma salvação possível, em Miserere Nóbis. O gesto de cuidar de Bárbara, em Cala a boca, Bárbara. As canções de orgia (os coros para frases musicadas durante a apresentação de Anna de Amsterdã) e de festa e comemoração a Nassau, Não existe pecado do lado de baixo do Equador e Boi voador não pode. As canções de ironia, Vence na vida quem diz sim e Elogio da traição (essas duas não dependem da relação com a dramaturgia, são claramente irônicas por si mesmas). E uma única canção de luta ${ }^{204}$ : Cobra de vidro.

Ao analisar a obra de Chico Buarque, Meneses dedica grande atenção à ironia, linguagem "que desvenda a ideologia, que desnuda: a linguagem 'faca só lâmina"” (1982, p. 168). Marcos Napolitano também observa na obra de Chico a oscilação entre “melancolia crítica e euforia irônica” (2010, p. 392). É uma constante em Calabar que músicas festivas e animadas carreguem letras que dizem o contrário do que se quer

204 Ou “canção de repressão”, como propõe Meneses (1982, p. 81). Essa formulação será abordada mais adiante. 
expressar. Dizendo diretamente: o que é bom para a Holanda não é bom para o Brasil. Não vence na vida quem diz sim. Não mande prender o boi voador!

Um possível problema para o diretor: um coro festivo que reiteradamente canta o contrário do que os dramaturgos diriam poderia endossar a imagem (já assumida por Chico Buarque) de um povo que não atua para a história. Um povo que canta e dança sem perceber que está sendo explorado. Um momento do coro que incomodava Peixoto, aliás, era o número do boi voador: “O boi voador tranquilo, era gostoso, o boi voava bonito. (...) Eu não sei se... Mas isso é meio inevitável, nesse tipo de musical. O texto não propõe outra coisa. O povo meio se perdia, ficava meio coreografia” (1973). A marchinha carnavalesca, gênero musical reconhecível, parece ter sido coreografada por Zdenek de forma a manter seu sentido de dança comemorativa. O trabalho corporal não produziu contradição em relação à musicalidade festiva. Tampouco os objetos de cena criaram ruídos, pelo contrário: o boi constituía segundo Masetti um "espetaculão popular”205, com sua barriga que abria e deixava cair confetes.

Os figurinos também se tornavam mais coloridos desde a instauração do governo holandês no Brasil. Para Masetti, com a chegada dos holandeses o espetáculo "virava um Teatro de Revista mesmo. Muito próximo do Teatro de Revista. Porque era o discurso otimista do Nassau, era a festa do boi voador... Os figurinos dos camponeses faziam uma releitura colorida dos tempos lusitanos, que eram mais sombrios”206. O trabalho de Rosa Magalhães, carnavalesca que criou os figurinos em parceria com Helio Eichbauer, aqui servia para melhor constituir a alegria “revisteira” e algo ingênua de um povo que via na gestão desenvolvimentista a esperança de uma realidade social mais justa.

205 O uso do termo "popular" abriria margem para debates mais aprofundados sobre a relação dos artistas e intelectuais brasileiros de esquerda com a arte popular. Como vimos, essa foi uma questão essencial durante as décadas de 1950 e 1960, quando se buscou uma arte "nacional e popular". Não será possível ir muito adiante nesse debate nos limites deste trabalho. Fica para registro a descrição completa de Masetti a respeito do boi voador.

Mário - Tinha um boi que voava.

Nina - Como ele era feito?

Mario - Era um boizão de madeira...

Nina - Madeira?

Mario - Forrado com pele de boi. E no meio do caminho tinha umas cordas, uns cordéis assim. Ele abria a barriga, caía confete... Espetáculão né, popular.

MASETTI, Mário. Entrevista sobre Calabar. Entrevistadora: Nina Hotimsky. São Paulo, nov. 2016.

${ }^{206}$ MASETTI, Mário. Entrevista sobre Calabar. Entrevistadora: Nina Hotimsky. São Paulo, nov. 2016. 
Há uma proximidade histórica entre a estética do Teatro de Revista brasileiro e a estética do carnaval ${ }^{207}$ - especialidade de Rosa Magalhães. Em ambos os fenômenos, é frequente que a crítica social (quando há) conviva com o deslumbramento e a alegria. O coro que dançava e cantava com seus trajes coloridos contribuía para a representação do povo do Recife no século XVII? Ou para a constituição de analogias com o povo brasileiro em 1973? Ficaria a cargo dos espectadores de Calabar ler criticamente a festa constituída em torno de Nassau. O governante, afinal, trazia algumas melhorias para a cidade, mas não deixava de ser um representante dos interesses econômicos da Holanda. Quando se afastava desse foco, rapidamente o Consultor vinha lhe corrigir.

É possível que problemas estéticos parecidos tenham se dado em um ponto anterior da peça, em torno do número Não existe pecado do lado de baixo do Equador (embora Peixoto não tenha expressado o mesmo incômodo que formulou ao falar do Boi voador $^{208}$ ). Musicalmente tratava-se de um frevo, e como tal foi coreografado por Zdenek. O frevo irrompia logo após a chegada dos holandeses no Brasil, produzindo uma transição bem-humorada. A chegada de Nassau se dava enquanto o cenário se transformava, com a inclusão de um carro, bandeiras e cores. Entrava a corte, e em seguida o povo:

Aqui sim eu achava bacana. Era meio Debret ${ }^{209}$ o povo entrando e começando a caminhar, aquela espécie de praça pública, dava um retrato do país. Eu não sei se eu não devia ter trabalhado o povo no sentido da guerra. Nas cenas anteriores, do acampamento. Agora, faltava gente também, teria de fazer com o dobro [de atores]. Essa cena eu acho que era bonita porque preenchia o palco inteiro. (...) A explosão do frevo era muito gostosa!

O frevo vinha para interromper a instauração solene de um governo holandês no Brasil. Traços historicistas da encenação ${ }^{210}$ - como a execução do hino holandês, a

\footnotetext{
${ }^{207}$ As pesquisas de Neyde Veneziano, Flora Sussekind e Salvyano Cavalcanti de Paiva oferecem mais informaç̃oes sobre as diferentes fases do Teatro de Revista brasileiro e sua relação com o carnaval.

${ }^{208}$ A respeito de Não existe pecado do lado de baixo do Equador Peixoto comenta: "A explosão do frevo era muito gostosa” (1973). Essa canção fazia a transição do primeiro ato para o segundo ato, e vinha antes de Boi voador não pode. Talvez o incômodo de Peixoto com um "povo que se perdia" no momento do boi voador também tenha se dado pela reiteração de momentos carnavalescos ao longo do segundo ato.

${ }^{209}$ Peixoto se refere ao pintor francês Jean-Baptiste Debret, que realizou viagens ao Brasil no Século XIX e publicou desenhos registrando sua estadia no país em 1831, no livro "Viagem pitoresca e Histórica ao Brasil”. Há também uma referência a Debret em seu caderno de direção, e data do dia 26 de Julho de 1973. (PEIXOTO, 1973a).

210 É possível que Peixoto se inspirasse no encenador francês Roger Planchon (1931 - 2009) ao valorizar a constituição em cena de um quadro histórico detalhado. Planchon já havia operado a politização de textos clássicos (como os de Molière) a partir desse mesmo recurso. Ao incluir na encenação de Jorge Dandin figuras populares pouco desenvolvidas pela dramaturgia original, Planchon permitia que o espectador criticasse a estrutura social que envolvia as situações cômicas da peça. Segundo Roubine, ao
} 
referência visual pautada em Debret e a preocupação em constituir um “retrato do país” - cediam lugar a uma vivaz manifestação popular brasileira. Zdenek afirma ter se dado ali seu primeiro encontro com a cultura nordestina, justamente a partir desse ponto da peça: “Não existe pecado do lado de baixo do Equador. E eu: Meu Deus, o que vou fazer? Coreografava muito bem, mas não sabia nada de frevo, nada de nada. Como Chico Buarque vai me olhar se eu não conseguir? Então me virei, fiz do jeito que podia” (HAMPL, 2004). Pouco tempo depois o dançarino foi viver no Recife, e passou a estudar profundamente as danças populares brasileiras ${ }^{211}$.

Qual parcela de crítica aos colonizadores seria transmitida nesse momento? E em que medida a alegria da música e da dança se imporia aos debates materiais? É impossível mensurar ao certo, mas trata-se de todo modo de um problema. Vimos como a letra de Não existe pecado do lado de baixo do Equador é baseada em um ditado que circulava entre os colonizadores, autorizando-os moralmente a agir como bem quisessem fora da metrópole. Segundo a leitura de Rocha (2006), a carnavalização de um ditado dos poderosos se tornaria forma de resistência.

Os números Boi voador não pode e Não existe pecado do lado de baixo do Equador (uma marchinha e um frevo) tem seus gêneros musicais diretamente ligados à tradição do carnaval brasileiro. A inspiração no Teatro de Revista, abraçada pela dramaturgia e pela encenação, reforça em Calabar uma forma de crítica que parte do humor, da festa, da irreverência. Tornar o poder risível é uma maneira de questioná-lo, e de abrir espaço para imaginar outra forma de viver. Rocha, em sua análise da dramaturgia, desenvolveu essa abordagem orientada por pressupostos de Mikhail Bakhtin $^{212}$ : “O procedimento da carnavalização, além de mostrar o lado oculto e escuso do discurso oficial, também revela a possibilidade de um futuro diferente” (2006, p. 145). De todo o modo, assistir a um número de frevo coreografado no palco de um teatro é diferente de viver nas ruas - e no próprio corpo - a experiência do carnaval. A fronteira entre força de rebeldia da cultura popular e neutralização da crítica é delicada.

Peixoto adiciona um dado significativo ao ver a coreografia se impor - e o povo se perder - em certo “tipo de musical”. A que tipo de musical ele se referia? Embora os

comentar a encenação de Jorge Dandin de 1958, Planchon "substituía o habitual enfoque de farsa da infidelidade conjugal por uma representação dos conflitos de classe do século XVII” (ROUBINE, 1998, p. 201).

211 Segundo ele: "Mas depois quando pisei aqui [no Recife] a primeira coisa foi: Quero conhecer frevo! Maracatu, Caboclinho”. HAMPL, Zdenek, 2004.

${ }^{212}$ Mikhail Bakhtin, filósofo russo, desenvolveu o conceito de "carnavalização" a partir dos estudos da cultura popular na Idade Média. 
dramaturgos dialogassem com a tradição do Teatro de Revista, o modelo da Broadway já era importado ao Brasil na época ${ }^{213}$. Um dos recursos tradicionais dessa forma hegemônica é a presença de um ensemble, espécie de coro que canta, dança e dá suporte para os protagonistas. Subjaz a essa forma ${ }^{214}$ o entendimento de que a ação do protagonista é o que realmente importa; não caberia a um ensemble tradicional a tarefa de figurar o povo enquanto categoria política. O espectador de musicais da Broadway (e de outros produtos análogos) é visto como um consumidor que deve ser agradado $^{215}$, e não como um interlocutor com o qual refletir sobre a realidade social. É possível que os números de dança e música mais tradicionais em Calabar gerassem um conforto de leitura nos espectadores, que poderiam lidar com eles a partir de um modelo de recepção hegemônico, pouco crítico.

Mas o trabalho de Zdenek não se bastava em coreografias tradicionais de gêneros brasileiros consagrados. Vimos que Peixoto fala de uma movimentação "meio biomecanista” do povo, que operava o salto de trabalhos individuais para a consolidação de um coletivo de trabalhadores. O discurso de organização da classe trabalhadora constituído pela encenação foi materializado inclusive através dos recursos de expressão corporal trazidos por Zdenek.

Já Masetti lembra que o coreógrafo produzia um “movimento de guerrilha no palco” ${ }^{216}$, com atores escalando as cordas que integravam o cenário. Mais uma vez a palavra guerrilha foi associada a Calabar. Na dramaturgia as batalhas entre portugueses e holandeses são apenas mencionadas verbalmente pelos personagens, e não surgem propriamente como ação. Mas os relatos dos artistas envolvidos indicam que o

\footnotetext{
213 Basta lembrar a montagem de $O$ homem de la mancha de 1972, e a proibição dos produtores estadunidenses a respeito de mudanças na encenação. Como definiu Peixoto, "o espetáculo pertence ao universo do comércio teatral” (2002, p. 188).

${ }^{214}$ Parte-se da compreensão de "forma como conteúdo "precipitado". A metáfora expressa ao mesmo tempo o caráter duradouro da forma e sua origem no conteúdo, ou seja, suas propriedades significativas" (SZONDI,2001, p. 25). O enunciado formal de determinada obra ou gênero está ligado ao enunciado do conteúdo. Existe também "a possibilidade de que o enunciado do conteúdo entre em contradição com o da forma” (SZONDI, 2001, p. 25).

${ }^{215}$ Bertolt Brecht escreveu muito sobre o efeito que o teatro exerce nos espectadores. Ele observou um modelo teatral hegemônico em sua época, que segundo ele gerava um estado de enlevo, fascinação passiva. Um "velho tipo de diversão, que constituía um alívio para o seu dia-a-dia” (BRECHT, 2005, p. 140). Contra esse modelo, propôs que o teatro desenvolvesse um novo tipo de diversão. "Um dos prazeres específicos da nossa época, que tantas e tão variadas modificações efetuou no domínio da Natureza, consiste em compreender as coisas de modo que nelas possamos intervir. Há muito de aproveitável no homem, dizemos nós, poder-se-há fazer muito dele. No estado em que se encontra é que não pode ficar; o homem tem de ser encarado não só como é, mas também como poderia ser”. (BRECHT, 2005 p. 147). Essa formulação provavelmente animava Peixoto, quando este imaginava os efeitos de Calabar sobre seus espectadores.
}

${ }^{216}$ MASETTI, Mário. Entrevista sobre Calabar. Entrevistadora: Nina Hotimsky. São Paulo, nov. 2016. 
espetáculo iria retratar a guerra em cena. Havia festa e havia luta. Um dos momentos lembrados com mais detalhes pelos atores do coro entrevistados, e também discutido por Peixoto e Masetti, foi a cena da invasão (assim nomeada pelos entrevistados, que também se referiram a ela como “invasão de Porto Calvo”, “invasão holandesa” e “batalha”). Sua criação foi orientada por Zdenek. Anselmo descreveu: “o Zdenek sugeriu pra gente um moto-contínuo. Você era português, então você morria, passava a ser holandês; atacava, aí você passava a ser índio. Isso tudo em cena, com trocas muito rápidas, muito bonitas. O espetáculo era engenhoso” ${ }^{217}$. Nina de Pádua também se lembrou: "Minha trajetória: eu entrava por aqui, dava um soco, chutava o outro, rodava. Com outras coisas rolando. Eram trinta pessoas fazendo, cada uma, quinze coisas: parece que são quinhentas pessoas! E ele conseguia fazer isso belamente, ninguém se esbarrava" 218 .

Nina se referiu mais de uma vez a essa habilidade do coreógrafo de fazer com que trinta atores se tornassem trezentas ou quinhentas pessoas representadas em cena. Para a realidade material do teatro brasileiro, poderia parecer um luxo dispor de quase trinta atores no coro (o Sistema Coringa de Boal explicitou o alto custo de manter elencos numerosos e a necessidade de os atores se desdobrarem em cena). Mas mais de uma vez Peixoto afirmou nas fitas que "faltava gente” para caracterizar determinado ambiente - o acampamento militar holandês ou o exército português. Essa preocupação do diretor em retratar os coletivos que compunham a vida social do Recife foi acolhida por Zdenek em seu trabalho com o coro.

A atriz Imara Reis também descreveu a cena da invasão. Lembrou-se do seguinte detalhe: "Eles passavam as mulheres por cima deles. Um pessoal disse: mas a Maria é pesada! Zdenek subiu no palco, combinou algo com a Maria e ficou conversando com a gente, mostrando como é que segurava a pessoa no alto! Ele nos ensinou várias técnicas” ${ }^{219}$. Talvez o gesto dos homens de passar as mulheres por cima deles esteja relacionado com a sugestão dramatúrgica de tratar Anna de Amsterdam como despojo de guerra. Um coro numeroso permitiria que diversas mulheres fossem colocadas na mesma humilhante situação.

Peixoto e Masetti comentaram a cena da invasão em seu diálogo:

\footnotetext{
217 VASCONCELOS, Anselmo. Entrevista sobre Calabar. Entrevistadora: Nina Hotimsky. São Paulo, jul. 2017.

218 PÁDUA, Nina de. Entrevista sobre Calabar. Entrevistadora: Nina Hotimsky. Rio de Janeiro, jan. 2018.

${ }^{219}$ REIS, Imara. Entrevista sobre Calabar. Entrevistadora: Nina Hotimsky. São Paulo, ago. 2016.
} 
Peixoto - A invasão acho que está bem resolvida. Um problema de resolver (talvez com mais detalhes no espaço) certo tipo de movimentação. Acho que passava a ideia da invasão. Talvez nela faltasse um pouco de sangue, de violência.

Masetti - Exatamente. Ela estava mais pro porre do que pra violência.

Peixoto - Mais pro porre do que pra violência.

Masetti - Mais pra comemoração do que pra...

Peixoto - Comemoração de vitória do que pra aportar aqui. Talvez precisasse de mais detalhes violentos e menos do sexo e de porre.

Masetti - Exatamente. Eu achava que a cena tinha que ter uma puta violência para contrapôr com o Hélio Ary (...)

Peixoto - A invasão feita com um cara que está se levantando da privada e correndo de espada e calça na mão! (1973)

Esse trecho indica que a invasão seria representada logo após a cena da latrina, e a violência deveria justamente romper a comicidade escatológica da cena anterior.

Nesse caso, a cena coincidiria com a seguinte rubrica da dramaturgia:

Ao toque de caixa, holandês levanta-se e sai. Entram Dias, Camarão e Souto puxando Anna pelos cabelos. Soldados holandeses depositam armas. Mathias dirige-se ao centro da movimentação. Entram em cena barricas de vinho e outros despojos de guerra. Vivas e morras. Grito estridente de Anna, atirada ao solo por Souto (BUARQUE; GUERRA, 1974, p. 23).

A imagem da guerra viria após sabermos de seus resultados - a rendição de Porto Calvo e a provável execução de Calabar. Outra possibilidade é que estejamos tratando de duas cenas diferentes: uma da batalha em si e outra da comemoração violenta da vitória. De uma maneira ou de outra, alguns aspectos da movimentação do coro ficam explícitos. Tratava-se de uma marcação bela e engenhosa, mas que privilegiava o porre e a sexualidade em detrimento de um retrato da violência, do estrago humano produzido por uma guerra colonial. E isso preocupava o diretor. Em outros aspectos da encenação esse estrago era explicitado, o que aproximava os tempos duros do Brasil colônia e o contexto histórico da década de 1970. Um bom exemplo são os objetos de cena: havia bonecos que representavam corpos mortos em decomposição ${ }^{220}$, armas de fogo ${ }^{221}$ e instrumentos de tortura ${ }^{222}$.

220 Houve a tentativa de reaproveitar esses bonecos no cenário do show Tempo e contratempo, de 1974. Helio Eichbauer, cenógrafo da peça e do show, descreveu: "Tinha alguns bonecos do Calabar, corpos em decomposição feitos por um aderecista que nós usamos na peça” (EICHBAUER apud BORGES, 2017, p. 238). Mas a utilização dos bonecos foi vetada pela censura, pois os mesmos foram considerados subversivos. Ruy Guerra descreveu uma longa discussão com a censora a esse respeito - ele considerava 
Apesar da presença de violência tanto na fábula de Calabar como na realidade da Ditadura Civil-Militar, a forma como Zdenek organizava a criação nutria algo de festivo - uma festa real, e não irônica. Um espaço para bons encontros. Os atores do coro entrevistados falam de um ambiente com grande abertura para a improvisação, e a instauração de um jogo corporal vivo e constante. Era mais um aspecto da sala de ensaio democrática $^{223}$ : Peixoto queria que os atores participassem das discussões sobre o texto, e Zdenek queria que participassem ativamente da criação coreográfica. "Ele não chegava e dizia “faz assim”, não. Ele propunha um jogo”224, descreveu Anselmo.

O método criativo teria algo da liberdade que o tempo histórico negava aos brasileiros. Nas palavras de Nina de Pádua: “Zdenek não fazia marcação. Ele deixava você livre. Eu tinha que ir daqui a ali, dar uma olhada pra cá, tinha que bater num cara ali. Mas eu podia ir no meu movimento, no meu tempo. E ele conseguia coisas extraordinárias com isso!” ${ }^{225}$. Além de elogiar o resultado estético que se obtinha, Nina ligou esse ambiente a um sentido político. "Era uma época barra pesada: amigos desaparecendo, gente que saiu pra comprar cigarro e nunca mais voltou. Aquilo significou para uma geração um grito de liberdade imenso. Um grito de coragem. A gente tinha orgulho de ser do elenco de Calabar"226. Esse grito de coragem e de liberdade tem alguns aspectos. Havia a resistência de ensaiar aquela peça sob a ameaça de censura, em um tempo de amigos desaparecidos e artistas de esquerda exilados. E

importante “ir aos limites” nesses momentos de arbitrária negociação (GUERRA, 2006). Sérgio Cabral afirma que o show Tempo e Contratempo "foi provavelmente o único espetáculo [show] brasileiro a ter um cenário proibido pela censura” (CABRAL apud CHEDIAK, 1999). Isso indica que os corpos em decomposição representados pelos bonecos realmente produziam um impacto, veiculavam a crítica à violência do regime civil-militar.

221 Anselmo Vasconcelos lembrou-se em entrevista de objetos de cena representando bacamartes, o que relacionou com o retrato da crueldade da colonização portuguesa: “A arma dos portugueses, tinha isso no espetáculo. Eles usavam uma arma chamada bacamarte. Bacamarte é a arma mais covarde que você pode imaginar. É uma espécie de um canhão manual, uma espingarda com uma boca desse tamanho assim, que eles enchiam com bolas de chumbo e pólvora e aquilo atirava num raio de dez metros, destruía”. VASCONCELOS, Anselmo. Entrevista sobre Calabar. Entrevistadora: Nina Hotimsky. São Paulo, jul. 2017.

222 A morte de Calabar seria representada com um garrote (ou garrote vil), instrumento de tortura utilizado também para a execução de sentenciados à morte. Como método de execução, foi historicamente mais utilizado em pessoas pobres, camponeses - por isso ele passou a ser chamado "vil". A cena não chegou a ser ensaiada da maneira que a equipe de direção a idealizava: "Inclusive a morte de Calabar a gente nunca fez né? Com o garrote. Nunca foi feito” (1973).

223 Termo usado por Imara Reis em sua entrevista.

224 VASCONCELOS, Anselmo. Entrevista sobre Calabar. Entrevistadora: Nina Hotimsky. São Paulo, jul. 2017.

225 PÁDUA, Nina de. Entrevista sobre Calabar. Entrevistadora: Nina Hotimsky. Rio de Janeiro, jan. 2018.

226 PÁDUA, Nina de. Entrevista sobre Calabar. Entrevistadora: Nina Hotimsky. Rio de Janeiro, jan. 2018. 
havia a experiência de liberdade inerente ao processo criativo - que, não fosse a censura, seria transformada em uma sensação compartilhada com os espectadores ${ }^{227}$.

Não necessariamente Zdenek Hampl se aliava a determinada corrente política. Enquanto Peixoto militava no Partido Comunista, Zdenek é descrito pelo colega José Lavigne como um homem de temperamento anárquico: "prefiro chamar de anárquico do que comunista, assim o que é meu eu divido contigo, nada é de ninguém, não tudo é do Estado, tudo é nosso” (LAVIGNE apud SIQUEIRA, 2009, p. 44). Zdenek chegou a presenciar as contradições do regime comunista na Tchecoslováquia, especialmente após o fim da Primavera de Praga: “Já me era claro que não poderia voltar a 1968 tanques russos pelas ruas, enfim, garantia de um retrocesso político de dez a quinze anos” (HAMPL apud SIQUEIRA, 2009, p. 30). Essa vivência foi determinante para sua escolha de emigrar, e provavelmente determinou suas opções (ou isenções) políticas no Brasil. Em seus textos e entrevistas, não menciona engajamento em qualquer militância organizada.

Há sim, relatos de seu desprendimento em relação ao dinheiro ${ }^{228}$; ele orientava sua vida por parâmetros não hegemônicos. Enquanto muitos artistas de dança vivem sob uma disciplina quase militar, Zdenek afirmava: “Cada um deve escolher sua própria disciplina. Fumo, bebo e continuo dançando. (...) Quanto mais o indivíduo estuda, quanto mais e com maior intensidade vive, mais alicerces terá na hora de criar” (HAMPL apud SIQUEIRA, 2009, p. 71). Ao exercer a função de coreógrafo, função frequentemente caracterizada por uma centralização rígida nas decisões, ele estimulava a criação dos demais artistas e não a imposição de uma forma pré-determinada por ele. Embora Zdenek não tenha sido declaradamente um propagador da contracultura, sua vida e seu método de trabalho sugerem a adesão a algumas das formulações da contracultura.

Pode ser que a condução de Zdenek tenha incentivado a presença de "sexo e porre” (palavras de Peixoto) em cenas que, na expectativa do encenador, deveriam conter violência e exploração do trabalho. O coreógrafo pode ter voltado o trabalho de

\footnotetext{
227 Marcos Napolitano (2010) fala das situações de audição coletiva de canções de protesto como uma "rede de recados" contra a ditadura civil-militar. Também o teatro frequentemente cumpria essa função de cumplicidade, sociabilidade entre os insatisfeitos, vislumbre de que a situação do país poderia ser transformada.

228 "Sua opção por dividir tudo o levou a uma pobreza material no final da vida. Se na Tchecoslováquia ele se habituara à segurança de que não teria fome, no Brasil encontrou uma realidade de "não se ter para onde correr”'” (LAVIGNE apud SIQUEIRA, 2009, p. 44).
} 
expressão corporal para questões ligadas à sexualidade - seja por interesse estético, seja por conexão com as contestações comportamentais praticadas pela juventude à época.

Uma segunda hipótese é que a leitura da dramaturgia feita por Zdenek tenha apontado para esse caminho. As anotações de Peixoto na primeira versão do texto revelam seu olhar materialista dialético, a ênfase que ele dedicava aos aspectos econômicos discutidos em Calabar. As guerras coloniais, a produção e a circulação do açúcar eram temas fundamentais para o encenador. Ao mesmo tempo, o próprio Peixoto considerava a dramaturgia pouco minuciosa quanto a uma análise marxista da realidade. O trabalho em torno do açúcar e as batalhas coloniais eram mencionados pelos personagens no texto, mas não colocados explicitamente em ação. Assim, é possível que Zdenek tenha optado por aprofundar as movimentações de orgia e festa presentes na dramaturgia. Aparentemente, ele se dedicou menos às imagens mortuárias que a mesma dramaturgia oferece.

É possível imaginar um terceiro motivo para a irrupção de cenas de "sexo e porre” em Calabar. É possível que a liberdade criativa incentivada pelo coreógrafo tenha simplesmente aberto espaço para essas movimentações (assim como, segundo Zé Celso, foram os atores de Roda Viva que trouxeram a contestação comportamental para a cena cinco anos antes). Essa hipótese pressupõe que aspectos da contracultura fossem cultivados pelos próprios atores do coro de Calabar $^{229}$. Era uma geração que via no erotismo e na lisergia uma forma possível de dizer não. Ou, no mínimo, era um momento histórico repleto de violência real, no qual representar a violência em cena poderia ser dolorido para os atores. Alguns deles se engajavam na guerrilha que realmente ocorria fora dos palcos. Outros não militavam, mas tiveram conhecidos que foram perseguidos. No momento de improvisar, esses atores preferiam explorar os encontros corporais ligados ao prazer e não à dor.

Masetti descrevia Calabar como uma continuidade do Teatro de Arena ${ }^{230}$. Anselmo admitiu a presença de um fator ideológico semelhante aos musicais do Arena,

\footnotetext{
229 Masetti afirmou sobre a montagem de 1973 que "ela era extremamente libertária. Ela era extremamente livre porque eram atores cariocas jovens, bonitos, vibrantes”. Ele relacionou diretamente um dado estético da montagem com as características dos integrantes do elenco. Nesse ponto da entrevista, defendeu que esse era um dos aspectos que diferenciava a encenação carioca de Calabar de 1973 e a de 1980, realizada em São Paulo.

${ }^{230}$ Quando perguntado sobre em que medida a encenação de Calabar veio dos musicais políticos dos anos 1960 (especialmente os do Arena) e em que medida rompeu, afirmou: "No caso do Fernando não teve rompimento nenhum”. MASETTI, Mário. Entrevista sobre Calabar. Entrevistadora: Nina Hotimsky. São Paulo, nov. 2016.
} 
mas via a peça mais ligada às “dionisíacas plasticidades do Oficina”231 (grupo com o qual Peixoto rompeu por divergências estéticas e ideológicas). O ator afirmou: "Era uma proposta de transgressão em todos os níveis (...). Tinha essa coisa sexualizada. [Aponta uma fotografia de ensaio] ${ }^{232}$. Coxa de fora, pegação. A música que eu acho definidora do espetáculo é essa: Não existe pecado do lado de baixo do Equador”233. Aqui o refrão foi tomado sem ironia, como um elogio mesmo às transgressões comportamentais. O risco dessa interpretação: que se ignorasse a camada crítica que a ironia da canção veicula. Ao menos na dramaturgia, quem começa a cantar a ausência de pecado é a prostituta Anna, que precisa vender seus serviços para os novos clientes holandeses. A coxa de fora seria a sua, e a pegação, uma profissão.

Peixoto incluiu na encenação um povo que se organizava como classe, algo que não existia na dramaturgia. Zdenek partiu de povos que festejavam enquanto exerciam seu poder colonizador ou eram colonizados, sugeridos pela dramaturgia, e encontrou em seu trabalho com o coro uma festa legítima. Como descreveu Anselmo: "havia o texto da peça e havia o texto da corpografia que esse elenco desenvolvia com as noções dadas pelas propostas do Zdenek”234.

Não houve tempo para que tal corpografia da festa fosse retrabalhada pelo encenador. Em alguns pontos, o erotismo e o porre não deixavam espaço para a violência. Por outro lado, o próprio Peixoto avalia no diálogo com Masetti: “eu acho que tinha que esculhambar mais, o espetáculo inteiro estava um pouco bem comportado. Ele estava precisando de um desbunde maior” (1973). Vimos como Peixoto relacionou desbunde e ironia ao analisar a cena final da peça. É provável que a expressão de desbunde trabalhada por Zdenek (sua forma e a escolha de cenas em que se fazia presente) não fosse exatamente a esperada pelo encenador.

Embora os atores do coro se percebessem realizando transgressões comportamentais, o efeito das cenas na plateia poderia não alcançar a intensidade que produziria o seu oposto (característica da ironia como figura de linguagem). Um dos grandes incômodos de Peixoto com o pouco tempo para ensaios, decorrente da forma de

${ }^{231}$ VASCONCELOS, Anselmo. Entrevista sobre Calabar. Entrevistadora: Nina Hotimsky. São Paulo, jul. 2017.

${ }^{232}$ As fotografias de ensaio estão disponíveis como anexo da dissertação; o entrevistado se referia à Figura 12 - Anexo C.

${ }^{233}$ VASCONCELOS, Anselmo. Entrevista sobre Calabar. Entrevistadora: Nina Hotimsky. São Paulo, jul. 2017.

${ }^{234}$ VASCONCELOS, Anselmo. Entrevista sobre Calabar. Entrevistadora: Nina Hotimsky. São Paulo, jul. 2017. 
produção de Calabar, era a impossibilidade de formar atores; de trabalhar com eles a partir dos pressupostos do teatro épico dialético que buscava realizar. Segundo ele, ao lidar com um ator que "ainda acredita numa verdade, numa emoção, numa identificação com o personagem, você dificilmente tem tempo de conseguir trabalhar o cara e explicar pra ele as verdadeiras razões do que você está querendo. Isso deixa o trabalho meio pela metade” (1973).

Essa preocupação não foi expressa somente em relação aos atores do coro, e dizia respeito ao elenco de forma geral. O diretor menciona três atores mais experientes com os quais via de regra não encontrava essa dificuldade, atores que sabiam "realizar o personagem de fora”: Antônio Ganzarolli, Hélio Ari e Flávio São-Tiago. No entanto, vindo de experiências com grupos estáveis como o Oficina e o Arena (e em certa medida também o Grupo Núcleo e a Companhia do Teatro São Pedro ${ }^{235}$ ), o encenador se ressentia de não poder trabalhar com cada um dos atores de maneira mais profunda.

Peixoto esperava que a esculhambação levada ao limite pelos atores poderia operar na plateia o movimento crítico: o que é bom para os Estados Unidos não é bom para o Brasil! Essa certeza revoltante, se compartilhada por artistas e espectadores, poderia "instituir um trabalho em comum entre o palco e a plateia - trabalho cujo objeto é o mundo” (DORT, 2010, p. 327). Essa formulação de Bernard Dort ${ }^{236}$ sintetiza $^{2}$ aspectos da concepção brechtiana de teatro, e certamente encontrava eco no fazer artístico de seu amigo Peixoto. O diretor chegou a escrever algo muito parecido em seu texto para o programa de Calabar: “O que importa é o diálogo palco-plateia. A realidade, a ser transformada, está fora do teatro” (PEIXOTO, 1989c, p. 157).

Dort opõe essa postura à concepção tradicional de teatro, em que o palco ensinaria a verdade à plateia. Para tanto, representação e realidade teriam de coincidir. Talvez a experimentação de transgressões corporais por parte dos atores, embora viesse para questionar o status quo, buscasse um efeito mais parecido com esse da concepção tradicional: um palco que deseja mostrar um caminho melhor e mais livre para os espectadores. Um possível problema era fazê-lo a partir de uma dramaturgia em que o povo perplexo não age $\mathrm{ag}^{237}$.

\footnotetext{
${ }^{235}$ Peixoto afirma que o pouco tempo para trabalhar os atores também aconteceu no espetáculo Frank $V$, realizado com a Companhia do Teatro São Pedro. É fato que as experiências de trabalho coletivo foram menos duradouras ali do que no Teatro Oficina e no Arena.

${ }^{236}$ Peixoto traduziu textos de Dort para o português, inclusive o trecho citado acima - que integra o livro $O$ teatro e sua realidade.

${ }^{237}$ Movimento que aproxima, aliás, o coro de Calabar e o coro da primeira dramaturgia de Chico Buarque, Roda Viva. Também em Roda Viva o coro proposto pelo texto seria manipulado todo o tempo.
} 
Em suma, o espetáculo quase pronto tinha ainda dissonâncias, que refletiam as diferenças dos artistas envolvidos e os impasses de seu tempo histórico. A representação do povo em festa reunia algumas dessas contradições. Havia a triste constatação de um povo que não altera a História, por parte da dramaturgia. Havia a vontade do encenador de que essa festa, lida em chave irônica, aprofundasse a crítica social veiculada pelo espetáculo. E a presentificação da festa pelos atores tocava em propostas da contracultura, no desejo de incluir uma contestação dos costumes operada não no plano da ficção, mas como prática verdadeira.

\section{$\underline{\text { Povo atento }}$}

A ironia não bastava para Peixoto. Ele desejava incluir na obra um vislumbre mais estruturado de transformação da sociedade. E a organização progressiva do povo enquanto classe social, enunciado da encenação que a dramaturgia pouco endossava, precisava se materializar durante toda a peça para se constituir. Uma dificuldade: o segundo ato possuía uma quantidade grande de cenas íntimas, em que o coro estaria ausente. Peixoto queria fazer toda a peça ocorrer com o povo trabalhando e vivendo, mas como incluí-lo durante os diálogos de casais?

As cenas entre Anna e Bárbara e entre Bárbara e Souto se justificavam por variar o tema da traição, central para o texto. Embora se quisesse debater a acusação de traição feita aos guerrilheiros, também a traição amorosa entrava na discussão. Não apenas como analogia de questões políticas proibidas, mas como questão em si ${ }^{238}$. As canções de Chico Buarque (aqui em parceria com Ruy Guerra) frequentemente carregam um erotismo intenso. Peixoto, atento aos gestus das canções ${ }^{239}$, lidava com esse dado.

\footnotetext{
Mas Zé Celso alterou o sentido da coralidade ao aprofundar sua presença e incluir em cena a vivência contracultural do elenco.

${ }^{238} \mathrm{O}$ debate sobre diferentes maneiras de se relacionar amorosamente era então colocado em pauta pela contracultura. Um dos projetos experimentados por seus adeptos era a construção de comunidades não pautadas pelo que consideravam as neuroses da família nuclear burguesa. Questionava-se inclusive a fidelidade enquanto um valor amoroso, e por extensão, a ideia de traição. O psicanalista William Reich analisou experiências de comunas formadas na União Soviética pouco após 1917 - seu livro sobre o tema da revolução sexual foi discutido por Maciel em A nova consciência. Os adeptos do underground acreditavam que seria possível transformar estruturas familiares burguesas mesmo antes de uma reformulação estrutural da sociedade. Maciel discorre sobre o assunto no texto A nova família: "As comunidades não autoritárias, as novas famílias livres das tradicionais compulsões neuróticas, começam a se multiplicar em todo o mundo. (...) Dessas comunidades surgirá, dentro de alguns anos, uma nova geração, criada sobre princípios mais saudáveis, mais livres e imunes às neuroses corrosivas”. (MACIEL, 1973, p. 51).

${ }^{239}$ Vimos como essa preocupação do encenador já aparece nos cadernos de direção de Frank V. O texto Acerca da música-gesto, de Bertolt Brecht, provavelmente foi inspirador para esse aspecto do trabalho de
} 
“Embora a música não tivesse um sentido crítico permanente, muitas músicas tinham esse sentido” (1973), afirmou. Uma montagem que se propôs a incluir o texto na íntegra teve de trabalhar esse erotismo, que muitas vezes carregava um sentido crítico, mas não todo o tempo - e nem sempre incluindo o povo como agente de transformação.

Meneses analisa diversas obras de Chico Buarque a partir do conceito de canções de repressão. Sua análise pode ajudar a relacionar erotismo e politização. Para ela, nas canções de repressão:

a grande constante é a intersecção dos planos pessoal e social, afetivo e histórico, sexual e político. Daí a tentação de uma análise reichiana ser muito grande, pois para Reich a confluência do social com o pessoal se faz no espaço do corpo(...). Assim, não se trata em Chico Buarque de um processo de deslocamento para driblar a censura - em que, por exemplo, ele falaria de "amor reprimido" quando quisesse se referir a uma práxis política reprimida. As suas metáforas são para serem entendidas também na sua literalidade afetiva, e não apenas no seu registro político (MENESES, 1982, p. 81).

A noção de que é no corpo que confluem o plano íntimo e o público leva Meneses a recorrer também a Marcuse - autor que inspirou Peixoto na montagem de Poder Negro. Se para a psicanálise toda civilização depende de algum grau de repressão, Marcuse observa nos regimes totalitários o que ele chama de "mais repressão”. Sua forma histórica extrema seria o fascismo, “destruição de qualquer tipo de auto regulação” (p. 83). O regime civil-militar brasileiro teria traços desse controle adicional, dominação extrema, esmagamento do princípio do prazer, repressão operada nos diversos aspectos do cotidiano. Um exemplo prático era a censura, que era tanto política quanto moral.

Mas como conjugar erotismo e organização do povo? Em Cala a boca Bárbara, localizada no início do primeiro ato, o povo estava presente para mandar Bárbara silenciar, protegendo-a. A construção da personagem dependia de uma constituição potente de seu amor, e Peixoto trabalhava nesse sentido: "era muito bonito se a atriz surgisse nua e fosse se vestindo durante a introdução da música, e então começasse a

Peixoto. Ela seguiu presente nos cadernos de direção de Calabar. No diálogo com Masetti esse é um dado discutido - por exemplo, em Tira as mãos de mim Peixoto afirma que o gestus havia sido encontrado. Ele descreve como os gestos coreográficos (provavelmente trabalhados em parceria com Zdenek) tornaram-se gestus da música: “O Tira as mãos de mim eu achava bacana pra burro. Inclusive como solução coreográfica, a parte do saxofone meio Gershwin, aquele negócio de pegar vários momentos, e vários gestos dos dois atores e fazer deles o gestus da música. E a música era das coisas mais bonitas da peça” (1973). 
cantar. Isso não foi concluído” (1973). A nudez da atriz reforçaria cenicamente um dado da canção: o guerrilheiro conhecia o corpo da amada como conhecia a própria terra, que lutava para libertar. Seus rios, trincheiras, correntes e vazantes ${ }^{240}$. Calabar era íntimo do país como era íntimo de Bárbara, e saberia fazer o melhor para ambos. Com a licença de citar outra canção de Chico Buarque, o corpo de Bárbara era testemunha do bem que Calabar fazia a ela ${ }^{241}$ - e poderia fazer para o país. A mulher passava a alegorizar o Brasil, sem com isso deixar de cantar o próprio prazer.

Aqui a dramaturgia já sobrepunha o amor ao guerrilheiro e o perigo de entoá-lo. Cultivar a memória de Calabar era uma maneira de manter seu projeto de luta vivo ${ }^{242}$. O coro presente impedia a canção de ficar circunscrita à intimidade da personagem. A solução de trabalhar a movimentação de trabalho coletiva do coro fez com que o pedido de silêncio convivesse com a possibilidade de um futuro momento de ação política. A quietude poderia ser rompida pelo povo.

Também em Tatuagem (cantada ainda no primeiro ato) erotismo e politização caminham juntos, pois o desejo da amada é ficar no corpo de um preso político condenado à morte. Nesse momento o coro não se fazia presente. Após o término da canção e durante a leitura da sentença, a atriz Tetê Medina ficava sozinha com Calabar: “o fato de ficar vazio o palco enquanto acontecia aquilo [a leitura da sentença] eu achava bonito. Com a Tetê olhando a figura dele, dava uma espécie de pausa no espetáculo” (1973). Havia um momento de despedida íntima entre Bárbara e seu amado.

A pausa era encerrada sonoramente pelo fundo orquestral de Cobra de Vidro que no segundo ato seria executado com letra, tornando-se canção de luta. Seguia-se a Tatuagem a cena de Bárbara questionando os três heróis, que não agiam para salvar Calabar. O assunto era público, um problema de justiça. A encenação concebeu uma marcação geométrica, um triângulo: enquanto realizava sua ação de interrogar os heróis,

\footnotetext{
${ }^{240}$ Segue a letra completa da canção: Ele sabe dos caminhos dessa minha terra /No meu corpo se escondeu, minhas matas percorreu /Os meus rios, os meus braços/Ele é o meu guerreiro nos colchões de terra/Nas bandeiras, bons lençóis/Nas trincheiras, quantos ais, ai/Cala a boca - olha o fogo!/Cala a boca olha a relva!/Cala a boca, Bárbara/Cala a boca, Bárbara/Ele sabe dos segredos que ninguém ensina/Onde guardo o meu prazer, em que pântanos beber/As vazantes, as correntes/Nos colchões de ferro ele é o meu parceiro/Nas campanhas, nos currais/Nas entranhas, quantos ais, ai/Cala a boca - olha a noite!/Cala a boca - olha o frio!/Cala a boca, Bárbara/Cala a boca, Bárbara

${ }^{241}$ Chico Buarque escreveu em $O$ meu amor: "Meu corpo é testemunha do bem que ele me faz". Essa canção integra a dramaturgia de Ópera do Malandro, de 1978: também foi composta para ser cantada por uma atriz de corpo presente.

${ }^{242}$ Vimos como o nome de Calabar está contido no refrão de Cala a boca Bárbara.

Também em Tatuagem erotismo e politização caminham juntos, pois o desejo da amada é ficar no corpo de um preso político condenado à morte.
} 
a personagem era “o único elemento móvel da cena” (1973) ${ }^{243}$. Bárbara personificava a possibilidade de revolta que mais tarde seria cantada por todo o povo, a partir da mesma melodia que agora a encorajava. Cobra de vidro se constituía como uma espécie de leitmotiv do protesto.

Mas ao longo do segundo ato a ação mais frequente do povo é aclamar seu líder populista Nassau. Não há intervenção coral prevista em Você vai me seguir, Tira as mãos de mim, Anna e Bárbara, Fortaleza. Como fazer a passagem entre a revolta de Bárbara e o protesto coletivo? Peixoto solucionou essa questão incluindo o povo como observador. Com isso, fazia as cenas de casal (o segundo diálogo de Bárbara e Souto e o número amoroso Anna e Bárbara) perderem parte de sua intimidade. A presença desse coletivo também amparava a decisão de ação popular representada pela passeata em Cobra de Vidro. Antes de cantar o verso "Presta atenção", o povo já tinha como ação estar atento:

Eu gostava quando o povo depois do Boi voador ficava estático em cima da ponte. A partir daí, com a luz, a gente ia criar um painel dos caras em cima da ponte. E as cenas mais íntimas que vem depois aconteceriam na frente daquele povo. Então as cenas perderiam um pouco a intimidade que elas têm, e ganhariam uma outra dimensão porque elas seriam lidas pelo espectador através da presença do povo parado na ponte (1973).

O recurso de incluir espectadores internos poderia inscrever as cenas íntimas em seu contexto histórico. Enquanto Souto enlouquece, enquanto Anna seduz Bárbara, o povo do Recife continua ali. Bárbara grita ao mundo que Calabar existiu e não pode ser esquecido; o povo talvez ecoasse a sua memória. Os cacos de sonho e o veneno do herói morto não surgiriam repentinamente em um povo perplexo e sem ação, mas seriam cultivados durante as traições mais íntimas.

A presença do povo na ponte não estava prevista na dramaturgia de Calabar; essa foi uma contribuição da encenação. É possível que Peixoto tenha se inspirado em soluções do já mencionado diretor francês Roger Planchon, também um estudioso do teatro épico brechtiano. Ruy Guerra afirmou em entrevista que a encenação de Calabar

\footnotetext{
243 Segue a descrição completa dessa cena: “Começava a cena que eu achava das mais bonitas do espetáculo, que era a dos três heróis. Eu acho que a marcação geométrica que se encontrou na cena, aquele triângulo, e o fato da cena ser mantida num nível nada realista, como movimentação, ser mantida dentro daquele desenho geométrico da cena, do triângulo, e o fato de deixar como único elemento móvel na cena a Bárbara interrogando acho que dava todo o dinamismo na cena. Além do fato de que os três atores passavam exatamente as ideias. Essa é uma cena que eu achava bastante bem realizada” (1973).
} 
“vai desde o Teatro de Revista até Planchon” (BUARQUE; GUERRA, 1973, p. 2). Na fita que gravou sozinho, Peixoto se coloca como objetivo contribuir para o revisionismo brechtiano no nível de intensidade e de inquietação de Planchon, que "em Tartufo aprofundava cada segundo do espetáculo num nível absolutamente fascinante” (1973c). A aproximação entre a cena da ponte e a estética do diretor francês fica clara nessa descrição de sua montagem de Jorge Dandin, de 1958:

Para tornar visualmente mais claro o gestus do personagem, Planchon não hesita em introduzir no palco figurantes não previstos por Molière, camponeses, testemunhas mudas e acusadoras da ascensão social de Jorge Dandin. Pela sua presença miserável, pelo seu comportamento voltado para o trabalho, eles revelam o preço que é pago por essa ascenção. Mostram também a solidão social de um homem que rejeitou e subjugou a sua classe de origem, sem conseguir fazer-se reconhecer pela classe dominante cujas portas ele tenta forçar. (ROUBINE, 1998, p. 201).

Analogamente, a presença do povo na ponte poderia tornar mais cruel o enlouquecimento de Souto, que continuava a guerrear sem ter claro o porquê ${ }^{244}$. E amparava o sofrimento de Bárbara, saudosa de um homem e de sua luta. A personagem se tornaria menos solitária em seus questionamentos e em sua revolta. Bárbara é paramentada com um tecido vermelho, “mais alegre” do que o amarelo: é a existência do povo do Recife que justifica a alegria de uma cor que é símbolo de luta.

Nenhum dos atores do coro entrevistados falou sobre sua presença estática na ponte. Lembraram com mais facilidade as alegrias e desafios de encenar a invasão, dançar frevo, cantar as difíceis melodias compostas por Chico Buarque. Já o diretor assistente Mário Masetti lembrou-se em entrevista de momentos em que os atores do coro "olhavam a cena, serviam a cena" ${ }^{245}$; o dado seria significativo para futuros espectadores. A presença do povo transformava profundamente as cenas íntimas do segundo ato, e preparava o número Cobra de Vidro. A coerência política da única

\footnotetext{
${ }^{244}$ A segunda cena entre Souto e Bárbara foi concebida em torno do elemento cenográfico de uma cela. Ela não chegou a ficar pronta e ser incorporada nos ensaios. De todo o modo, a equipe de direção a considerava muito importante, e sua existência reforça a aposta da encenação em momentos estilizados, poéticos:

Peixoto - A cela que faltou, era um elemento tão importante pros ensaios...

Masetti - Exatamente, tudo apoiado em cima dela...

Peixoto - Ele entrar com a cela, ela ficar junto à cela...

Masetti - A ideia do cara que não tinha casa, né?

Peixoto - Não tinha casa, carregava o próprio cavalo...

Masetti - Primeira fala da cena... "Casa, que casa?”. (1973).

${ }^{245}$ MASETTI, Mário. Entrevista sobre Calabar. Entrevistadora: Nina Hotimsky. São Paulo, nov. 2016.
} 
canção de protesto da peça dependia de um povo que poderia transformar sua observação e sua perplexidade em ação.

Talvez a representação de um povo atento fosse o que de mais honesto e esperançoso aquele tempo histórico poderia produzir. E talvez nesse povo atento a dramaturgia, a encenação e o trabalho corporal coincidissem. Diferentes tendências dentro de uma esquerda em crise poderiam concordar com essa representação do povo. Para lidar com aquela conjuntura era necessário se articular em coletivo, observar os movimentos do poder instituído, preparar-se. Os dramaturgos compuseram uma canção cujo mote é “presta atenção”. O encenador concluiu que uma representação do povo em luta só se justificaria após o espectador testemunhar o povo observando as injustiças daquele mundo. Mesmo os grupos de esquerda ligados à contracultura poderiam se beneficiar de um olhar aguçado sobre os costumes de sua época. O hábito da transgressão comportamental depende de se conhecer bem as expectativas hegemônicas.

A fábula da peça terminava com o adeus de Nassau. A partida do governador holandês também foi desenhada com a presença do coro: “eu achava muito bonito quando se fechava o povo todo de costas junto ao carro de Nassau. E ficava de frente o Frei, o Agente holandês, os dois soldados holandeses, enfim, continuava a dominação holandesa” (1973). O povo sabia que um governante com algumas qualidades (apesar das contradições) estava partindo; um governante pior o sucederia. Bárbara interrompia a cena como atriz e convidava a plateia à traição. Mais uma vez, a simples presença do povo amparava a interrupção da ficção. Ficaremos aqui assistindo a continuidade da exploração imperialista das riquezas brasileiras? Cantaremos alegremente que o que é bom para a Holanda é bom para o Brasil? Caso a peça houvesse estreado, seria essa a sua provocação. 


\section{Considerações finais}

Após a reunião que encerrou a produção de Calabar, e antes de Peixoto e Masetti gravarem suas reflexões sobre a encenação, houve uma festa na casa de Chico Buarque. Ela foi lembrada com afeto pelos integrantes da montagem entrevistados. Peixoto descreveu essa “festa”: “A gente ouve a fita do disco, canta junto. Estamos abatidos, mas não derrotados. Sinto no rosto de todos” (PEIXOTO, 1989b, p. 193).

Masetti concordou que não havia tristeza: “Tinha a sensação de dever cumprido e de alguma coisa que foi cortada, mas estávamos alegres, felizes, bebendo e falando: a luta continua, vamos em frente. Estamos iniciando nossas carreiras de uma maneira bacana, já temos uma história pra contar”246. Nina de Pádua lembrou da proibição de narrar publicamente essa história. "No dia seguinte não podia aparecer a palavra “Calabar”. Isso colaborou pra que ficasse um vínculo. Ficou um pacto de "a gente sabe o que a gente viveu", 247 .

Imara comentou essa união entre dor e festa como uma característica dos cariocas. Mas lembrou-se bem do "repé", da ressaca após a festa - constituída pela ausência de um lugar de respiro que era a sala de ensaios democrática. Ao respiro se seguiram longos períodos de asfixia. Anselmo disse de uma sensação parecida, ao ser perguntado sobre a interrupção causada pela censura. Falou de uma grande dificuldade em "não ter mais os encontros com aquelas pessoas tão significativas. Eu estava apaixonado” ${ }^{248}$. A criação artística e a vivência erótica caminhavam juntas. Setores da sociedade civil em defesa da tradição, da família e da propriedade conviviam com uma juventude transgressora, mas circunscrita a círculos bastante restritos. A ideia de povo brasileiro estava em disputa, mas uma visão conservadora estava vencendo.

Bastava censurar uma peça para cortar certos encontros. A convivência democrática, a troca de ideias, o trabalho corporal cheio de descobertas, a potência das vozes em coro não constituíam um projeto em si. Nesse sentido os ideais da contracultura não se realizavam plenamente. A contestação através dos modos de viver feita por aquele grupo de artistas se dava em função de um trabalho específico. Ela não

\footnotetext{
${ }^{246}$ MASETTI, Mário. Entrevista sobre Calabar. Entrevistadora: Nina Hotimsky. São Paulo, nov. 2016. ${ }^{247}$ PÁDUA, Nina de. Entrevista sobre Calabar. Entrevistadora: Nina Hotimsky. Rio de Janeiro, jan. 2018.

${ }^{248}$ VASCONCELOS, Anselmo. Entrevista sobre Calabar. Entrevistadora: Nina Hotimsky. São Paulo, jul. 2017.
} 
possuía autonomia. A experiência durava enquanto duravam os ensaios, e no caso de Calabar não pode se estender nem mesmo para uma temporada pública da peça.

As memórias da interrupção dos ensaios como um corte afetivo convivem com a lembrança dos prejuízos materiais. Os entrevistados falaram do desemprego coletivo e da expectativa frustrada de um emprego que ainda os sustentaria por um ano inteiro. Também lembraram as perdas do produtor Fernando Torres, a revolta em ver os grandes investimentos nos figurinos serem desperdiçados, o absurdo de ter de devolver o dinheiro dos ingressos já comprados. Não era permitido ao teatro brasileiro se consolidar como atividade econômica viável.

Sobre o espetáculo coexistem lembranças de sua força e incômodos a respeito de seu inacabamento. Dori gostaria que o coro estivesse cantando melhor; Masetti percebia que o segundo ato estava menos trabalhado do que o primeiro, faltava-lhe ritmo e alegria. Na conversa com Masetti, Peixoto comenta que o que mais sentiu foi não ter finalizado o trabalho que desejava com o povo (1973).

O encenador se referia (ao menos no plano da consciência) ao trabalho com o coro de atores. Vimos que suas tentativas de criar em cena um povo revolucionário encontrava pouco amparo na dramaturgia de Calabar. Mas o problema era mais grave: seu ideal para o povo (compartilhado por parceiros do PCB e por outros companheiros) também não encontrava eco na realidade social brasileira. A modernização conservadora mantinha e aprofundava as desigualdades econômicas; a luta social não se refazia com a velocidade sonhada pelos grupos de esquerda. A cobra de vidro ainda jazia em pedaços.

Na fita que gravou sozinho, Peixoto perguntou-se sobre o sentido da própria atividade teatral. Expressou “a necessidade de um estudo maior do próprio significado do teatro enquanto obra de arte, enquanto resultado diante de um público, enquanto reflexão sobre o significado do homem e da História” (1973c). Inacabamentos na encenação censurada conviviam com o inacabamento de um projeto consequente para o Brasil e para o teatro brasileiro.

A dramaturgia produziu uma reflexão histórica. Ela partia do pressuposto de um povo perplexo, um herói morto e a impossibilidade de um governo menos curvado aos interesses econômicos estrangeiros. Mas essa leitura grave da realidade social foi impedida de estrear: a atriz não teve a chance de falar diretamente à plateia. A tentativa de realização de um grande espetáculo crítico (politicamente engajado e com condições 
comerciais favoráveis) falhara. E o ideal de um teatro público, da arte como um direito social, não estava nos planos do Estado brasileiro. Experiências recentes da França e da Itália inspiravam Peixoto ${ }^{249}$, mas não havia perspectivas de implementar algo semelhante no Brasil.

Alguns artistas teatrais se aventuravam pela periferia e abraçavam o amadorismo, aliando teatro e militância ${ }^{250}$. Outros adentravam o mercado da televisão, acreditando que sua crítica poderia ter maior alcance ao ser veiculada pela indústria cultural. As tentativas de criar um teatro experimental ou de contracultura, que operasse às margens do circuito comercial, constituíram uma terceira vertente do início da década de 1970. Os três projetos encontraram suas potências e contradições.

Mas Peixoto fez a opção por seguir no teatro profissional. A crise econômica estava dada, a censura não dava trégua, mas os espetáculos de protesto ainda encontravam algum interesse por parte do público. Sua precariedade era tão constante quanto sua insistência em existir. O que foi impedido em Calabar foi a existência de um espetáculo crítico de grandes proporções. Os mil e trezentos lugares do teatro João Caetano não seriam ocupados por espectadores de um teatro nacional e popular, realista e crítico. Esse projeto teria de seguir confinado em pequenas salas, com pequenos elencos e pequenos orçamentos. Nessas condições, qual seria o seu impacto social?

Em sua carta de despedida a Peixoto, escrita em 1960, Ruggero Jacobbi afirmou: “Só a aproximação entre o teatro e o povo poderá criar um grande teatro e fazer deste teatro um tribunal, um altar, um porta-voz de nossa esperança de vida, de nossa exigência de paz”. Eram grandes as expectativas para o teatro brasileiro. A carta terminava com um imperativo: “e trabalhem”. Peixoto escreveu após a morte do professor: “Até sempre, Ruggero. Estamos trabalhando” (PEIXOTO, 1989b, p. 242). Certamente preferiria estar trabalhando em condições mais favoráveis para a

\footnotetext{
${ }^{249}$ Sara Mello Neiva (2016) contextualiza as iniciativas feitas na Itália e na França para tornar o teatro um "serviço público": "Quando o Piccolo foi inaugurado, em 1947, Jacobbi já estava no Brasil. De todo modo, foi o início de um projeto nacional popular público posto em ação na Itália, que exigia como ideal a subvenção estatal para a manutenção de teatros estáveis e populares com elencos fixos e que se apresentassem a baixos custos para a população. O teatro artístico, em contraposição às produções convencionais, era pensado como serviço público, como um bem necessário para a humanidade, assim como são a água e o direito à moradia. Nesse sentido, a ideia de descentralização dos teatros e de "Teatro de Arte para Todos” estavam na essência do projeto (o slogan do Piccolo era: “Teatro d'Arte per Tutti”). Curiosamente, no mesmo momento histórico, Jean Vilar desenvolve na França seu grande projeto de popularização e democratização da cultura. Tanto na França como na Itália a ideia - e o termo - do teatro como "serviço público" foi empregada com obstinação" (p. 47).

${ }^{250}$ Silvana García (1987) discorreu sobre essas experiências em sua dissertação de mestrado.
} 
constituição desse tribunal, altar e porta-voz. A desejada aproximação do teatro com o povo não estava em um bom momento.

O povo brasileiro de 1973 não assistiu Calabar ${ }^{251}$. Poderia se discutir se o povo teria acesso ao espetáculo caso ele houvesse estreado. Essa era uma das preocupações dos artistas e intelectuais da época, mas junto a ela caminhava o imperativo de seguir com o próprio ofício e fonte de sustento. Em um ciclo de debates sobre o teatro realizado em 1975, Fernando Torres (produtor de Calabar) foi provocado por um membro da plateia com a afirmação de que a classe que vai ao teatro não representa o povo brasileiro. Torres respondeu: “O público que vai lá, que fala a minha língua, que tem os problemas que eu tenho em casa, é a minha classe, é o povo brasileiro”. A resposta foi simplificadora. Ao mesmo tempo, o produtor mencionou suas iniciativas por reabrir teatros nas periferias do Rio de Janeiro e por realizar temporadas populares subvencionadas em teatros grandes (ele cita justamente o Teatro João Caetano, onde ocorreria Calabar), para absorver o maior número de pessoas. Ao ser perguntado sobre o que fazer, Fernando Torres respondeu: "Continuar trabalhando, só isso" (MICHÁLSKY; PONTES; TORRES, 1976, p. 69).

A lembrança da festa ao término da produção de Calabar conjuga alguns fatores significativos. Por um lado, a festa era uma afirmação de vida. A peça não pôde ser compartilhada com o público, não foi um pretexto para encontros dos descontentes com a ordem vigente, não alterou o cotidiano da cidade, não dialogou com milhares de espectadores. Mas o processo de ensaios produziu efeitos sobre os artistas comprometidos com a criação. Havia troca, pensamento e aprendizados acumulados na experiência daqueles oitenta trabalhadores envolvidos com a montagem.

Por outro lado, a festa era uma expressão de solidão e de luto. Tratava-se de uma festa de despedida. Ela encerrava aquele processo de trabalho, e não havia perspectivas certas de continuidade ${ }^{252}$. Na década anterior, Peixoto vivenciou espaços coletivos de fazer teatral, que compartilhavam projetos de médio a longo prazo. Houve a experiência do CPC, que conjugava fazer artístico e militância política. Houve o trabalho com o

\footnotetext{
${ }^{251}$ O Calabar que efetivamente estreou em 1980 lidou com uma conjuntura histórica bastante diferente, já no período da abertura política, e também com outras circunstâncias produtivas. As questões em torno dessa montagem são outras, e não caberão nos limites dessa dissertação.

${ }^{252}$ Alguns artistas que passaram pelo processo de ensaios de Calabar seguiram trabalhando juntos. Vimos que já no ano seguinte, 1974, ocorreram a peça A torre em concurso e o show Tempo e Contratempo, ambos reunindo artistas já envolvidos com Calabar. Embora importantes por consolidar parcerias artísticas, esses empreendimentos não davam seguimento a um projeto claro e continuado para o teatro ou a música no Brasil.
} 
Arena e o Oficina, grupos que por anos estudaram juntos e alimentaram objetivos em comum. A criação estava em função do projeto de um teatro brasileiro que discutisse em cena nossa realidade social. Desde o AI-5, e especialmente no início da década de 1970, tornou-se muito mais difícil a manutenção de companhias teatrais estáveis. A busca pelo aprofundamento de linguagem desejada por Peixoto encontrava obstáculos materiais.

A solidão não era apenas pela falta de grupos teatrais de pesquisa e engajamento. A solidão também era expressão de uma situação de classe. A festa reunia um pequeno coletivo de artistas, em sua maioria integrantes da classe média intelectualizada. Aquele grupo apaixonante enchia um apartamento de cobertura na Lagoa. O Regime CivilMilitar foi um período que afastou os artistas e intelectuais dos demais trabalhadores, de um proletariado, do povo brasileiro que se desejava retratar em cena. Faltou trabalhar com o povo em cena e na vida.

Masetti lembrou-se de uma cena singular da festa: um dos integrantes da produção “bebeu, e ficava andando de gatinhas. Até num lugar perigoso, no último andar. No terraço" 253 . A lembrança risível ecoa o ambiente mortuário de Calabar. O homem não caiu, mas o risco perturbava a expressão de vida à sua volta. Os artistas de esquerda engatinhavam na beira de um precipício. Viam o tamanho do abismo, e tentavam continuar em movimento.

${ }^{253}$ MASETTI, Mário. Entrevista sobre Calabar. Entrevistadora: Nina Hotimsky. São Paulo, nov. 2016. 


\section{REFERÊNCIAS}

ARRABAL, José, LIMA, Mariângela Alves de e PACHECO, Tânia. Anos 70 - Teatro. Rio de Janeiro: Europa, 1979.

AUTRAN, Margarida. O Estado e o músico popular: de marginal a instrumento. In Anos 70 - Música Popular. Rio de Janeiro: Europa, 1979.

BALBI, Marilia. Fernando Peixoto: em cena aberta. São Paulo: Imprensa Oficial do Estado de São Paulo, 2009.

BATISTA, Natália. Nos palcos da história: teatro, política e Liberdade Liberdade. São Paulo: Letra e voz, 2017.

BOAL, Augusto. Que pensa você da arte de esquerda? In: I Feira Paulista de Opinião. São Paulo: Expressão Popular, 2016.

BOAL, Augusto. Teatro do Oprimido e outras poéticas políticas. Rio de Janeiro: Civilização Brasileira, 1977.

BOAL, Augusto e GUARNIERI, Gianfrancesco. Arena conta Tiradentes. São Paulo: Sagarana, 1967.

BORGES, Vavy Pacheco. Ruy Guerra - paixão escancarada. São Paulo: Boitempo, 2017.

BRECHT, Bertolt. Estudos sobre teatro. Rio de Janeiro: Nova Fronteira, 2005.

BRECHT, Bertolt. Teatro completo. Rio de Janeiro: Paz e Terra, 1991.

BUARQUE, Chico. O gênio nasce. Poramdubas - revista do TUCA. 11 set. 1980. Disponível em: <http://www.chicobuarque.com.br/texto/entrevistas/entre_genio.htm>. Acesso em: ago. 2019.

BUARQUE, Chico. [Entrevista para O Globo]. O Globo. 17 jul. 1979. Disponível em: < http://www.chicobuarque.com.br/texto/entrevistas/entre_17_07_79.htm>. Acesso em: ago. 2019.

BUARQUE, Chico. Roda Viva. São Paulo: USP, 1967. (Arquivo Miroel Silveira da Biblioteca da ECA/USP).

BUARQUE, Chico; GUERRA, Ruy. Cala a Boca Barbara (Chico Buarque e Ruy Guerra falam de Calabar). PUC / RJ DCE, 1973a. Disponível em: <http://www.jobim.org/chico/handle/2010.2/2364>. Acesso em: 18 mai. 2018. 
BUARQUE, Chico e GUERRA, Ruy. Calabar. $4^{\text {a }}$ ed. Rio de Janeiro: Civilização Brasileira, 1974.

BUARQUE, Chico e GUERRA, Ruy. Calabar. 13ª ed. Rio de Janeiro: Civilização Brasileira, 1980.

BUARQUE, Chico; GUERRA, Ruy. Calabar. 1973b. Primeira versão da dramaturgia. Texto mimeografado disponível no Arquivo Fernando Peixoto do Centro de Documentação e Pesquisa da Funarte, com anotações de Fernando Peixoto nas margens. BUARQUE, Chico; GUERRA, Ruy. Calabar. 1973c. Segunda versão da dramaturgia. Texto mimeografado disponível no Arquivo Fernando Peixoto do Centro de Documentação e Pesquisa da Funarte, com anotações de Fernando Peixoto nas margens. CALABAR interdit - tradução do texto publicado em “Travail Théâtral”. Travail Théâtral, Paris, $1974 . \quad$ Disponível em: <http://chicobuarque.com.br/critica/crit_calabar_travail.htm>. Acesso em: mar. 2019.

CALABAR Revisado. Revista Veja, São Paulo, p. 84, 25 jul. 1973.

CANDIDO, Antonio. Radicalismos. Estudos Avançados, São Paulo, v. 4, n. 8, p. 4-18, jan./abr. 1990.

CENTRO Popular de Cultura (CPC). In: ENCICLOPÉDIA Itaú Cultural de Arte e Cultura Brasileiras. São Paulo: Itaú Cultural, 2019. Disponível em: <http://enciclopedia.itaucultural.org.br/grupo399389/centro-popular-de-cultura-cpc>. Acesso em: 26 de Jun. 2019. Verbete da Enciclopédia. ISBN: 978-85-7979-060-7 CONVERSOR de valores. Disponível em: < http://acervo.estadao.com.br/> Acesso em: dez. 2017.

CORRÊA, José Celso Martinez. O tempo rodou num instante. Entrevistadora: Nina Hotimsky. Traulito \#5. São Paulo, 2012.

DORT, Bernard. O teatro e sua realidade. São Paulo: Perspectiva, 2010.

HOLANDA, Sérgio Buarque de. Cobra de Vidro. São Paulo: Livraria Martins Editora, 1944.

HOMEM, Wagner. Histórias de canções: Chico Buarque. São Paulo: Leya, 2009.

FERREIRA, Jorge e REIS, Daniel Aarão (org). Revolução e Democracia (1964...). Rio de Janeiro: Civilização Brasileira, 2007.

FONSECA, Rodrigo. Marco da censura no Brasil, Calabar faz 40 anos com nova montagem. O Globo, Rio de Janeiro, 12 mai. 2013. Disponível em: 
$<\underline{\text { https://oglobo.globo.com/cultura/marco-da-censura-no-brasil-calabar-faz-40-anos- }}$ com-nova-montagem-8363246\#ixzz5APDj6egs> Acesso em: abr. 2019.

GARCIA, Miliandre. A luta agora é na Justiça: o processo censório de Calabar. Dossiers - La dictadura em Brasil, nuevos abordajes. PolHis: Ano 5, nº 9, p. 267 282, 2012.

GARCÍA, Silvana. O Teatro Independente - A Intenção do Popular no Engajamento Político. Tese (Mestrado em Artes Cênicas) - ECA, USP. São Paulo, 1987.

GARCIA, Walter. Apontamentos sobre uma canção para teatro: "Funeral de um lavrador”. Literatura E Sociedade, v. 16, n. 15, p.160-173, 2011.

GARCIA, Walter (org). João Gilberto. São Paulo: Cosac Naify, 2012.

GUERRA, Ruy. [Palestra]. 01 nov. 2017. 1 DVD. Palestra realizada na Cinemateca de São Paulo, como parte do Seminário “Arte e Revolução”. Transcrição nossa.

GUINSBURG, Jacó; FARIA, João Roberto; LIMA, Mariângela Alves de. Dicionário do teatro brasileiro: temas, formas e conceitos. São Paulo: Perspectiva: Edições SESC SP, 2009.

HADDAD, Amir. Construção, comunidade, comunicação [Entrevista concedida ao crítico Yan Michalski]. Jornal do Brasil, Rio de Janeiro, 22 jun. 1969.

HAMPL, Zdenek. Memória em dança - entrevista com Zdenek. Recife: 2004. Disponível em: < <https://vimeo.com/25094295>. Acesso em: ago. 2018.

HERMETO, Miriam. Olha a Gota que falta: um evento no campo artístico-intelectual brasileiro (1975-1980). Tese (doutorado) - UFMG / FAFICH / DH / Programa de Pósgraduação em História, 2010.

HOTIMSKY, Nina. (2019). Aspectos da escrita cênica de "Roda Viva”. Revista Aspas, 8(2), 122-141. Disponível em: <https://www.revistas.usp.br/aspas/article/view/150266> Acesso em: mai. 2019.

HOTIMSKY, Nina. Zumbi e Tiradentes, Calabar. Sala Preta, 18(2), 2018, p. 84-94.

MACIEL, Luiz Carlos. Nova consciência: jornalismo contracultural. Rio de Janeiro, Eldorado, 1973.

MAGALDI, Sábato. Hoje, no Teatro São Pedro, os discursos subversivos de Frei Caneca. O Estado de São Paulo. São Paulo, 12 set. 1972.

MAMMİ, Lorenzo. João Gilberto e o projeto utópico da bossa nova. Novos estudos n. 34. São Paulo, Cebrap, nov. 1992, p. 63-70. 
MANOLO. Mário Pedrosa político (4): do golpe militar ao exílio (1964-1970). Passa palavra. Nov. 2009. Disponível em: <https://passapalavra.info/2009/11/14529/>. Acesso em: ago. 2019.

MARTINS, Christian Alves. Diálogos entre passado e presente: "Calabar, o elogio da traição" (1973) de Chico Buarque e Ruy Guerra. Dissertação (Mestrado em História) Programa de Pós-Graduação em História, Universidade Federal de Uberlândia, Uberlândia, 2007.

MARTINS, Christian Alves. Rupturas e permanências: A recepção de "Calabar - o elogio da traição", de Chico Buarque e Ruy Guerra. Tese (Doutorado em História) Programa de Pós-Graduação em História, Universidade Federal de Uberlândia, Uberlândia, 2013.

MATOS, Olgária. Paris 1968 - as barricadas do desejo. São Paulo: Brasiliense, 1981.

MAYRINK, Geraldo. Canções da colônia. Revista Veja, caderno de Literatura, 21 de novembro de 1973.

MENESES, Adélia Bezerra de. Desenho mágico: poesia e política em Chico Buarque. São Paulo: Hucitec, 1982.

MENESES, Adélia Bezerra de. Figuras do feminino na canção de Chico Buarque. São Paulo: Ateliê, 2001.

MICHALSKI, Yan. Como surgiu o novo Calabar. Jornal do Brasil, Rio de Janeiro, Caderno B, p. 20, 18 mai. 1980.

MICHALSKI, Yan. O palco amordaçado. Rio de Janeiro: Avenir Editora, 1979.

MICHÁLSKY, Yan; PONTES, Paulo; TORRES, Fernando. Teatro - 14 de abril de 1975. In I Ciclo de debates do Teatro Casa Grande. Rio de Janeiro: Inúbia, 1976.

MIDANI, André. Música, ídolos e poder - do vinil ao download. Rio de Janeiro: Nova Fronteira, 2008.

MOSTAÇO, Edélcio. Fernando Peixoto, encenador brechtiano. Blumenau: s.n., 2014. Disponível em: <https://primeiroteatro.blogspot.com/2015/08/a-trajetoria-de-umencenador.html?m=1>. Acesso em: jun. 2019.

NAPOLITANO, Marcos. A música popular brasileira (MPB) dos anos 70: resistência política e consumo cultural. Actas del V Congresso Latinoamericano IASPM, 2002. Disponível em:

<http://www.educadores.diaadia.pr.gov.br/arquivos/File/fevereiro2012/historia_artigos/ 2napolitano70_artigo.pdf>. Acesso em: 2 abr. 2018. 
NAPOLITANO, Marcos. MPB: a trilha sonora da abertura política (1975/1982). Estudos Avançados, 2010, 24(69), 389-402. Disponível em: <http://www.revistas.usp.br/eav/article/view/10532>. Consultado em: jun. 2019.

NEIVA, Sara Mello. O teatro paulista do estudante nas origens do nacional popular. (Mestrado em Artes Cênicas) - Programa de Pós-Graduação em Artes Cênicas, Universidade de São Paulo, São Paulo, 2016.

PAIVA, Salvyano Cavalcanti de. Viva o Rebolado: vida e morte do teatro de revista brasileiro. Rio de Janeiro: Nova Fronteira, 1991.

PEDROSA, Mário. A opção brasileira. Rio de Janeiro: Civilização Brasileira, 1966. PEIXOTO, Fernando. Brecht - uma introdução ao teatro dialético. São Paulo: Paz e Terra, 1981.

PEIXOTO, Fernando. Calabar - Caderno 1. 1973a. Caderno de direção manuscrito disponível no Arquivo Fernando Peixoto do Centro de Documentação e Pesquisa da Funarte.

PEIXOTO, Fernando. Calabar - Caderno 2. 1973b. Caderno de direção manuscrito disponível no Arquivo Fernando Peixoto do Centro de Documentação e Pesquisa da Funarte.

PEIXOTO, Fernando. Calabar de 1973. Entrevistadora: Rosângela Patriota. Mai. 2001. Disponível no Arquivo Fernando Peixoto do Centro de Documentação e Pesquisa da Funarte.

PEIXOTO, Fernando. “Duas vezes Calabar”. In BUARQUE, Chico e GUERRA, Ruy. Calabar. 13ª ed. Rio de Janeiro: Civilização Brasileira, 1980.

PEIXOTO, Fernando. CPC: o teatro a serviço da Revolução. In: PEIXOTO, Fernando (org). O melhor teatro do CPC da UNE. São Paulo: Global, 1989a.

PEIXOTO, Fernando. Ruggero Jacobbi, aqui, hoje. Vintém - ensaios para um teatro dialético, n. 1. São Paulo: Hucitec, 1998.

PEIXOTO, Fernando. Teatro em aberto. São Paulo: Hucitec, 2002.

PEIXOTO, Fernando. Teatro em movimento. São Paulo: Hucitec, $1989 \mathrm{~b}$.

PEIXOTO, Fernando. Teatro em pedaços. São Paulo: Hucitec, 1989c.

PEIXOTO, Fernando. Teatro em questão. São Paulo: Hucitec, 1989d.

PEIXOTO, Fernando. Teatro Oficina (1958-1982): trajetória de uma rebeldia cultural. São Paulo: Brasiliense, 1982. 
PEIXOTO, Fernando. [Depoimento sobre Calabar]. Rio de Janeiro: 18 nov. 1973c. 1 fita cassete. Disponível no Arquivo Fernando Peixoto do Centro de Documentação e Pesquisa da Funarte.

PEIXOTO, Fernando; MASETTI, Mário. [Conversa sobre o espetáculo]. Rio de Janeiro: 14 nov. 1973. 1 fita cassete. Disponível no Arquivo Fernando Peixoto do Centro de Documentação e Pesquisa da Funarte.

PRADO, Décio de Almeida. O Teatro Brasileiro Moderno. São Paulo: Perspectiva, 2009.

RIDENTI, Marcelo. Em busca do povo brasileiro: artistas da revolução, do CPC à era da TV. São Paulo: Record, 2000.

RIDENTI, Marcelo. “Esquerdas revolucionárias armadas nos anos 1960-1970”. In FERREIRA, Jorge; REIS, Daniel Aarão. Revolução e democracia - 1964... São Paulo: Civilização Brasileira, 2007.

ROCHA, Elizabete Santos. O elogio da liberdade - Procedimentos estéticos em Calabar. Franca: UNESP-FHDSS, 2006.

ROSENFELD, Anatol. O mito e o herói no moderno teatro brasileiro. São Paulo: Perspectiva, 1996.

ROSENFELD, Anatol. O teatro épico. São Paulo: Perspectiva, 1965.

ROTTERDAM, Erasmo. Elogio da Loucura. São Paulo: L\&PM, 2013.

ROUBINE, Jean-Jacques. A linguagem da encenação teatral. Rio de Janeiro: Jorge Zahar, 1998.

SANTOS, Luciany Aparecida Alves. O marco: uma metodologia de análise. Boitatá Revista do GT de Literatura Oral e Popular da ANPOLL, 2011, n.11, p. 1-15. Disponível em: <http://www.uel.br/revistas/boitata/volume-11-2011/B1101.pdf>. Acesso em: jul. 2019.SIQUEIRA, Arnaldo (org). Zdenek Hampl - Perfis de um artista inovador. Recife: Ed. Do Organizador, 2009.

SCHWARZ, Roberto. Cultura e política, 1964-69”. In O pai de família e outros estudos. Rio de Janeiro: Paz e Terra, 1978.

SZONDI, Peter. Teoria do drama moderno [1880 - 1950]. São Paulo: Cosac \& Naify, 2001.

TOLEDO, Paulo Vinicius Bio. Debates sobre teatro e sociedade após o golpe de 1964: reflexão e trabalho teatral de José Celso Martinez Corrêa e Augusto Boal. Tese (Doutorado em Teoria e Prática do Teatro) - ECA, USP. São Paulo, 2018. 
TOLEDO, Paulo Vinicius Bio. Impasses de um teatro periférico: As reflexões de Oduvaldo Vianna Filho sobre o teatro no Brasil entre 1958 e 1974. Dissertação (Mestrado em Teoria e Prática do Teatro) - ECA, USP. São Paulo, 2013.

VENEZIANO, Neyde. O teatro de revista no Brasil - dramaturgia e convenções. São Paulo: Pontes, 1991.

WEKWERTH, Manfred. Diálogos sobre a encenação - um manual de direção teatral. São Paulo: Hucitec, 1986.

WILLIAMS, Raymond. Drama em cena. São Paulo: Cosac Naify, 2010.

WILLIAMS, Raymond. Palavras-chave. São Paulo: Boitempo, 2007.

\section{Programas de espetáculos}

A Semana, Studio São Pedro, 1972.

Calabar, Teatro São Pedro, 1980.

Frank V, Teatro São Pedro, 1973.

Frei Caneca, Teatro São Pedro, 1972.

Tambores na noite, Studio São Pedro, 1972. 


\section{Entrevistas Realizadas}

CAYMMI, Dori. Entrevista sobre Calabar. Entrevistadora: Nina Hotimsky. Rio de Janeiro, jan. 2018.

CHAVES, Carlos Alberto Teixeira. Entrevista sobre Calabar. Entrevistadora: Nina Hotimsky. São Paulo, ago. 2017.

GUERRA, Ruy. Entrevista sobre Calabar. Entrevistadora: Nina Hotimsky. São Paulo, mar. 2018.

JÚNIOR, Herbert Richers. Entrevista sobre Calabar. Entrevistadora: Nina Hotimsky. São Paulo, jan. 2019.

LAFORET, Renato. Entrevista sobre Calabar. Entrevistadora: Nina Hotimsky. São Paulo, ago. 2016.

MAMBERTI, Sérgio. Entrevista sobre Calabar de 1980. Entrevistadora: Nina Hotimsky. São Paulo, jan. 2019.

MASETTI, Mário. Entrevista sobre Calabar. Entrevistadora: Nina Hotimsky. São Paulo, nov. 2016.

PÁDUA, Nina de. Entrevista sobre Calabar. Entrevistadora: Nina Hotimsky. Rio de Janeiro, jan. 2018.

REIS, Imara. Entrevista sobre Calabar. Entrevistadora: Nina Hotimsky. São Paulo, ago. 2016.

VASCONCELOS, Anselmo. Entrevista sobre Calabar. Entrevistadora: Nina Hotimsky. São Paulo, jul. 2017.

VINICIUS, Marcus. Entrevista sobre Calabar de 1980. Entrevistadora: Nina Hotimsky. São Paulo, jan. 2019. 


\section{ANEXOS}

ANEXO A - Ficha Técnica da montagem de Calabar de 1973.

ANEXO B - Ficha Técnica da montagem de Calabar de 1980.

ANEXO C - Iconografia do processo de encenação de Calabar (1973)

ANEXO D - Desenhos de Hélio Eichbauer para a encenação de Frei Caneca (1972 direção de Fernando Peixoto).

ANEXO E - Diálogo entre Fernando Peixoto e Mário Masetti - 14 de novembro de 1973. (Transcrição de fita cassete localizada no Arquivo Fernando Peixoto - CEDOC Funarte).

ANEXO F - Depoimento de Fernando Peixoto sobre Calabar - 18 de novembro de 1973. (Transcrição de fita cassete localizada no Arquivo Fernando Peixoto - CEDOC Funarte).

ANEXO G - Entrevista com Mário Masetti - 29 de novembro de 2016. 


\section{ANEXO A - Ficha Técnica da montagem de Calabar de 1973}

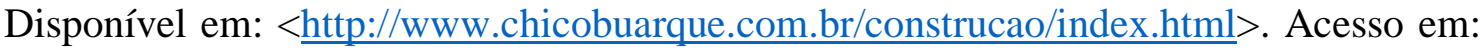
ago. 2019.

Produção: Fernando Torres e Fernanda Montenegro

Direção: Fernando Peixoto

Diretores assistentes: Mário Masetti e Zdenek Hampl

Direção de produção: Cacá Teixeira

Assistente de produção: Renato Laforet e Leda Borges

Direção musical: Dori Caymmi

Orquestração: Edu Lobo

Coreografia: Zdenek Hampl

Cenários: Hélio Eichbauer

Figurinos: Rosa Magalhães e Hélio Eichbauer

Elenco: Tete Medina, Betty Faria, Hélio Ari, Antônio Ganzarolli, Lutero Luís, Flávio São-Tiago, Perfeito Fortuna, Deoclides Gouvêa, Odilon Wagner e mais: Ana Maria Vianna, Ângelo de Mareus, Antonio Pompeu, Anselmo di Vasconcelos, Belara Gudi, Carlos Alberto Santana, Dirce Morais, Dulcilene Morais, Imara dos Reis Ferreira, Ivens Godinho, José Roberto Mendes, Katia D'Ângelo, Lincoln dos Santos, Márcio Augusto, Maria Alves, Maria do Carmo, Nilton Brandão, Nina Pádua, Octávio César, Paschoal Villaboim, Paulo Afonso Gregório, Paulo de Tarso, Paulo Terra, Suzanne Motta Jacob, Taíse Costa, Thelmo Marques, Vilian, Wladimir Gonçalves.

Músicos: Danilo Caymmi, Dori Caymmi, João Palma, Maurício Mendonça, Tenório Jr. Equipe Técnica:

Iluminação: Antonio Pedro

Sonoplastia: M. S. 2001

Divulgação: Leda Borges 


\section{ANEXO B: Ficha Técnica da montagem de Calabar de 1980}

Disponível em: <http://www.chicobuarque.com.br/construcao/index.html>. Acesso em: ago. 2019.

Direção geral: Fernando Peixoto

Diretor assistente: Wagner de Paulo

Direção musical, arranjos e música de cena: Marcus Vinicius

Diretor de Cena: Paulo Carrera

Cenografia e Figurinos: Hélio Eichbauer

Elenco:

Sérgio Mambert: Frei Manoel do Salvador

Othon Bastos: Mathias de Albuquerque e Maurício de Nassau

Tânia Alves: Bárbara

Martha Overbeck: Anna de Amsterdã

Osmar di Pieri: Oficial Holandês

Gésio Amadeu: Henrique Dias e Papagaio Oba

Miguel Ramos: Felipe Camarão e Escrivão

Elifas Andreato: Agente da C.I.O.

e a participação em diversos personagens dos atores: Ariel Moshe, Dadá Cyrino, Édsel

Britto, Ina Rodrigues, Luiz Braga, Luiz Carlos Gomes, Mercedes de Sousa, Mônica

Brant, Samuel Santiago, Wilson Rabelo, Zdenek Hampl.

Músicos:

Magno Bissoli Siqueira: Bateria e Percussão

João Carlos Mourão: Contrabaixo e Violão

Fernando (Mu): Violão, Guitarra e Bandolim

Max Werneck Muniz: Flauta, Sax-soprano e Sax-tenor

Zeymar: Flauta e Sax-alto

Dagmar: Trompete

Equipe Técnica:

Produção executiva: Eliane Bandeira

Sócia gerente: Regina de Souza Malheiros

Assessoria administrativa: João Luiz Rossi

Divulgação: Sérgio Ascoly 
Coreografia: Zdenek Hampl

Sonoplastia: Cacá

Iluminação: Mário Masetti

Fotografias: José Rodrigues

Cartaz: Elifas Andreato

Programa: Alexandre Huzak

Camareira: Helena Lima da Silva

Maquinista: Paschoal Landi

Cenotécnico: João Tereza

Operador de luz: Adolfo Santana

Costureira: Alice Correa 
Anexo C - Iconografia do processo de encenação de Calabar (1973)

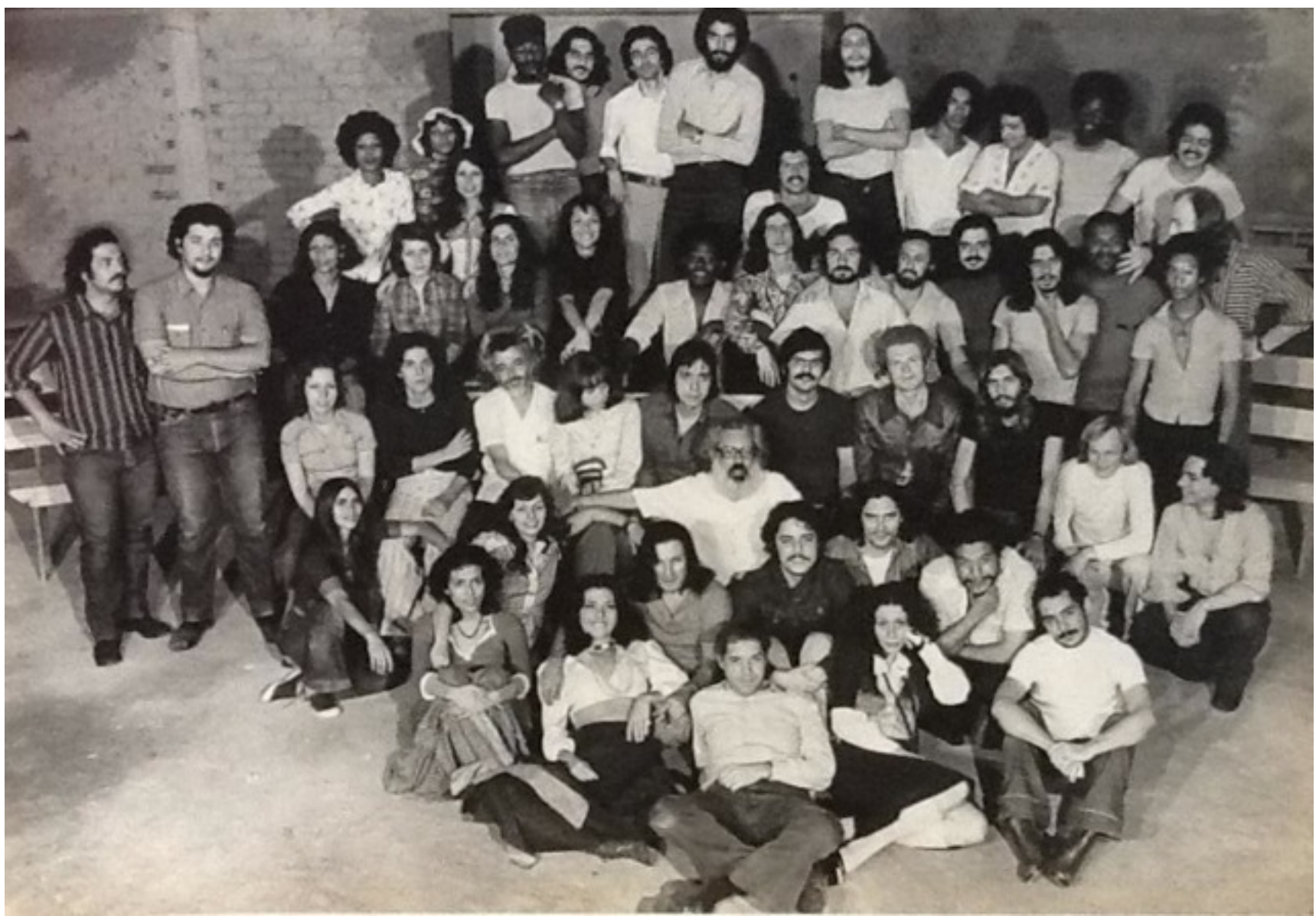

Figura 1: Fotografia da equipe de Calabar. Cedida por Mário Masetti. Essa imagem foi publicada no jornal Diário de Notícias do dia 4 de novembro de 1973, como parte de um artigo que divulgava a estreia que se aproximava. 


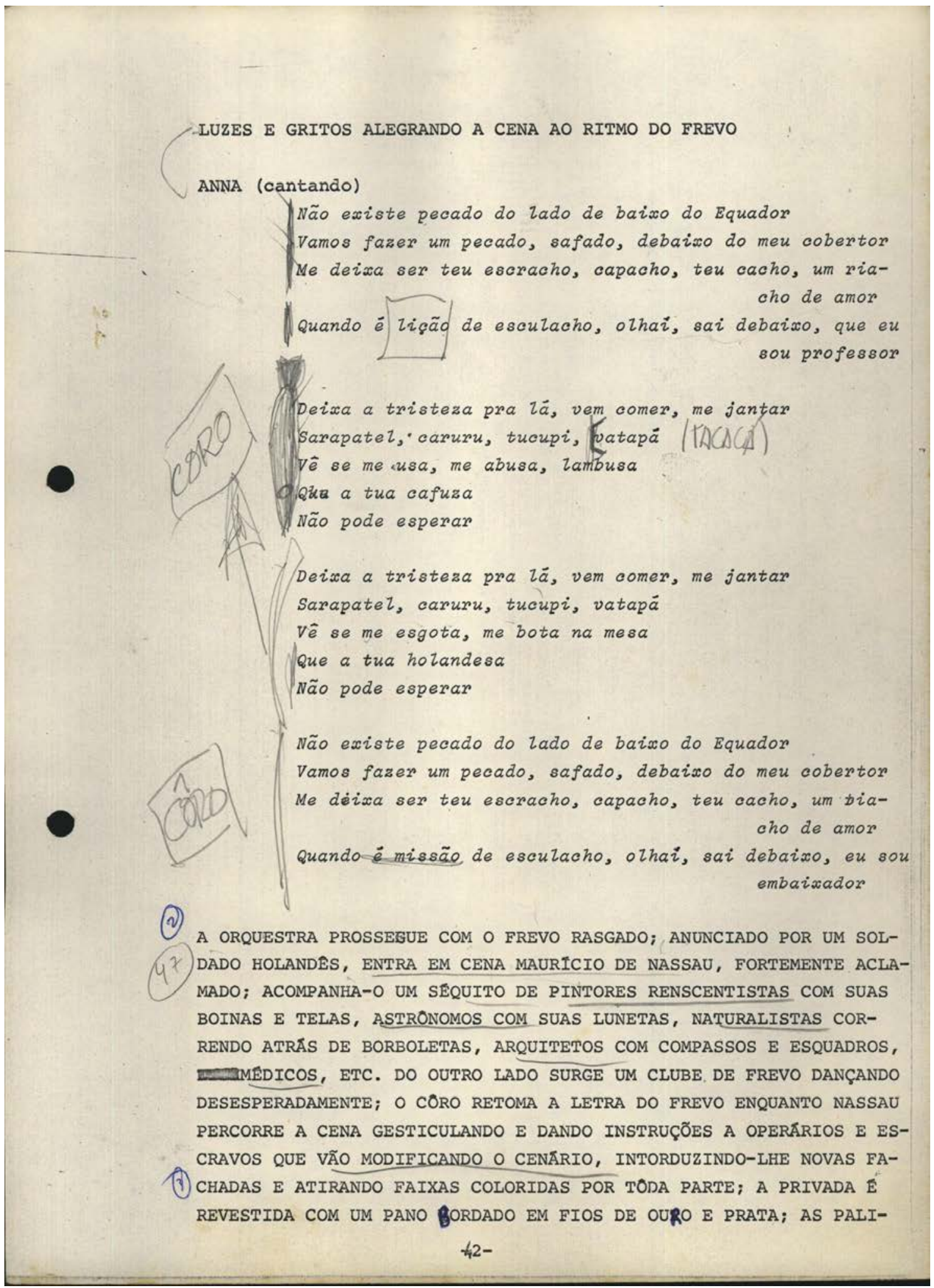

Figura 2: Primeira versão da dramaturgia com anotações de Fernando Peixoto. A palavra “Coro” aparece com grande destaque. Fonte: Arquivo Fernando Peixoto CEDOC - Funarte. 


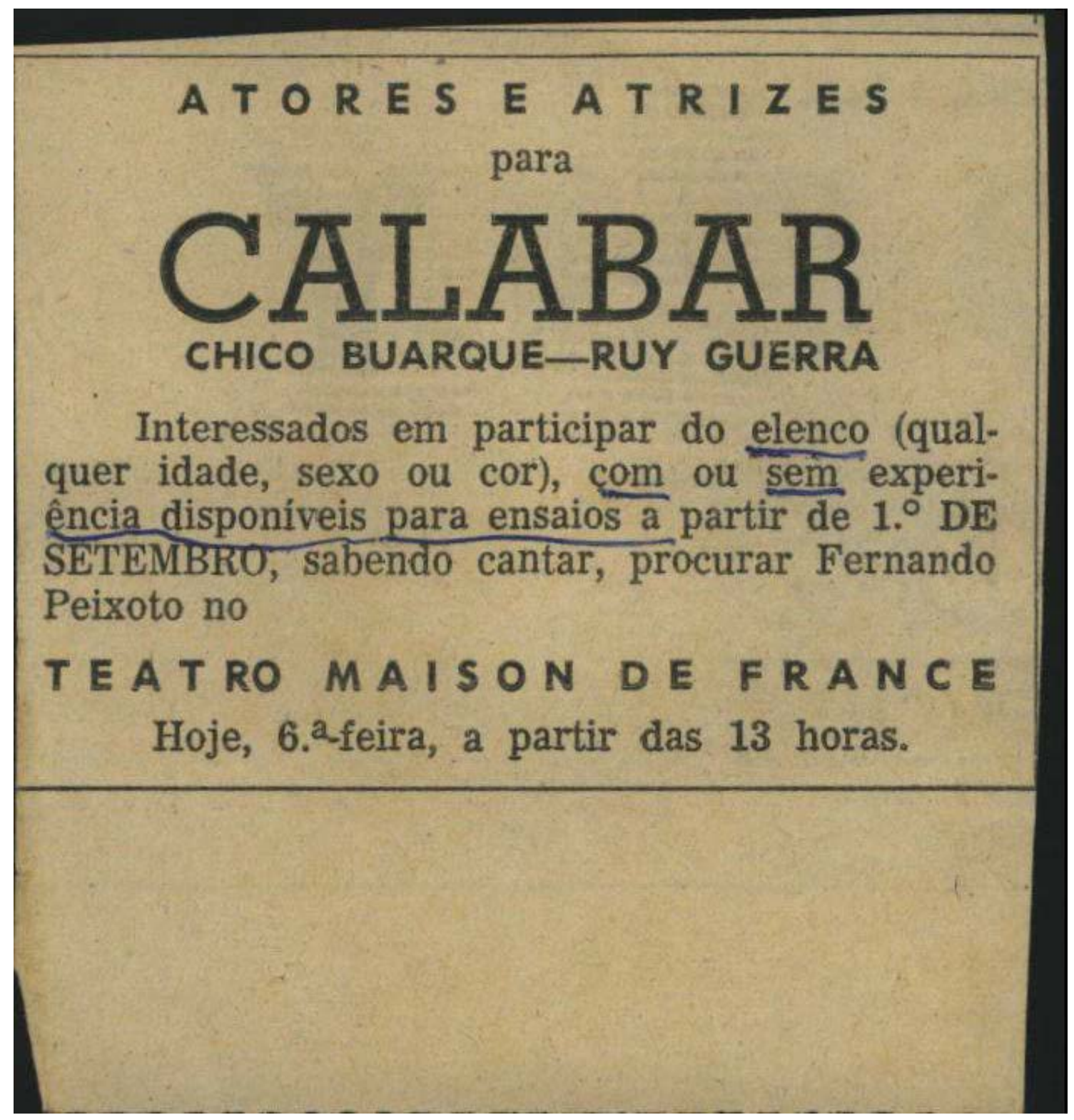

Figura 3: Divulgação dos testes de elenco para Calabar, publicada em jornal. Grifo a caneta presente no documento.

Fonte: Arquivo Fernando Peixoto - CEDOC - Funarte. 
FERNANDO TORRES DIVERSOES

ENTREVISTA PARA "CALABAR"

Nome:

Idade:

Endereço:

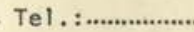

Experiências Anteriores:

Rua Firi Leandro, 29

Tel: $246-6632$

Rio de Janeiro - Guanabara

Figuras 4, 5 e 6: Registro da realização dos testes de elenco para Calabar.

Fonte: Arquivo Fernando Peixoto - CEDOC - Funarte. 


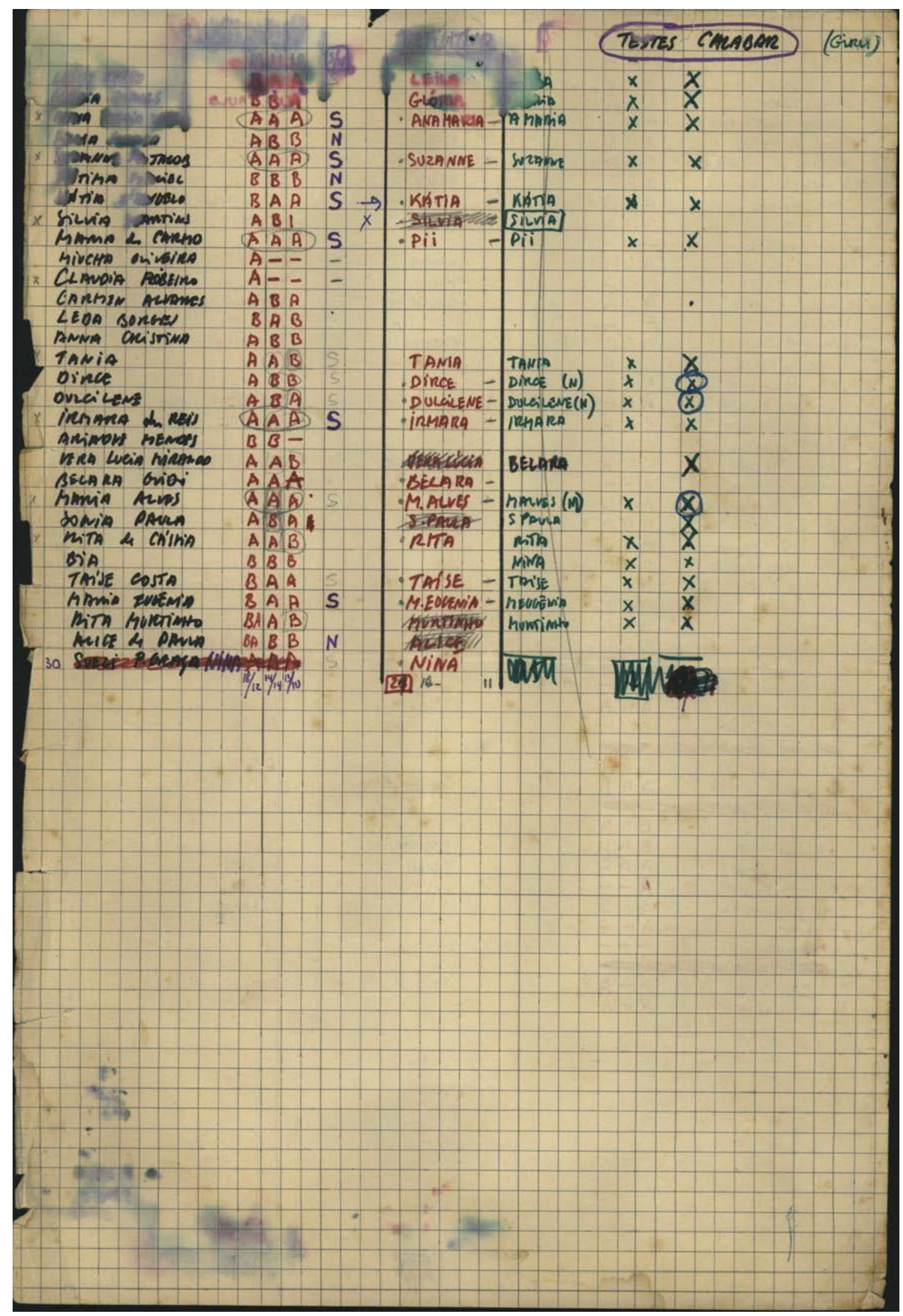




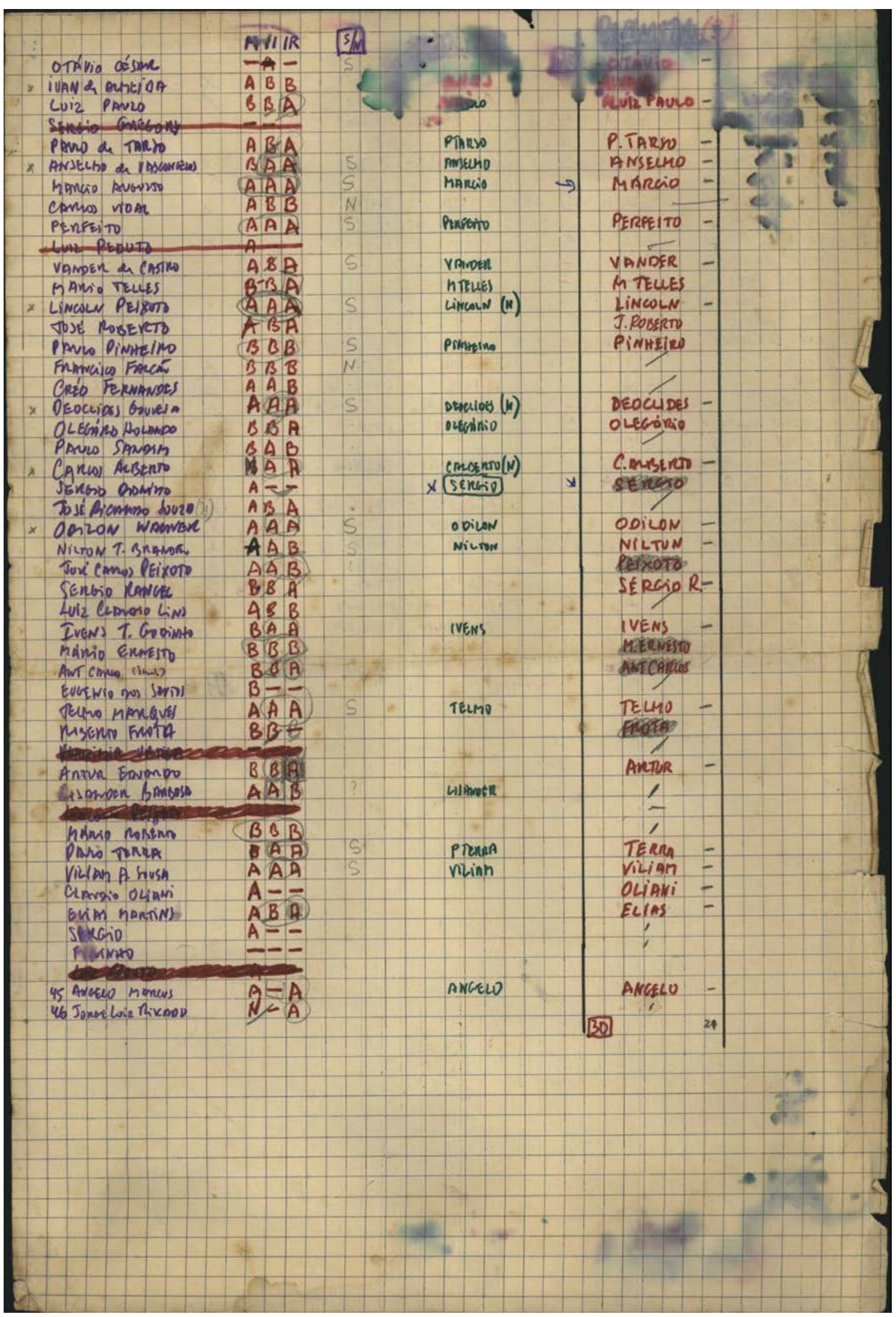




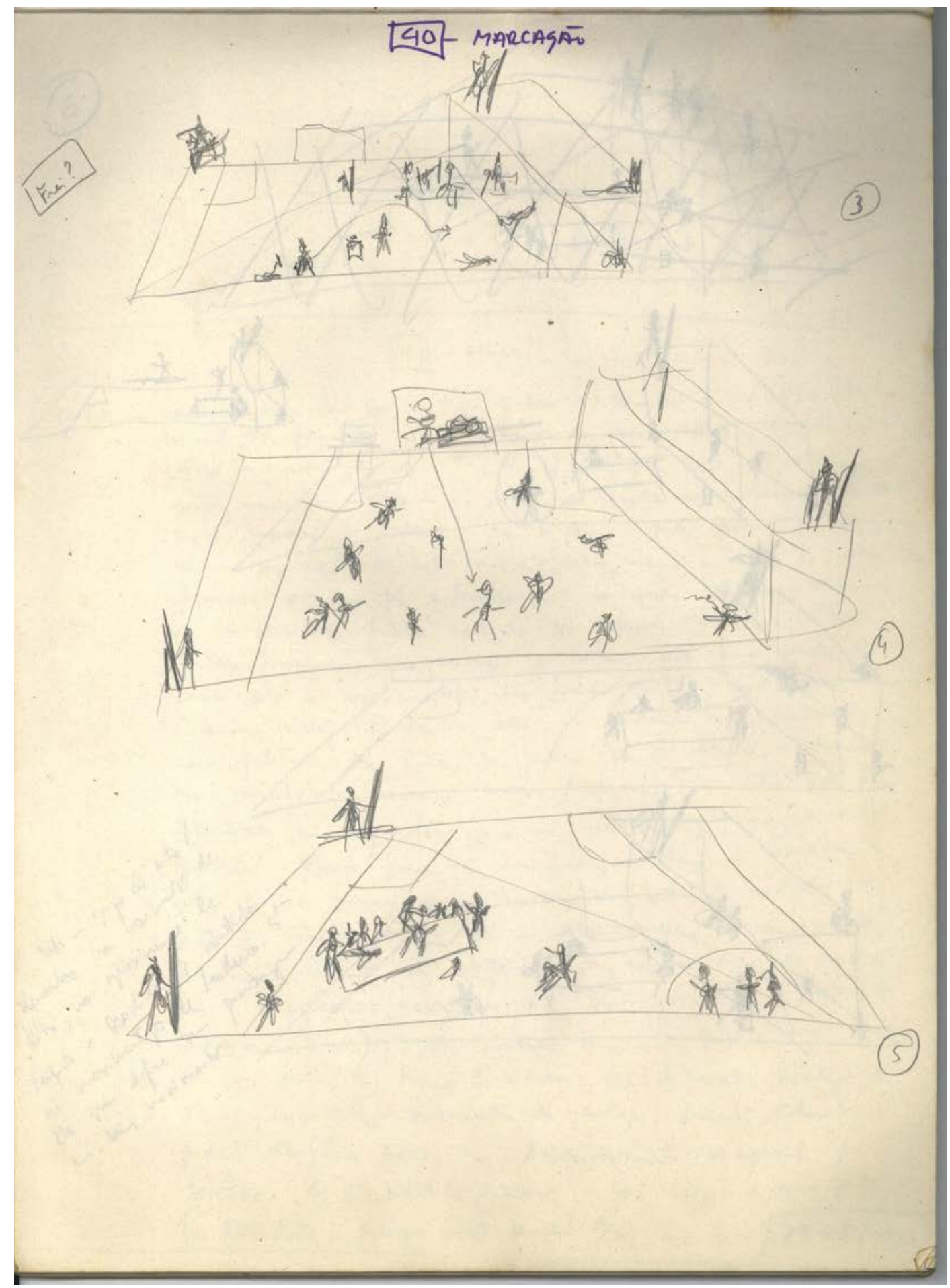

Figura 7: Registro dos ensaios de marcação presente no caderno de direção de Fernando Peixoto. Fonte: Arquivo Fernando Peixoto - CEDOC - Funarte. 


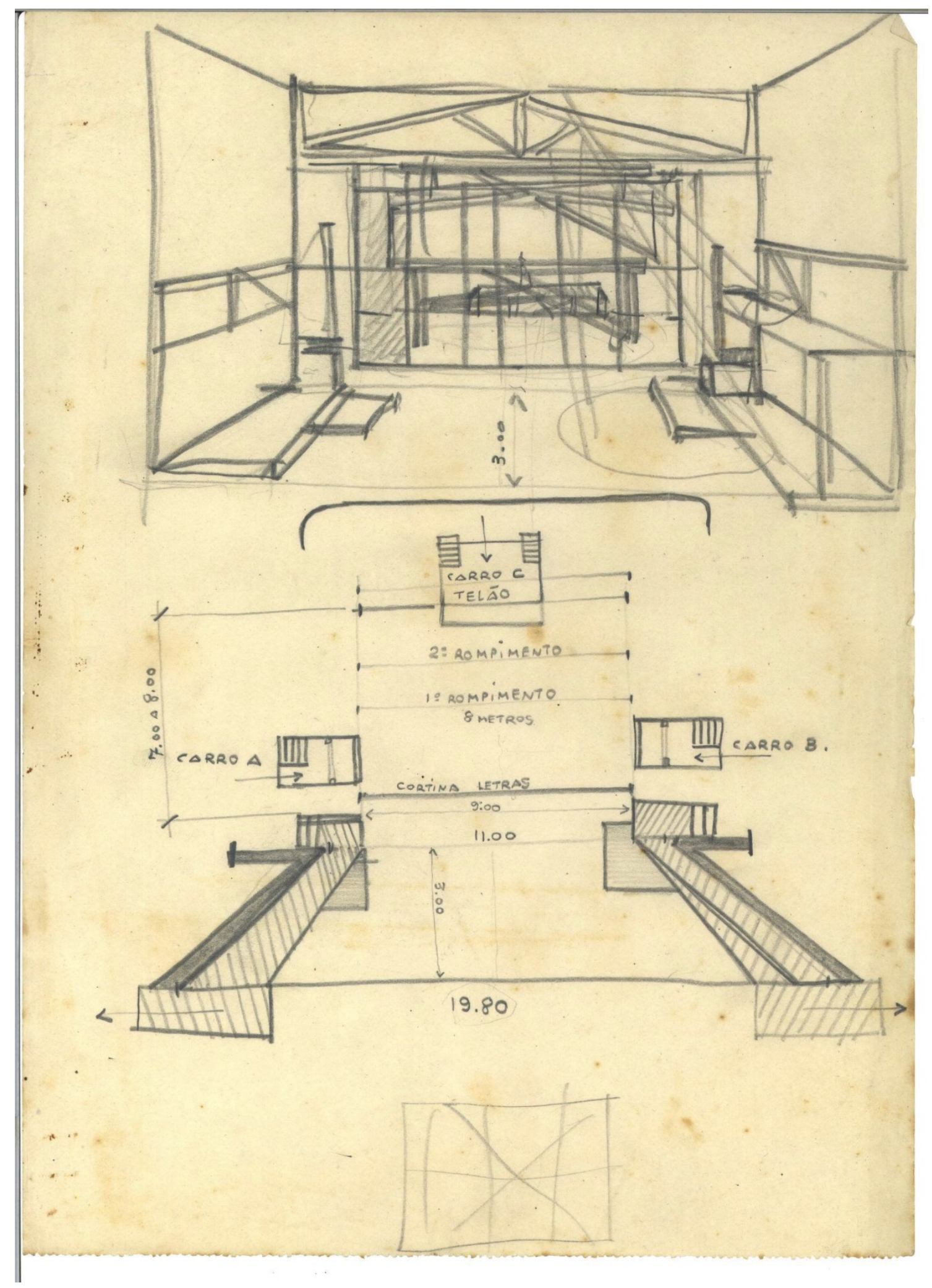

Figura 8: Estudo para a Cenografia. Fonte: Arquivo Fernando Peixoto - CEDOC Funarte. 


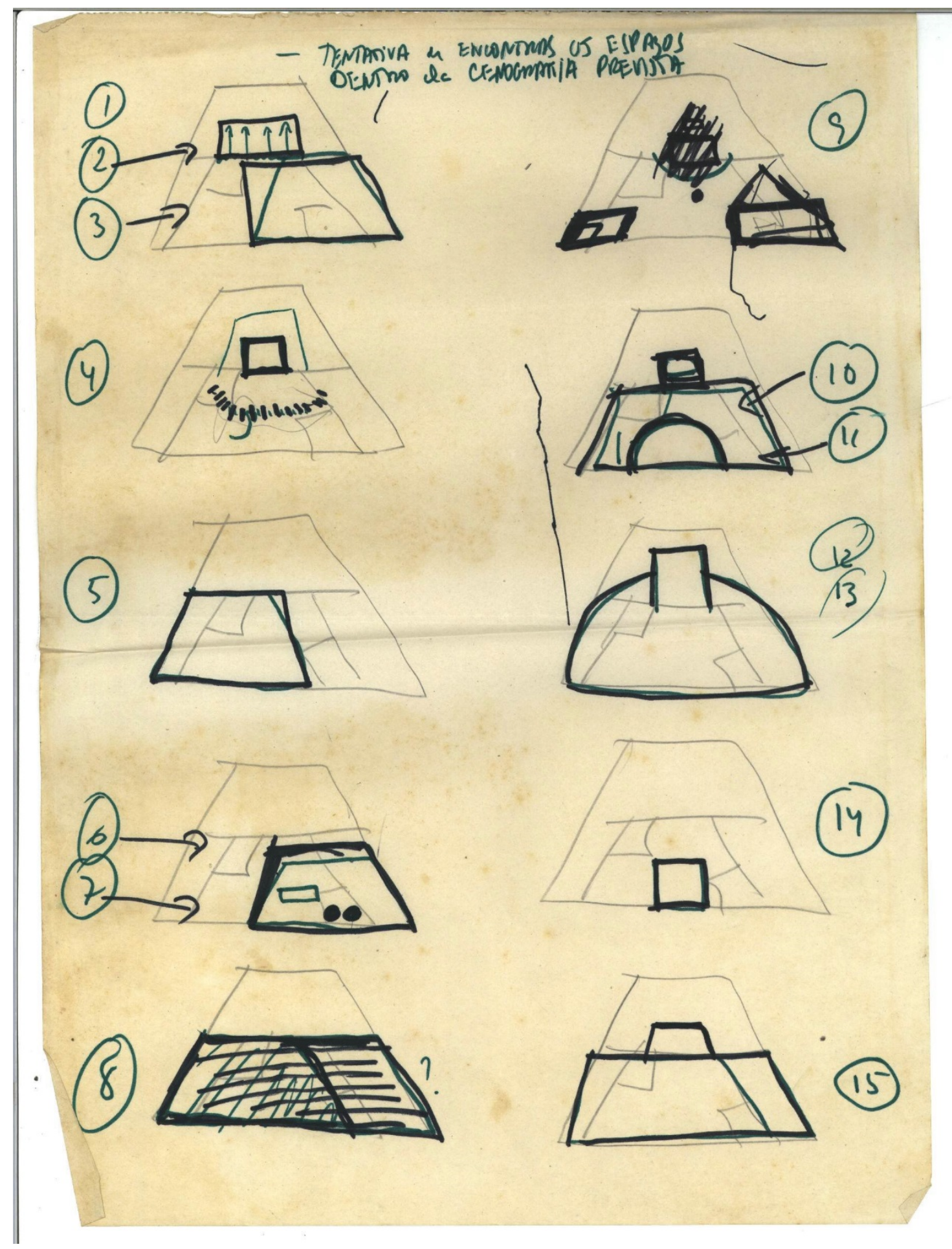

Figura 9: Estudo do Espaço Cênico: “Tentativa de encontrar os espaços dentro da cenografia prevista”. Fonte: Arquivo Fernando Peixoto - CEDOC - Funarte. 


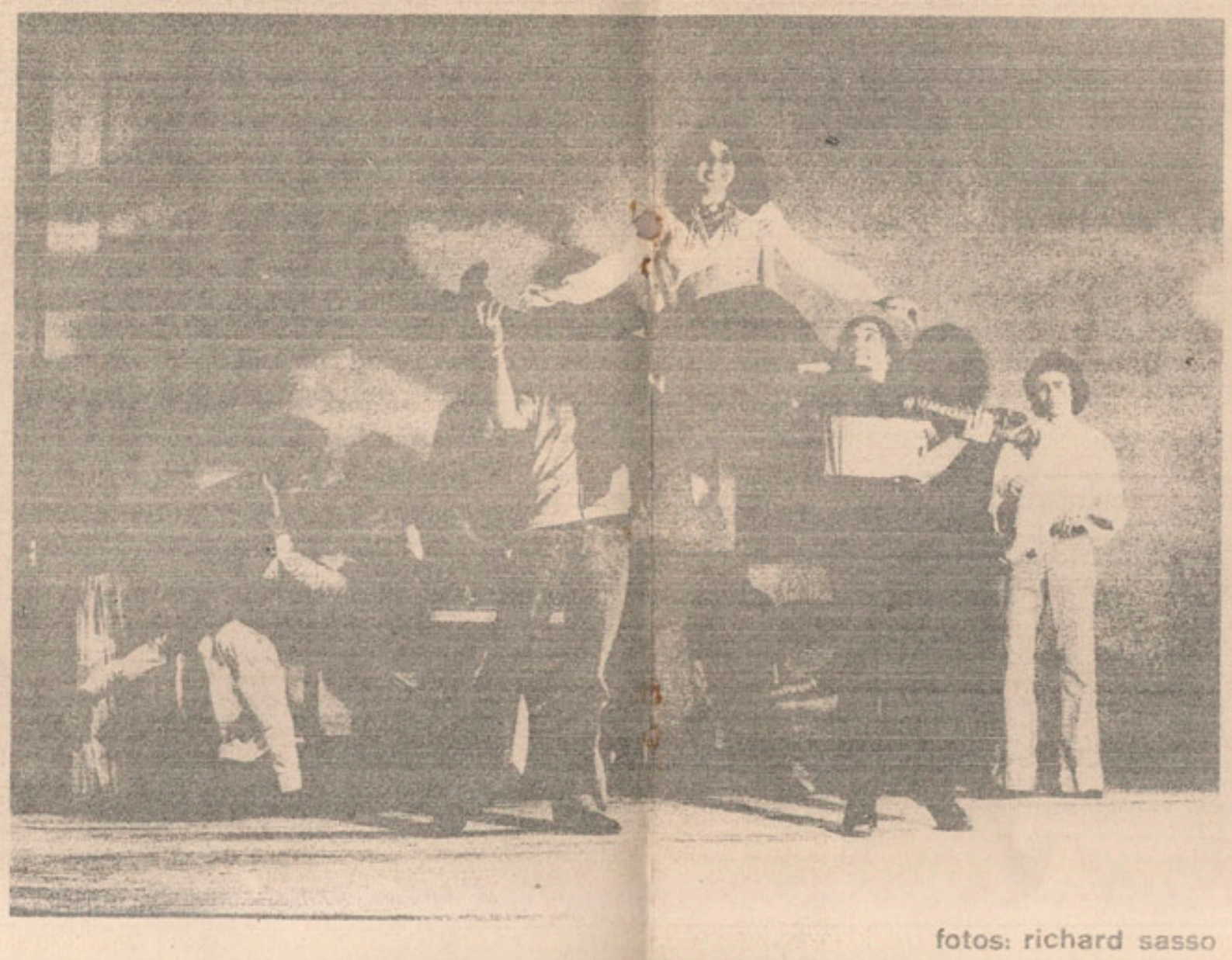

Figura 10: Betty Faria e coro. Fotógrafo: Richard Sasso. Publicado em: “Cala a Boca Bárbara (Chico Buarque e Ruy Guerra falam de Calabar)”. PUC / RJ DCE - 1973. Disponível em: <http://www.jobim.org/chico/handle/2010.2/2364>. Acesso em: mai. 2018. 


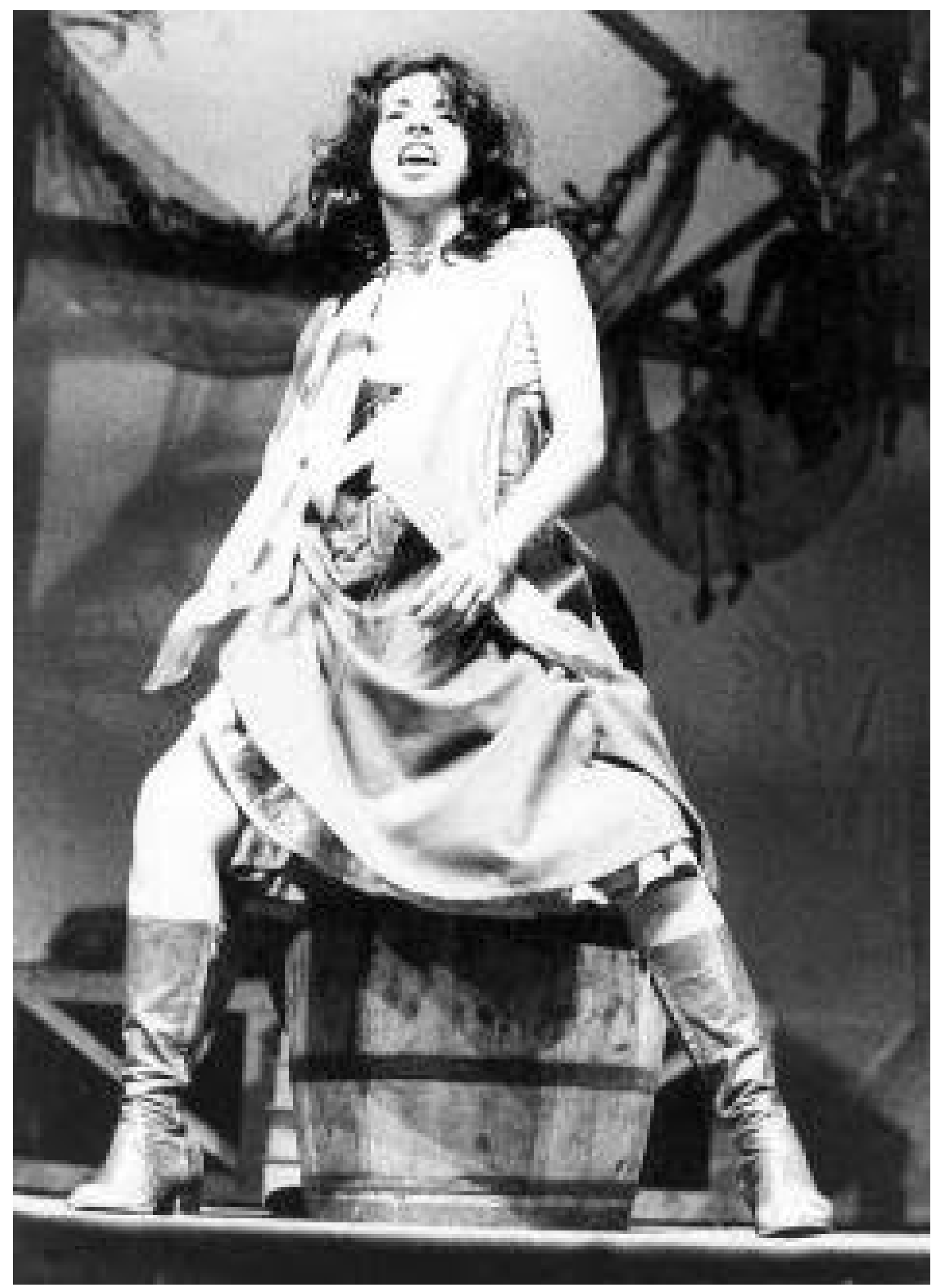

Figura 11: Betty Faria em cena. Disponível em: $<$ https://primeiroteatro.blogspot.com/2014/07/calabar-o-elogio-da-traicao-pormr.html>. Acesso em: mai. 2018. 


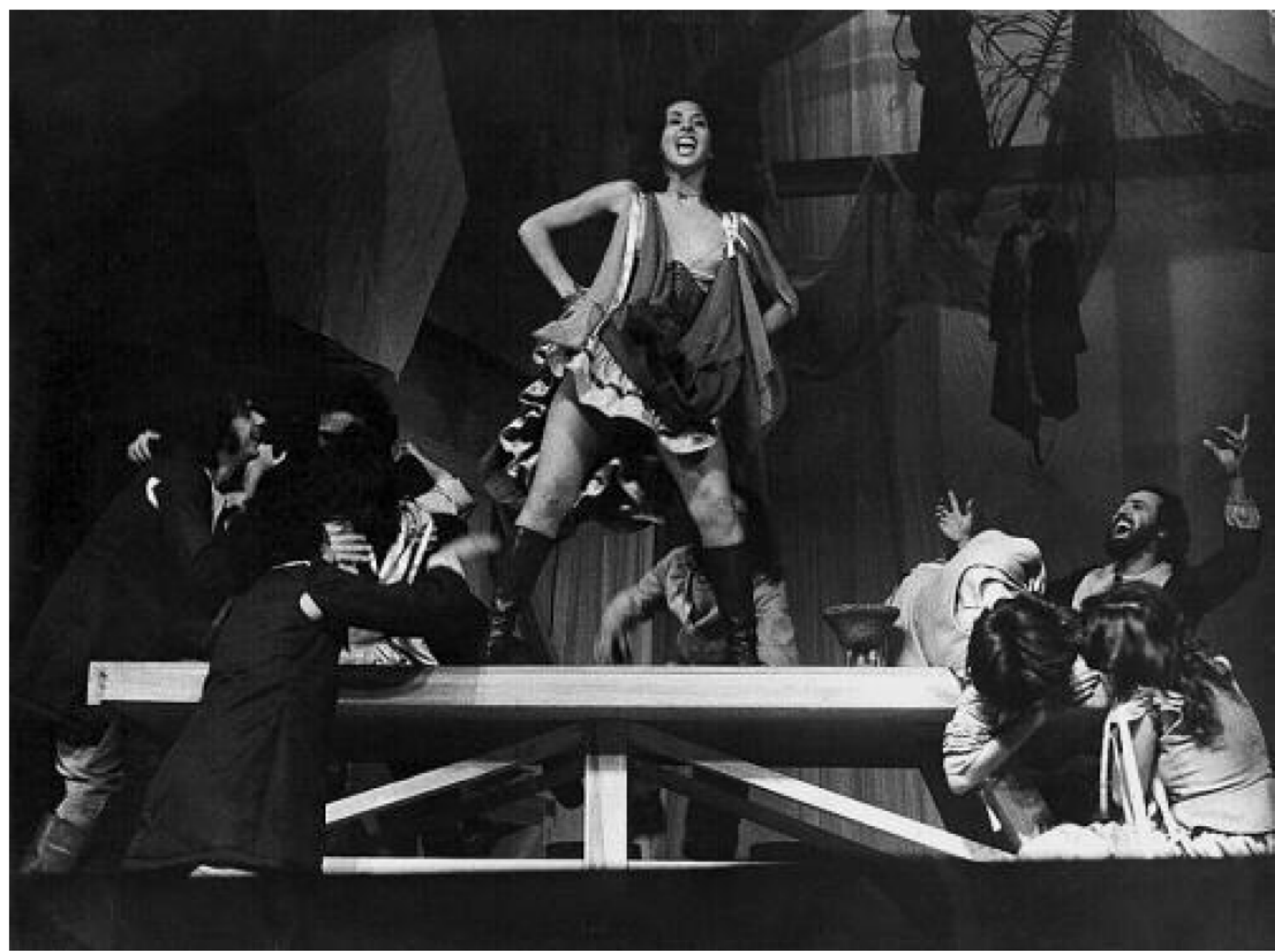

Figura 12: Betty Faria e coro. Fonte: MARTINS, Christian Alves. Rupturas e permanências: A recepção de "Calabar - o elogio da traição". Tese de doutorado pela Universidade Federal de Uberlândia. Uberlândia: 2014. 


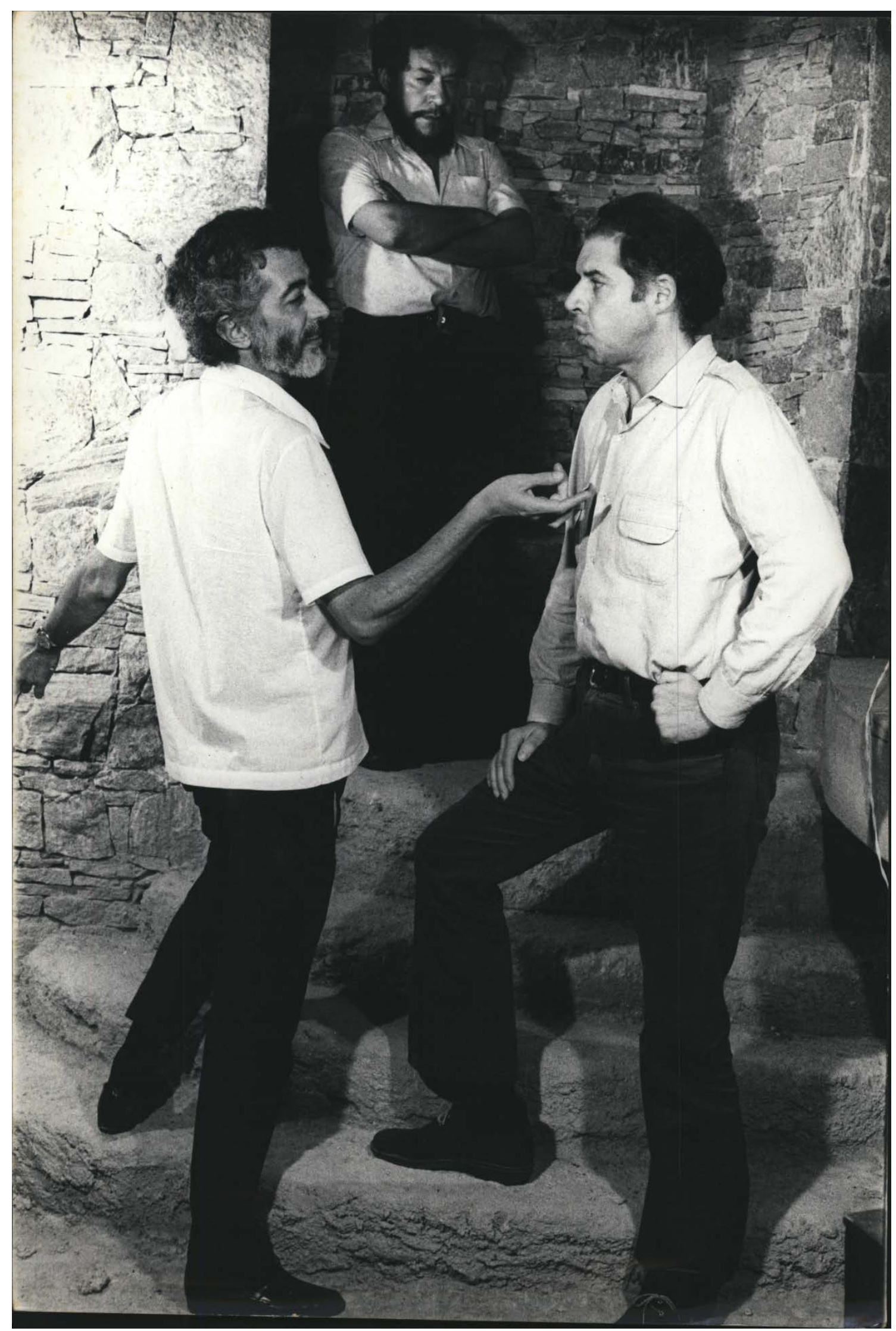

Figura 13: Hélio Ari, Antônio Ganzarolli e Lutero Luís. Fonte: Arquivo Fernando Peixoto - CEDOC - Funarte. 


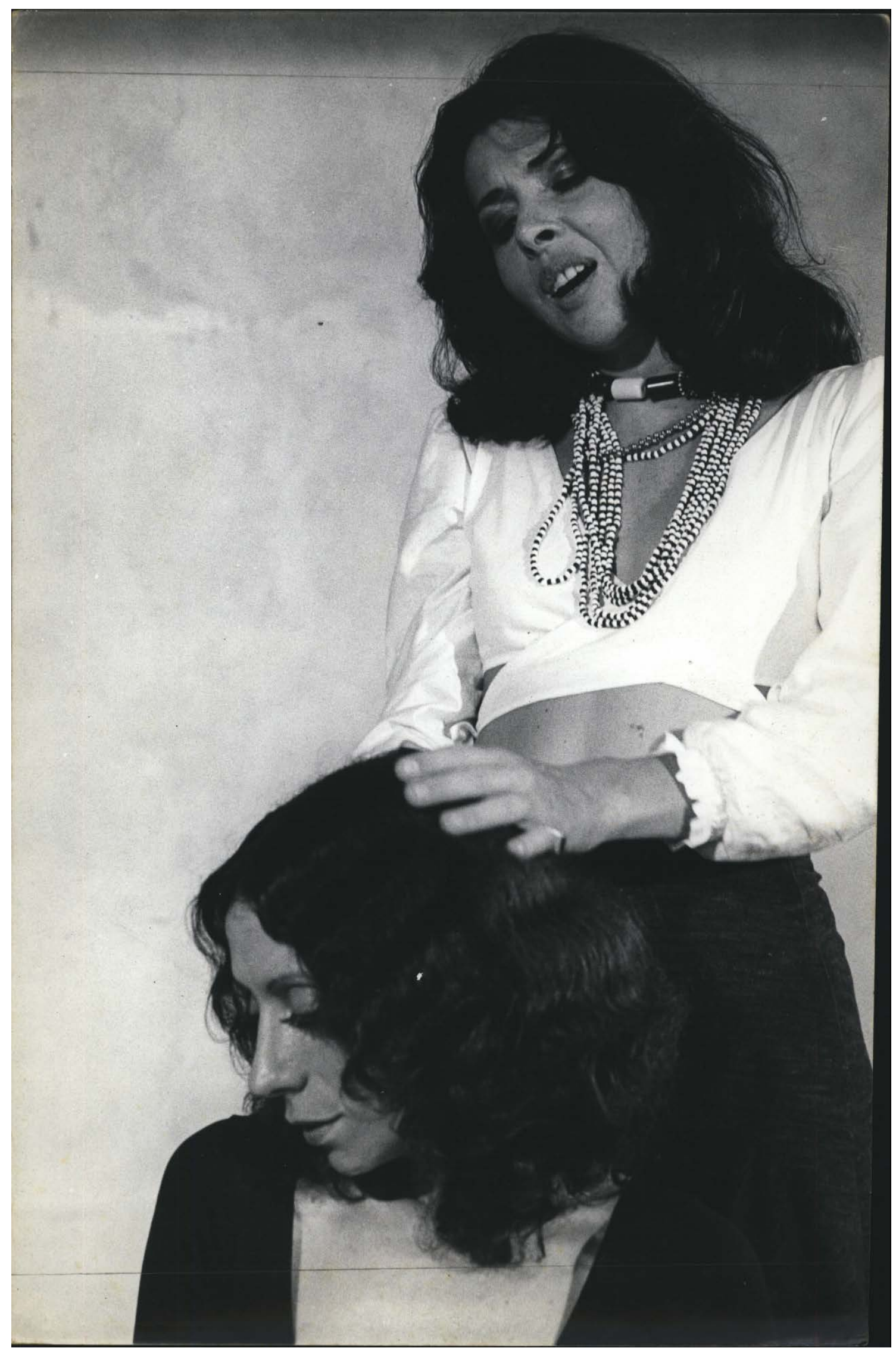

Figura 14: Betty Faria e Tetê Medina. Fonte: Arquivo Fernando Peixoto - CEDOC Funarte. 


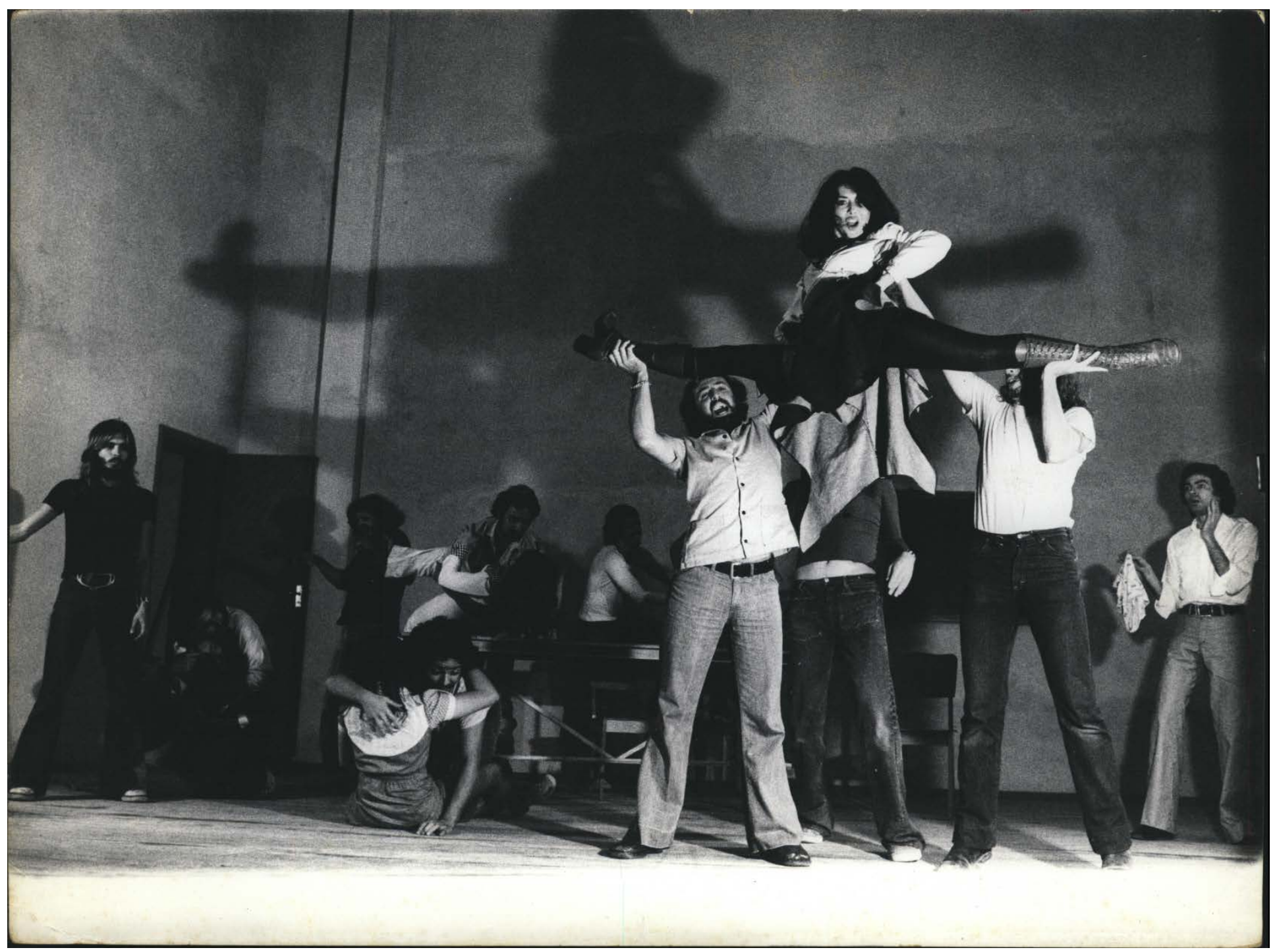

Figura 15: Betty Faria com Márcio Augusto, Suzanne Jacob, Anselmo di Vasconcelos, Maria Alves, Katia d’Ângelo, Paschoal Vilaboim, Ana Maria Vianna, Ângela de Marcus, Telma Marques, Paula Terra, José Roberto e Octavio Cesar. Fonte: Arquivo Fernando Peixoto - CEDOC - Funarte. 


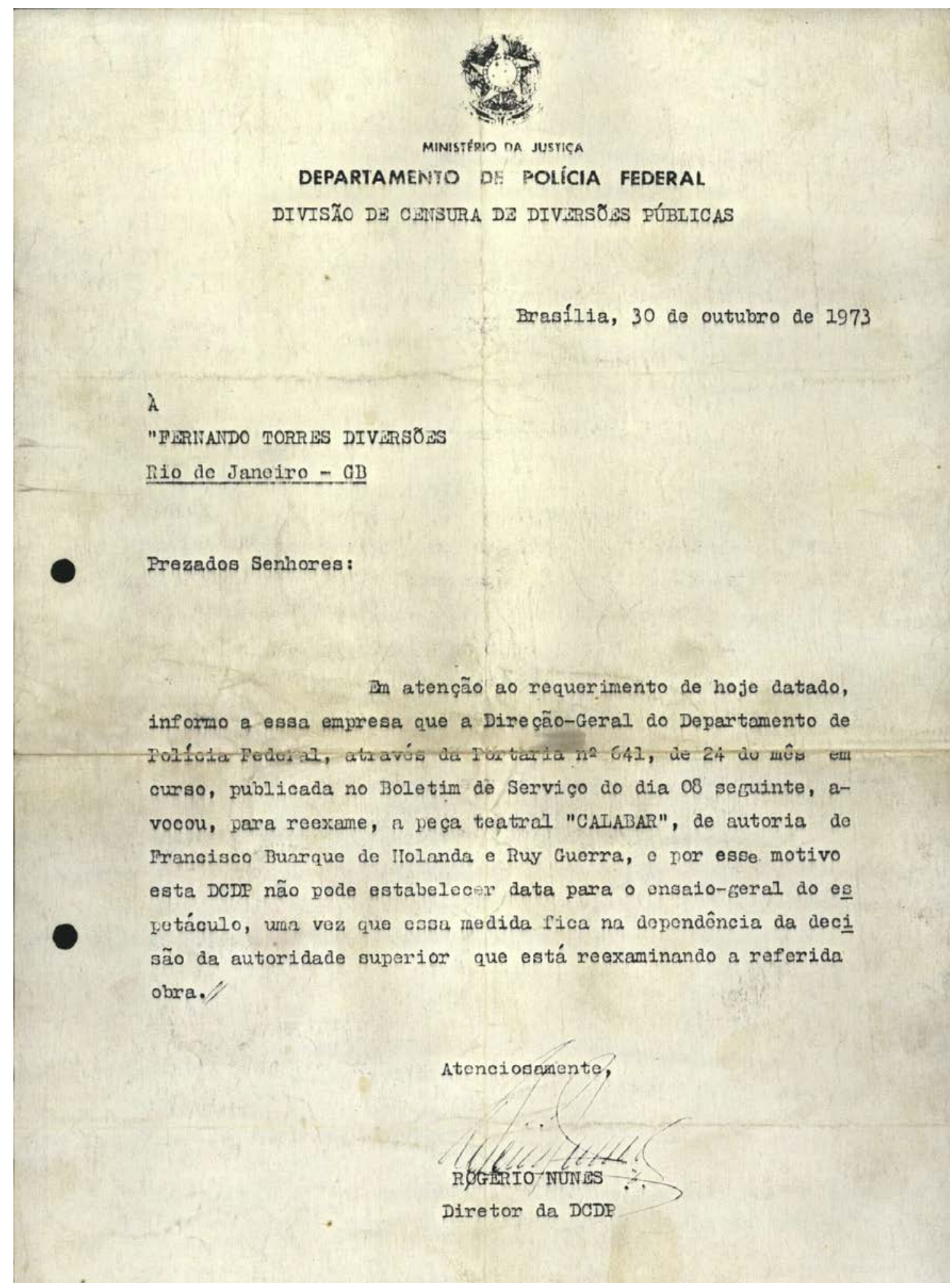

Figura 16: documento emitido pela Polícia Federal que afirma não ser possível estabelecer uma data para o ensaio geral do espetáculo, já que a peça foi “avocada para reexame”. Fonte: Arquivo Fernando Peixoto - CEDOC - Funarte. 
Quando nos propuzemos a promover a estréia universitâria da peça "Calabar", de Ruy Guerra e Chico Buarque, o fizemos considerando a importância cultural dos seus autôres. Neste momento em que a peça se encontra suspensa pela censura federal, o DCE da PUC-RJ não pode deixar de lamentar este fato, por ser negativo para nossa vida cultural e universitária.

Obs.Aos alunos que adquiriram ingressos, o dinheiro será devolvido. No entanto, havendo possibilidade da peça ser liberada dentro de 15 dias, aqueles que quizerem manter os ingressos por algum tempo, não haverâ problema, o dinheiro será devolvido da mesma forma apōs êste prazo.

DIRĖTORIO CENTRAL DOS ESTUDANTES

Rio de Janeiro, 8 de novembro de 1973.

Figura 17: Aviso do DCE da PUC sobre a suspensão da estreia pela censura, com a promessa de devolução do dinheiro de ingressos. Fonte: Arquivo Fernando Peixoto CEDOC - Funarte. 
Anexo D - Desenhos de Hélio Eichbauer para a encenação de Frei Caneca (1972 Direção de Fernando Peixoto).

Fonte: Arquivo Fernando Peixoto - CEDOC - Funarte.

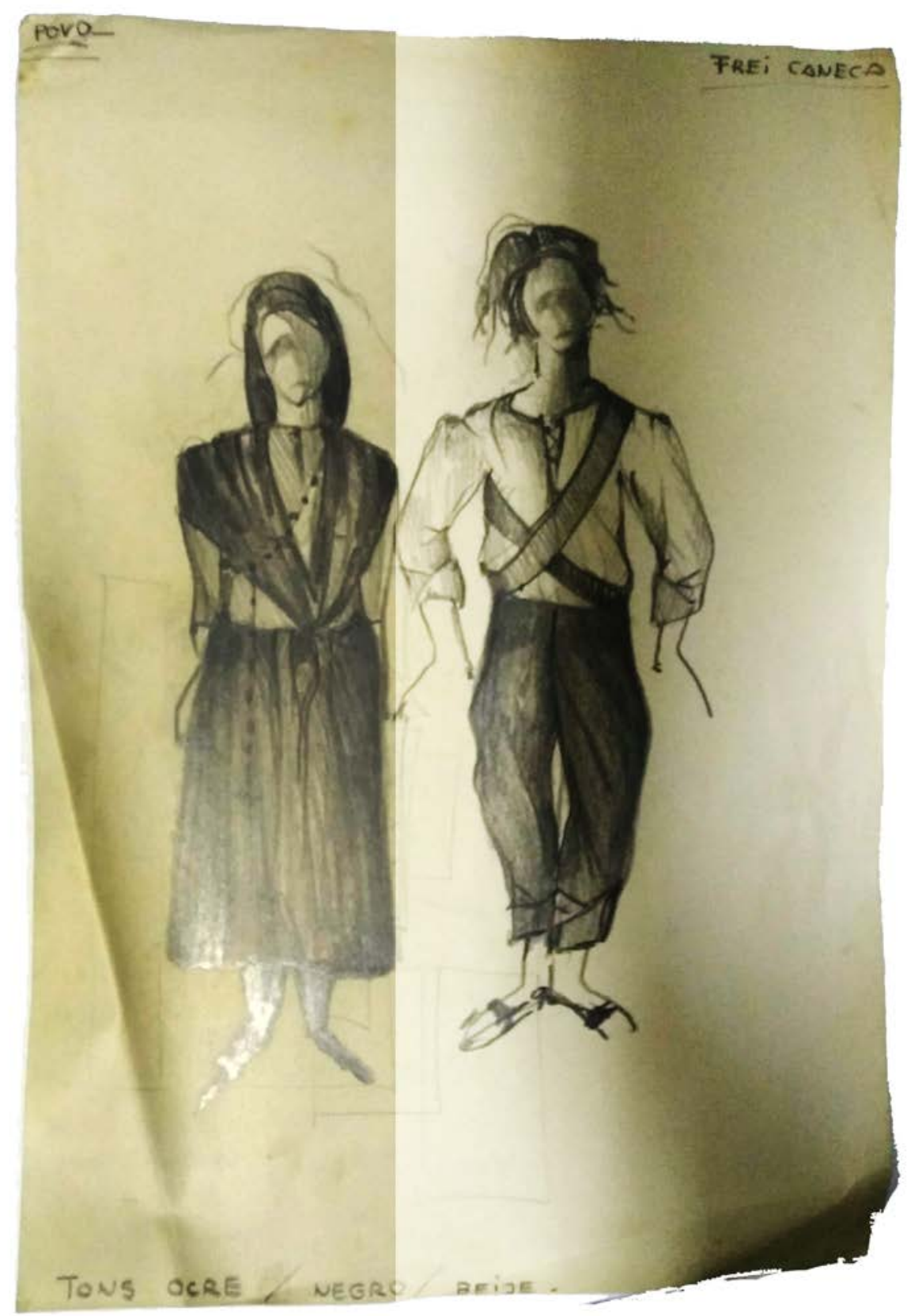

Desenho 1: Estudo para o figurino do Povo. Anotação: Tons ocre / negro / bege. 


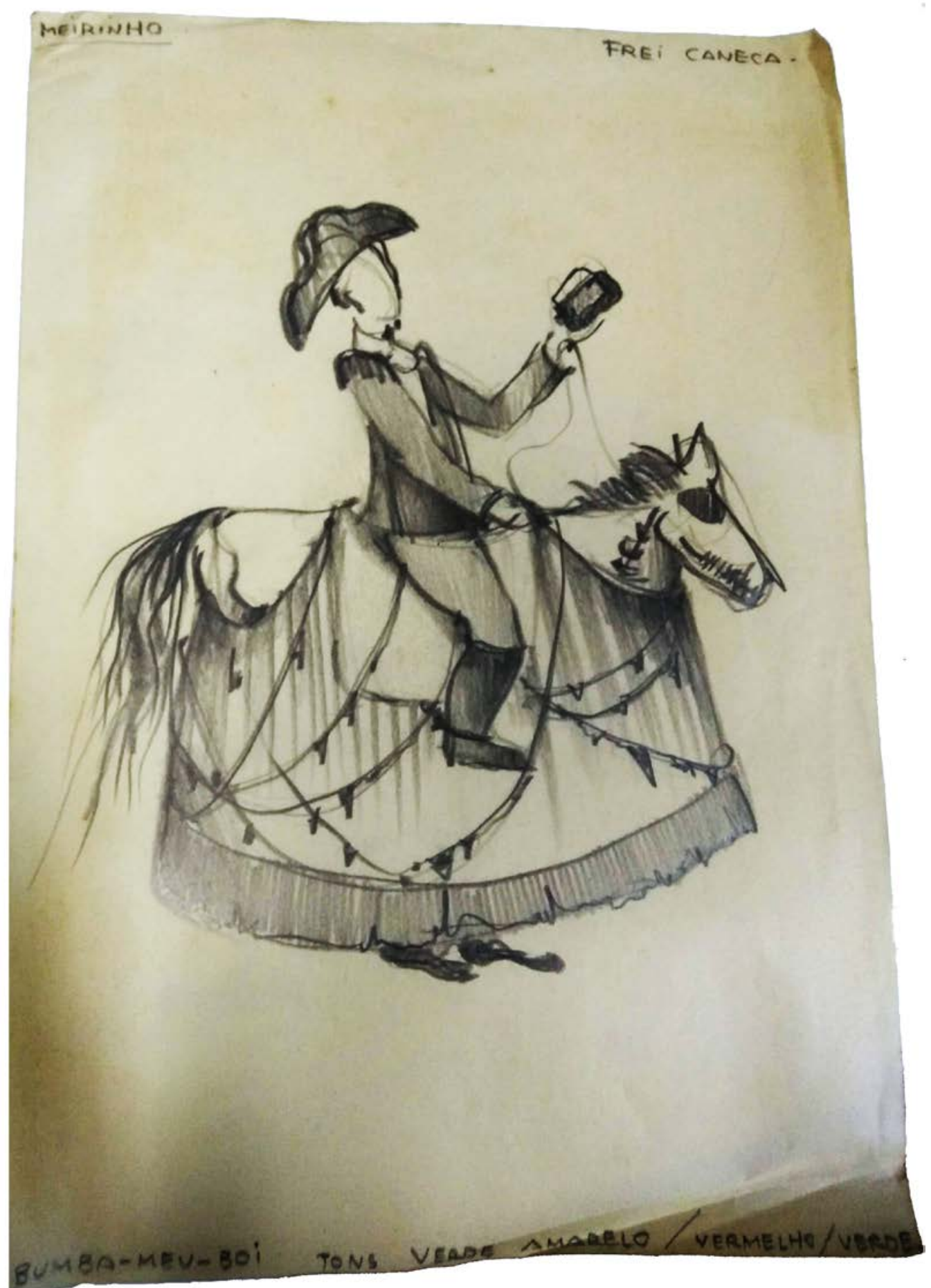

Desenho 2: Estudo para Meirinho. Anotação: Bumba-meu-boi. 


\section{ANEXO E}

\section{Diálogo entre Fernando Peixoto e Mário Masetti - 14 de novembro de 1973}

(Transcrição de fita cassete localizada no Arquivo Fernando Peixoto - CEDOC Funarte).

Fernando Peixoto - Primeira coisa que existe no espetáculo, acho, é que ele não ficou pronto. Que a gente precisou dar um empurrão final para uma série de problemas dele. Quer dizer, ele estava sem ritmo, ele estava um pouco arrastado, e com muitas cenas não resolvidas, tudo isso. Por outro lado, talvez, uma observação geral ainda, o pouco tempo talvez que tenha tido para trabalhar não deu para realizar totalmente a ideia de trabalhar o povo, trabalhar o coro que a gente chamava, coro no sentido de pessoas em permanente atividade, em trabalho. Seria vamos dizer assim a moldura - moldura não o pano de fundo do espetáculo inteiro. Isso consegui talvez até certo sentido, agora, não foi concluído. E também acho que no terreno geral toda a parte musical não foi trabalhada, tem que descontar. Faltou a instalação de som.

Mário Masetti - Essa parte do coro dependia muito da parte musical. Então acho que todo o tipo de apoio que existia, se possível, para esses elementos do coro, seria justamente cantar as músicas, que definia de certa forma eles.

Peixoto - O próprio cenário não se realizou até o fim. A gente tinha ideias para acrescentar no cenário a partir dos resultados dos primeiros ensaios corridos. Aquela ideia, por exemplo, de colocar bandeiras nas laterais dos cenários que não foram atingidas pela modificação quando entrava o Nassau, não é? Quando entrava a cor no espetáculo aqueles lados continuaram quase sem cor. E acho que isso podia dar um enriquecimento maior. O cenário tinha um problema só, que eu acho. Ele não era sujo o bastante, talvez, para dar a ideia da peça. Ele era uma definição de espaço muito claro, mas talvez a gente tivesse que trabalhar em cima de uma certa sujeira dele. Coisa que me vinha bacana quando tinha aqueles montes de feno, ou aqueles elementos, sacos, aquela coisa toda. Só que isso não chegou a ser dinamizado no próprio espetáculo.

E a parte musical, também, eu acho que tinha uma diferença muito grande entre o playback do Edu, que era um playback muito trabalhado, e inclusive que a gente teve discussões com o Edu - quer dizer, chegou a um resultado mais concreto ali, os arranjos estavam mais próximos do que a gente queria, em certo sentido. E os arranjos feitos 
pelo conjunto, pelos músicos ao vivo, não correspondiam no mesmo nível. Pela forma de trabalho mesmo, nesse sentido. Eu ia cuidar disso no final, eu pretendia cuidar, só que não houve tempo (claro, com as condições que a gente estava vivendo do lado da censura), não houve tempo de cuidar, eu acho, dos arranjos. Eu queria mexer, eu acho que só no arranjo de Cobra de vidro que eu cheguei a uma vez tentar um trabalho com eles. Aquela flautinha do Danilo que eu acho que ia funcionar. Mas não deu para trabalhar. Ficou uma parte incompleta. Toda a parte visual inclusive. A parte de figurinos... Eu tenho a impressão de que a gente nunca viu o espetáculo com o figurino completo, não é?

Masetti - Não. Nenhuma vez, nenhuma vez. Outra coisa que é importante é o negócio da iluminação.

Peixoto - A iluminação nunca foi realizada, a gente nunca teve uma ideia concreta de clima, nem de (vamos dizer assim) seccionar o espetáculo. Seccionar cenas no espaço. Poder iluminar umas e escurecer outras. Não houve um trabalho de iluminação, que poderia dar outra dimensão para a peça.

Masetti - Exato.

Peixoto - Então o que a gente está conseguindo julgar, talvez fazendo uma autocrítica nesse nível, é de um espetáculo não terminado. A partir de determinado momento a gente não conseguiu mais trabalhar por problemas de censura, na medida em que influenciou em termos econômicos (não tínhamos mais dinheiro para trabalhar) e também no psicológico, que a gente não conseguia... Embora tenha se mantido até o fim uma certa garra de trabalho e até uma certa confiança na liberação. Não deu para ter aquele tesão final, de levar a coisa até o fim realmente.

Masetti - Exatamente.

Peixoto - Eu queria tentar passar em revista o espetáculo inteiro, ver mais ou menos como seria. Eu acho o início legal, sem problema nenhum, quer dizer, dependia fundamentalmente da música e do cenário. Agora, o Miserere nóbis que entrava em seguida acho que foi legal também, com a ampliação do som ele ia dar um resultado que não se tinha.

Primeira cena, Mathias escrevendo a carta. Ela nos últimos ensaios conseguiu chegar a ter um ritmo razoável. Eu achava bacana, muito bacana mesmo, a distribuição de espaço da chamada figuração. Ainda que eu ache que faltava talvez caracterizar até o fim o que seria o exército português, a chamada resistência. Sei lá, talvez mais presença de índios. 
Havia talvez até um excesso de mulheres. Não, não havia um excesso de mulheres. A ideia de pôr mulheres no exército eu achava bacana. Mas talvez existia uma falta de mais homens, não é? A gente tinha uma limitação de elenco nesse sentido. Se bem que eu acho que o quadro geral que abria dava uma imagem de acampamento. E acho que transmitia um pouco a ideia social da cena. Talvez pudesse obter um resultado melhor do Hélio ainda, trabalhando mais as falas dele que são difíceis.

Masetti - Uma coisa que eu acho bacana a gente colocar é o tipo de elemento que a gente buscou que desse a imagem de um acampamento militar português da época. Então, todo aquele tipo de trabalho que a gente fez com chamada a figuração. Aqueles exercícios de acampamento e tudo isso. Conseguimos chegar a um cozinheiro. Um casal...

Peixoto - Pois é, por exemplo a Maria Alves que paria, estava com dores do parto na hora do acampamento. Era uma ideia bacana, talvez pudesse ser mais desenvolvida ainda. Mas se tinha de todo o jeito. Se tinha o cozinheiro, se tinha a mulher parindo, se tinha um casal meio de sentinela meio abraçado, se beijando. Tinha aquele sentinela de escudo e armas em cima, mais lugar comum, mas era bonito - inclusive visualmente. Eu acho que a cena passava a ideia da perplexidade do cara trair e tudo, só acho que talvez tivesse trabalhado um pouco mais no Hélio, com mais tempo. A fala dele é muito longa, muito grande, muito difícil, essa fala em verso. Mas acho que no nível da figuração a gente conseguiu um resultado bacana. O cara do espelho eu achava bonito, o Marsal (?) [falas sobrepostas] inteiramente caído, de joelhos, sei lá, com aquele espelho levantado. E o escrivão que surgia pela primeira vez, que acho que também desempenhava um resultado. E o prisioneiro torturado.

Masetti - Exatamente.

Peixoto - Os soldados meio bêbados, tudo isso. Eu acho que isso dava um quadro bacana. Essa primeira cena eu achava que funcionava bem. A segunda, eu acho que se a gente conseguisse talvez um pouco mais de exagero nos movimentos, quer dizer, teatralizar mais os movimentos de trabalho da arraia miúda... E talvez conseguir que a Tetê fizesse uma coisa um pouco mais... Se bem que era bonita essa primeira parte dela. Às vezes tinha uns certos movimentos de dança que ela fazia que não me agradavam muito. Mas que acho que a gente podia corrigir pouco a pouco. E de qualquer jeito ela cantava muito bem a canção. O Cala a boca Bárbara. 
Masetti- É, pelo menos a ideia fundamental, que era a Bárbara assumindo Calabar no corpo dela, contrapondo com o povo trabalhando numa situação de clandestinidade, por enquanto.

Peixoto - É, e aquela ideia do povo trabalhando isolado, quer dizer, eles não eram um conjunto. Eles trabalhavam isoladamente. Então o povo teria três momentos. Três arraias miúdas. Nesse momento ele funcionaria isoladamente, trabalhando em pontos isolados do espaço cênico. E na segunda aparição da arraia miúda estavam juntos, e na terceira eles formavam uma espécie de barreira de passeata já no nível político, já mais juntos no nível político, já se dirigindo diretamente ao público.

Masetti - Exatamente.

Peixoto - Nesse momento eu achava muito bonito a diversidade de trabalhos que se conseguiu, o resultado era bom. E acho que passava a ideia também da canção de amor ao guerreiro, ao guerrilheiro ... “Ele é meu guerreiro”, não é?

Masetti - Exato.

Peixoto - A canção de amor mesmo, não é? Feita por ela ao homem dela. Inclusive nunca se levou até o fim a ideia de deixar ele nu ali, e tudo isso. Também não se fez uma coisa que eu achava bacana que era o negócio de ela se vestir. Ela deveria surgir nua nessa cena. Era muito bonito se a atriz surgisse nua e fosse se vestindo durante a introdução da música, e aí começasse a cantar. Isso não foi concluído.

Masetti - Eu queria ressaltar também o tipo de trabalho do povo, o tipo de trabalho que foi escolhido durante os ensaios. O camarada martelando, trabalhando com o martelo, esse tipo de trabalho mais braçal...

Peixoto - É, o cara limpando armas, que já era uma indicação de uma coisa seguinte. Mas as armas deveriam voltar na cena seguinte. Na última principalmente, não é?

Masetti - Exatamente.

Peixoto - Era uma constante que deveria ter se colocado. Principalmente no Cobra de vidro, que era a terceira aparição da arraia, todo mundo deveria estar armado pra passar a ideia de maneira real. Ou transformar os instrumentos de trabalho em armas, ou então ter armas mesmo.

Masetti - Exatamente. O que de certa forma seria bem simples... [Falas sobrepostas]. Porque tem o que corta a cana, o facão... 
Peixoto - Pra conduzir a ideia que estaria por trás do Calabar revolucionário. Quer dizer: não ele Calabar revolucionário. Mas enfim, a opção brasileira que não existe na peça poderia talvez ser encarnada na arraia miúda. Não sei.

A cena da orgia holandesa, talvez tivesse faltado gente pra caracterizar o acampamento militar holandês. E tinha uma ideia que eu tinha aí que eu nunca fiz, não deu pra fazer. Era um momento que eu sentia que podia talvez se utilizar gente passando com sacos de açúcar por trás da cena, entende? Para não mostrar só a orgia, mas mostrar que por trás daquela orgia tinha uma movimentação de trabalho e de saque. Quer dizer, o açúcar sendo transportado por escravos.

Agora, a orgia funcionava muito bem, por causa da marcação do Zdenek toda. E a dança da Betty eu achava bacana. E acho que sobretudo nessa cena tinha uma coisa que me agradava que era o ritmo que a cena dava. O ritmo de sacanagem que a Betty dava na canção. Eu acho que uma coisa que não ficou clara era distinguir exatamente o comportamento dos moradores portugueses católicos em relação aos soldados holandeses calvinistas, e o pessoal que não dava a mínima importância para a religião. Mas acho que a cena passava nesse sentido. Claro que com Odilon no papel do holandês a gente não conseguiu nunca o nível de cafajestice talvez que aquele personagem tivesse. Que era uma das alternativas do personagem, podia ter outras. Mas era uma espécie de pré-Nassau. Agora, na parte final da cena eu gostava, acho que a apresentação super funcionava, não sei.

Masetti - A entrada do Souto.

Peixoto - É. Que a cena ficava vazia, com os três personagens, a Anna deitada na mesa, e os três personagens. Enfim, era o momento que se via na cena a traição, o Souto traindo, traindo os holandeses e entregando Porto Calvo nas mãos dos portugueses. E eu achava bacana nesse sentido certas coisas que o Flávio fazia, que era de comédia mesmo, do relacionamento dele com o Frei, quando ele envolvia o Frei na traição. Principalmente aquele final, que o Frei dava a mão pra ele beijar e ele dava um beijinho na mão, na base de: “Tem que beijar, é? Então tá legal, então eu beijo”. E dava um beijo muito sem graça, muito não religioso, e em seguida dava um pontapé na bunda do Frei. Ou tapa nas costas, ele variava.

Masetti - Exatamente.

Peixoto - Isso acho que funcionava. 
Masetti - É bacana ressaltar também a função da música cantada pela Anna de Amsterdam, que a Betty conseguiu fazer muito bem. Que era uma espécie de resumo ideológico da cena toda.

Peixoto - "Quando perco alguma guerra / Eu não perco a profissão / Muda só minha bandeira/ Como muda o rufião”.

Masetti - Exatamente. Toda a primeira parte. "Eu dormi com um protestante / E um católico depois / Mas a mim ninguém garante / Qual é o melhor dos dois”. Eu acho que isso que é um resumo ideológico podia ser passado também muito mais pelos moradores.

Peixoto - Pelos moradores, é.

Masetti - De certa forma, não sei...

Peixoto - Estava muito junto aquilo tudo, não é?

Masetti - Estava num nível de porre só e que não tinha... Não se assumiu, acho uma postura ideológica de morador senhor de engenho.

Peixoto - É, o comportamento dos moradores frente à situação: isso não ficou claro. Os três heróis eu achava muito legal a forma deles se apresentarem como trio de vocalistas, um negócio de filme da Atlântida. Eu acho que ridicularizava bastante a ideia dos heróis, e a música ajudava demais. Sobretudo o jeito que o Flávio cantava, era uma forma mais brechtiana de cantar, ele quebrava a música no meio, que é um sambão.

Masetti - Exatamente.

Peixoto - Depois a cena toda do Hélio, o fado, eu acho que faltava nessa cena a movimentação do acampamento. Eu acho que essa cena devia ser uma preparação de guerra, uma preparação do ataque. Talvez se pudesse com mais tempo trabalhar nesse sentido. No final eu já pus o Paschoal na cena, e tal. Eu queria mais dinamizar a cena, no sentido de mostrar o acampamento se preparando, entende? Para atacar. Enquanto ele canta o sonho colonialista lá dele, "Essa terra ainda vai cumprir seu ideal / Ainda vai tornar-se um imenso Portugal”. Essa cena tinha um negócio, eu às vezes tinha certas dúvidas, achava a cena meio parada, não sei o que você achava. Mas eu achava que ela parava, e que o texto da canção levava adiante.

Masetti- Exatamente. O que eu acho, quer dizer, a tentativa... A tentativa não: o que foi feito em termos de abrir a cena mais, conseguiu dar a dinâmica apesar de todo mundo... de ser realmente uma cena parada. 
Peixoto - Ela parava, ela ficava estática, porque ficavam os três caras na mesa... Os soldados, dois negros, e o gua... o [inaudível] na parte de cima, e o Paschoal no canto de cá, que era o [inaudível].

Masetti - É, mas de qualquer forma...

Peixoto - Mas ficava parada de propósito. Eu acho que naquele momento o negócio era parar pra ver a canção, e pra ouvir a canção, e ver a letra. Eu estava confiando muito na [falas sobrepostas] junto ao público.

Masetti - E a apresentação dos heróis, e tudo isso. Tinha a ideia original que era em cima da nota de 500 cruzeiros. Era baseada na nota de 500 cruzeiros.

Peixoto - Verdade. Que era o brasileiro, o índio e o negro. Bom, aí tem a latrina. A latrina é uma cena que tinha que funcionar com o público. Eu acho que ela estava bem resolvida, ela não tinha nenhum problema. O problema era dar ritmo. Acertar em termos de ritmo. Conseguir um rendimento mais leve, mais claro do Odilon, e ensinar talvez ele a pegar algumas piadas que ele deixava cair. Mas o Hélio conduzia a cena muito bem.

Masetti - Aquela ideia...

Peixoto - A cena, ainda acho ela meio longa. Acho ela meio longa ainda.

Masetti - Longa. E ao mesmo tempo ela... Não sei, a gente sempre pensou em fazer uma cena desligada de... Como se fosse realmente uma esquete de televisão, não é? Onde a única...

Peixoto - É, Teatro de Revista mais ou menos não é?

Masetti - É. Onde a única...

Peixoto - Nesse sentido eu acho que tinha que esculhambar mais, que o espetáculo inteiro estava um pouco bem comportado. Ele estava precisando de um desbunde maior, sabe?

Masetti - Exatamente. Exatamente. Agora, nessa cena especificamente eu acho que a única coisa realmente importante que devia passar era realmente “o que fazer com Calabar”.

Peixoto - “O que fazer com Calabar”, exato.

Masetti - Essa seria a ideia principal, depois o resto era...

Peixoto - Era em cima dessa ideia que tinha que se brincar.

Masetti - ... a briga entre os dois né?

Peixoto -É. Porque a cena era crítica por si mesmo. Quer dizer: o fato de ser uma reunião de estadistas e chefes de estado discutindo a paz sentados na latrina, pô, já diz 
tudo o que se quer dizer. Em cima disso tinha que criar ritmo, vivacidade, e passar a ideia justamente de que... enquanto se caga está se decidindo a sorte do cara. Era a forma de ligar. O que implicava traições, os movimentos da traição dentro da cena que eram muito claros. Inclusive a falta de compromisso ideológico dos dois caras. Agora, eu não sei, essa cena também é uma cena talvez em que uma certa movimentação de fundo pudesse existir. Se a gente criasse uma movimentação permanente de povo. Era uma cena em que eu também gostaria de ver soldados no fundo, mas muito no fundo, sabe? Talvez soldados se mexendo, gente preparando armas, ou comendo. Seria bonito gente comendo também. Enquanto eles cagam. É uma ideia. Não sei. Depois tinha...

Masetti - De certa forma a cena também tinha um caráter de apresentação das duas personagens, não é?

Peixoto - Exato.

Masetti - E aquela jogada do final da cena onde o Chico e o Ruy puseram Otelo do Shakespeare, não é? Apresentando como nós verdadeiramente somos.

Peixoto - É. Eu acho inclusive que essa quebra era bonita.

Masetti - É, exatamente.

Peixoto - Agora, a invasão. A invasão acho que está bem resolvida. Um problema de resolver (talvez com mais detalhes no espaço) certo tipo de movimentação. Acho que passava a ideia da invasão. Talvez nela faltasse um pouco de sangue, de violência.

Masetti- Exatamente. Ela estava mais pro porre do que pra violência.

Peixoto - Mais pro porre do que pra violência.

Masetti - Mais para comemoração do que pra...

Peixoto - Comemoração de vitória do que para aportar aqui. Talvez precisasse de mais detalhes violentos e menos do sexo e de porre.

Masetti - Exatamente. Eu achava que a cena tinha que ter uma puta violência para contrapor com o Hélio Ary que fazia aquela... brincava em cima disso.

Peixoto - De calça na mão.

Masetti - De calça na mão arrumando...

Peixoto - A invasão feita com um cara que está levantando da privada e correndo de espada e calça na mão!

Masetti - Exato. Mas de certa forma eu acho que deu esse clima.

Peixoto - Deu.

Masetti - Deu um pouco isso. Podia se aprofundar muito mais. 
Peixoto - Eu acho que nunca ficou muito clara a jogada do Souto, e eu não sei por quê. Todo aquele jogo de "traidor é isso", "traidor é quem trai isso", a relativização da traição surgia pela primeira vez aí. Inclusive isso foi definido com sutilezas históricas. Eu acho que aí, não sei: tinha qualquer coisa que não ficou clara. Mas a marcação era bonita, o negócio dos dois heróis dormindo, depois os três heróis se unindo na frente. A Anna deitada na mesa. E acho que o tipo de movimentação que se conseguiu com o Frei e com o Hélio definia a cena bem. A fala do Hélio estava bem resolvida, sobretudo por causa do auxílio da música do Edu, inclusive, que fez o fado virar uma música de tourada espanhola. Mas também nessa fala eu acho que o Hélio podia ter sido trabalhado mais adiante. Poderia render mais.

Masetti - Também, também, muito mais.

Peixoto - Poderia render mais. Bom, a entrada da Anna, essa cena, essa dança era meio por fora, não é?

Masetti - Também sentia.

Peixoto - A dança era um pouco um apêndice da coisa. Enquanto ela cantava eu achava bacana porque ela cantava bem pra burro. Mas não sei... A dança era meio gratuita. Embora muito bonita, e ela fazia muito bem, sobretudo na Vieira Souto. Ela perdeu um pouco no João Caetano.

Masetti- O que eu acho é que perdeu o caráter da Anna se apresentando.

Peixoto - É. O relacionamento, o comportamento da Anna frente ao Mathias ficaram meio... [falas sobrepostas].

Masetti - A primeira ideia, com o Edu...

Peixoto - Estava resolvendo num número muito simplista.

Masetti - Exatamente. Era uma coisa bem largadona, bem pianinho mesmo, lá atrás.

Peixoto - Piano de cabaré alemão.

Masetti - Cabaré alemão e ela se apresentando para a plateia, ao mesmo tempo contrapondo o Nassau na base do “e daí?”.

Peixoto - Mathias. Mathias.

Masetti - Mathias. Se você é dono de Portugal, Porto Calvo... E ela dizendo: "E daí?! Sou Anna de Amsterdã”. Acho que perdeu um pouco esse caráter.

Peixoto - Mas ela se apresentava bem. Quer dizer, como continuidade do personagem dela era bonito, da cena da orgia para essa. Agora, a primeira cena do Mathias com o Frei, essa cena que é interrompida pela arraia miúda, aqui acho que nunca se achou 
exatamente o humor dessa cena, não sei por quê. Se é um problema do texto, ou se a gente não achou exatamente a ação do Frei e do Mathias. O Mathias acho que encontrava, ele queria saber os nomes. Agora, o Frei eu não sei. A cena me dava a sensação de não passar para o nível do humor que ela tem no texto, e que ela podia render. E inclusive essa cena a gente grilhou (sic) - quer dizer, a gente não, eles. A gente fez de várias maneiras, apelou para recursos, por exemplo, como o de baixar e subir o capuz. O Frei sem capuz. Aquela ideia era bacana, eu achava a ideia bonita.

Masetti - Acho que tem uma coisa do humor na interpretação do Lutero.

Peixoto - É. Eu não sei se ele não se jogava inteiro, ou se havia também uma preocupação de fazer essa cena muito a sério. A seriedade que tem na cena...

Masetti - A seriedade do tema da cena. O Lutero, principalmente, assimilou isso - como se o texto sério devesse exigir uma interpretação muito séria. Quando eu acho que devia contrapor.

Peixoto - Exato. Agora, essa cena é cortada, em uma interrupção das mais difíceis de fazer do espetáculo, mas que eu acho que estava funcionando apesar de tudo.

Masetti - Funcionou. Com a luz funcionaria.

Peixoto - Com a luz funcionaria. Com a arraia miúda. Eu acho que, no final, essa cena da arraia miúda estava saindo até bastante bem.

Masetti - Estava. E a ideia é boa.

Peixoto - E a ideia é boa. Sobretudo a movimentação do coro no nível da transformação daquela primeira cena... Os caras agora estavam agrupados, mas cada um no seu instrumento de trabalho. E cantando Miserere numa forma meio carola. E com aquela gesticulação meio biomecanista, sei lá o que era aquilo. Uma gesticulação mais abstrata, onde os gestos que eles faziam quando eles trabalhavam se transformavam em gestos abstratos. Mais coletivos. Era bonito o momento em que a Bárbara saía do meio deles. Tinha pequenos grilhinhos (sic) aí, que eu acho que era uma interpretação muito simples. A volta do Frei com o Mathias acho que poderia ter tirado mais. Acho que funcionava muito bem a continuação da cena anterior, faltava talvez exagerar o subtexto de 1973. Sabe? Nas falas do Mathias. Que o Lutero encontrou uma pulga, uma forma de se comportar na cena.

Eu acho que o Hélio não levou tão longe o que ele podia fazer no nível de criticar o personagem, mesmo, aí. Um pouco porque ele estava preocupado, e a gente também não chegou a uma alternativa muito clara, sobre até que ponto confissão de Mathias era 
muito séria e deveria ser representada como um ato sério; ou como um ato cômico. Eu acho que eles poderiam talvez ter feito um pouco mais de fora o personagem, nesse sentido, engravidando ele mais de 1973. Entende?

Masetti- Uma série de valores...

Peixoto - Se bem que “O que é bom para o Portugal é bom para o Brasil” sempre funcionou com público.

Masetti - Sempre.

Peixoto - Mas acho que o tom da cena estava naquele momento em que o Hélio dizia: “Eu tenho pensado neste meu país”. E o Frei dizia: “Que Deus lhe perdoe”.

Masetti - "Que Deus lhe perdoe”, exato.

Peixoto - Acho que ali batia o tom da cena. Bom, em seguida a cena da morte do Calabar. Também faltou luz, faltou mil coisas para a gente fazer. Inclusive a morte de Calabar a gente nunca fez. Com o garrote, nunca foi feito. A Tatuagem a Tetê cantava muito bem, era bonita a ideia. Faltava botar o Afonso nu e com sangue, e tudo isso. Mas era bonito.

A sentença eu acho que ficava um certo buraco. Aqui eu tinha dúvidas. Se seria o caso de deixar o meu texto mesmo lido, quer dizer, gravado por mim. Se aquilo ressoasse no teatro inteiro... Faltou mixar com a bateria. A bateria ao vivo e aquilo gravado: teria de ver em cena. $\mathrm{O}$ fato de ficar vazio o palco enquanto acontecia aquilo achava bonito, não sei. Com a Tetê olhando a figura dele, dava uma espécie de pausa no espetáculo.

E aí começava a cena que eu achava das mais bonitas do espetáculo, que era a dos três heróis. Acho que a marcação geométrica que se encontrou na cena - aquele triângulo, e o fato de a cena ser mantida num nível nada realista, como movimentação, ser mantida dentro daquele desenho geométrico da cena, do triângulo, e o fato de deixar como único elemento móvel na cena a Bárbara interrogando - dava todo o dinamismo na cena. Além do fato de que os três atores passavam exatamente as ideias. Essa é uma cena que eu achava bastante bem realizada.

Masetti- É, a ideia de lavagem de mãos, realmente, dos três macaquinhos.

Peixoto - Inclusive o final dos três macaquinhos eu acho que funcionava.

Masetti - Também.

Peixoto - O Flávio no final conseguiu uma forma já bem mais relaxada de fazer a fala final dele. O texto final: “Não sei, só sei que sempre fiz o que era pra ser feito”. E aí vinha a morte do Calabar que nunca foi feita. 
Agora a primeira cena da Bárbara e Anna. Eu não sei, eu acho que faltava um pouco de ritmo na Betty, uma certa vivacidade uma hora, sobretudo nas primeiras falas. Agora, eu achava a cena bonita com marcação também, as atrizes saíam muito bonito.

A Anna é um personagem estranho, é um personagem que chega não se sabe de onde. É difícil a Anna entrar nessa cena. O início do relacionamento da Anna com a Bárbara não é preparado. Então a cena é muito... Ela começa e termina nela mesma, é muito estranha. É uma cena difícil de ser feita, mas acho que ela estava sendo resolvida. Agora uma coisa bacana que a gente deixou de lado, e pudesse gravar também, é o "Ninguém sabe nada, ninguém viu nada”. Aquele momento eu achava bonito. Era justamente bonito porque era cantado parado. Porque a letra passava... O gesto estava encontrado. Em muitos momentos a gente não trabalhou bem o gesto das músicas. Talvez até por uma certa dificuldade de diálogo com o próprio Dori nesse sentido, e com o próprio elenco. Mas acho que aí o gesto estava absolutamente encontrado. Como Tatuagem também estava.

E a canção de Bárbara acho que ia bem. Você tem algo a dizer desse final da primeira parte?

Masetti - Não. Tranquilo. Eu acho que na primeira parte, de certa forma, um problema é que os personagens não tem muita continuidade, entende? Ele apresenta, e sai, e vem entrar depois de duas cenas. Para o espectador é meio difícil, eu sentia meio difícil de conseguir relembrar as características desse personagem. Acho que isso talvez tenha prejudicado um pouco. Mas de toda forma acho que está...

Peixoto - Agora se tem a transformação inteira do cenário com a entrada de Nassau. A entrada das bandeiras, da cor, o carro que entrava do fundo. Que antes não era visto. Eu achava bonita a entrada da corte.

Masetti - Muito bonita.

Peixoto - E aí entrava o povo. Aqui sim, aqui eu achava bacana. Era meio Debret o povo entrando e começando a caminhar, aquela espécie de praça pública, eu acho que dava um retrato do país. Eu não sei se eu não devia ter trabalhado o povo no sentido da guerra. Nas cenas anteriores, do acampamento.

Masetti - Exato.

Peixoto - Faltava gente também, na realidade teria de fazer com o dobro. Essa cena eu acho que era bonita porque preenchia, enchia o palco inteiro. E a chegada do Nassau, da corte, acho que isso funcionava muito bem. O hino holandês funcionava muito bem. E 
geralmente até o final do primeiro ato, quer dizer: a explosão do frevo que era muito gostosa. Inclusive a Betty cantava muito bem o frevo. Com um pouquinho de falta de voz, mas faltava também o apoio de microfone para ela. Mas ela cantava muito bem. Eu achava legal. Eu acho que essa primeira parte funcionava mais com público do que a segunda, em geral. Ou seja, até o frevo.

Masetti - Exato.

Peixoto - Até o primeiro frevo, até onde a gente decidiu terminar o primeiro ato. Eu não sei bem por quê. Porque era tudo fraccionado até aqui, não é? A linguagem do espetáculo, era tudo: uma cena é uma cena, outra cena é outra cena. É uma espécie de montagem de cenas. Mas tinha uma vivacidade que interessava, até aí. A segunda parte do espetáculo é que tinha alguns problemas. Talvez inclusive porque as cenas finais não foram muito trabalhadas, faltava mais ensaio para as cenas finais. Mas sei lá. Desse primeiro ato, você tem coisas para dizer?

Masetti- A única coisa que atribuo realmente é essa... As cenas serem muito fraccionadas, existir uma falta de elementos de ligação.

Peixoto - É. E eu acho que a gente não trabalhou o povo no nível militar. No nível dos acampamentos. Quer dizer, trabalhou sim, indicou muito bem, inclusive abria muito bem. Mas isso não preencheu certas cenas, como a do fado, a das latrinas. A do acampamento holandês, que não se sentia o acampamento holandês. Se bem que passava a ideia de uma... Um pouco por causa da orgia que era muito forte, não é?

Eu achava bonito o intervalo da forma que foi feita. Eu não gosto de intervalo, mas achava bonito. Quando entrava o frevo de novo, e o povo entrava, invadia o palco, os atores invadiam o palco para cantar o frevo. Aí o que tinha?

Masetti - As impressões do Recife.

Peixoto - Impressões do Recife, isso tudo ia muito bem. Tinha uns probleminhas de ritmo, mas a ideia Nassau - Chacrinha - Juscelino demagogo, tudo isso passava. Funcionava muito bem. Até o frevo das bichas, que era brilhante.

Masetti - E as primeiras intervenções do agente.

Peixoto - Do agente. Que inclusive funcionava com público, engraçado.

Masetti - Exatamente, e com público foi realmente uma surpresa.

Peixoto - Foi uma surpresa. E o nível de coreografia era bonito também. Do frevo feito pelas bichas. Aquela ideia de prolongar a piada da capital da pederastia. Aí tinha a primeira cena com o engenheiro, o “Oba”. Eu gostava do “Oba” pra porra. O 
engenheiro, aqui fundamentalmente quem mandava era o Ganzarolli, eu acho que era a coisa mais forte da segunda parte. A firmeza, a precisão, a exatidão, o rigor com que ele executava cada gesto, cada pensamento. Ele passava... talvez houvesse às vezes até um certo excesso de rigor.

Masetti - Exato. Principalmente nesse começo.

Peixoto - Talvez tinha de se dosar um pouco isso. Mas era um ator de uma precisão inacreditável, e era um personagem que representava o público. Era uma interpretação épica realmente, das mais bem conseguidas do espetáculo inteiro. Essa cena acho que funcionava bem, inclusive o Lutero fazia muito bem a movimentação do Frei dentro do novo esquema governamental.

Masetti - Exatamente.

Peixoto - A aproximação dele e do Nassau, acho que tudo passava muito bem. Depois vinha a primeira cena. Ah, tinha o ... O escrivão também era bacana. Acho que o pintor não se resolveu muito bem, e o astrônomo também não resultava muito não. Mas funcionava. Depois tem a primeira cena da Bárbara e do Souto. Aqui acho que o maior problema realmente foi a dificuldade de entrega da Tetê na cena. A cena se... ela tinha altos e baixos.

Masetti - Exato.

Peixoto - A entrada da cena já era duvidosa, a forma de eles entrarem correndo com aquele samba atrás. Depois a inclusão do sambão, do "holandês chegou”, nunca foi incorporada pelo Flávio direito.

Masetti - Eu atribuo aí também a um problema do texto, em que preparam para atacar a Bahia e existe um pulo, entende?

Peixoto - É, muito grande.

Masetti - De uma cena para outra a Bahia já foi atacada. E realmente o Souto, o Flávio tinha que entrar com a responsabilidade de contar a derrota dos holandeses na Bahia. Entende? O que eu acho é que pra ele era muito difícil.

Peixoto - É. E ele não conseguiu incorporar muito bem a música. O sambão, no texto dele.

Masetti - Exatamente.

Peixoto - O Você vai me seguir nunca saiu direito porque ele não sabia de cor, a música chegou no final.

Masetti- O que eu acho também é que, toda a parte política, entende? 
Peixoto - Da cena?

Masetti - As falas políticas, entende?

Peixoto - Eu acho que essa cena não ganhou a grandiosidade que ela teria de ter no espetáculo. Sabe?

Masetti - Exatamente.

Peixoto - Aquilo que eu falei no último dia: “É uma cena que precisaria ser feita entre um rei e uma rainha”. Não entre as personagens. Ela tinha uma grandeza shakespeariana, essa cena, que ela não foi atingida nunca. Por falta de uma entrega maior da Tetê talvez - se bem que às vezes era maravilhoso quando ela fazia. Era genial. Mas ela não tinha uma continuidade clara. A cena estava muito bem esmiuçada, muito bem estudada, mas a cena não se realizava inteira. Eu acho que a cena estava ali, mas não tinha explodido ainda. Talvez com mais ensaio, uma colocação mais clara dos problemas, ela explodisse. Eu achava bonito certo comportamento de Souto, também, aqueles pulos, a coisa meio estilizada, meio teatralizada que ele fazia. Enfim, essa cena não abriu para o público com a intensidade que ela poderia abrir, eu acho.

Masetti - Exato.

Peixoto - Depois vinha o Tira as mãos de mim que era, sobretudo o final, a parte final da Bárbara, a parte política mesmo da cena...

Masetti - Exatamente.

Peixoto - O Tira as mãos de mim eu achava bacana pra burro. Inclusive como solução coreográfica, a parte do saxofone meio Gershwin, aquele negócio de pegar vários momentos, e vários gestos...

Masetti - Dos dois atores.

Peixoto - Dos dois atores e fazer deles o gestus da música. E a música era das coisas mais bonitas da peça. Depois vinha a missa, não é?

Masetti - Isso. Vem a Restauração.

Peixoto - A Restauração, tem a imagem aí do pulo violento...

Masetti - Tem um pulo violentíssimo.

Peixoto - ...de época. Se bem que eu acho que aquele recurso que eu usei de fazer o pessoal repetir rezando a partir do “Oremos” até o “del Gracias”... Eles rezando: “Dom João IV, Dom João IV, está sendo aclamado, está sendo aclamado”... levavam a uma definição, tentavam explicar a cena numa história. O texto do Nassau eu achava longo. 
Essas intervenções do Nassau junto com a missa. Essa missa será que funcionava? Eu acho que funcionava, pela reação da plateia.

Masetti - O negócio de abaixar...

Peixoto - Não, o negócio de, no nível de acabar com uma cerimônia religiosa e transformar em uma coisa inteiramente profana, sacrílega.

Masetti - Ah, isso estava claro.

Peixoto - Acho que isso estava claro.

Masetti- Agora, o que não estava claro era... Estava clara a ideia de transformar uma coisa sacra em profana. Mas não estava claro o porquê. Eu atribuo isso a um problema de texto também. O problema da Restauração que não ficou clarificado o suficiente. Agora, visualmente eu acho que era uma das cenas mais bonitas.

Peixoto - E o engenheiro... Bom, depois era a ponte, era a continuação da cena, e entra o boi voador. Até a inauguração. Esse texto de Nassau eu ia cortar um pouco.

Masetti - É. Isso eu acho.

Peixoto - Aí vem o boi voador. O boi voador tranquilo, era gostoso, o boi voava bonito pra caralho. A ponte, o boi: aí acho que não tinha problema nenhum. Eu não sei se... Mas isso é meio inevitável, nesse tipo de musical. O texto não propõe outra coisa. O povo meio se perdia, ficava meio coreografia. Eu gostava quando o povo, depois do boi voador, ficava estático em cima da ponte. Que a partir daí eu acho que com a luz a gente ia criar um painel dos caras em cima da ponte.

Masetti - Exatamente.

Peixoto - E as cenas mais íntimas que vêm depois, acontecendo na frente daquele povo. Então as cenas perderiam um pouco a intimidade que elas têm, e ganhariam uma outra dimensão, porque elas seriam lidas pelo espectador através da presença do povo parado na ponte.

Masetti - Exato. Uma coisa talvez tenha prejudicado também, eu acho que era uma coisa praticamente impossível de conseguir da Tetê principalmente. Dos atores, quer dizer. Que nessa cena Bárbara e Anna ficavam na missa, entende?

Peixoto - É, isso eu ia tentar no final colocar, mas... A gente não ensaiou essa parte, não chegou a ligar isso.

Masetti - Realmente era difícil... Exato. 
Peixoto - Então tinha a cena do Nassau com o agente holandês. Que é bem maravilhoso o que o Ganzarolli fazia, e o Hélio estava muito bem. Eu acho que essa cena esclarecia. A cena seguinte o que era?

Masetti - Acho que o boi, não é? Não, já foi.

Peixoto - Ah, mais uma cena do Souto e Bárbara.

Masetti - Exatamente.

Peixoto - O importante ali era a definição do Souto, isso eu acho que estava claro. O Souto se definindo, assumindo Calabar, e levando-o à loucura. Acho que estava claro. Essa continuidade, no nível do desenvolvimento psicológico mesmo do personagem, e esse clima neurótico da cena, acho que isso vinha, entende? Precisava de mais ritmo, também, precisava ganhar uma força maior, mais shakespeariana também a coisa, mas acho que vinha. Essa cena ia bem. E sobretudo com a cela que faltou, era um elemento tão importante para os ensaios...

Masetti - Exatamente, tudo apoiado em cima dela...

Peixoto - Ele entrar com a cela, ela ficar junto à cela...

Masetti - A ideia do cara que não tinha casa, não é?

Peixoto - Não tinha casa, carregava o próprio cavalo...

Masetti - A primeira fala da cena era: “Casa, que casa?”.

Peixoto - A morte dele eu achava bonita, muito bonita. A ideia de fazer aquela coisa do Coriolano de pegar as espadas, eles se encararem com as espadas, de repente largarem as espadas e fazerem sem armas a morte. Como se estivesse fincando punhais, ou espadas. Mas usar mesmo: já que não podes fincar uma espada num ator, então faz sem a arma. Joga as armas fora e faz com o gesto, só.

Masetti - Exato.

Peixoto - Isso eu achava muito bonito. E a ideia da morte como tourada. Como um touro que ficava levando bandarilha nas costas.

Masetti - Os dois soldados, não é?

Peixoto - Isso eu achava bonito. Os soldados se cruzando. Como eu achava muito bonito, também, o momento em que ele caía morto e se levantava para dizer: “Aqui eu fico”. E falava aquela cena para o público.

Masetti - Exatamente. 
Peixoto - Tinha um problema que não se resolveu direito. Era o momento em que ele caía morto, e que ele tinha que sair vivo - o ator sair de cena. No Vence na vida quem diz sim.

Masetti - Tinha a ideia de o ator mesmo sair de cena.

Peixoto - O ator sair de cena. Isso não foi trabalhado.

Masetti - Agora, como ideia eu acho que...

Peixoto - A cena seguinte da Bárbara e da Anna. Acho que o problema era: o Vence na vida quem diz sim nunca atingiu o significado ideológico dele. O cinismo e a ironia dele.

Masetti - Exato.

Peixoto - Faltava um pouco de ritmo e de coisa popular na Betty. Estava ali; era só um “empurrão” que tinha que dar nela para ela pegar mais força na cena com a Bárbara. Mas era legal. Acho que isso ia bem. A cena da paramentação não foi muito curtida por nós. Foi feita muito rápido. A paramentação podia ter toda uma coisa mais teatral. De maquiar a cara...

Masetti - Exatamente.

Peixoto - Eu ia fazer...

Masetti - Primeiro ia fazer em cima do carro, não é? Ia fazer em cima do carro, tinha que ser uma cena bem destacada, como uma paramentação mesmo.

Peixoto - É.

Masetti - Quase que ...

Peixoto - Eu acho que o teatral da cena não foi explorado até o fim. E era muito teatral a cena. Uma cena pouco trabalhada mesmo.

Masetti - E também, muita dificuldade de interpretação. De se conseguir um rendimento maior dos atores.

Peixoto - E se ensaiou pouco essa cena também. Por dificuldades também dos atores. Depois vinha a cena paralela, quer dizer, a Bárbara tinha que sair muito maquiada, muito transformada. Bonita, mas estranha - uma coisa meio Jean Genet.

Masetti - Exatamente.

Peixoto - Para entrar e esbarrar com o Frei. Aquela cena do Frei, eu tenho a impressão de que no último dia eu cheguei a... O dia em que não houve ensaio. No último ensaio, que não aconteceu, eu cheguei a conversar com os dois antes. Eu tenho a impressão de que ela ia ganhar um dinamismo maior. Que essa cena teria que ser mais ou menos 
como a cena do... Eu achava bonito (mais uma vez) o geométrico da cena paralela. Quer dizer, o Ganzarolli e o Hélio lá em cima do plano mais elevado, e o Frei e a Barbara diante daquela tela branca do lado esquerdo do público. Agora, essa cena nunca ganhou o dinamismo dela direito. Mas ela podia, isso era uma coisa simples. Eu acho que a cena estava bem encaminhada. Inclusive a cena tinha uma empostação não realista, também, como movimentação. Eu achava bonito. Então ia para o Cobra de Vidro. Cobra de Vidro acho tranquilo, a marcação é perfeita. A ideia de A Mãe, do Gorki, do Berliner Ensemble.

Masetti - E a arraia-miúda subindo...

Peixoto - Uma coisa: o pano que ficava nela tinha que ser vermelho. Ia dar um sentido político muito grande se ela estivesse com um pano vermelho na mão, era exatamente a bandeira vermelha de A Mãe, do Gorki.

Masetti - Exatamente.

Peixoto - Com a arraia-miúda então vindo de lá, que já veio no Vence na vida. A arraiamiúda não: o povo inteiro vindo, e unido naquele paredão. Aquela coisa de passeata avançando em cima do Cobra de vidro. Depois, a cena final: eu achava muito legal a colocação do Ganzarolli também, ficava muito claro o sentido... A contradição do Nassau entre homem de letras e militar.

Masetti - Eu acho que aquela cena podia ser mais engraçada.

Peixoto - Podia, podia.

Masetti - Eu acho que ela devia ter um desbunde muito engraçado.

Peixoto - Um desbunde maior também, exatamente.

Masetti - Porque ela vem logo em seguida ao Cobra de Vidro, que foi montado como se fosse uma coisa muito violenta.

Peixoto - Que é o final, mesmo. O grande final da peça.

Masetti - Seria o final da peça mesmo.

Peixoto - E no final, ainda, eu achava muito bonito quando se fechava o povo todo, de costas, junto ao carro de Nassau. E ficavam de frente o Frei, o Agente holandês, os dois soldados holandeses, enfim: continuava a dominação holandesa. Com aquele hino tocando, para então chegar a Bárbara, interromper o hino como atriz e dar o recado final.

Masetti - Exatamente. 
Peixoto - E aí vinha o desbunde final da canção O que é bom pra Holanda é bom pro Brasil. Que era legal.

Masetti - Que era muito, muito bom.

Peixoto - Mas tinha que se acabar o espetáculo antes. Nunca se deu esse efeito, com a falta de luz, nunca se deu esse efeito também. Aí tinha que ser um desbunde total, como no final da semana. E mais irônico, mais cínico. Eu acho que faltava isso, às vezes, no coro: o cinismo, a ironia, a inteligência cínica.

Masetti - Exatamente.

Peixoto - Mas sei lá, não sei.

Masetti - Sei lá, de um modo geral eu acho que essa segunda parte pecou pela... não foi muito trabalhada. Faltou ganhar o ritmo e a alegria. A parte mais colorida mesmo, eu acho. Tem três cenas muito compridas de dois atores só. Souto e Bárbara, Anna e Bárbara...

Peixoto - Sobretudo aquele Anna e Bárbara entrava na estrutura de uma forma muito estranha. Interrompia demais. A presença talvez dos caras atrás também se demorasse demais, mas eu acho que é porque as cenas da frente não estavam bem resolvidas. A presença do pessoal na ponte, estático.

Masetti - Exatamente.

Peixoto - E com luz também, eu acho que ia ganhar outra dimensão. O que mais senti mesmo foi... Aquela ideia original que se tinha, de enxertar as cenas com o trabalho. Fazer essa história acontecer toda com o povo trabalhando e vivendo. Isso estava esboçado, e havia muitas cenas que se realizavam, mas não se realizava no total. E eu não sei, faltou tanta coisa para poder acabar que agora está me parecendo... eu estou achando desculpa para tudo. Me parece que a gente ia chegar lá com mais tempo de trabalho, e com condições de trabalho.

Masetti - Ah sim, sim. Tranquilamente.

Peixoto - E tinham alguns problemas de estrutura da própria peça, que tinham de ser resolvidos. Talvez com alguns cortes. Acelerar. Todo o ritmo da peça devia ser mais acelerado, inclusive por causa do musical.

Masetti - Exatamente. Claro.

Peixoto - Embora a música não tivesse um sentido crítico permanente, muitas músicas tinham esse sentido. 
Masetti - Claro, isso poderia se dar. Inclusive o trabalho de interpretação também era difícil. Porque muitos atores... é um defeito, acho, de teatro brasileiro, o ator interpretar psicologicamente. Entende? Num musical, numa peça que é despojada. Não dá tempo de você ter um olhar psicológico...

Peixoto - Como conduzir o ator também, levar a isso direito.

Masetti - Exatamente.

Peixoto - Quando você encontra um ator como o Ganzarolli, que realiza o personagem de fora. Ou como o Flávio, que em determinados momentos conseguia muito bem, ou o Hélio Ary. Mas com outro tipo de ator, que ainda acredita numa verdade, numa emoção, numa identificação com o personagem, você dificilmente tem tempo de conseguir trabalhar o cara e explicar para ele as verdadeiras razões do que você está querendo. Então isso deixa o trabalho meio pela metade. Aconteceu isso no Frank V, por exemplo. Poderia talvez se obter resultados melhores nesse sentido. Não sei, eu acho que faltou no final um pouco de força psicológica, mesmo, para levar o espetáculo até o fim. Embora tenha aguentado a barra. (Corte final na gravação). 


\section{ANEXO F}

\section{Depoimento de Fernando Peixoto sobre Calabar - 18 de novembro de 1973}

(Transcrição de fita cassete localizada no Arquivo Fernando Peixoto - CEDOC Funarte).

Sei lá. Deve-se fazer uma espécie de tentativa de reflexão sobre o Calabar, agora que o espetáculo terminou. Eu não sei se exatamente a montagem de Calabar não significou para mim, talvez inclusive por ter sido uma montagem abortada, pelo fato de que o espetáculo não vai ser encenado, pelo menos da forma que foi ensaiado... se ele for remontado, certamente vai ser modificado.

Eu não sei até que ponto essa montagem, feita evidentemente às pressas, pouco tempo de ensaio, uma montagem bastante complexa, na medida em que implicava a utilização de coreografia, de música, o trabalho com uma equipe de qualidade, mas ao mesmo tempo não totalmente identificada até o fim numa mesma visão das coisas. Talvez a equipe que produziu o espetáculo não tenha pesquisado entre si, discutido entre si até suas últimas consequências o verdadeiro significado da montagem Calabar como obra de arte.

Sinto uma certa crise diante do que eu penso que seria o espetáculo. Eu sinto mesmo que nos últimos ensaios ainda não me satisfazia. Talvez nem tanto por resultados que eu pretendia alcançar, e não atingia, mas porque a própria proposta talvez me colocasse em uma certa crise. Eu tenho a impressão de que Calabar poderia, talvez (eu não sei se isso é verdade), encerrar um processo de trabalho. Ou melhor, nem encerrar, mas talvez fosse o momento de dar agora um salto qualitativo, no nível de um aprofundamento do significado do teatro. Em certo sentido, montando Calabar dentro de circunstâncias muito difíceis e particulares, e preso a toda uma série de ingerências de ordem institucional e profissional (em certo sentido da palavra), eu estivesse necessitando agora de um trabalho experimental. De partir para uma pesquisa da linguagem teatral em um outro nível.

Quando falo “outro” eu não quero dizer “outro”: eu quero dizer aprofundar o já existente. Acho que o caminho está certo, acho que a proposta - sobretudo política para mim ainda é essencial. Mas vendo um espetáculo como o do Kerensky ontem, os dois espetáculos que eu vi ontem, eu sinto que dentro de uma certa liberdade de 
trabalho, de um trabalho mais liberto de uma série de problemas de um espetáculo profissional, uma superprodução... a presença do dinheiro por trás traz uma certa limitação.

Ou seja: talvez a vontade de fazer um trabalho que não dependesse da bilheteria (bilheteria sim), dos gastos, dos horários, das datas, dos limites de tempo de ensaio, do grande número de pessoas reunidas. Eu não sei que tipo de trabalho seria esse. Que tipo de aprofundamento na teatralidade teria de ser buscado. Não é evidentemente o que é desenvolvido pelo Kerensky. Não é um trabalho grotowskiano que me interessaria. Mas existe no espetáculo dele uma certa... o peso do silêncio, o peso do movimento, o peso da entrega do ator. Eu não digo a entrega no nível da identificação com o espectador, no espetáculo Dysangelium, por exemplo, não existe essa identificação. Existe a execução do ator de uma série de ações teatrais, realmente.

Sinto que a cena deveria ter sido trabalhada num nível de aprofundamento maior. Eu tinha pela frente um texto muito compacto, na verdade, e muito literário. Em muitos casos dispersivamente literário, ou seja, um excesso de palavreado. Um excesso de diálogos. Por outro lado, as cenas da peça enquanto texto talvez não fossem propriamente curtidas. Ou então me deixei levar pela superficialidade proposta pelas palavras, sem uma pesquisa maior do que havia por trás delas. Eu nem sempre consegui, talvez, aprofundar o relacionamento entre as cenas e a realidade, coisa que me preocupa. Até que ponto a realidade do país, realidade na qual eu estou inserido, até que ponto os meus problemas pessoais dentro dessa realidade não teriam que ser confrontados com o texto num nível de maior profundidade. Essa é uma pergunta que eu me faço. Até que ponto a solução das cenas, embora teatralmente vivas, visualmente claras, não esbarravam em um limite de uma ilustração do texto. Até que ponto muitas soluções não teriam sido encontradas dentro de uma rapidez que é inimiga de um aprofundamento maior. Até que ponto não teria sido necessário apanhar momento por momento do espetáculo, e discutir todas as suas alternativas; pesquisar dentro dessas alternativas a que seria a mais justa de ser colocada para o público. Até que ponto a pressa em formalizar uma solução final para o espetáculo não teria resultado em uma simplificação, um esquematismo de muitos momentos. Até que ponto esse esquematismo obedecia, não a uma vontade de ser esquemático no sentido de ser claro ou popular, mas obedecia a um impulso imediato de criação não curtido em suas últimas 
consequências por mim mesmo e por toda a equipe de trabalho. São alguns problemas que estão me batendo agora.

Até que ponto o próprio estudo do espetáculo, embora tenha sido feito com todo o cuidado, com toda a minuciosidade, não se deteve em soluções fáceis. E não repetiu, embora num nível de criatividade pessoal e de certa eficácia, não refletiu pura e simplesmente uma depuração de formas convencionais da teatralidade. Eu acho que em muitos momentos deveria ter sido pesquisado um outro processo de teatralidade, uma outra qualidade teatral. Que terminaria por revelar uma outra qualidade do significado do homem, e um outro aprofundamento em um nível do relacionamento entre os homens, e um outro aprofundamento no nível de como apresentar, diante de um público, uma determinada situação onde as pessoas se comportam umas em relação às outras.

Não sei até que ponto o espetáculo traduzia o verdadeiro significado do texto. Que eu sempre defini como uma reflexão sobre a traição. Até que ponto a reflexão sobre a traição devia ter sido levada às últimas consequências, no nível de refletir sobre o que eu traía como encenador realizando o espetáculo. O que eu traía por omissão, ou por cair no convencional.

Escapando à possibilidade de uma autocrítica, saber realmente - talvez pelo espetáculo não ter sido realizado até o fim - até que ponto, no fim das contas, esse espetáculo (assim como outros que eu já realizei) não se deteria em um limite de uma lógica e de um didatismo, que eu considero fundamentais, porém simplificados. Até que ponto seria possível um aprofundamento maior. Realizar um teatro político, didático, histórico, mas que aprofundasse mais todas as colocações. A palavra aprofundar está vindo demais em tudo o que eu falo, talvez como um reflexo de eu estar sentindo que em outros campos totalmente diferentes dos meus, totalmente opostos às minhas propostas, um aprofundamento pode ser realizado. Eu não digo isso do teatro convencional, profissional, feito no país. Diante desses, Calabar era um espetáculo de extremo significado.

Mas o espetáculo de Kerensky, embora profundamente desvinculado das minhas propostas de teatro, me revelou um dado fundamental que me agita. Está me bouleversant por dentro. É que no fundo trata-se de um trabalho realizado, talvez, até as suas últimas consequências. Talvez contando com uma pesquisa de meios impressionais muito mais minuciosa e muito mais rica. Claro que, se eu fosse comparar 
os dois espetáculos, eu acharia Calabar mais importante. Mas será que Calabar não seria mais importante só por ser mais simples?

Ou melhor, é mais importante discutir... será que não seria possível dar a um espetáculo como Calabar um significado mais profundo, como reflexão sobre o momento histórico da peça em sua relação dialética com o momento histórico que estamos vivendo hoje, assim como uma apresentação mais complexa (portanto mais rica, mais reveladora, mais provocativa, mais crítica também) da reflexão sobre o traidor e sobre a traição.

Talvez o sentimento de frustração que eu tenho, eu não sei distinguir até que ponto é de fato pelo espetáculo não ter se completado, o que sempre me deu uma ideia de um espetáculo... bom, o espetáculo foi castrado mesmo. Mas será que, no momento em que foi castrado, ele não poderia já ter atingido um nível maior? E até que ponto, se isso aconteceu (admitindo a hipótese de que o espetáculo não tivesse essa profundidade que me interessaria ter), até que ponto isso se deve a um desleixo meu de trabalho? Ou até que ponto se deve a uma dispersividade pessoal minha em termos de trabalho? Ou até que ponto se deve a uma incapacidade minha de uma pesquisa mais profunda? Ou até que ponto se deve a uma incapacidade minha de pensar com mais profundidade? Ou até que ponto se deve a uma incapacidade de realizar o que eu penso? Ou até que ponto se deve às condições empresariais em que ele foi encenado? Ou até que ponto se deve à presença de milhões de milhares de cruzeiros sendo gastos e às datas limites para ensaio, para apresentação pública? Até que ponto se deve ao fato de eu estar trabalhando com gente conhecida, até que ponto se deve a uma não integração total entre a equipe num nível de uma discussão de princípios? Até que ponto se deve a concessões feitas diante de problemas ou a desistências diante de barreiras? Até que ponto se deve a bloqueios dos outros ou de mim, e à relação dialética que se estabelece entre o grau de libertação dos meus próprios bloqueios, e o grau de libertação dos seus próprios bloqueios dos demais componentes da equipe, tanto atores como equipe técnica, e realizadores, e produtores, e cenógrafos, e músicos, etcetera?

Até que ponto uma certa segurança como encenador, que eu já tenho, me leva a tentar buscar soluções... até que ponto, talvez, a mania de esperar que o cenógrafo contribua, que o músico contribua, que o coreógrafo contribua, me leva a (em vez de desenvolver a minha capacidade de aprofundar) esperar que os outros deem os dados para que eu possa aprofundá-los? E quando esses dados vêm incompletos, ou vêm 
pobres, até que ponto isso não significa uma castração em um nível criativo, que impede de levar o espetáculo, e suas consequências, e sua reflexão, mais longe?

Até que ponto eu também não tenha levado em conta os problemas que o próprio texto oferecia? Algumas cenas foram trabalhadas em um nível mais profundo. Tentaram ser trabalhadas; surgiram também problemas com alguns atores, que resistiam demais. Até que ponto eu deveria ter vencido esses limites? Até que ponto teria sido possível fazer isso?

Até que ponto uma peça como Calabar, cuja reflexão histórica é entremeada de superficialidades, ou cuja reflexão histórica é pouco minuciosa quanto a uma análise marxista dessa realidade... até que ponto isso realmente constitua um freio que eu talvez não tenha sentido em outros espetáculos feitos anteriormente, porque o meu grau de capacidade para a compreensão disso não tenha existido. Talvez também porque eu não tenha repensado espetáculos já feitos dentro dessa perspectiva. Talvez inclusive porque os problemas dos meus outros espetáculos eram de outra ordem, de ordem mais simples também os próprios problemas. O que me levava a pensar mais simplesmente. Agora, talvez porque eu tenha realizado um trabalho mais maduro meu, evidentemente as questões que se colocam para mim mesmo são questões mais graves.

Não sei que resposta dar a esses “até que ponto” todos que estou enumerando. E sobretudo até que ponto, talvez, o fato de não ter concluído o espetáculo, essa frustração de não ter acabado o trabalho, de não ter visto o trabalho... até que ponto talvez isso: espetáculos meus anteriores, em contato com o público, funcionando em relação com o público, sendo compreendidos, sendo aplaudidos, e sendo inclusive criticados (sem grande incidência interpretativa mas pelo menos sendo aceitos pela crítica), não tenham me levado a me deixar satisfeito com o trabalho realizado. E o fato de Calabar não ter sido encenado ter me levado a eu mesmo fazer a reflexão crítica como público e como crítico (vamos dizer assim) diante do próprio trabalho, num nível bem mais exigente.

Enfim, em que ponto de estado atual eu estou pra me lançar em um novo espetáculo. Eu sinto que eu seguiria sempre a mesma proposta. Mas talvez a minha contribuição pessoal com o revisionismo brechtiano teria condições de se realizar, não digo "num nível”, sob hipótese alguma, mas pelo menos "num nível de intensidade e de inquietação” de um trabalho como o de Planchon, por exemplo. Que num espetáculo como Tartufo aprofundava cada segundo do espetáculo em um nível absolutamente fascinante. 
Até que ponto, também, com essas pesquisas feitas com esses grupos jovens, eu não estou esbarrando com outra mentalidade de pensar que está me problematizando, na medida em que está primada em outras coordenadas? Essa semana não só o encontro com outros espetáculos, alguns dos quais minha capacidade crítica se exerceu sem problemas - mas diante do espetáculo do Kerensky a minha capacidade crítica não se exerce sem problemas, porque o espetáculo me toca. Me toca no nível de me colocar problemas. Isso é a coisa mais importante que aconteceu. Até que ponto também a leitura do livro do Maciel, A nova consciência, embora seja um livro que eu li com a maior facilidade, que não me causou nenhum tipo de perplexidade, com seu próprio fascínio pela lucidez com que ele (Maciel) consegue defender ideias que eu absolutamente discordo, mas a capacidade também contraditória que ele tem, de às vezes ser um analista lúcido e quase dialético. Até que ponto esse encontro com toda uma juventude inquieta do momento não deve provocar em mim justamente - e isso seria muito positivo - uma reformulação de uma linguagem teatral que eu estaria realizando? E que estarei sendo talvez o que melhor pode se fazer dentro de uma linguagem já pré-estabelecida.

Ou seja: o Ruy Guerra declara em uma entrevista que o espetáculo não pretendia renovar o teatro, e que oscilava, pela minha direção, entre o Teatro de Revista e o Planchonismo. E que ele considerava isso positivo, e que era essa a proposta. Mas até que ponto eu, como encenador, não deveria fazer com que minha proposta fosse um pouco mais adiante? Não deveria tentar encontrar isso dentro do que eu penso, e sobretudo dentro da proposta de um teatro político? Que se destina à reflexão da plateia para a transformação da nossa sociedade, que está fora do palco, fora da plateia, fora do teatro. Até que ponto imagens mais fortes do ponto de vista teatral não teriam sido encontradas? Interpretações mais fortes dentro do nível de exposição dos personagens ao público não deveriam ter sido pesquisadas?

Eu tenho a sensação do vazio do espetáculo não concluído. A sensação do vazio de o espetáculo não ter tido comunicação com o público, porque não houve público. A satisfação de que alguns ensaios foram assistidos por pessoas e todo mundo gostava, aplaudia em cena aberta, até. Mas os próprios aplausos em cena aberta me levavam a pensar, às vezes: será que estão aplaudindo porque estão vendo uma coisa que há muito tempo não se via, simplesmente? Ou seja, será que o espetáculo é velho, ou será que o espetáculo é novo? 
Pode ser a sensação da Valquíria de que o espetáculo é intelectual. Até que ponto esse intelectualismo realmente era uma conquista do espetáculo, era um amadurecimento meu? Ou até que ponto era resultado de uma meditação demasiadamente fria diante da realidade, e diante da peça? Que no máximo levava ao entendimento de uma série de conceitos que poderiam se desprender da forma do espetáculo, da estrutura cênica do espetáculo, mas um tipo de conceituação preso a categorias antigas.

Ou até que ponto o espetáculo era exato. E até que ponto, sei lá! Talvez tudo isso seja bobagem, e a crise venha só da paralisação do espetáculo. É possível que, apesar de tudo, fosse o meu espetáculo mais maduro. Fosse um espetáculo maduro, não importa o “meu” espetáculo maduro. Fosse um espetáculo maduro, sólido, agressivo, até. Profundamente competente, profissional no sentido de acabamento, tudo. São problemas, talvez, que eu não tenha resposta nunca.

Eu sinto a necessidade muito grande nesse momento (hoje, 18 de novembro de 1973 aqui no Rio de Janeiro, sem saber bem o que vou fazer pela frente), de me lançar a uma experiência mais total. Onde eu possa tentar trabalhar mais adiante. Em uma série de pesquisas incertas, uma série de caminhos discutíveis - isso é, não “discutíveis”. Uma série de caminhos desconhecidos para mim. Isso sem perder nunca a proposta política. Mas isso tudo é um tipo de reflexão que eu não posso deixar de fazer nesse momento.

Até que ponto talvez eu esteja pensando em demasia, nesse momento, no significado da obra de arte, que eu parei para pensar. Inclusive lendo um livro sobre estética, um livro sobre cinema, também. Que colocam problemas que eu sei, que não me são surpresas, mas que me redespertam para a necessidade de um estudo maior do próprio significado do teatro enquanto obra de arte, enquanto resultado diante de um público, enquanto reflexão sobre o significado do homem e da História. Sei lá, eu vou parar por aqui mesmo. Talvez eu continue essas observações outro dia, outra hora. Mas são coisas que eu queria falar. Eu não sei se eu falei o que eu penso, mas acho que falei boa parte do que estava na minha cabeça e que eu estava precisando vomitar, primeiro, eu vomitei agora. É isso. 


\title{
ANEXO G
}

\section{Entrevista com Mário Masetti - 29 de novembro de 2016}

\author{
Entrevistadora: Nina N. Hotimsky.
}

Nina - O foco da pesquisa é estudar a encenação do Calabar. Nos textos do Fernando Peixoto sobre Calabar, ele fala que as encenações de 1973 e de 1980 são bastante diferentes.

Masetti - Muito diferentes. Tem uma coisa primordial, no meu modo de entender, que é uma montagem carioca e uma montagem paulista. E uma montagem paulista feita pela Companhia do Othon Bastos. Que tinha um rigor de esquerda, esquerdista. E a montagem carioca, ela era extremamente libertária. Ela era extremamente livre, porque eram atores cariocas jovens, bonitos, vibrantes. Isso eu tenho certeza que contou muito na montagem do Rio. A montagem de 1980, acho que ela foi um pouco encomendada demais.

Pensando um pouco sobre o Calabar de 1973, eu lembrei de um filme que chama Trens estreitamente vigiados. É um filme tcheco. Eu lembrei porque era como eu me sentia na época. Setenta e dois, setenta e três, eu estava voltando da Europa... Eu saí tendo que sair do Brasil. Não fui exilado, nada disso, mas me recomendaram sair. E eu fui pra lá, e descobri a política, vamos dizer assim. Nesse ter que sair, e o viver lá. Tive perto dos exilados, dos organizados. E quando eu voltei eu vinha muito com essa carga pesada de necessidade do político e tudo isso, misturado com a minha adolescência tardia. Então eu fui morar no Rio de Janeiro, com um elenco desbundado, livre, libertário. Então estava assim num misto... Esse filme é isso. É um garoto que descobre o amor no mesmo momento em que ele tem que fazer uma tarefa política.

Nina - Era tudo ao mesmo tempo?

Masetti - Era tudo ao mesmo tempo. Então o título do livro do Rubem Fonseca é o ideal pra mim, é “vastas emoções e pensamentos imperfeitos”. (Risos). Lá na montagem do Rio eu vivi isso de uma maneira muito intensa. E a montagem tinha isso. Nós vamos chegar lá, eu vou te falando um pouco, e você vai ver que ela se encerra com uma festa no apartamento do Chico Buarque, ele morava na Lagoa numa cobertura, e deu uma festa pra todo o elenco, e foi um porre coletivo. Não tinha tristeza. Tinha uma sensação de dever cumprido e de alguma coisa que foi cortada, mas estávamos alegres, felizes, 
bebendo e falando: “A luta continua, vamos em frente. Sai da frente que atrás vem gente”. Acho que é um pouco essa mistura, entendeu?

Nina - É legal te escutar falar isso, porque o que eu li sobre o assunto traz aquele relato de: “investiram muito dinheiro, e todo mundo acabou mal, todo mundo quebrou...”.

Masetti - Não, não! Foi uma festa desbundante! Eu lembro que um dos integrantes da produção bebeu, e ficava andando de gatinhas. (Risos). Até num lugar perigoso, no último andar. No terraço.

Nina - Ainda bem que deu tudo certo!

Masetti - Deu tudo certo. Mas estava todo mundo... claro, tinha uma sensação de tristeza, mas tinha uma coisa de falar: "estamos iniciando nossas carreiras de uma maneira bacana, já temos uma história para contar”.

Nina - Como você foi chamado, virou diretor assistente?

Masetti - Eu fui assistente do Fernando. Eu comecei em 1967 no colégio Vocacional. E no colégio Vocacional quando você entrava para o Ensino Médio você tinha que ter uma atividade remunerada, obrigatória. Fazia parte da atividade curricular. Aí eu fui trabalhar num escritório de advocacia... mas eu era bom aluno de teatro. Meu professor de teatro era o Jorge Andrade. Eu era bom aluno, ele gostava de mim, e eu falei: "Professor, eu estou meio de saco cheio de ir pro escritório de advocacia, ficar o dia inteiro anotando recados de um advogado que não está lá”. Era até um cara bacana, o Dalmo Dallari. Mas o trabalho era chato. E eu ficava lendo e anotando recado. Aí ele falou: “O Arena está terminando o Tiradentes e vai começar uma peça que vai chamar Feira Paulista de Opinião, e eles me encomendaram um texto”. Aí ele falou com o Boal e o Boal falou “Fala pra ele vir aqui!”. Fui falar com o Boal e consegui um trabalho, e comecei a minha carreira por ali. Paralelamente eu também, o Mauricio Capovilla tinha estado lá no Colégio Vocacional fazendo um filme sobre o ensino vocacional. E eu também fiquei deslumbrado com aquelas pessoas, câmeras de filmagem, e documentaristas. Era com alunos da ECA. E falei "É isso que eu quero". Eu fiquei meio estagiando, no tempo em que eles ficaram filmando lá. E aí foi! Comecei a trabalhar no Arena, me liguei ao grupo do Arena na época - Dulce Muniz, Celso Frateschi, Denise, enfim. Hélio Muniz. Trabalhei na Feira de Opinião já como Assistente de Direção B, vamos dizer assim - porque tinha um Assistente de Direção A que era o Zanoni Ferrite, que era ator do espetáculo também, e eu era uma espécie de “faz-tudo”. E mesmo no Tiradentes eu ainda ia lá, fazia uma contrarregragem. E na Feira eu ficava tomando o 
texto, o que me permitiu ficar perto do Boal, e aí ele falou: "Você vai operar o som, o gravador do espetáculo”. Fiz a temporada. Quando terminou a temporada do Feira de Opinião estava no auge do racha do Arena. O Guarnieri estava rompendo, e o Boal estava rompendo com o Partidão. A coisa toda começou ali. O Boal montou ainda um Arturo-Ui do Brecht com o Guarnieri fazendo. E eu trabalhei nessa montagem, e logo em seguida o Arena degringolou, o Boal foi preso, o Fernando Peixoto rompeu com o Oficina. Com o Núcleo do Arena que estava indo para o Teatro São Pedro, a gente ainda fez uma montagem no Arena, uma criação coletiva, chamava Doce América, Latino América, textos de autores latino-americanos, o brasileiro era um texto do Plínio Marcos. Mas era esse grupo, Celso, Denise, tinha vindo o Antonio Pedro do Rio, que se incorporou. O Fernando saiu do Oficina e a gente convidou ele pra montar o Tambores na Noite do Brecht no Studio São Pedro, era um teatrinho que tinha lá dentro do Teatro São Pedro, no segundo andar. O Maurício Segall encampou essa montagem, vamos dizer assim, e usou o elenco e toda a equipe, inclusive o Fernando, para fazer um espetáculo sobre a Semana de Arte Moderna de 1922, chamava A Semana. E aí eu comecei a trabalhar como assistente do Fernando. Primeiro no Tambores na noite, depois no A Semana, e ainda teve um Frei Caneca do próprio Queiroz Telles, também no São Pedro. Aí eu fui embora para a França. Quando eu voltei teve O grito parado no ar, do Guarnieri, e depois o Calabar. O grito parado no ar acho que eu voltei, eu não lembro bem, eu fiz uma volta meio pseudo-clandestina. Não é que eu não podia voltar para o Brasil. Mas corria risco de ficar uns dias lá, tendo que responder coisas. A primeira vez eu vim, aconteceu, a segunda vez não aconteceu nada, aí eu falei: "Vou começar a voltar paulatinamente”. Voltei, e aí tinha o Calabar no Rio. Eu lembro que foi bacana que o Fernando Torres falava: “Trazer um assistente de São Paulo! Que luxo! Para quê?”. E o Fernando insistiu: “Você vai gostar, vai ver como é importante!”. E depois os dois Fernandos escreveram a meu respeito, elogiando meu trabalho, me senti super contente. Acho que foi quando eu estreei a minha primeira direção. Num artigo que chama “À guisa de discurso de formatura”.

Nina - Muito legal você contar de tudo isso que você fez antes. Porque uma das coisas que eu fico curiosa é em que medida que essa encenação de Calabar veio dos musicais políticos dos anos 1960, do Arena, do Opinião, até do Oficina, e em que medida romperam. Qual é a sua sensação a respeito disso? 
Masetti - No caso do Fernando Peixoto não teve rompimento nenhum. O Fernando era um comunista assim, militante do Partido. Vou te contar uma história pitoresca dos testes do Calabar. Foi uma brincadeira, mas revela um pouco o que era o Fernando Peixoto. Uma atriz fez o teste, e quando terminou ela falou assim: "Vou ficar esse final de semana rezando pra Deus para poder entrar no elenco”. Aí a gente se reuniu, e ela era uma boa atriz. E ela fez o espetáculo. Mas enfim. Ele olhou para mim e falou assim: “A gente tem que provar a inexistência de Deus! Esse é o melhor momento!”. Falei: “Não acredito Fernando, que você está falando isso”. E ele sustentou como verdade por um bom tempo, e depois deu uma risadinha assim: “Ok, vamos deixar barato”.

Nina - Apesar de Deus ela pode fazer a peça.

Masetti - Exatamente - ou da inexistência de Deus. Vamos considerar que não foi Ele que deu esse apoio! Mas enfim, o Fernando tinha esse rigor. Os trabalhos anteriores tinham o que eu chamaria de um observador ideológico. Não sei se é uma boa palavra. Mas ia gente do Partido assistir tanto $O$ grito parado no ar como A semana como $O$ Frei Caneca, fazer uma avaliação política. Da importância política daquele espetáculo do ponto de vista do PCB. E ele ficou muito ligado ao Guarnieri. E ficou muito ligado ao Othon e à Martha. A Companhia do Othon Bastos (com Um grito parado no ar, depois Murro em ponta de faca e Ponto de Partida) substituiu de certa forma o Arena. Enquanto teatro. E era uma loucura. Agora, tinha esse rigor, mas tinha e não tinha, porque também o Murro em ponta de faca era do Boal, enfim. E o Boal rompeu mesmo com o Partido, quando o Marighella fez o famoso artigo quando ele se desliga do Partido. Eu não me lembro agora o título do artigo, mas quando ele se liga à luta armada.

Nina - Falando em Marighella, uma das coisas que se diz sobre o personagem Calabar é que havia uma associação com outro guerrilheiro, o Lamarca. Em que medida isso era uma associação direta mesmo, ou não?

Masetti - Não sei se do ponto de vista dos autores, mas do Fernando Peixoto eu acho difícil. O Fernando era mais ligado ao Partidão mesmo, que era pela não violência. Agora, tudo isso era muito misturado, porque também era o início de tudo. Vastas emoções e pensamentos imperfeitos de novo, não é? Mas você lê as coisas do Fernando, ele era rigoroso na coisa da montagem. Não estou emitindo juízo de valor, mas isso transformava o espetáculo numa coisa mais cartesiana. Mais exata, vamos falar assim. 
Nina - E eu tenho a impressão de que isso era uma coisa que o Chico Buarque queria também, porque em algumas entrevistas do Chico ele fala como o Roda Viva foi uma super experiência, mas foi caótico.

Masetti - Era uma porralouquice! Que era a questão do Oficina e do Arena, não é? Tinha um pouco isso, nesse momento. E tinha o Ruy Guerra! O texto ainda não estava totalmente escrito. Eu lembro que quando eu cheguei no Rio eu acompanhei o final da escrita, fui algumas vezes na casa do Chico com o Fernando. E eles estavam ainda elaborando os finais, estavam tentando ainda mexer, talvez até a pedido do Fernando, não me lembro. Eu vi o Chico compondo uma música.

Nina - Nossa, morri!

Masetti - Morri mesmo! Foi muito legal!

Nina - Você lembra qual música era?

Masetti - (Canta) "Você vai me seguir” ... Que é uma música que, como o Calabar não estreou, ele usou na Gota d'Água logo em seguida. Espera: era outra a música que também foi usada no Gota d’Água. (Canta): "Ninguém sabe nada, ninguém viu nada, ninguém fez nada. Ninguém é culpado, bichos de estimação nesse jardim”. A canção chama Cuidado no Calabar, e na Gota d’Água tem um outro nome: Basta um dia. (Canta): "Pra mim, basta um dia”. É a mesma música!

Nina - É a mesma música?

Masetti - Sim. A canção que tem no Calabar, Cuidado, você pode cantar com a melodia do Basta um dia: vai ver que dá certinho.

Nina - Que loucura! É, que também...

Masetti - Não vai jogar fora!

Nina - E você assistiu Gota d'Água?

Masetti - Assisti.

Nina - Você lembra um pouco?

Masetti - Muito pouco, eu assisti uma vez como espectador. Aqui, no teatro Aquarius, não é? Por que? Foi por uma outra circunstância. Eu fui fundador, junto com outras pessoas, do Teatro Lira Paulistana. Que foi um boom da música alternativa paulistana, mas que surgiu como um teatro. E um dos donos do Lira Paulistana era músico da Gota d’Água e conhecia o Cláudio Mamberti, que era ator e trabalhava comigo, e a gente montou os dois primeiros espetáculos do Lira Paulistana por conta desse relacionamento. Nossa, como as coisas se ligam, eu não tinha pensado nisso. O Gordo 
chama Wilson Souto. É um cara importante na música, ele foi presidente de uma gravadora depois, que gravou muita coisa do grupo Rumo, Premê, todo esse pessoal surgiu no Lira Paulistana. E o Lira surgiu com uma remontagem do Tambores na Noite dirigida por mim com o Cláudio Mamberti como um dos atores. Cláudio Mamberti, Dulce Muniz, Cacá Rossetti, olha o elenco! Edith Siqueira. Era uma loucura mesmo.

Nina - E o que você lembra da encenação do Gota d'Água?

Masetti - Eu lembro da Bibi, era uma coisa antológica realmente. E ela era a mulher do Paulo Pontes. Era muito forte. A Bibi Ferreira não era uma mulher de esquerda. Mas o Paulo Pontes era. E ela fez com uma verdade, eu lembro que era muito bacana. Ela botou uma coisa Passionária, que talvez seja o comunismo mais bonito que exista. Que a Passionária é aquela líder espanhola, da Revolução Espanhola, Dolores. Tinha a coisa da paixão junto com a ideologia. E tinha essa música! Dava vontade de levantar e: "Rá Rá! Essa música é do Calabar! O cara se plagiou!”.

Eu acho que a Gota d’Água não foi colocada no mercado como um espetáculo político. Era um grande musical, uma adaptação da Medéia, enfim. Acho que não tinha essa veia de falar "o espetáculo ideológico, que quer imprimir uma ideologia”. Com a força que o Arena e o Oficina tinham, ou a primeira peça do Chico, enfim. Acho que não era o ponto de venda, vamos dizer assim, do espetáculo.

Nina - E o Calabar, se tivesse estreado: era claramente político?

Masetti - Eu acho que a cabeça do Fernando Torres e da Fernanda, no fundo... era a produtora deles. Comprou essa barra. Apesar de que a Fernanda estava fazendo concomitante (enquanto a gente estava ensaiando) um vaudeville no teatro Maison de France que não tinha nada assim. Era O amante de Madame Vidal. Mas com Calabar tinha um compromisso de se fazer um espetáculo político. Ela tinha essa força. Um elenco muito grande. Mas acho que nem teve tempo de se trabalhar isso enquanto lançamento. Porque também era um espetáculo que acho que as pessoas estavam sabendo que não ia acontecer. Eu tenho essa impressão, ao mesmo tempo.

Nina - Isso é outra discussão: se fala mais sobre a censura do Calabar do que sobre a peça Calabar.

Masetti - Isso! Isso!

Nina - E uma das coisas que se diz é que o Calabar foi importante porque, mesmo sabendo que ia ser censurado, o Chico brigou. Como figura pública e judicialmente, não é? 


\section{Masetti - Sim!}

Nina - E como foi isso para o elenco, pra quem estava ensaiando?

Masetti - Todo o elenco comprou essa barra. Com exceção de uma atriz. Inclusive criou-se um certo estranhamento. O fato de ela não estar tão empenhada quanto todas as outras pessoas que estavam no elenco. O elenco de Calabar, o elenco de apoio que a gente chamava de arraia-miúda (porque tem um trecho na peça que usa essa expressão) era um elenco ideologicamente muito forte. Resultou em gente bastante participativa, depois. Nas questões da política.

Nina - Você mencionou os testes. Mas teve gente que entrou e que já trabalhava junto, que já era alinhada politicamente?

Masetti - Os papéis mais centrais sim. Mas mesmo nos testes tinha um pouco essa preocupação de pegar pessoas preocupadas com essa questão.

Nina - Entendi. De acordo com o que estudei, era rara a figura do coreógrafo naquela época. E Calabar tinha um coreógrafo. Você lembra como era isso?

Masetti - Em Calabar eu ganhei o título de diretor assistente para esse coreógrafo poder também ganhar o título. Porque ele era muito bom. Era o Zdenek Hampl. Ele vinha da “Lanterna Mágica de Praga”. Que era quase um Cirque du Soleil da época, era uma coisa linda! Ele era o coreógrafo e diretor assistente. O trabalho dele era quase que de direção. Tinha muita música, e o trabalho de... esse cara era um louco. Mas um louco tão bacana! Ele saiu da "Lanterna Mágica”, ele se apaixonou por uma bailarina brasileira, Verinha, casou, e ficou no Rio. E ele era quase cego. Ele via vultos. Pra um coreógrafo isso é uma loucura! E ele fazia coisas maravilhosas. Desde números de dança comuns até... Como é que eu vou te falar? Movimentação de guerrilha no palco. Uns caras pendurados. O cenário era basicamente duas esteiras de porto. Sabe umas cordas que pegam os contêiners? E eram essas cordas esticadas e as pessoas escalavam, pulavam de corda para corda, tinha uma movimentação ali. Agora, na verdade o espetáculo não estava totalmente pronto quando foi proibido. E para a gente filmar eu lembro que a gente fez um tour du force de falar: "Vamos terminar o espetáculo!". Então eu fiquei meio cuidando de toda a figuração, disso eu lembro bem, e dos movimentos de cena, enquanto o Fernando ensaiava com os atores principais, para a gente ter um espetáculo pronto. Enfim, estava semipronto. Mas faltava, ainda. E a gente correu-correu-correu para a gente poder filmar. Vieram para o Rio dois amigões que filmavam na época, o Hermanno Penna e o Aloysio Raulino, são dois diretores de 
cinema independente bem importantes. E lá do Rio a Rose la Creta coordenou um pouco essa filmagem.

Nina - A filmagem aconteceu, então?

Masetti - Ela não aconteceu. A gente posicionou; no dia em que ia filmar o ensaio geral o diretor do teatro João Caetano proibiu a entrada de câmeras, para não ter registro realmente nenhum. Eu não sei, talvez a Rose possa dizer isso, não sei se ela fez depoimentos do Chico, do Ruy. Teriam sido feitos fora do ambiente do ensaio. O Aloysio Raulino me disse que foi filmar um depoimento do Chico Buarque. Nunca vi isso, nunca ouvi falar; falei com o Chico e ele não lembra. Então acho que vai entrando para essa coisa mitificada.

Nina - No prefácio, em um dos textos do Fernando, ele fala que houve uma gravação, mas pelo que entendi foi uma gravação de voz.

Masetti - Comigo.

Nina - Uma conversa de vocês dois?

Masetti - Sim. Eu daria tudo para ter essa fita!

Nina - Você não tem?

Masetti - O Fernando tinha essa fita. No final da vida dele eu perdi um pouco o contato. Ele estava doente. Quando ele morreu a Anna de Hollanda, que foi casada com ele, até falou: “Tem muitos materiais do Fernando”. Vale a pena você ligar para ela. Se eles conseguiram catalogar todo esse material do Fernando... ele tinha livro até no banheiro! Ele era um louco com a coisa de ler.

Nina - Achar essa gravação ia ser lindo!

Masetti - Nossa, seria! Eu lembro do dia que a gente começou a gravar. E foi muito bacana mesmo, porque o Fernando tinha aquelas coisas do Berliner Ensemble de querer fazer Model Book, fotografar o espetáculo - isso em outros espetáculos a gente fez. Fotografar o espetáculo minuto por minuto. E ele escrever, fazer um estudo. A gravação era um pouco em função disso.

Nina - O cenário de Calabar você diz que remetia a um porto. Você se lembra dos figurinos?

Masetti - Lembra um pouco de camponeses, e povo do Recife. Com a chegada dos holandeses a coisa virava um Teatro de Revista mesmo. Muito próximo do Teatro de Revista. Porque era o discurso otimista do Mauricio de Nassau, era a festa do boi 
voador, tudo isso. Então era esses camponeses com uma releitura colorida dos tempos lusitanos, assim, que eram mais sombrios.

Nina - Tinha um boi que voava, mesmo?

Masetti - Tinha um boi que voava. Era um boizão de madeira forrado com pele de boi. E no meio do caminho tinha umas cordas, uns cordéis. Ele abria a barriga, caía confete... Espetáculão popular.

Nina - Sobre a questão do popular. Se o espetáculo tivesse estreado você acha que teria sido acessível para quem não era classe média intelectualizada assistir? Ou era muito difícil...?

Masetti - Acho que sim, acho que sim. Do ponto de vista da percepção do espetáculo? Ou de pagar o ingresso?

Nina - A percepção e o preço.

Masetti - Ah, acho que sim, acho que seria acessível. Eu lembro que se falava muito na época de se fazer espetáculos a preço popular, e era o Teatro João Caetano, que era um teatro enorme. Então permitia que os ingressos fossem mais baratos.

Nina - E do ponto de vista da compreensão, você acha que as discussões estavam claras?

Masetti - É, o Fernando tinha uma coisa muito, até aprendi muito isso com ele, eu defino até hoje. Ele usava a última tabela que o Brecht escreveu para os seus atores. A tabela que fica no teatro. A tabela era um meio de comunicação de todo mundo que trabalhava num determinado espetáculo, tinha uma tabela que a pessoa tinha que ler quando ele chegasse no teatro. Então o diretor punha recados, o assistente de direção punha correções, o contrarregra punha punições... Era muito bom. "Nina chegou atrasada dia tal 20 minutos”. (Risos). E às vezes tinha punição mesmo. Enfim, era uma coisa muito respeitada. Ela era coordenada pelo contrarregra. E o Brecht escreveu uma última tabela para um espetáculo que o Berliner Ensemble ia fazer num teatro de Paris. O alemão é uma língua difícil para os franceses, e ele escreve que os espectadores tinham que perceber todas as intenções através dos gestos e das reações dos atores. E o Fernando tinha isso muito presente mesmo. Eu lembro que a gente fazia ensaios mudos. Era bacana isso! Com a obrigação de o ator conseguir expressar o que texto estava dizendo. Então tinha isso muito claro, nos gestuais e tudo.

A própria linguagem da Revista, não é? Acho que nisso tem uma contribuição minha, eu já estava começando com os meus trabalhos acadêmicos, que eram sobre a ideia do 
ator cômico e popular brasileiro. E então tinha toda essa coisa dos gestos largos, do quase circense. E eu lembro que o Fernando incorporou muito isso nesse espetáculo. A gente trabalhou bastante isso, sobretudo com essa arraia-miúda.

Nina - Uma coralidade que era engraçada?

Masetti - Isso!

Nina - E as canções? É engraçado, porque algumas canções também são para fazer rir... Masetti - Sim.

Nina - E ao mesmo tempo tem algumas canções muito sérias e dramáticas, não é?

Masetti - É. Tinha os personagens, tinha um pouco esse caminho. O Calabar não existia. Então teve até uma brincadeira... em algum momento o Zé Wilker teria ligado para o Chico Buarque e falando: “Nossa, eu quero fazer o Calabar! Esse personagem para mim é....”. E o Chico teria dito “Wilker, ele não aparece”. (Risos). Mas o fato de ele não aparecer fazia o personagem da Barbara ter angústias, instrospecções, vamos dizer assim, que a Anna de Amsterdã não tinha. A Anna era mais jogada para fora, era a coisa mais cabaré. Então tinha um pouco essa duplicidade no espetáculo.

Nina - A Anna chega a falar isso, "Eu queria ainda sentir como você sente, mas já faz muito tempo que eu não sei o que é isso”...

Masetti - Isso! Isso! Acho que tinha até um gestual assim, que ela punha a mão no sexo falando: “Pra mim o que importa é dinheiro aqui e rapidez!”. Enfim, fazia uma brincadeira com isso. E os atores figurantes reagiam conforme as duas que conduziam o espetáculo, vamos dizer assim. Uma coisa muito bacana: Lutero Luís, Hélio Ary, e o Antonio Ganzarolli, que estavam na montagem, são atores que vêm do Teatro de Revista. O Lutero eu não sei, mas poderia ter vindo do Teatro de Revista tranquilamente. Eles tinham a comédia no dia-a-dia maravilhosamente. E o Hélio era papel principal, ele fazia o Mathias de Albuquerque e o Nassau.

Nina -Tem um texto do Fernando falando que era essencial para a montagem que o Mathias e o Nassau fossem o mesmo ator. Por quê?

Masetti - Porque ele pegava esse rompimento. O humor dos tempos sombrios era um humor em cima das doenças venéreas, dos cocôs. E ele voltava um ator cômico cômico não, um ator de Teatro de Revista - fazendo o Mauricio de Nassau. E o Lutero fazia o padre que atravessa os dois momentos. Eu lembro que tinha no texto um momento em que alguém falava: “Descobri a cura da Gonorréia!”. Era só mascar cana! 
O Lutero se agarrava como padre com um monte de cana e saía de cena. A plateia... a plateia não, mas a gente vinha abaixo!

Nina - Eu estranhei que nesse momento do texto a rubrica indica que o Frei maliciosamente recuse a cana. Mas então na montagem ele pegava a cana!

Masetti - Agarrava um monte de cana e ia saindo de mansinho!

Nina - Fortalece a piada!

Masetti - Claro!

Nina -Uma coisa que observo no texto é como tem alusões diretas a problemas políticos da época. Por exemplo, a menção à tortura. É por isso que vocês achavam que não ia estrear?

Masetti - Eu não vou saber te dizer. Eu acho que talvez eles tenham tentado negociações. A Fernanda Montenegro, vamos combinar, era e é ainda “a” atriz brasileira. Então, se tivesse alguma possibilidade ali do Fernando Torres negociar, alguma abertura, a possibilidade de trocar trechos pontuais, ele iria tentar isso. Ele iria fazer. Eu lembro que o Fernando falava muito sobre isso, "talvez a gente vá ter que conceder em algum momento algumas coisas para poder fazer o espetáculo acontecer. A gente já está prevendo isso. Mas enquanto não tiver nada nós vamos fazer o espetáculo que a gente quer fazer, que a gente gostaria de fazer”.

Nina - E o que eu entendi é que a censura nem chegou a assistir?

Masetti - Não. E naquela época tinha Paulo Pontes, Guarnieri, Vianinha ... Cada um fez a sua peça naquele momento. O Guarnieri fez mais de uma. O Guarnieri partiu para uma coisa do “Teatro de Ocasião”, que ele chamou. Ele fez O Botequim, Ponto de Partida, Um grito parado no ar... são peças que têm uma força política! O Paulo Pontes fez a Gota d'Água e o Vianinha fez o Rasga Coração, é tudo mais ou menos ali, não é? Anos 1970. E todos tem uma grandiosidade que é a do musical. Um grito parado no ar não. Mas O Guarnieri estava muito ligado ao Toquinho. O Botequim é um musical com músicas do Toquinho. A atriz que fazia era a Marlene, vedete: cantora das multidões! A Bibi Ferreira também... E o Rasga Coração também tinha essa grandiosidade. Guarnieri fez uma peça antes também, chamada Marta Saré. Foi produção do Fernando Torres, da Beatriz Segall e era com Fernanda Montenegro, Beatriz Segall... Foi a peça que inaugurou o Teatro São Pedro. Num momento terrível em que o Maurício Segall, dono do teatro, estava preso, torturado. E a Beatriz Segall, naquele momento, aguentando e segurando os piores rojões do mundo ali. Com o 
marido preso e ela resistindo, com o teatro ali. Justiça seja feita! Hoje em dia ela está com noventa anos. Eu a encontrei outro dia, ela ficou muito emocionada. Eu toquei um pouco nesses assuntos. A vida leva a gente por uns caminhos... Ela rompeu com o Maurício, enfim. Talvez tenha sido mais Segall que ele. Do ponto de vista de ser uma pessoa de uma nobreza, assim. Mas enfim, eu não saberia emitir um juízo de valor. Eu sei que naquela época ela sofreu muito e foi brava. Muito corajosa mesmo.

"Vastas emoções e pensamentos imperfeitos": era bem isso mesmo. Eu tenho uma adaptação para o cinema de Um Grito Parado no Ar em que eu misturo um pouco a minha vida pessoal com a peça. Um Grito Parado no Ar também tem esse lado... Trens estreitamente vigiados. E eu me sentia um garoto ali, 1972, 73, nessa época. Nossa! O mundo estava fervilhando, tudo acontecendo, os primeiros amores, e as primeiras ações mais sérias, os primeiros comprometimentos com a esquerda e tudo isso. "O Boal rompeu com o Partidão! O Boal agora apoia o Marighella! Que demais!”. O roteiro que eu escrevi de Um Grito Parado no Ar tem isso. Gostaria muito de filmar, um dia. Para falar dessa época. Acho que seria uma maneira justa de contar a história do Grito. Porque eu misturo coisas que eu vi enquanto Um Grito estava acontecendo, e estavam acontecendo outras coisas. Nem sei se é um roteiro bom, hoje em dia. Teria que ser revisto. Mas na época foi escrito um pouco com esse sentimento. Cenas que eu vi enquanto a gente estava fazendo Um Grito. Eu lembro que a gente ensaiava no teatro da Aliança Francesa. Um dia a gente estava num bar, chovia, e de repente do outro lado da rua para um carro da polícia, um carro placa fria. E a gente ali olhando, a chuva, e sai um garoto debaixo de porrada, jogam ele dentro do carro, esse camburão sai e de repente vem o pai e a mãe do garoto chorando, olhando um para o outro. "O que a gente faz? O que aconteceu?”. E a gente olhando e não podendo fazer nada, quietos. E em algum momento alguém quis ir até lá, mas alguém falou: "Fica aqui senão você vai se ferrar”. E isso tudo a gente estava vivendo enquanto a gente estava fazendo uma peça. Então mistura tudo. O garoto que estava vendo tudo aquilo, vivendo tudo aquilo, num momento... "Uau. Puta, que mundo! E eu estou aqui no meio desse caldeirão, tentando entender, ao mesmo tempo em que as coisas estão acontecendo”. Eu acho que eu sou o que eu sou um pouco porque as coisas aconteceram desse jeito, não é? Bacana.

Nina - Como você se sentia em relação à questão da luta armada?

Masetti - O Fernando falava muito contra. Mas ao mesmo tempo montou a peça do Boal, Murro em ponta de faca. Num momento que o Boal já estava exilado. Mas isso 
tudo eu ponho por conta do "Vastas emoções e pensamentos imperfeitos”. O Guarnieri também - era do Partidão, mas ficou atônito com a morte do Vladimir Herzog. Que era um cara do Partido, mas que foi uma morte como se tivesse sido o pior guerrilheiro do mundo. Que não era, mas enfim. Então, quer dizer, a direita vinha também com atitudes assim, que faziam as pessoas perderem o rebolado. Agora: eu, garotão, jovem, vibrava .... No tempo em que eu passei na França tive contato com o pessoal exilado de grupos mais à esquerda do que o Partidão. A ALN até teve na Europa uma tendência Leninista, que talvez tentasse aproximar mais as ideias do Partido de uma possível versão de esquerda guerrilheira, vamos dizer assim.

Nina - Tenho a impressão de que, na dramaturgia de Calabar, tem uma discussão ampla sobre se vale a pena lutar, ou como não desistir de lutar, que talvez dissesse respeito a todos que resistiam ao Regime Civil-Militar. E não apenas à guerrilha.

Masetti - Isso. Claro, Vence na vida quem diz sim, não é? Acho que sim. Cobra de vidro também era uma música bem: "Você pode me fazer em mil pedaços que eu renasço".

Nina - Como era trabalhada a música no espetáculo? Tinha uma sonoplastia todo o tempo, ou a música se fazia presente apenas durante as canções?

Masetti - Tinha uma banda de mão cheia no palco! Dory Caymmi, Danilo Caymmi na flauta, Tenório Júnior (que morreu como desaparecido na Argentina, e era um pianista maravilhoso), tinha um menino que cantava no "Boca Livre”, também um super instrumentista. Esses músicos estavam o dia inteiro tocando com a gente. Os arranjos das canções foram feitos pelo Edu Lobo, e o Dori fez os arranjos da banda ao vivo - que eram vários. O Boi voador era ao vivo.

Nina - O Dori Caymmi frequentava os ensaios todos os dias?

Mario - Direto, ele tocava no espetáculo. Ele me chamava de boi voador (Risos).

Nina - Os cantores usavam microfone?

Masetti - Tinha microfone descendo do urdimento. Isso, só nos últimos ensaios. Mas era para ser sonorizado desse jeito.

Nina - Ainda sobre a sonoplastia: havia momentos em que a música não dizia respeito a nenhuma das canções, e sim acompanhava a ação? Havia outras composições feitas para sonorização de cenas?

Masetti - Sim. Música incidental, efeitos, sim. 
Nina - O piano era usado para fortalecer a comicidade? Havia alguma proximidade com o estilo do circo-teatro?

Masetti - Não. Comentários, assim? Não, não.

Nina - Como era o trabalho com o canto dos atores?

Masetti - Recentemente eu fiz um musical chamado Um musical na contramão. Trabalhei com atores cantando: eu não compactuo com essa coisa do belting, do jeito americano de cantar. No Calabar os atores passaram por um crivo muito rígido de testes, que foram feitos no Rio e em São Paulo, para pegar gente que cantava muito bem.

Nina - Então o canto não foi uma dificuldade?

Masetti - Não, pelo contrário, eram momentos vibrantes do espetáculo.

Nina - E a dança também era tranquila para os atores?

Masetti - Tranquilo.

Nina - E qual era a principal preocupação da direção?

Masetti - A interpretação: o que a gente chamava de "movimento das massas”. (Risos).

Nina - Como era isso?

Masetti - Eram os deslocamentos das massas. Havia um grupo: "Sai todo mundo para a direita! Vem para a frente!”. Havia uns movimentos muito legais! Eu lembro que eu dirigia - dirigia, que pretensão - eu era um assistente de direção. Eu ficava dentro do palco. E o Fernando ficava na plateia. A gente tinha um sistema de comunicação precário, porém eficiente: eu ficava meio olhando ele, e ele me dava dicas. E a gente ia mexendo um pouco, para ele sentir essas experiências. De como os atores estavam se movimentando, como ficava melhor ou pior...

Nina - Ele falava: “Vai todo mundo para lá!”, e você ia junto com o pessoal?

Masetti - Eu que sugeria. E ele: “Não, não! Volta, volta!”.

Nina - Isso é curioso. Calabar era uma superprodução, com muitos atores no palco basta olhar a ficha técnica. Mas quando você lê a dramaturgia, o coro aparece algumas vezes - não o tempo inteiro...

Masetti - Ah não, tinha o tempo todo. Não tinha coxia! O espetáculo era demarcado pela luz. Então os atores estavam praticamente o tempo todo em cena!

Nina - E nas cenas da dramaturgia em que acontecem diálogos entre dois atores?

Masetti - Ah, tem muitos.

Nina - E nesses momentos, o que o coro fazia? 
Masetti - Olhavam a cena, serviam a cena. Eu tinha acabado de chegar da França. Eu estagiei na França com a Ariane Mnouchkine num espetáculo que ela fez sobre a Revolução Francesa, 1789. E ela estava montando um outro espetáculo quando eu efetivamente estive lá.

Nina - Então você tinha presenciado um trabalho que retratava as massas, também?

Masetti - Não, e de atores que ficavam a serviço do espetáculo. Então ficavam fora de cena, mas por exemplo: eu lembro que tinha um momento em que um personagem precisava de uma pena de galinha para escrever. Aparecia uma mão com uma pena de galinha, o cara pegava no ar! Isso me fascinava muito. Esse tipo de atitude, de ter os atores ali: quando você está fora de cena você está a serviço da cena.

Nina - Muito legal! Porque é se servir mesmo do fato de ter muitos atores para um trabalho.

Masetti - Exatamente. O grupo! A função do grupo é isso.

Nina - Sim. Então em Calabar eles ficavam por lá, assistiam, e às vezes intervinham de alguma maneira?

Masetti - O coro tinha várias funções. Cantava... "Cala a boca, Bárbara”. Havia uma coisa meio “anjinho - diabinho”, brincadeiras. A gente falava: “Agora é anjinho, está dando conselho. Agora é diabinho, está falando ‘vai lá e se ferra!’”.

Nina - Esse dado do coro faz muita diferença! Quando você pensa que eram quase trinta atores cantando “Cala a boca!” para uma mulher sozinha, fica muito mais forte.

Masetti - Claro! E com a atitude: “Cala a boca, Bárbara, você vai se dar mal!”.

Nina - É muito mais interessante teatralmente, não é?

Masetti - Sim!

Nina - E tinha intervalo? Divisão em atos?

Masetti - Tinha.

Nina - Vocês faziam algo durante o intervalo?

Masetti - A gente correu o espetáculo muito poucas vezes. Se ia ter alguma coisa, acho que nunca falamos a respeito. Não deu tempo.

Nina - O Fernando Peixoto escreveu que nos últimos ensaios gerais tinha até menino vendendo doce.

Masetti - Verdade.

Nina - Então já havia gente assistindo?

Masetti - Muita gente! 
Nina - Como era isso de deixar pessoas entrarem para assistir?

Masetti - Ah, vinha e entrava por trás, por baixo do pano, do jeito que a gente entrava no circo quando era menininho! Era bem isso. Eu lembro que eu levei umas dez pessoas, uns amigos da França que estavam no Rio. Os caras entraram como técnicos das roldanas do não-sei-o-quê do pano de fundo! Eu falava: "São os técnicos que vieram, chegaram da França hoje para arrumar”...

Nina - A roldana da peça! (Risos).

Masetti - A rebimboca da parafuseta! Lotou, lotou. E os meninos da Praça Tiradentes vinham vender amendoim. O Fernando exagerou um pouco, também. Não era casa cheia, mas tinha muita gente. Tinha o pessoal da equipe do filme, que era bastante gente.

Nina - Acho que essa imagem que o Fernando Peixoto descreve, de o pessoal vendendo doce, tem a ver com aquilo que a gente fala quando está em cartaz: "Se aparece pipoqueiro na porta é bom sinal!”.

Masetti - Claro. Exatamente. Ia acontecer! Que o espetáculo ia acontecer não tinha a menor dúvida. Tanto que eles ficaram com medo de que fosse um puta sucesso! Medo de que ia derrubar as expectativas da repressão de manter a coisa...

Nina - Em ordem?

Masetti - Em ordem. Deixa eu te mostrar uma foto que eu tenho! (Masetti mostra a foto do elenco completo. Aponta os artistas e comenta). Hélio Eichbauer, um super cenógrafo! Rosa Magalhães, figurinista, que está hoje em dia nas escolas de samba. Flávio Santiago, que é um ator curinga do Fernando.

Nina - Ele fez o Roda Viva também, não é?

Masetti - O Flávio fez. E fez o Teatro Oficina todo. Imara Reis, que é aquela menina que eu falei que você podia eventualmente conversar. Eu - nossa senhora! (Risos). Anselmo Vasconcelos, é um ator comediante do Rio. Perfeito Fortuna, que fez depois o Circo Voador. Nina di Pádua, também uma atriz maravilhosa. Essas aqui viraram Frenéticas, depois. Esse elenco, você vê, todo mundo meio na flor da idade! Eu lembro que eu ia buscar os atores na praia. Vinham de biquíni e areia. "Não acredito que vocês vão ensaiar com areia no corpo!”. “Ah Masetti, você é um careta! Paulista!”. A coisa rolava assim. Mas muito bom, era uma delícia! 